TECHNOLOGY, SAFETY, AND COSTS OF DECOMMISSIONING A REFERENCE NUCLEAR FUEL REPROCESSING PLANT.

Battelle Pacific Northwest Laboratory for U. S. Nuclear Regulatory Commission 


\section{NOTICE}

This report was prepared as an account of work sponsored by the United States Government. Neither the United States nor the United States Nuclear Regulatory Commission, nor any of their employees, nor any of their contractors, subcontractors, or their employees, makes any warranty, express or implied, nor assumes any legal liability or responsibility for the accuracy, completeness or usefulness of any information, apparatus, product or process disclosed, nor represents that its use would not infringe privately owned rights.

Available from

National Technical Information Service

Springfield, Virginia 22161

Price: Printed Copy $\$ 12.50$; Microfiche $\$ 3.00$

The price of this document for requesters outside

of the North American Continent can be obtained

from the National Technical Information Service. 


\section{DISCLAIMER}

This report was prepared as an account of work sponsored by an agency of the United States Government. Neither the United States Government nor any agency Thereof, nor any of their employees, makes any warranty, express or implied, or assumes any legal liability or responsibility for the accuracy, completeness, or usefulness of any information, apparatus, product, or process disclosed, or represents that its use would not infringe privately owned rights. Reference herein to any specific commercial product, process, or service by trade name, trademark, manufacturer, or otherwise does not necessarily constitute or imply its endorsement, recommendation, or favoring by the United States Government or any agency thereof. The views and opinions of authors expressed herein do not necessarily state or reflect those of the United States Government or any agency thereof. 


\section{DISCLAIMER}

Portions of this document may be illegible in electronic image products. Images are produced from the best available original document. 


\section{TECHNOLOGY, SAFETY, AND COSTS OF DECOMMISSIONING A REFERENCE NUCLEAR FUEL REPROCESSING PLANT}

K. J. Schneider and C. E. Jenkins, Study Coordinators and
/ R. E. Rhoads
J. Mishima
P. J. Pelto
L. P. Williams
R. I. Smith
E. C. Watson
I. F. Nemec
G. H. Winson
J. F. Johnson
E. S. Murphy

Manuscript Completed: September 1977

Date Published: October 1977

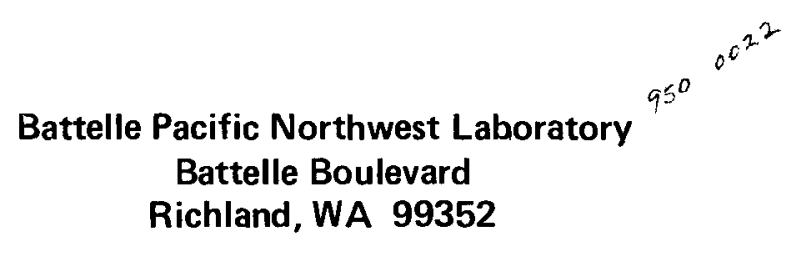

Prepared for

Division of Engineering Standards

Office of Standards Development

U. S. Nuclear Regulatory Commission

Under Contract No. EY-76-C-06-1830 


\section{STUDY CONTRIBUTORS}

Study Coordinators

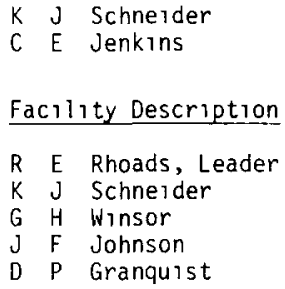

Site Description

K J Schneider, Leader

D A Waite

L. D Williams

E C Watson

$G \quad R$ Hoenes

Decommissioning Logic and Study Approach

C $E$ Jenkins, Leader

$K$ J Schneider

Decommissioning Criteria

E C Watson, Leader

L D Wil11ams

$\mathrm{J} P$ Corley

$G$ R Hoenes

W D McCormack

D A Waite

\section{Dismantlement Plans/Procedures/Costs}

R E Rhoads, Leader

J F Nemec (a), Leader

E S Murphy

$J F$ Johnson

$G$ Wunsor

C E Jenkins

$J C$ Allen

\section{Layaway Plans/Procedures/Costs}

R E Rhoads, Leader

J F Nemec $(\dot{a})$, Leader

E S Murphy

C E Jenkins

$J F$ Johnson

$G$ H Wrnsor

$\mathrm{J} \mathrm{L}$ Buelt

Protective Storage Plans/Procedures/Costs

$R$ E Rhoads, Leader

C E Jenkins,

J F Nemec(a)

E S Murphy

J $F$ Johnson

$G$ H Winsor

$J$ L Bue1t
Safety Assessments

C E Jenkins, Leader

P J Pelto, Leader

J Mishima

E S Murphy

$G$ R Hoenes

D A Warte

\section{Alternative Comparisons}

R I Smith, Leader

$K$ J Schneider

C E Jenkins

$\mathrm{J} R$ roung

Regulatory Analysis

L D Williams, Leader

L A Carter

R L Gilchrist

Safeguards Analysis

R J Brouns, Leader

$L$ D Williams

M G Hartman

\section{Financial Alternatives}

$P$ L Hendrickson, Leader

$R$ I Smith

Design Considerations

$K$ J Schneider, Leader

E S Murphy

J F Johnson

$G$ Winsor

Glossary

G J Konzek, Leader

PNL Reviewers and Advisors

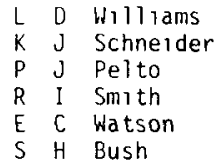

Non-PNL Reviewers

NRC Staff

J A Greene, Vitro

J W Toombs, Vitro

A $L$ Ayers, AGNS

$R$ E Brooksbank, ORNL

(a) Associated with United Nuclear Industries, Inc 
FOREWORD

by

NUCLEAR REGULATORY COMMISSION STAFF

The NRC staff is in the process of reappraising its regulatory position relative to the decommissioning of nuclear facilities. As part of this activity, NRC has initiated or will initiate several studies through technical assistance contracts. These contracts are being undertaken to develop specific background information to support the preparation of new standards covering decommissioning.

These studies will describe decommissioning alternatives and will evaluate the safety and costs associated with them. The plan is to cover all major types of nuclear facilities in the work conducted over the next several years. Separate reports will be prepared as the studies of the various facilities are completed.

Current plans include studies of decommissioning of light water reactors (LWR's) and their associated fuel cycle facilities by Battelle, Pacific Northwest Laboratories. In general, facilities of current design on typical sites are selected for the studies. The tentative schedule for the reports is as follows:

$\begin{array}{ll}\text { GFY } 1977 & \text { Fuel Reprocessing Plant } \\ \text { GFY } 1978 & \begin{array}{l}\text { Sma11 Mixed Oxide Fabrication Plant } \\ \text { Pressurized Water Reactor }\end{array} \\ \text { GFY 1979 } & \begin{array}{l}\text { Boiling Water Reactor } \\ \text { Low Level Waste Burial Ground } \\ \text { Uranium Mill }\end{array} \\ \text { GFY 1980 } & \begin{array}{l}\text { Uranium Fabrication Plant } \\ \text { Uranium Hexafluoride Conversion Plant }\end{array}\end{array}$

The following report is the first of these and covers a fuel reprocessing plant. The information provided in this report, including any comments, 
will be included in the record for consideration by the Commission in establishing criteria and new standards for decommissioning. Persons wishing to comment on this report should mail their comments to:

Chief

Fuel Process Systems Standards Branch Division of Engineering Standards Office of Standards Development Washington, DC 20555 


\section{ABSTRACT}

Safety and cost information were developed for the conceptual decommissioning of a fuel reprocessing plant (FRP) with characteristics similar to the Barnwell Nuclear Fuel Plant. The main process building, spent fuel receiving and storage station, liquid radioactive waste storage tank system, and a conceptual high-level waste solidfication facility were postulated to be decommissioned in this study. The plant was conceptually decommissioned to three decommissioning states or modes; layaway, protective storage, and dismantlement. These three modes range from minimal decommissioning requiring significant continued maintenance and surveiliance to complete removal of radioactivity with subsequent release of the site for unrestricted use. The decommissioning methods assumed for use in each decommissioning mode where based on state of the art technology.

Assuming favorable work performance, the elapsed time required to perform the decommissioning work in each mode following plant shutdown was estimated to be 2.4 years for layaway, 2.7 years for protective storage, and 5.2 years for dismantlement. These times include the solidification of the inventory of liquid high- and intermediate-level wastes existing at the time of shutdown which adds 1.3 years to each of the decommissioning periods. In addition to these times, approximately 2 years of planning and preparation are required before plant shutdown.

Costs, in constant 1975 dollars, for decommissioning were estimated to be $\$ 18$ million for layaway, $\$ 19$ million for protective storage and $\$ 58$ million for dismantlement. Maintenance and surveillance costs were estimated to be $\$ 680,000$ per year after layaway and $\$ 140,000$ per year after protective storage. The combination mode of protective storage followed by dismantlement deferred for 10,30 and 100 years was estimated to cost $\$ 64$ million, $\$ 67$ million and $\$ 77$ million, repectively, in nondiscounted total 1975 dollars. Present values of these costs give reduced costs as dismantlement is deferred.

Safety analyses indicate that radiological and nonradiological safety impacts from decommissioning activities should be smal1. The 50-year radiation 
dose commitment to the members of the public from airborne releases from normal decommissioning activities were estimated to be less than 11 man-rem. Radiation doses to the public from accidents were also found to be low for al1 phases of decommissioning. Occupational radiation doses from normal initial decommissioning operations were estimated to be 69,81 and 512 manrem for layaway, protective storage, and immediate dismantlement, respectively. Deferred dismantlement was found to reduce the public and occupational radiation doses. The number of fatalities and serious lost-time injuries not related to radiation were found to be small for the three decommissioning modes considered.

Examination of estimated total potential radiation exposures and present value of costs showed some incentive for doing a relatively small amount of decommissioning initially, and deferring dismantlement for up to about 30 years. This incentive might be offset by societal considerations such as the public perceiving the risk as being high and concern over the need for care of the facility/site for long time periods. Differences in manpower, resource commitment, aesthetic effects, ecological and environmental concerns among the three decommissioning approaches were found to be quite small.

Methods for assuring that the licensee has adequate funds for decommissioning were considered. Methods investigated (a11 based on expected decommissioning costs) range from a single payment when an operation begins, to accumlative payments during the normal plant operating period, to a single payment when decommissioning begins. Tentative conclusions favor the first two options for assuring availability of funds. 


\section{CONTENTS}

1.0 INTRODUCTION . . . . . . . . . . . . . . . . . .

REFERENCE • • • . . . . . . . . . . . . . . . 1-3

2.0 SUMMARY. . . . . . . . . . . . . . . . . . . . . . . . . $2-1$

2.1 STATUS OF REgULATORY GUIDANCE. . . . . . . . . . .

2.2 IMPORTANT FACILITY CHARACTERISTICS . . . . . . . . . 2-2

2.3 ESTIMATED RADIONUCLIDE INVENTORIES . . . . . . . . . 2-4

2.4 DISPOSITION CRITERIA. . . . . . . . . . . . . . 2-5

2.5 DECOMMISSIONING METHODS. • • • • • • • • • • •

2.5.1 Dismantlement Procedures . . . . . . . . . 2-7

2.5.2 Protective Storage Procedures . . . . . . . 2-9

2.5.3 Layaway Procedures . . . . . . . . . . . . 2-10

2.6 SAFETY . . . . . . . . . . . . . . . . . . 2-12

2.7 COSTS. . . . . . . . . . . . . . . . . . $2-13$

2.8 WASTES . . . . . . . . . . . . . . . . . . 2-15

2.9 APPROACHES TO FINANCING DECOMMISSIONING . . . . . . . 2-15

2.10 OVERALL COMPARISON OF DECOMMISSIONING ALTERNATIVES. . . . 2-16 REFERENCES . . . . . . . . . . . . . . . . . 2-17

3.0 DECOMMISSIONING ALTERNATIVES AND STUDY APPROACH . . . . . . . .

3.1 DECOMMISSIONING ALTERNATIVES . . . . . . . . . . . 3-1

3.1.1 Definition of and Rationale for Layaway . . . . . 3-3

3.1.2 Definition of and Rationale for Protective Storage . 3-4

3.1.3 Definition of and Rationale for Entombment . . . . 3-6

3.1.4 Definition of and Rationale for Dismantlement . . . 3-7

3.1.5 Viable Combinations of Decommissioning Modes . . . 3-8 
3.2 TECHNICAL APPROACH. . . . . . . . . . . . . . 3-11

3.3 KEY STUDY BASES . . . . . . . . . . . . . . . . . 3-13

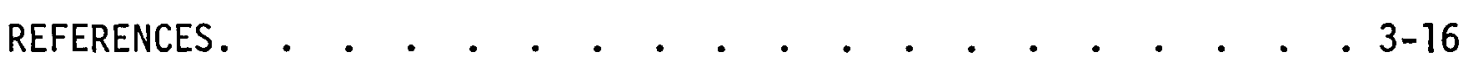

4.0 REGULATORY AND SAFEGUARDS CONSIDERATIONS. . . . . . . . . . 4- 4

4.1 EXISTING REGULATIONS, STANDARDS, AND GUIDES . . . . . . 4-1

4.1.1 Regulations Pertaining to the Planning and Preparation Phase. . . . . . . . . 4-2

4.1.2 Regulations Pertaining to the Decommissioning Phase . 4-6

4.2 SAFEGUARDS CONSIDERATIONS . . . . . . . . . . . . . 4-15 REFERENCES. • • . • . . . . . . . . . . . . . . 4-21

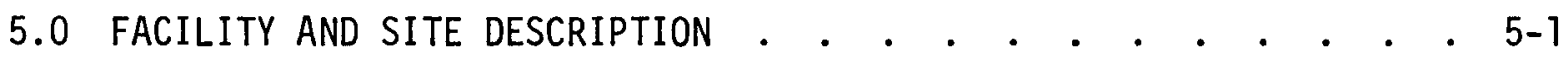

5.1 SITE DESCRIPTION . . . . . . . . . . . . . . . . 5-1

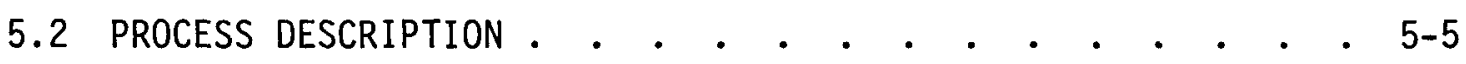

5.3 PLANT DESCRIPTION. • • • . . . . . . . . . . .

5.3.1 General Plant Design Bases . . . . . . . 5-11

5.3.2 Fuel Receiving and Storage Station. . . . . . 5-12

5.3.3 Main Process Building . . . . . . . . . 5-14

5.3.4 Liquid Waste Storage Areas . . . . . . . 5-18

5.3.5 Waste Solidification Plant . . . . . . . 5-19

5.3.6 Auxiliary Process Systems and Service Areas. . . . 5-22

5.4 RESIDUAL RADIOACTIVITY ESTIMATES. • . . . . . . . 5-24

5.5 CHEMICAL INVENTORIES. . . . . . . . . . . . . 5-27

REFERENCES. • • • • • • • • • • • • • • • • • • $5-28$

6.0 DISPOSITION CRITERIA . . . . . . . . . . . . . . . . 6-1

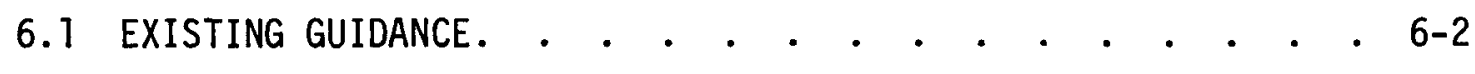

6.2 USE CATEGORIES. . . . . . . . . . . . . . . $6-3$ 
6.2.1 Use Category Selection Considerations. . . . . . 6-4

6.2 .2 Restricted Use . . . . . . . . . . . 6-5

6.2.3 Conditional Use. . . . . . . . . . . . 6-5

6.2.4 Unrestricted Use. . . . . . . . . . . . . 6-6

6.3 TECHNICAL APPROACH . . . . . . . . . . . . . . . $6-7$

6.3 .1 Logic . . . . . . . . . . . . . . . 6-7

6.3.2 Disposition Criteria Calculation . . . . . . 6-9

6.4 DISPOSITION CRITERIA. . . . . . . . . . . . . 6- . . . . .

6.4 .1 Site. . . . . . . . . . . . . . . . 6-11

6.4.2 Facility . . . . . . . . . . . . . 6-15

6.4.3 Disposition Criteria for Equipment and Material . 6-16

6.5 SUMMARY OF EXISTING GUIDANCE AND EXAMPLE

DISPOSITION CRITERIA.

6.6 MEASUREMENT CAPABILITY .

REFERENCES.

7.0 DECOMMISSIONING METHODS AND COST

7.1 PLANNING AND PREPARATION . . . . . . . . . . . . 7-3

7.1.1 Master Decommissioning Plan . . . . . . . 7-4

7.1 .2 Safety Analysis . . . . . . . . . . . 7-5

7.1.3 Quality Assurance Program. . . . . . . . 7-5

7.1.4 Safeguards and Security Plan. . . . . . . 7-6

7.1.5 Environmental Reports . . . . . . . . . 7-7

7.1 .6 Technical Specifications . • . . . . . . . 7-7

7.1 .7 NRC Review. . . . . . . . . . . . . 7-7

7.1 .8 Final Preparation . . . . . . . . . . 7-8

7.2 DECONTAMINATION METHODS. . . . . . . . . . . . . . . . 
7.2.1 Chemical Decontamination . . . . . . . . 7-9

7.2.2 Mechanical Decontamination . . . . . . . 7-16

7.3 DISMANTLEMENT MODE . . . . . . . . . . . . . . . 7-17

7.3.1 Overview of Dismantlement Activities . . . . . 7-17

7.3.2 Dismantlement of Main Process Building . . . . 7-23

7.3.3 Dismantlement of the Liquid Waste Tank Farm. • . 7-34

7.3.4 Dismantlement of the Waste Solidification Plant . . 7-39

7.3.5 Dismantlement of the Fuel Receiving and Storage Station. . . . . . . . . . . . . . 7-42

7.3.6 Dismantlement of the Auxiliary Facilities . . . 7-44

7.3.7 Structure Demolition and Site Restoration . . . 7-46

7.4 PROTECTIVE STORAGE MODE. • . . . . . . . . . . . 7-47

7.4.1 Overview of Protective Storage Activities . . . 7-47

7.4.2 Protective Storage Activities in the Main
Process Building. . . . . . . . . . . . . . . . .

7.4.3 Protective Storage Activities in the Liquid Waste Tank Farm. . . . . . . . . . . . 7-61

7.4.4 Protective Storage Activities in the Waste Solidification Plant . . . . . . . . 7-64

7.4.5 Protective Storage Activities in the Fuel Receiving and Storage Station . . . . . . 7-65

7.4.6 Protective Storage of Auxiliary Facilities . . . 7-66

7.4.7 Interim Care Period . . . . . . . . 7-67

7.4.8 Final Dismantlement Following Protective Storage... . . . . . . . . . . . . . . .69

7.5 LAYAWAY MODE. . . . . . . . . . . . . . . . . . . . . . . . . . . .

7.5.1 Overview of Layaway Activities . . . . . . . . . . . 
7.5.2 Layaway Activities in the Main Process Building. . . 7-73

7.5.3 Layaway Activities in the Liquid Waste Tank Farm . . . . . . . . . . . .7-80

7.5.4 Layaway Activities in the Waste Solidification Plant (WSP). . . . . . . . . . . .7-82

7.5.5 Layaway Activities in the Fuel Receiving and Storage Station . . . . . . . . . . .7-83

7.5.6 Layaway Activities in the Auxiliary Facilities . . .7-84

7.5.7 Interim Care Period . . . . . . . . . . . .7-85

7.5.8 Final Dismantlement Following Layaway . . . . . .7-86

7.6 DECOMMISSIONING WASTES AND WASTE DISPOSAL • . . . . . . . 7-89

7.7 DECOMMISSIONING MANPOWER REQUIREMENTS . • • • • • • . . . .96

7.7.1 Support Staff Requirements. . . . . . . . . . .96

7.7.2 Decommissioning Worker Requirements. . . . . . . .101

7.7.3 Labor Requirements During the Interim Care Period. . . . . . . . . . . . . . .7-110

7.7.4 Deferred Dismantlement Labor Requirements. • . . .7-112

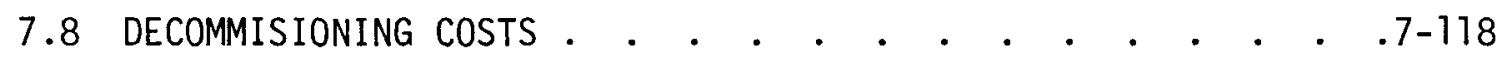

7.8.1 Direct Labor and Subcontractor Costs . . . . . .7-118

7.8.2 Equipment and Material Costs . . . . . . . . . . . . 25

7.8.3 Decommissioning Waste Packaging, Transportation and Disposal Costs . . . . . . . . . . . . . . . .

7.8.4 Costs of Utilities, Taxes and Other Owner Expenses. . . . . . . . . . . . . .7-131

7.8.5 Interim Care Costs . . . . . . . . . .7-134

7.8.6 Deferred Dismantlement Costs . . . . . . . . . . . • •

7.8.7 Cost Estimate Summaries. • . . . . . . . .7-140

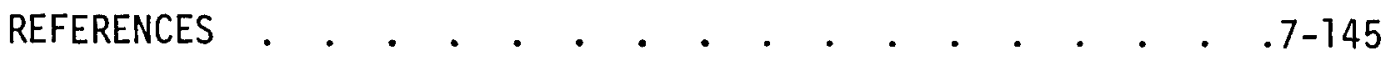


8.0 SAFETY OF DECOMMISSIONING A REFERENCE FUEL REPROCESSING PLANT. . 8-1

8.1 SCOPE OF THE SAFETY ANALYSIS . . . . . . . . . . . . 8-1

8.2 KEY ASSUMPTIONS/BASES USED IN THE SAFETY ANALYSIS . . . . 8-3

8.3 DISMANTLEMENT MODE SAFETY ASSESSMENT • . . . . . . . . 8-4

8.3.1 Dismantlement Operations Safety Assessment . . . 8-4

8.3.2 Dismantlment Transportation Safety. . . . . . 8-13

8.4 PROTECTIVE STORAGE MODE SAFETY ASSESSMENT. . . . . . . . 8-18

8.4.1 Protective Storage Operations Safety Assessment . . 8-18

8.4.2 Protective Storage Transportation Safety . . . 8-23

8.4.3 Interim Care Safety Impacts of Protective Storage. . 8-25

8.4.4 Safety Assessment of Deferred Dismantlement

Following Protective Storage. . . . . . . 8-29

8.5 LAYAWAY MODE SAFETY ASSESSMENT . . . . . . . . . . 8-34

8.5.1 Layaway Operations Safety Assessment . . . . . 8-34

8.5.2 Layaway Transporation Safety. . . . . . . . 8-39

8.5.3 Interim Care Safety Impacts of Layaway . . . . . 8-39

8.5.4 Safety Assessment of Deferred Dismantlement

Following Layaway . . . . . . . . . . . 8-40

9.0 COMPARISON OF ALTERNATIVE DECOMMISSIONING APPROACHES. . . . .

9.1 PARAMETERS FOR USE IN COMPARISON OF ALTERNATIVES . • .

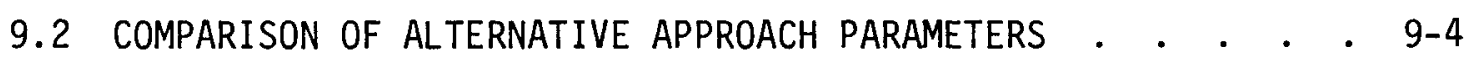

9.3 CONCLUSIONS. • . . . . . . . . . . . . . . . . 9-4

10.0 ALTERNATIVE APPROACHES TO FINANCING DECOMMISSIONING . . . . 10 10

10.1 OPTION I: PAYMENT OF COSTS WHEN INCURRED. . . . . . . 10-2

10.2 OPTION II: CREATION OF AN ANNUAL PAYMENT SINKING FUND • 10-3

10.3 OPTION III: PREPAYMENT OF COSTS. . . . . . . . . . . . 10-6

10.4 COMPARISON OF TOTAL COSTS . . . . . . . . . . . . $10-8$ 
10.5 SUMMARY AND CONCLUSIONS. . . . . . . . . . . . . . . . . . . .

11.0 DESIGN CONSIDERATIONS TO ENHANCE DECOMMISSIONING. . . . . . 11-1

12.0 GLOSSARY . . . . . . . . . . . . . . . . . . . 12-1

12.1 GLOSSARY-ABBREVIATIONS. . . . . . . . . . . . . 12-1

12.2 GLOSSARY-DEFINITIONS . . . . . . . . . . . . . 12-5

REFERENCES . . . . . . . . . . . . . . . . . . 12-24 


\section{FIGURES}

Figure

2.5-1 Sequence of Major Activities for Decommissioning the Reference Fuel Reprocessing Plant . . . . . . . . 2-8

3.1-1 Generalized Decommissioning Pathways and Alternatives for Many Fuel Cycle Facilities. . . . . . . . . . . 3-9

3.2-1 Approach for Decommissioning Study . . . . . . . . . 3-11

5.2-1 Simplified Process Flow Diagram for Reference Fuel Reprocessing Plant . . . . . . . . . . . . 5-7

5.3-1 Photograph of Barnwell Nuclear Fuel Plant. . . . . . . 5-10

5.3-2 Main Process and Fuel Receiving and Storage Station Buildings, Grade Elevations . . . . . . . . . 5-13

5.3-3 Main Process and Fuel Receiving and Storage Station Building, Upper Elevations. . . . . . . . . . . 5-15

5.3-4 HLLW Storage Tank. . . . . . . . . . . . . . . 5-19

5.3-5 Conceptual Waste Solidification Plant . . . . . . . . 5-21

5.3-6 Ventilation System Schematic for Process Areas of Reference Fuel Reprocessing Plant . . . . . . . . 5-23

6.3-1 Logic Diagram for the Development and Application of Disposition Criteria for Decommissioned Nuclear

Facilities and Sites. . . . . . . . . . . 6-8

6.3-2 Resuspension Factor as a Function of Time. . . . . . . 6-10

7.1-1 Approximate Schedule of Events for FRP Decommissioning Planning and Preparation Phase . . . . . . . . 7-4

7.3-1 Sequence of Major Activities for Dismantlement of the Reference Fuel Reprocessing Plant . . . . . . . 7-19

7.4-1 Sequence of Activities for Placing the Reference Fuel Reprocessing Plant in Protective Storage . . . . . 7-49

7.4-2 Temporary Pipeline for Pumping Residual Liquid From High Level Waste Tanks

7.4-3 Sequence of Events for Deferred Dismantlement of the Reference Fuel Reprocessing Plant Following Protective Storage . 
7.5-1 Sequence of Events for Placing the Reference

Fuel Reprocessing Plant in Layaway. . . . . . . 7-74

7.5-2 Sequence of Events for Deferred Dismantlement of the Reference Fuel Reprocessing Plant Following Layaway . . . . 7-88

7.7-1 Functional Organization Chart for Decommissioning the Reference Fuel Reprocessing Plant . . . . . . . . 7-97

7.7-2 Staff Organization for Dismantlement of the Reference Fuel Reprocessing Plant . . . . . . . 7-98

7.7-3 Staff Organization for Layaway and Protective Storage of the Reference Fuel Reprocessing Plant . . . .7-101

7.7-4 Summary of Estimated Decommissioning Worker Manpower Versus Time for Dismantlement of the Reference Fuel Reprocessing Plant . . . . . . . .7-108

7.7-5 Summary of Estimated Decommissioning Worker Manpower Versus Time for Placing the Reference Fuel Reprocessing Plant . .7-109

7.7-6 Summary of Estimated Decommissioning Worker Manpower Versus Time for Placing the Reference Fuel Reprocessing Plant in Layaway. . . . . . . . . . . . . . . . .7-109

7.7-7 Staff Organization and Estimated Manpower for Interim Care Following Layaway of the Reference Fuel Reprocessing Plant. . . . . . . . . . . . .7-111

7.7-8 Staff Organization and Estimated Manpower for Interim Care Following Protective Storage of the Reference Reprocessing Plant . . . . .7-113

7.7-9 Estimated Decommissioning Worker Manpower Versus Time for Deferred Dismantlement Following Protective Storage of the Reference Fuel Reprocessing Plant . . . .7-116

7.7-10 Estimated Decommissioning Worker Manpower Versus Time for Deferred Dismantlement Fol lowing Layaway of the Reference Fuel Reprocessing Plant . . . . . .7-116

9.2-1 Accumulated Decommissioning Costs in Constant 1975 Dollars . 9-6

9.2-2 Accumulated Present Value of Decommissioning Costs, Adjusted for Inflation. . . . . . . . . . . 9-6 
TABLES

VOLUME 1

TABLES

2.2-1 Reference Fuel Reprocessing Plant Characteristics and Their Effects on Decommissioning. . . . . . . . . . 2-3

2.3-1 Summary of Estimated Residual Radioactivity/Radiation in the Reference Fuel Reprocessing Plant . . . . . 2-4

2.4-1 Examples of Residual Contamination Levels for Reference Radionuclide Mixtures in the Reference Fuel Reprocessing Plant and its Site for Unrestricted Use . . . . . . 2-5

2.6-1 Summary of Safety Analysis - Decommissioning of Reference Fuel Reprocessing Plant. . $2-13$

2.7-1 Summary of Estimated Costs for Decommissioning the Reference Fuel Reprocessing Plant . . . . . . 2-14

2.7-2 Decommissioning Cost Distribution . . . . . . . . 2-14

2.8-1 Radioactive Wastes From Decommissioning . . . . . . 2-15

3.1-1 Decommissioning Mode Characteristics . . . . . . . 3-2

5.1-1 Estimated Maximum Amounts of Radioactive Materials Deposited on the FRP Site Over a 30 Year Operating Lifetime . . . . 5-4

5.2-1 Overall Processing Characteristics of the Reference Plant . 5-6

5.3-1 Primary Function of Areas in Fuel Receiving and Storage Station. . . . . . . . . . . . 5-14

5.3-2 Primary Functions of Main Process Cells . . . . . . 5-16

5.3-3 Primary Functions of Major Waste Solidification

Plant Process Cells... . . . . . . . . 5-20

5.4-1 Estimated Radioactivity Levels in the Reference Reprocessing Plant at Shutdown and After Chemical Decontamination . . . 5-25

6.4-1 Residual Contamination Levels at a Generic Site Corresponding to Candidate Dose Criteria at Selected

Times after Shutdown . . . . . . . . . . . 6-12

6.4-2 Residual Contamination Levels at a Generic Site Corresponding to Candidate Dose Criteria with the Thyroid G1 and as the Organ of Reference.. . . . 6-13 
TABLES

6.4-3 Residual Contamination Levels at a Generic Site Corresponding to Candidate Dose Criteria at Selected

Time after Shutdown. Conditional use - no farm products. . 6-14

6.4-4 Residual Contamination Levels at a Generic Site Corresponding to Candidate Dose Criteria with the Thyroid Gland as the Organ of Reference. Conditional use - no farm products... . . . . . . . . . . 6-15

6.4-5 Residual Contamination Levels Within the Reference Facility Corresponding to Candidate Dose Criteria at Selected Times after Shutdown.

6.4-6 Residual Contamination Levels Within the Reference Facility Corresponding to Candidate Dose Criteria with the Lung as the Organ of Reference.

6.5-1 Regulatory Guide 1.86 Acceptable Surface Contamination Levels . . . . . . . . . . . . . . 6-18

6.5-2 ANSI N328 Surface Contaminatio Limits (Proposed) . . . . 6-18

6.5-3 Al lowable Residual Contamination Levels Derived for the Reference Fuel Reprocessing Plant Located at a Generic Site

6.6-1 Detection Capabilities for Environmental Sample Analysis. 6-21

6.6-2 Detection Capabilities for Environmental Sample Analysis. . 6-23

6.6-3 Comparison of Measurement Methods for Release Surveys. . . 6-24

7.3-1 Outline of Dismantlement Activities. . . . . . . . . 7-20

7.4-1 Outline of Protective Storage Activities . . . . . . . 7-51

7.4-2 Previously Completed Activities and Additional

Activities for Deferred Dismantlement Following

Protective Storage

7.5-1 Outline of Layaway Activities. . . . . . . . . . 7-75

7.5-2 Previously Completed Activities and Additional

Activities for Deferred Dismantlement Following Layaway.

7.6-1 Assumed Origins of TRU and non-TRU Decommissioning Wastes 
TABLES

7.6-2 Packaging and Shipping Information for TRU Wastes

Generated from Dismantlement of the Reference Fuel

Reprocessing Plant . . . . . . . . . . . 7-94

7.6-3 Packaging and Shipping Information for Non-TRU

Wastes Generated from Dismantlement of the Reference

Fuel Reprocessing Plant. . . . . . . . . . . 7-95

7.7-1 Summary of Estimated Support Staff Labor Requirements

for Immediate Dismantlement of the Reference Fuel

Reprocessing Plant. . . . . . . . . . . .7-100

7.7-2 Summary of Estimated Support Staff Labor

Requirements for Protective Storage of the

Reference Fuel Reprocessing Plant . . . . . . .7-102

7.7-3 Summary of Estimated Support Staff Labor

Requirements for Layaway of the Reference Fuel

Reprocessing Plant . . . . . . . . . . .7-103

7.7-4 Summary of Estimated Decommissioning Worker

Manpower Requirements for Dismantlement of the

Reference Fuel Reprocessing Plant . . . . . . .7-107

7.7-5 Summary of Estimated Decommissioning Worker Manpower

Requirements for Placing the Referenced Fuel

Reprocessing Plant in Protective Storage . . . . . . 7-107

7.7-6 Summary of Estimated Decommissioning Worker Manpower

Requirements for Placing the Reference Fuel Repro-

cessing Plant in Layaway . . . . . . . . . .7-108

7.7-7 Summary of Estimated Support Staff Labor for Deferred

Dismantlement Following Protective Storage and

Layaway of the Reference Fuel Reprocessing Plant . . . .7-115

7.8-1 Estimated Support Staff Labor Costs for Immediate

Dismantlement of the Reference Fuel Reprocessing Plant . .7-119

7.8-2 Estimated Support Staff Labor Costs for Placing the

Reference Fuel Reprocessing Plant in Protective

Storage... . . . . . . . . . . . .7-120

7.8-3 Estimated Support Staff Labor Costs for Placing

the Reference Fuel Reprocessing Plant . . . . . . .7-120

7.8-4 Estimated Decommissioning Worker Labor Costs for

Immediate Dismantlement of the Reference Fuel

Reprocessing Plant 
$\underline{\text { TABLES }}$

7.8-5 Estimated Decommissioning Worker Labor Costs for Placing the Reference Fuel Reprocessing Plant in Protective Storage . . . . . . . . . . . . .7-122

7.8-6 Estimated Decommissioning Worker Labor Costs for Placing the Reference Fuel Reprocessing Plant in Layaway . . . .7-123

7.8-7 Estimated Subcontractor Costs for Immediate Dismantlement of the Reference Fuel Reprocessing Plant . . .7-124

7.8-8 Estimated Subcontractor Costs for Placing the Reference Fuel Reprocessing Plant in Protective Storage.

7.8-9 Estimated Equipment Costs for Dismantlement of the Reference Fuel Reprocessing Plant . . . . . .7-126

7.8-10 Estimated Equipment Costs for Placing the Reference Fuel Reprocessing Plant in Protective Storage

7.8-11 Estimated Equipment Costs for Placing the Reference Fuel Reprocessing Plant in Layaway. . . . . .7-128

7.8-12 Basic Decommissioning Waste Management Cost Data . . . 7-129

7.8-13 Estimated Packaging, Shipping and Waste Disposal Charges for Transuranic Wastes from Dismantlement of the Reference Fuel Reprocessing Plant . . . . . .7-130

7.8-14 Estimated Packaging, Shipping and Waste Disposal Costs for Low Level, Nontransuranic Wastes from Dismantlement of the Reference Fuel Reprocessing Plant . .7-131

7.8-15 Estimated Packaging, Shipping and Waste Disposal Costs for Low Level, Nontransuranic Wastes from Dismantlement of the Reference Fuel Reprocessing Plant . .7-132

7.8-16 Estimated Costs of Utilities, Taxes and Other Owner Expenses During Dismantlement of the Reference Fuel Reprocessing Plant . . . . . . . . . . . .7-132

7.8-17 Estimated Costs of Utilities, Taxes and Other Owner Expenses During Protective Storage or Layaway of the Reference Fuel Reprocessing Plant . . . .7-133

7.8-18 Estimated Annual Costs of the Interim Care Activities After Protective Storage of the Reference Fuel Reprocessing Plant 
7.8-19 Estimated Annual Costs of Interim Care Activities

After Layaway of the Reference Fuel Reprocessing Plant . .7-136

7.8-20 Estimated Support Staff Labor Costs for Deferred

Dismantlement Following Protective Storage of

the Reference Fuel Reprocessing Plant . . . . . . .7-137

7.8-21 Estimated Subcontractor Costs for Deferred Dismantlement After Protective Storage of the Reference Fuel Reprocessing Plant . . . . . . . .7-138

7.8-22 Estimated Subcontractor costs for Deferred Dismantlement After Layaway of the Reference Fuel Reprocessing Plant. . . . . . . . . . . . .7-139

7.8-23 Estimated Cost of Utilities, Taxes and Other Owner Expenses During Deferred Dismantlement Following Layaway or Protective Storage of the Reference Fuel Reprocessing Plant . . . . . . . .7-140

7.8-24 Summary of Cost Estimates for Immediate Dismantlement of the Reference Fuel Reprocessing Plant.

7.8-25 Summary of Cost Estimates for Protective Storage, Interim Care and Deferred Dismantlement of the Reference Fuel Reprocessing Plant . . . . . .7-141

7.8-26 Summary of Cost Estimates for Layaway, Interim Care and Deferred Dismantlement of the Reference Fuel Reprocessing Plant. . . . . . . . . . . .7-142

8.3-1 Estimated Radiation Dose to the Public From Release of Radionuclides During Normal Dismantlement Decommissioning Operations.

8.3-2 Estimated Occupational Radiation Doses from Dismantlement.

8.3-3 Estimated Radiation Dose to the Public from Accidental Release of Radionuclides During Dismantlement Decomissioning Operations.

8.3-4 Estimated Worker Lost-Time Injuries and Fatalities from Dismantlement Operations . . . . . . . . . . . 8-13

8.3-5 Estimated Routine Radiation Dose from Rail Transport of Radioactive Wastes from Dismantlement . . . . . . 8-14 
8.3-6 Estimated Routine Radiation Dose from Truck Transport of Radioactive Wastes from Dismantlement . . . . . . 8-14

8.3-7 Estimated Frequencies and Radioactivity Releases for Selected Accidents Involving Rail and Truck Transport of Radioactive Wastes from Dismantlement . . . . . 8-16

8.3-8 Estimated Injuries and Fatalities from Dismantlement Transportation Accidents . . . . . . . . . . . . 8-17

8.4-1 Estimated Radiation Dose to the Public from Release of Radionuclides During Normal Protective Storage Decommissioning Operations.

8.4-2 Estimated Occupational Radiation Dose from Protective Storage for all Decommissioning Staff. . . . . . 8-20

8.4-3 Estimated Radiation Dose to the Public from Accidental Release of Radionuclides During Protective Storage Decommissioning Operations.

8.4-4 Estimated Worker Lost-Time Injuries and Fatalities from Protective Storage Operations . . . . . . . . 8-23

8.4-5 Estimated Routine Radiation Dose from Rail Transport of Radioactive Wastes from FRP Protective Storage . . . . 8-24

8.4-6 Estimated Routine Radiation Dose from Truck Transport of Radioactive Wastes from FRP Protective Storage . . . . 8-24

8.4-7 Estimated Frequencies, Releases and Radiation Doses for Selected Accidents Involving Rail and Truck Transport of Radioactive Wastes from FRP Protective Storage . . . . 8-26

8.4-8 Estimated Injuries and Fatalities from Protective Storage Transportation Accident . . . . . . . . . 8-27

8.4-9 Estimated Occupational Radiation Doses from Interim Care Following Protective Storage . . . . . . . . 8-28

8.4-10 Nonradiological Occupational Accidents During Protective Storage Interim Care. . . . . . . . . . 8-29

8.4-11 Correction Factors for Inhalation Radiation Dose to Account for Radioactive Decay. . . . . . . . . . . 8-30

8.4-12 Estimated 0ccupational Radiation Exposures for Deferred Dismantlement Following Protective Storage . . 8-31 
$\underline{\text { TABLES }}$

8.4-13 Estimated Worker Lost-Time Injuries and Fatalities

for Deferred Dismantlement Following Protective

Storage... . . . . . . . . . . . 8-32

8.4-14 Correction Factors for External Radiation Doses from

Normal Transportation Operations to Account for

Radioactive Decay.

8.4-15 Estimated Truck and Rail Total Shipment Kilometers

Immediate and Deferrèd Dismantlement After Protective

Storage .

8.5-1 Estimated Radiation Dose to the Public from Release of

Radionuclides During Normal Layaway Decommissioning

Operations.

8.5-2 Estimated Occupational Radiation Dose from Layaway for al1 Decommissioning Staff. . . . . . . . . . . 8-37

8.5-3 Estimated Radiation Dose to the Public from Accidental

Release of Radionuclides During Layaway Decommissioning

Operations

Estimated Worker Lost-Time Injuries and Fatalities from

Layaway Operations . . . . . . . . . . . . . 8-38

8.5-5 Estimated Occupational Radiation Doses for Interim

Care Following Layaway . . . . . . . . . . . . 8-40

8.5-6 Nonradiological Occupational Accidents During Layaway

Interim Care . . . . . . . . . . . . . . . . 8-41

9.2-1 Values of Parameters for Alternative Decommissioning

Approach Comparisons. . . . . . . . . . . . . . 9-5

10.4-1 Present Value Cost Comparison of Alternative

Financing Options. . . . . . . . . . . . . . . . 10-9

10.4-2 Effect of Insurance Fees on Present Value of Cost
Comparisons. . . . . . . . . . . . . . . . . . . 10

Relative Desirability of Decommissioning Financing
Operations. . . . . . . . . . . . . . . . . . . . . $12-12$ 


\subsection{INTRODUCTION}

This report presents the results of a study sponsored by the U.S. Nuclear Regulatory Commission (NRC) to conceptually decommission a facility for chemical reprocessing of spent nuclear fuels from Light Water Reactors (LWRs). It is the first study completed as a part of the overall NRC program covering the decommissioning of LWRs and LWR fuel cycle facilities.

The primary purpose of this study is to provide information on safety and costs of decommissioning a contemporary fuel reprocessing plant (FRP), and it is intended to contribute background information and bases for future regulations regarding decommissioning of an FRP. Decommissioning techniques were reviewed and conceptually applied to a facility. Potential new guidelines and criteria were developed and utilized where appropriate.

Decommissioning a nuclear facility can be defined as the measures taken at the end of the facility's operating lifetime to assure the continued protection of the public from the residual radioactivity and other potential hazards in the retired facility. A wide variety of final stages or "disposition modes" is possible for a retired nuclear facility. Four basic decommissioning modes that have been identified are: layaway, protective storage, entombment and dismantlement. (a) These modes range from minimal removal and fixation of residual radioactivity requiring continuing active surveillance, to removal of much of the facility and all hazardous materials and restoration of the site to approximately its pre-facility condition. Eventual dismantlement supports the NRC's general objective of minimizing the number of sites with long term dedication to radioactivity containment.

Three of the four basic decommissioning modes were selected for evaluation in this study: dismantlement, protective storage and layaway. The entombment mode was not included because it limits future options for reuse or further decommissioning of the facility.

An existing facility, the Allied General Nuclear Services (AGNS) Barnwell Nuclear Fuel Plant (BNFP) was selected as the reference facility for this

(a) The latter three modes are defined in Reference (1). 
conceptual analysis. Although the Barnwell facility is not yet operating, its design and construction are nearly complete. It is believed to be the most representative of existing contemporary commercial fuel reprocessing plants in the U.S. The main chemical process building, spent fuel receiving and storage station, liquid radioactive waste storage tank farm, and a conceptual high-level liquid waste solidification facility were postulated to be decommissioned in this study. The $\mathrm{UF}_{6}$ and future $\mathrm{PuO}_{2}$ conversion facilities, onsite storage area for solid radioactive wastes, and water storage pond and other service facilities were considered outside the scope of this study, but will be considered in future studies planned for other fuel cycle facilities.

A work plan was developed for the conceptual decommissioning of the reference FRP for each of the decommissioning modes studied. These plans describe decommissioning methods, technology and scheduling, from the planning phase through disposal of material. From application of these plans, estimates were developed of manpower, major equipment and material needs, material disposal requirements, and their resultant costs. The primary guiding philosophy for these plans was:

- to maximize public and occupational safety during decommissioning in a cost-effective manner

- to use only current, proven decontamination and decommissioning techniques.

Variations are possible to the work plans and techniques described in this study to accomplish each of the three decommissioned states. However, the methods selected appear to be representative of activities expected for decommissioning a FRP, and are believed to reflect an appropriate balance of safety and cost.

The safety aspects of performing the decommissioning activities, as they affected both the general public and decommissioning workers were assessed. Safety and cost issues were also evaluated for the periods following the layaway and protective storage modes, wherein radioactive materials remaining at the site for extended periods of time will require continuing surveillance and maintenance. 
Safeguards and accountability for handling fissile materials, quality assurance needs, and methods for assuring decommissioning finances were examined. Relative environmental and social advantages and disadvantages are compared where possible, for each of the three decommissioning modes studied. Criteria were developed for acceptable contamination levels for various categories of facility and site reuse, based upon the potential for radiation exposure to the public.

Many aspects of decommissioning (e.g., plans, methods, safety and costs) may be sensitive to variations in facility location, specific facility shutdown conditions and residual contamination levels in the plant. The bases and assumptions used in this study must be carefully examined before the results can be applied to a different facility and site.

The results of the study are reported in two volumes: Volume I (Main Report) summarizes the key information developed; and Volume II (Appendices) contains the supporting data, methodology, and analyses. Volume I contains a summary and general material (i.e., decommissioning mode definitions, study approach, applicable regulations and safeguards considerations, plant and site description and disposition criteria). The decommissioning techniques, quality assurance needs, and associated costs are described for each mode. Safety analyses for all of the modes are then presented. An overall comparison of the study results is presented, followed by analysis of methods for assuring financial capability for decommissioning. A glossary of terms completes Volume I. Volume II contains appendices organized in sections corresponding to those in Volume $I$.

\section{REFERENCE}

1. U.S. Atomic Energy Commission Regulatory Guide 1.86, Termination of Operating Licenses for Nuclear Reactors, June 1974. 
•

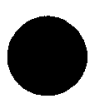




\subsection{SUMMARY}

This section summarizes the results of a study to investigate the conceptual decommissioning of a reference fuel reprocessing plant (FRP). The primary purpose of the study is to evaluate the safety, costs, and other related aspects of decommissioning a fuel reprocessing plant. The study is intended to provide background information for future regulations, designs, and operational characteristics of fuel reprocessing plants with regard to their decommissioning.

The Barnwell Nuclear Fuel Plant (BNFP) was selected as the reference fuel reprocessing plant and was characterized for decommissioning activities. For this study, the facility was placed on a hypothetical generic river-side site with characteristics typical of mid-western or mid-southeastern areas. Decommissioning plans, procedures, and schedules were developed for several decommissioning alternatives for all plant areas planned to contain radioactive materials (and the unseparable adjacent areas with no radioactivity), except for the $\mathrm{UF}_{6}$ conversion facility, ${ }^{(a)}$ a currently planned plant for conversion of plutonium nitrate to plutonium dioxide, ${ }^{(a)}$ and the area for interim storage of nonhighlevel solid wastes. (a) The portion of the facility where high- and intermediatelevel liquid wastes are solidified was conceptualized and included in this study. Costs and safety impacts were estimated for each of the selected decommissioning alternatives, and comparisons of overall costs and benefits were made. Methodology was developed to determine acceptable contamination levels and example numerical values were derived for selected facility and site uses.

Some of the key bases for the study are:

- The three decommissioning modes selected are: Layaway, Protective Storage, and Dismantlement. These modes form a spectrum of viable decommissioning options for a fuel reprocessing plant.

- Decommissioning plans are selected on the basis of providing good public and occupational safety in a cost-effective manner.

(a) Areas similar to these will be covered in future studies. 
- Decommissioning operations are evaluated assuming efficient performance of the work.

- Current decommissioning technology and techniques are used.

- Expected residual contamination levels within the facility/site are based on relatively good housekeeping practices during plant operation. This residual radioactive material at the time of plant shutdown is assumed to have accumulated at the rate of 1/30 per year for the assumed 30-year plant life.

- Decommissioning wastes that contain transuranic radionuclides greater than $10 \mathrm{nCi}$ per gram of waste or significant amounts of fission products are assumed to be sent to deep geologic disposal. Other wastes are sent to regulated shallow burial grounds.

- The reference reprocessing plant is the only nuclear facility on the site. The results obtained in this study are specific to these key bases and to the other bases and assumptions used in this study. Use of other conditions, bases, and assumptions (e.g., contamination levels) may change the results significantly.

\subsection{STATUS OF REGULATORY GUIDANCE}

Regulatory and Federal guidelines were reviewed relative to their general application to decommissioning and specifically to the decommissioning of a nuclear fuel reprocessing plant. The review shows that regulations do exist that can be applied to most activities associated with decommissioning, including safeguards considerations.

Areas are identified where more specific guidance is needed and where strict application of existing regulations to decommissioning may be inappropriate.

\subsection{IMPORTANT FACILITY CHARACTERISTICS}

Some of the more important design features of the BNFP that affect the major decommissioning considerations, and the general effects of these features 
decommissioning (i.e., favorable or unfavorable) are given in Table 2.2-1. The unfavorable features merit consideration for modifications during the design of a facility.

\section{TABLE 2.2-7. Reference Fuel Reprocessing Plant Characteristics and Their Effects on Decommissioning}

\author{
Characteristics \\ Mnst main nrocessing areas are con- \\ structed of thick, heavily rein- \\ forced concrete. \\ Main process functions are divided \\ into separate shielded rooms \\ (cells).
}

Process cells contain complex networks of piping.

Some process cells have installed maintenance equipment that permits remote decommissioning.

Most process cells require direct personnel access to work within the cells.

Most process cells have protective coatings or liners.

Process cells have built-in spray systems (mist and pressure sprays) for chemical decontamination of external surfaces.

Facility has highly efficient ventilation and filtration system.

Facility has major liquid waste storage and solidification system.
Effects on Decommissioning

\begin{tabular}{l} 
Favorable \\
\hline Separation allows isola- \\
tion of areas for decom- \\
missioning. \\
High corrosion resistance \\
of piping aids in chemical \\
decontamination. \\
Remote decommissioning re- \\
duces occupational expo- \\
sure and need for special \\
equipment/techniques.
\end{tabular}

Direct access increases occu-

Stainiess steel floors in most cells (and walls in a few cells) are easier to decontaminate than concrete; protective paints reduce contamination in concrete.

Spray system provides for in-place chemical decontamination.

System maintains low effluents during decommissioning operations.

Can process and solidify most liquid decommissioning wastes within the plant. pational exposure and need for special equipment/ techniques.

Concrete is difficult to decontaminate. Reinforced concrete is difficult to remove.

Many process functions are combined into each cell, causing interferences in decommissioning the various process functions.

Complex piping is difficult to decontaminate and remove.

Protective paints have high potential to lose integrity, thereby exposing difficultto-decontaminate concrete.

Sprays can not reach all contaminated areas.

Time is required to decommission the process inventory of production wastes at plant shutdown. Liquid waste storage is very complex and costly to decommission. 


\subsection{ESTIMATED RADIONUCLIDE INVENTORIES}

Estimates were made of residual radioactivity within the plant after final operational flushing and after chemical decontamination. Numerous activities could occur during the operational phase of the facility that could significantly affect radionuclide inventories. The estimates in this study, shown in Table 2.3-1, are based on engineering judgment considering the design characteristics of the BNFP and assuming good housekeeping practices during plant operation.

TABLE 2.3-1. Summary of Estimated Residual Radioactivity/Radiation in the Reference Fuel Reprocessing Plant

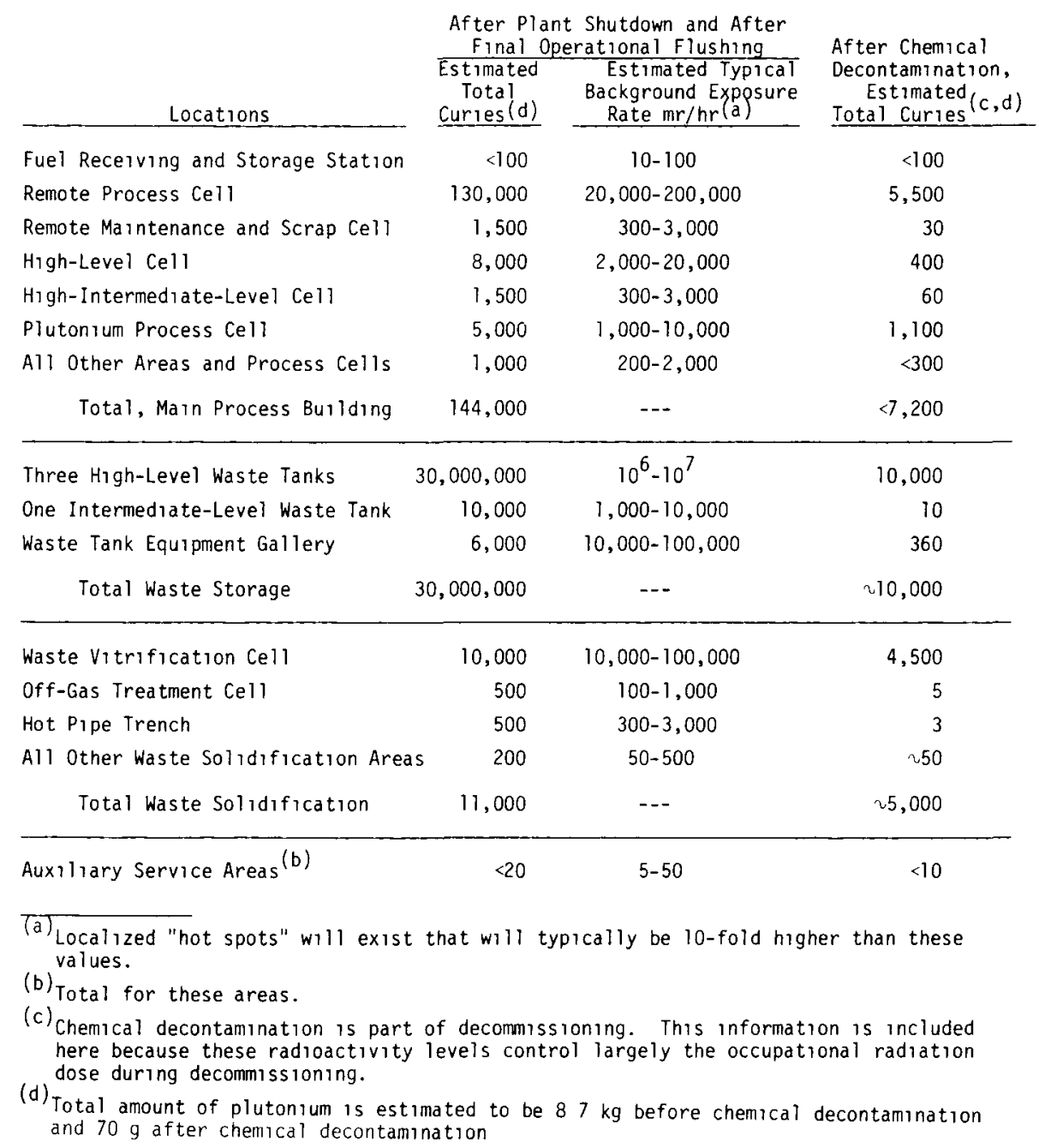




\subsection{DISPOSITION CRITERIA}

Methodology is presented for developing numerical values for allowable residual radioactive contamination levels of decommissioned facilities and sites. The methodology is based on annual dose criteria for potential radiation exposure to any member of the public for unrestricted use of the reference facility and/or site. Because the establishment of numerical dose criteria is currently under investigation, a range of 1 to $25 \mathrm{mrem} /$ year was selected for calculation of the maximum annual dose to any organ of a maximum exposed member of the public. The methodology permits calculation of allowable contamination levels which correspond to the maximum annual dose to the maximum exposed individual from all exposure pathways.

Using a unit annual dose criterion of $1 \mathrm{mrem} / y e a r$, residual contamination levels are calculated for the reference radionuclide mixture expected in the reference plant from the processed spent LWR fuel. Another set of residual levels was calculated for a reference radionuclide mixture expected in the site soil from facility effluent releases. Both sets of allowable residual contamination levels were calculated for several time spans between plant shutdown and decommissioning. The results are given in Table 2.4-1.

\section{TABLE 2.4-1. Examples of Residual Contamination Levels for Reference Radionuclide Mixtures in the Reference Fuel Reprocessing Plant and its Site for Unrestricted Use}

\begin{tabular}{|c|c|c|}
\hline Location & $\begin{array}{l}\text { Time } \\
\text { After Plant } \\
\text { Shutdown }(a) \\
\text { Years } \\
\end{array}$ & $\begin{array}{c}\text { Allowable Residual } \\
\text { Contamination Level, } \mathrm{HC}_{1} / \mathrm{m}^{2} \text {, } \\
\text { Based on Maxpmum Annual } \\
\text { Dose }(\mathrm{b}) \text { of } \\
\text { I mrem } / \mathrm{yr}(\mathrm{c})\end{array}$ \\
\hline \multirow[t]{4}{*}{ Facility } & 0 & $14 E-2$ \\
\hline & 10 & I $5 \mathrm{E}-2$ \\
\hline & 30 & $17 \mathrm{E}-2$ \\
\hline & 100 & $2 O E-2$ \\
\hline \multirow[t]{4}{*}{ Site } & 0 & $82 E-3$ \\
\hline & 10 & $56 E-3$ \\
\hline & 30 & $43 E-3$ \\
\hline & 100 & $32 E-3$ \\
\hline \multicolumn{3}{|c|}{$\begin{array}{l}\text { (a) Time between shutdown of facility and decommissioning } \\
\text { (b) Maximum annual dose to any organ from all exposure path- } \\
\text { ways to any member of the public following unconditional } \\
\text { release of the facility or site } \\
\text { (c) For any other maximum annual dose, multiply these values } \\
\text { by the new maximum annual dose in mrem/yr }\end{array}$} \\
\hline
\end{tabular}


For the reference fuel reprocessing plant site, ${ }^{129}$ I was found to be th principal contributor to the annual dose. For the facility, no particular radionuclide appears to be dominant. The allowable residual contamination levels at the site decrease with time because the principal dose contributor, ${ }^{129}{ }^{1}$, does not decay within the time period of concern, and its contribution to the measurable, residual contamination level is negligible. For the mixture of radionuclides calculated to remain at the plant site, the contamination levels shown in Table 2.4-1 will potentially result in a maximum annual dose of 1 mrem.

As dose 1 imits are promulgated by authoritative agencies, corresponding allowable residual contamination levels can be developed. The values derived in this study are dependent upon the specific conditions assumed.

\subsection{DECOMMISSIONING METHODS}

A plan and set of procedures were developed for each of the three modes studied for decommissioning the reference fuel reprocessing plant.

The first decommissioning phase for each mode is termed "Planning and Preparation." This phase takes place during the last two years of normal plant operation. During this phase, the decommissioning staff is assembled, a decommissioning plan and procedures are prepared; safety and safeguards analysis reports and an environmental impact evaluation are prepared; an application for a modified license is prepared and approval is received; a quality assurance program is established; health and safety requirements are developed; bulk quantities of unneeded process chemicals, radioactive materials and nonessential equipment are removed, and modification of effluent control systems is initiated.

For decommissioning purposes, the facility is generally divided into five types of areas:

- main process building

- fuel receiving and storage area

- liquid waste storage area

- high- and intermediate-level waste solidification area

- auxiliary systems 
Decommissioning is assumed to be done on the basis of 5 days per week and one shift. A few activities are performed on a 2- or 3-shift basis. Decommissioning of the main building is started first. Decommissioning of the liquid waste storage area, waste solidification area, and the fuel receiving and storage area starts about 1.5 years after that of the main process building begins. Most of the auxiliary systems are done as the last steps. Inventories of 1 iquid process wastes being stored at the time of plant shutdown require solidification before tanks containing these wastes can be decommissioned, thus delaying the completion of all decommissioning modes. A graphic summary of decommissioning events is given in Figure 2.5-1. Summary discussions of these events are presented in the next three subsections.

Entombment was not considered to be a viable decommissioning mode for the reference fuel reprocessing plant, and thus was not studied. Entombment is intended for use where the residual radioactivity decays to innocuous levels within reasonable time periods (on the order of 100 years). The type of radioactivity in a fuel reprocessing plant precludes this from occurring. Furthermore, entombment severely complicates final decommissioning and appears to offer no advantages over protective storage.

\subsubsection{Dismantlement Procedures}

After planning and preparation, dismantlement operations are divided into four additional major phases:

- chemical decontamination

- removal of contaminated equipment

- mechanical decontamination of structures

- demolition of structures and restoration of the site.

Some of these phases for different parts of the facility can proceed simultaneously.

Chemical decontamination involves remote flushing of internal surfaces of process piping and equipment, followed by remote spraying with a series of chemical solutions of the external surfaces of process equipment, piping and structure surfaces. 
DISMANT LEMENT

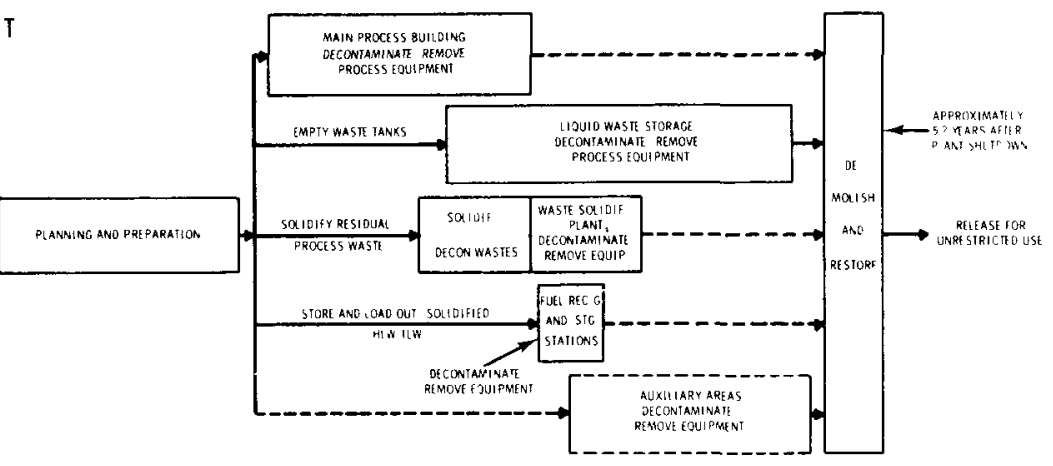

is
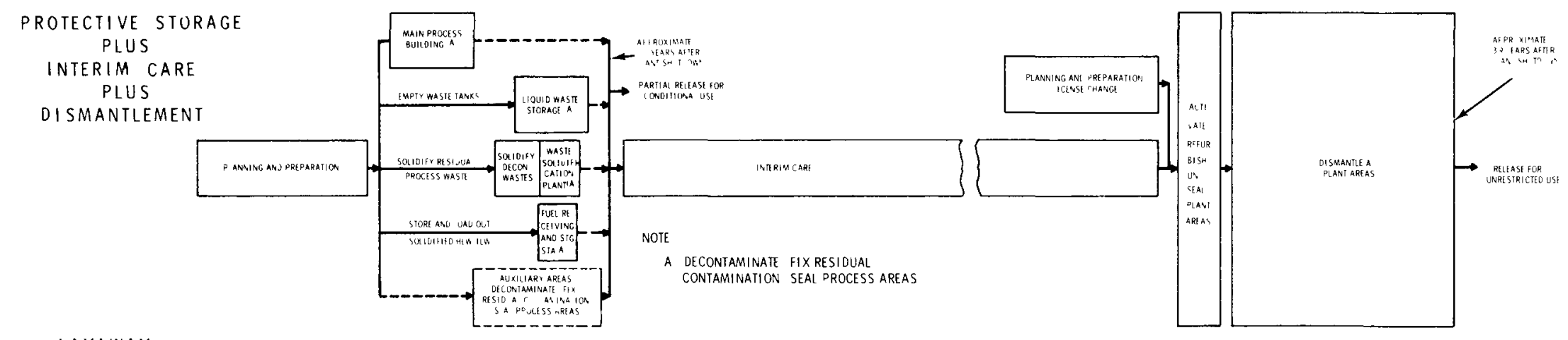

LAYAWAY
PLUS

INTERIM CARE

PLUS

DI SMANTLEMENT
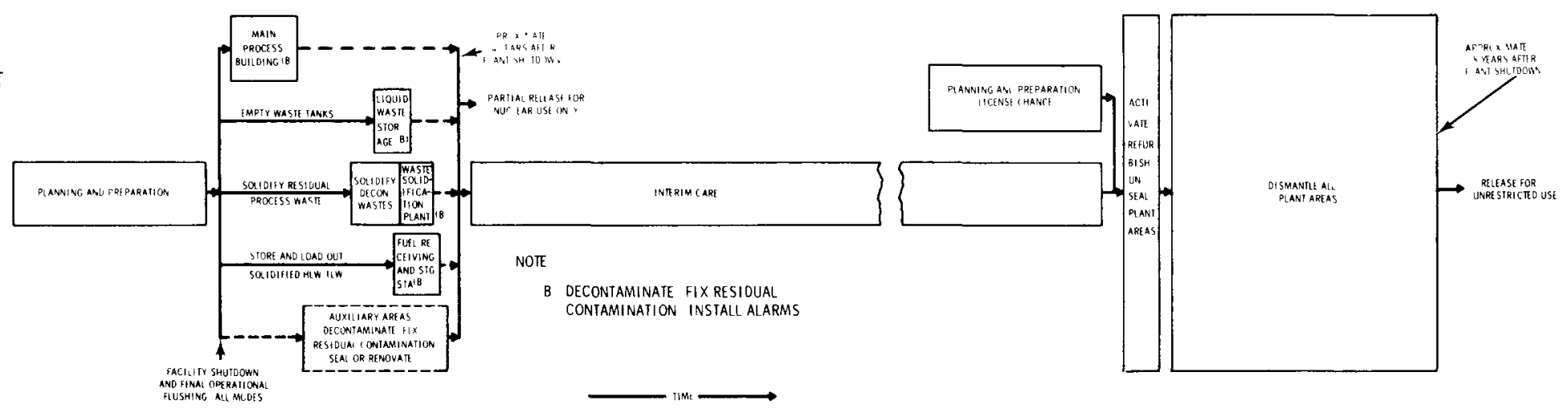

FIGURE 2.5-1. Sequence of Major Activities for Decommissioning the Reference Fuel Reprocessing Plant 
Removal of contaminated equipment involves disconnecting and cutting where necessary, packaging, loading and transportation of contaminated equipment to an offsite waste disposal facility. A plasma torch is used to cut metallic materials. Where radiation levels do not permit contact operations, a remote operational capability is added or a specially-constructed portable shielded working cage is used to accomplish equipment removal.

During mechanical decontamination, contaminated portions of the plant structures are removed, packaged, and transported to offsite disposal facilities. Contaminated layers of concrete are removed using techniques such as small explosive charges, drilling and rocksplitting or jackhammering.

In the demolition and restoration phase, a 11 above-grade portions of structures undergoing decommissioning are demolished using conventional methods such as explosives and impact balls. The site is then graded and planted with vegetation to near pre-facility conditions. The facility site is then released for unrestricted use.

\subsubsection{Protective Storage Procedures}

After planning and preparation, the protective storage activities are divided into seven additional phases:

- chemical decontamination

- mechanical decontamination and fixing of residual radioactivity

- equipment deactivation

- isolation of contaminated areas

- preparations for surveillance, maintenance, and interim care

- interim care (surveillance and maintenance)

- final dismantlement

The chemical decontamination activities for protective storage are essentially the same as for the dismantlement mode.

In the next phase, contaminated equipment is removed to portions of the facility (i.e., process cells) that are to be isolated by rigid barriers. other remaining low levels of contamination are fixed in place by covering with multiple layers of protective paints. 
Next, a11 equipment and systems not used are deactivated. Typical activities include closing valves, blanking flanges, and disconnecting utilities. Only "passive" safety systems such as radiation monitors, fire detection and fighting equipment remain operable after this phase.

Isolation of contaminated areas involves sealing all access points with nonoperable steel plate barriers that are welded or bolted.

Preparations for surveillance and maintenance activities include welding shut most exterior doors and installing electronic intrusion alarms and other safety instrumentation. A11 other safety equipment such as fire detection and fire fighting equipment and radiation monitoring equipment are inspected and repaired or upgraded as necessary. Remote readouts of monitoring systems are provided to assure continual surveillance of the facility. The immediate plant area is made inaccessible to the public. The bulk of the large site is released for public access and conditional (or restricted) use after licensing approval.

During the interim care phase, surveillance, maintenance, and security activities are conducted, using primarily electronic monitoring devices and periodic inspections. A scheduled program is established for radiation and environmental monitoring, repair of safety-related items, and periodic reporting of status and activities to regulatory agencies.

Final dismantlement begins with another planning and preparation phase, including application for and approval of facility license change. The facility equipment that is necessary for dismantlement but was previously made inoperable is activated and refurbished as necessary. Selected plant entry points are unsealed and prepared for dismantlement. From then on, dismantlement is performed similarly to that previously described except chemical decontamination is not required.

\subsubsection{Layaway Procedures}

After planning and preparation, the layaway operations are divided into six additional major phases:

- chemical decontamination

- mechanical decontamination and fixing of residual radioactivity

- equipment deactivation 
- preparations for surveillance and maintenance

- interim care (surveillance and maintenance)

- final dismantlement

Chemical decontamination and mechanical decontamination and fixing of residual radioactivity for the layaway mode are essentially the same as for the protective storage mode.

Equipment deactivation involves isolation and deactivation of equipment not required to be operated to maintain safety of the facility during the interim care period. Activities are similar to those for protective storage except that more equipment is needed during the interim care period, thus less equipment is deactivated.

During preparations for surveillance and maintenance, high security locks are installed on all exterior doors and on doors leading to highly contaminated areas. Intrusion alarms, fire detection systems, radiation monitoring equipment and ventilation systems are upgraded, installed or renovated, and inspected as necessary to assure safety during the ensuing interim care period.

During interim care, surveillance, maintenance, selected facility operations (e.g., ventilation systems), and security activities are conducted to assure safe confinement of the radioactivity. The facility and total site is kept inaccessible to the public and unavailable for other than nuclear uses. Scheduled programs of radiation effluent and environmental monitoring and periodic inspections are continued.

Final dismantlement is similar to that following protective storage, except that refurbishment of auxiliaries that had been kept operational (e.g., ventilation system, fire, water) is reduced. In addition, fewer sealed access ways require reopening. From that point, the same techniques are used as for immediate dismantlement (except chemical decontamination, which was done previously, is not required). 


\subsection{SAFETY}

Generally conservative estimates were made of the potential safety impacts on the public and on workers from decommissioning the reference fuel reprocessing plant. Events involving and not involving radioactivity were analyzed relative to potential consequences and approximate frequency of occurrence. Radiation exposures from normal operations and potential accidents were investigated for immediate and deferred decommissioning operations, interim care of partly decommissioned facilities, and transportation of radioactive materials. The results are summarized in Table 2.6-1.

The 50-year radiation dose committment to the populace within 80 kilometers (50 miles) from airborne releases from normal decommissioning operations for each decommissioning mode was estimated to be 11 man-rem or less. This radiation dose is a small fraction of the dose from naturally occurring radiation for the affected population. Radiation exposures to members of the public during the interim care period following layaway and protective storage are essentially negligible. All the above radiation doses are low largely because of greatly reduced radionuclide inventories during most of the decommissioning operations and the utilization of efficient process and ventilation filtration systems.

0ccupational radiation doses from initial decommissioning operations were estimated to be 69 man-rem for layaway, 81 man-rem for protective storage, and 512 man-rem for immediate dismantlement. Minimal initial decommissioning and postponement of dismantlement reduces occupational doses by a factor of approximately 1.6 in 30 years, and by a factor of 3 to 3.8 in 100 years. For the effective age of radionuclides assumed in this study, about 16 years out-of-reactor, the overall radiation dose rates generally decrease by a factor of about two for each 30 years of aging.

Radiation doses to members of the public from accidents were found to be quite low. A potential accident that is expected with a medium frequency $\left(10^{-2}\right.$ to $10^{-5}$ per year) is the loss of auxiliary HEPA filters during chemical decontamination of a high-level liquid waste storage tank. This accident is 
stimated to give a 50-year dose commitment of 0.16 rem to the maximum exposed member of the public. Among the worst accidents postulated, a severe earthquake during dismantlement of a high-level waste tank results in a 50-year radiation dose commitment to the maximum individual residing near the site of 8.8 rem; the anticipated frequency of this accident is low (less than $10^{-5}$ per year).

\section{TABLE 2.6-1. Summary of Safety Analysis - Decommissioning} of Reference Fuel Reprocessing Plant

\begin{tabular}{|c|c|c|c|c|c|c|c|c|c|}
\hline \multirow{2}{*}{$\begin{array}{c}\text { Type of } \\
\text { Safety Concern }\end{array}$} & \multirow[b]{2}{*}{ Source of Safety Concern } & \multirow[b]{2}{*}{ Units } & \multirow{2}{*}{$\begin{array}{c}\text { Irmediate } \\
\text { Dismantlement }\end{array}$} & \multicolumn{3}{|c|}{$\begin{array}{l}\text { Protective Storage with Deferred } \\
\text { Dismantlement After }\end{array}$} & \multicolumn{3}{|c|}{$\begin{array}{l}\text { Layaway with Deferred } \\
\text { Dismant lement After. }\end{array}$} \\
\hline & & & & 10 Years & 30 Years & 100 Years & - 10 Years & 30 rears & 100 Years \\
\hline \multicolumn{10}{|c|}{ Public Safety (a) } \\
\hline \multirow[t]{2}{*}{ Radiation Exposure } & $\begin{array}{l}\text { Decommissioning } \\
\text { Operations }\end{array}$ & man-rem & 102 & 82 & $5)$ & 20 & 82 & 51 & 20 \\
\hline & $\begin{array}{l}\text { Transportation } \\
\text { Interim Care }\end{array}$ & $\begin{array}{l}\text { man-rem } \\
\text { man-rem }\end{array}$ & $\begin{array}{l}85 \\
--\end{array}$ & $\begin{array}{l}71 \\
\text { neg }\end{array}$ & $\begin{array}{c}50 \\
\text { neg (b) }\end{array}$ & $\begin{array}{l}21 \\
\text { neg (b) }\end{array}$ & $\begin{array}{l}71 \\
\text { neg (b) }\end{array}$ & $\begin{array}{l}50 \\
\text { neg }\end{array}$ & $\operatorname{neg}^{21}(b)$ \\
\hline \multirow[t]{3}{*}{$\begin{array}{l}\text { Serious Lost-time } \\
\text { Injuries }\end{array}$} & $\begin{array}{l}\text { Decommissioning } \\
\text { Operations }\end{array}$ & no /mode & 17 & 19 & 19 & 19 & 175 & 175 & 175 \\
\hline & Transportation & no /mode & 017 & 017 & 017 & 017 & 017 & 017 & 017 \\
\hline & Interim Care & no /mode & -- & 0033 & 026 & 083 & 040 & 12 & 40 \\
\hline \multirow[t]{3}{*}{ Fatalities } & $\begin{array}{l}\text { Decommiss ioning } \\
\text { Operations }\end{array}$ & no /mode & 00091 & 0010 & 0010 & 0010 & 00096 & 0 ט096 & 00096 \\
\hline & Transportation & no /mode & 0012 & 0012 & 0012 & 0012 & 0012 & 0012 & 0012 \\
\hline & Interim Care & no /mode & -- & 000084 & 00024 & 00081 & 00038 & 0012 & 0038 \\
\hline \multirow[t]{3}{*}{ Radiation Exposure } & $\begin{array}{l}\text { Decommssioning } \\
\text { Operations }\end{array}$ & man-rem & 512 & 426 & 296 & 124 & 423 & 290 & 113 \\
\hline & Transportation & man-rem & 202 & 167 & 116 & 47 & 167 & 116 & 47 \\
\hline & Inter Im Care & man-rem &.- & 18 & 44 & 86 & 128 & 314 & 614 \\
\hline
\end{tabular}

\section{$2.7 \quad$ COSTS}

Table 2.7-1 summarizes the estimated costs in 1975 dollars for the decommissioning modes analyzed in this study. These costs were estimated by the authors and were refined as a result of a review by an architect-engineer. The decommissioning costs are estimated to be $\$ 18$ million for layaway, $\$ 19$ million for protective storage and $\$ 58$ million for immediate dismantlement. The interim care costs following layaway storage and protective storage decommissioning are estimated to be $\$ 680,000 /$ year and $\$ 140,000 /$ year, respectively. Costs for deferred dismantlement after protective storage and layaway are estimated to be $\$ 44$ million and $\$ 43$ million, respectively. 
TABLE 2.7-1. Summary of Estimated Costs for Decommissioning the Reference Fuel Reprocessing Plant

Item
Initial Decommissioning
Surveillance
Deferred Dismantlement
Total Costs (Rounded)

Immediate
Dismantlement

\begin{tabular}{|c|c|}
\hline 58 & 19 \\
\hline-- & 1.4 \\
\hline$=$ & 44 \\
\hline 58 & 64 \\
\hline
\end{tabular}

Estimated Costs in Millions of 1975 Dollars

\begin{tabular}{|c|c|c|c|c|c|}
\hline \multicolumn{3}{|c|}{$\begin{array}{l}\text { Protective Storage With } \\
\text { Deferred Dismantlement After }\end{array}$} & \multicolumn{3}{|c|}{$\begin{array}{l}\text { Layaway with Deferred } \\
\text { Dismantlement After }\end{array}$} \\
\hline $\begin{array}{l}10 \\
\text { Years }\end{array}$ & $\begin{array}{l}30 \\
\text { Years } \\
\end{array}$ & $\begin{array}{l}100 \\
\text { Years }\end{array}$ & $\begin{array}{l}10 \\
\text { Years }\end{array}$ & $\begin{array}{l}30 \\
\text { Years } \\
\end{array}$ & $\begin{array}{l}100 \\
\text { Years }\end{array}$ \\
\hline 19 & 19 & 19 & 18 & 18 & 18 \\
\hline 1.4 & 4.2 & 14.0 & 7.0 & 18.6 & 66 \\
\hline 44 & 44 & 44 & 43 & 43 & 43 \\
\hline 64 & 67 & 77 & 68 & 80 & 128 \\
\hline
\end{tabular}

The breakdown of costs by major cost element is given in Table 2.7-2. The deferral of dismantlement requires additional costs to refurbish auxiliary facilities, to reinstitute a trained decommissioning organization, and to provide a new safety analysis and an additional license application. Also, interim care costs become more significant with time. Other costs of deferred dismantlement are lower than for immediate dismantlement.

Dismantlement of the main process building and the liquid waste storage systems are the most costly, and the plant auxiliaries are the least costly. Thus, from the decommissioning standpoint, there is a major economic incentive to eliminate a liquid waste storage system, which is an optional feature of a fuel reprocessing plant.

\section{TABLE 2.7-2. Decommissioning Cost Distribution}

\begin{tabular}{|c|c|c|c|c|c|c|}
\hline & \multicolumn{6}{|c|}{ Cost, Millions of 1975 Dollars (a) } \\
\hline & \multicolumn{4}{|c|}{ Immediate Dismantlement } & \multirow{2}{*}{$\begin{array}{l}\text { Protective Storage With } \\
\text { Dismantl ement After } \\
30 \text { Years (b) }\end{array}$} & \multirow[b]{2}{*}{$\begin{array}{c}\text { Layaway with } \\
\text { Dismantlement After } \\
30 \text { Years }(\mathrm{b}) \\
\end{array}$} \\
\hline & $\begin{array}{l}\text { Main } \\
\text { Process } \\
\text { Building }\end{array}$ & $\begin{array}{l}\text { Liquid } \\
\text { Storage }\end{array}$ & $\begin{array}{c}\text { All } \\
\text { other }\end{array}$ & Total & & \\
\hline Labor & 5.8 & 6.1 & 4.9 & 16.8 & 21.5 & 28.5 \\
\hline Materials and Equipment & 1.9 & 2.5 & 0.4 & 4.8 & 6.2 & 7.1 \\
\hline Waste Management & 20.1 & 8.3 & 1.8 & 30.2 & 30.8 & 30.8 \\
\hline Subcontracts & 1.8 & 0.4 & 1.4 & 3.6 & 4.1 & 3.8 \\
\hline $\begin{array}{l}\text { Utilities, Taxes and } \\
\text { Others }\end{array}$ & 1.3 & 0.5 & 1.1 & 2.9 & 4.1 & 9.6 \\
\hline Total & 30.9 & 17.8 & 9.6 & $58^{(c)}$ & $67^{(c)}$ & $80^{(c)}$ \\
\hline
\end{tabular}


Cost of management of the wastes from dismantlement amount to about half of the total costs. Of the waste management costs, transportation accounts for about $25 \%$ and disposal costs about $60 \%$. Thus there is a considerable economic incentive to reduce the costs of these two aspects of waste management.

\subsection{WASTES}

Management of wastes (i.e., contaminated equipment and materials, and vitrified chemical decontamination solutions) resulting from decommissioning is an important aspect of decommissioning. Table 2.8-1 gives a summary of wastes from the three disposition modes studied. The relatively large volume of radioactive wastes from decommissioning is such that there is economic incentive for reduction of waste volumes (a factor of about 2 in volume reduction appears possible). Packaging and handling methods exist for these wastes. The volumes of decommissioning radioactive wastes are equivalent to the solid wastes from about 1.6 years of production operations of the reference fuel reprocessing plant. The cost of radioactive waste management, which is a major cost element, is highly dependent upon the ultimate disposition of the waste, i.e., deep geologic disposal or shallow land burial. Thus, there is a major cost incentive to minimize the amount of radioactive waste that must go to geologic disposal.

TABLE 2.8-1. Radioactive Wastes From Decommissioning

\begin{tabular}{|c|c|c|c|c|c|c|c|c|c|}
\hline \multirow[b]{3}{*}{ Disposition of Waste } & \multicolumn{9}{|c|}{ Wastes as Packaged } \\
\hline & \multicolumn{3}{|c|}{ Immediate Dismantlement } & \multicolumn{3}{|c|}{ Protective Storage } & \multicolumn{3}{|c|}{ Layaway } \\
\hline & $\begin{array}{l}\text { Volume } \\
\mathrm{m}^{3}\end{array}$ & Curies & $\begin{array}{l}\text { Disposal } \\
\text { Cost. } \\
\text { Millions } \\
\text { of } \$\end{array}$ & $\begin{array}{c}\text { Volume } \\
\mathrm{m}^{3}\end{array}$ & Curies & $\begin{array}{l}\text { Disposal } \\
\text { Cost. } \\
\text { Millions } \\
\text { of } \$\end{array}$ & $\begin{array}{c}\text { Volumes } \\
\mathrm{m}^{3}\end{array}$ & Curies & $\begin{array}{l}\text { Disposal } \\
\text { Cost. } \\
\text { Millions } \\
\text { of } \$\end{array}$ \\
\hline $\begin{array}{l}\text { Deep Geologic Dis- } \\
\text { posal }\end{array}$ & 4600 & $2.5 \times 10^{7}$ & 23.0 & 210 & $2.5 \times 10^{7}$ & 6.0 & 210 & $2.5 \times 10^{7}$ & 6.0 \\
\hline $\begin{array}{c}\text { Shallow Land } \\
\text { Burial }\end{array}$ & 3100 & $4 \times 10^{3}$ & 1.0 & 180 & $1 \times 10^{3}$ & $\underline{0.05}$ & $\underline{180}$ & $1 \times 10^{3}$ & $\underline{0.05}$ \\
\hline Totals & 7700 & $2.5 \times 10^{7}$ & 24.0 & 390 & $2.5 \times 10^{7}$ & 6.1 & 390 & $2.5 \times 10^{7}$ & 6.1 \\
\hline
\end{tabular}

\subsection{APPROACHES TO FINANCING DECOMMISSIONING}

Three approaches for financing future dismantlement costs have been identified. They are: (1) payment of costs when they are incurred during decommissioning; (2) creation of a sinking fund by annual payments during the 
operating lifetime of the facility; and (3) an initial payment into a trust fund at the startup of the facility. A set of five criteria has also been developed for use in evaluating the desirability of each of the three approaches for providing financial assurance. In approximate order of importance as judged by the authors, these criteria are: (1) the extent to which decommissioning is financially assured; (2) the present value cost of each approach; (3) the extent to which the beneficiaries of the operation of the facility pay for its decommissioning costs; (4) the extent to which the approach facilitates the consideration of decommissioning costs when making selections between alternative power generation systems; and (5) the ease with which the approach can be administered. Based on these criteria and their assumed relative weights, the order of overall desirability is: annual payment sinking fund (2) first, prepayment (3) second, and pay when incurred (1) last.

\subsection{OVERALL COMPARISON OF DECOMMISSIONING ALTERNATIVES}

The primary parameters that affect the selection of a decommissioning alternative are the radiation doses, the economic costs, and the societal aspects of providing surveillance for long periods of time. The total radiation exposures (received mostly by the decommissioning worker) were found to decrease with longer times for deferral of dismantlement. On the other hand, the total cost of immediate dismantlement is lower in constant dollars than for any combination of layaway or protective storage followed by deferred dismantlement.

Thus, there appears to be a constant-dollar economic incentive for immediate dismantlement. Constant-dollar costs for layaway or protective storage followed by deferred dismantlement are about equal for deferral periods up to about 10 years. After about 10 years the high interim care costs for layaway make that option more expensive. Present value costs using typical current interest, inflation and discount rates show a small cost incentive to defer dismantlement for short time periods (about 10 years) and an increasing incentive to defer for longer time periods. After about 15 years the present value costs for protective storage are lower than for layaway as interim decommissioning modes. The societal concerns of requiring 
ong-term surveillance have not been quantified, but these concerns will lend to reduce incentives for long-term deferral of dismantlement.

The dollar cost equivalent of radiation dose (essentially all of it is occupational) can not be evaluated accurately, but it is low.

Manpower commitments are 423 man-years for immediate dismantlement, 188 man-years for protective storage, and 171 man-years for layaway. Deferral of dismantlement increases manpower commitments with time. Total labor starting with protective storage and ending with dismantlement deferred for 10,30 , and 100 years is 481,515 and 634 man-years respectively. Comparable man-years for layaway are 510, 693, and 1338 man-years respectively.

Land area committed to the site following immediate dismantlement is 0 ; following protective storage it is $0.12 \mathrm{~km}^{2}$, and following layaway it is 4.7 $\mathrm{km}^{2}$.

The differences between all other factors studied, such as aesthetic effects, ecological effects and other environmental concerns, etc., appear to be very small among the decommissioning modes studied.

The results of the comparisons are valid for the specific bases, conditions, and assumptions used in this study. The conditions in effect at a specific facility at the time it is decommissioned, including sociological aspects, may alter the results of the study and dictate the choice of decommissioning mode. Therefore, the results and conclusions in this report should be used in the context of the reference site and facility studied and the key bases and assumptions used.

\section{REFERENCES}

1. U.S. Energy Research and Development Administration, Alternatives for Managing Wastes from Reactors and Post-Fission Operations in the LWR Fuel Cycle, Report ERDA-76-43, May 1976, Volume 1, p. 2.70. 
○

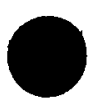




\subsection{DECOMMISSIONING ALTERNATIVES AND STUDY APPROACH}

Once a fuel reprocessing plant has reached the end of its useful operating life, it must be decommissioned, i.e., placed in a condition that future risk to the public from the facility and its site is not significant. A number of alternatives (modes) are possible to satisfy these general requirements for decommissioning. These modes range from minimal initial cleanup requiring continued surveillance and physical security followed by later, more complete cleanup, to immediate complete clean-up and removal resulting in unrestricted public use and access.

This section discusses the decommissioning alternatives evaluated for the fuel reprocessing plant and why these alternatives were selected for consideration in this study. The approach for the evaluation is also discussed. In any generic analysis, certain assumptions must be made in the absence of specific data and/or to permit more general applications of the results. The more important overa11 assumptions or "key bases" for the study and the rationale for their selection are identified.

\subsection{DECOMMISSIONING ALTERNATIVES}

Four basic decommissioning modes (1ayaway, protective storage, entombment and dismantlement) have been identified and their characteristics are summarized in Table 3.1-1 in the order of increasing degree of cleanup.

The latter three modes have been identified and defined in NRC Regulatory Guide $1.86^{(1)}$ for decommissioning nuclear reactors. The definitions in Reference 1 provide the basic descriptions for these three modes. Here they are expanded and interpreted specifically for use in this study. The layaway mode, one that is applicable to a retired FRP, has also been evaluated to broaden the spectrum of decommissioning modes considered. 
TABLE 3.1-1. Decommissioning Mode Characteristics

\begin{tabular}{|c|c|c|c|}
\hline Mode & Facility Status & Contamination Control & Potential Use of Site \\
\hline 1. Layaway & Leave facility in place & $\begin{array}{l}\text { Minimum removal of loose } \\
\text { contamination; operation of } \\
\text { active and passive protec- } \\
\text { tive systems; surveillance } \\
\text { and maintenance required. }\end{array}$ & $\begin{array}{l}\text { Total site unavailable for } \\
\text { other uses. Facility/site } \\
\text { could be returned to its } \\
\text { previous or similar use with } \\
\text { minimal effort. }\end{array}$ \\
\hline $\begin{array}{l}\text { 2. Protective } \\
\text { Storage(a) }\end{array}$ & Leave facility in place & $\begin{array}{l}\text { Remove loose contamination; } \\
\text { provide temporary but rigid } \\
\text { physical barriers; operate } \\
\text { passive protective systems; } \\
\text { surveillance required. }\end{array}$ & $\begin{array}{l}\text { Restricted use of most of } \\
\text { site. Exclusion area } \\
\text { around the immediate facil- } \\
\text { ity is unavailable for other } \\
\text { uses. }\end{array}$ \\
\hline 3. Entombment & Leave facility in place & $\begin{array}{l}\text { Remove loose contamination; } \\
\text { provide hardened permanent } \\
\text { physical barriers; remote } \\
\text { surveillance and periodic } \\
\text { direct surveillance } \\
\text { required. }\end{array}$ & $\begin{array}{l}\text { Unrestricted use of much of } \\
\text { site. Exclusion area around } \\
\text { the immediate facility is } \\
\text { available for other uses, } \\
\text { with restrictions to prevent } \\
\text { compromising the physical } \\
\text { barriers. }\end{array}$ \\
\hline 4. Dismantlement & $\begin{array}{l}\text { Fully decontaminate or } \\
\text { remove facility }\end{array}$ & $\begin{array}{l}\text { Reduce contamination to } \\
\text { unrestricted level; no } \\
\text { surveillance. }\end{array}$ & Unrestricted use. \\
\hline
\end{tabular}
(a) Mothballing is used in Reference 1. In this study, mothballing is considered to be a form of
protective storage.

A11 modes involve removal of loose contamination, and removal and packaging of bulk radioactive materials for disposition offsite. For layaway, the facility is cleaned to some extent, but operation, maintenance and surveillance of both active and passive protective systems are required, including the ventilation system. For protective storage, additional cleanup is performed such that active systems are shut down and the facility is sealed with rigid manmade barriers. Surveillance, operation and maintenance of passive protective systems such as fire, security, and radiation monitoring are continued. For entombment, "hardened" sealing is used to isolate the remaining radioactivity from man. In this case the primary restriction to facility use is that of eliminating activities such as excavating, drilling, or any other means of breaching the barriers that isolate the radioactivity. For dismantlement, cleanup is performed to the extent that all quantities of hazardous materials greater than those acceptable for unrestricted use of the site are removed. Typically much of the facility is removed, and the site is backfilled and restored to a condition near that existing before the facility was constructed. 


\subsubsection{Definition of and Rationale for Layaway}

Layaway is designed to minimize the initial commitments of time, money, and occupational radiation exposure and to temporarily meet the requirements for protection of the public. Modifications to the facility are minimal. Any modifications made are done to ensure the security of the buildings against intruders or to guarantee the continued operation of the active and passive protective systems that assure containment of hazardous materials. Although it is not intended that the plant would be reactivated, that option could be implemented with relatively modest effort. Some reductions in worker exposure in decommissioning operations can be achieved by deferring dismantlement until short-lived fission products decay to relatively low levels (generally 5 to 10 years). In the authors 'opinion, it is unlikely that layaway would extend beyond about 30 years because of maintenance and operational costs.

The reduced initial effort and costs of layway are offset by the need for continuing security, surveillance and maintenance. Security forces as well as electronic surveillance are in full time service. Surveillance devices monitor for intruders, fires and variations in radiation levels, and require periodic inspection and maintenance. Maintenance of the facility ventilation and utility systems, fire protection systems, and outer walls (roof, walls, entry ways) is also necessary. An ongoing program of environmental survei1lance is also assumed to be needed. The duration of interim care of the plant before final decommissioning may vary depending upon the needs of the plant owner, based primarily on economic and safety trade-offs. For example, should the value of the site property for unrestricted use be large and the cost of interim care be also large, there would be incentive to dismantle reasonably soon after layaway. Some incremental occupational radiation exposure would be expended to obtain earlier unrestricted use of the site. (Public concerns and regulatory requirements may also influence the duration of the interim care period.)

After the layaway and subsequent interim care period, several things remain to be done before the facility can be made available for unrestricted 
use. The remaining quantities of long-lived radioactivity that exceed unrestricted release limits will have to be cleaned up, thereby necessitating removal, packaging and disposal of contaminated equipment to a regulated disposal site. Significant amounts of materials and equipment contaminated with transuranic elements and/or major amounts of fission products would be removed and shipped to a Federal repository. Once the remaining radioactive materials are less than the unrestricted release limits, the nuclear facility license can be terminated.

Thus, layaway consists of temporary decommissioning, and is followed by a variable period of interim care. When termination of the nuclear facility license is desired, final dismantlement will be required. The layaway mode appears to be applicable to a multi-facility site where surveillance, security, maintenance and operating capabilities exist, and the possibility exists for continued use of the retired facility in a fashion that complements existing facilities.

\subsubsection{Definition of and Rationale for Protective Storage}

Protective storage is designed to satisfy the requirements for public safety while minimizing the integrated initial and interim care commitments. Modifications to the facility include the installation of rigid physical barriers to ensure the confinement of radioactive and/or other toxic materials and to enhance the security of the buildings against intruders. All active plant operational systems are shut down. Only those passive systems required for safety and surveillance remain in service.

It is not intended that the facility would be reactivated, but this could be done with somewhat more difficulty than for the layaway mode. Reductions in occupational radiation exposure could be achieved by deferring dismantlement following protective storage. This deferred dismantlement could possibly be for longer time periods than are feasible after layaway because of the lower radionuclide inventories, better sealing of radionuclides, and reduced surveillance and maintenance for protective storage. Extended time after protective storage decommissioning appears to be applicable when other nuclear facilities are placed on the same site. 
The increased initial effort and costs of protective storage compared to layaway are offset with time by the decreased need for continuing surveillance and physical security, and by the release of part of the site for other uses under restricted conditions. Electronic surveillance devices are assumed to be in full-time service with off-shift readouts at a local law enforcement office or private security agency. These devices, which would monitor for intruders, changes in radiation levels, and fires, will require periodic checks. Maintenance of the plant outer surfaces (roof, walls, etc.) will be necessary. An ongoing program of environmental surveillance is also assumed to be necessary. The duration of interim care after protective storage decommissioning may vary from a few years to perhaps as long as about 100 years, depending on the desirability to reclaim the site, the degree of public safety afforded by the mode, and the impact of the interim care needs. The timing of further decommissioning will be decided by the facility owner, based primarily on economic and safety trade-offs, with public concerns and/or regulations influencing the choice of action. Some worker radiation exposure penalties are paid because the time period between facility shutdown and dismantlement is shortened.

Several things must be done before the nuclear facility license can be terminated after protective storage and its subsequent interim care period. The remaining quantities of long-lived radioactivity above unrestricted release limits must be cleaned up, removed, and disposed of as in the layaway mode. For a fuel reprocessing plant, the interim care period would be short compared to the time required to allow decay of transuranic and other longlived radioactive materials to unrestricted levels. Thus, significant quantities of contaminated equipment and materials will have to be cleaned and/or removed for offsite disposal. Once these remaining contamination levels are below the unrestricted release limits, the nuclear facility license can be terminated.

In summary, protective storage consists of partial decommissioning followed by a variable period of interim care, perhaps up to 100 years in the authors' opinion. When termination of the nuclear facility license is desired (see Section 4) final dismantlement is required. 


\subsubsection{Definition of and Rationale for Entombment}

Based on the guidance put forth in NRC Regulatory Guide 1.86, entombment of a nuclear reactor facility requires the encasement of the radioactive materials in concrete or other structural materials sufficiently strong and structurally long-lived to assure retention of the radioactivity until it has decayed to levels that permit unrestricted use of the site. The amount and half-life of the residual radioactivity in the facility to be entombed determines the time period that the integrity of the structure must be assured and whether or not re-entry for additional decommissioning is required.

The entombment period for a nuclear facility needed to protect the public may range to hundreds of thousands of years because of long-lived radionuclides. Since a minimum but continuing surveillance program is required under a possession-only license, the assurance of continuing a surveillance and/or maintenance program for such a long time period is highly unlikely. Furthermore, man's ability to design and construct a high integrity surface facility that must last for thousands of years is purely speculative and highly questionable. Prevention of man's intrusion into the entombed facility is likely to be impossible. Past history indicates that the continued existence of institutions or governments may be even less than that for an entombed facility.

Thus it is concluded that the entombed structure must be designed to outlast any radiological or chemical hazard. Unless the structure is to be reentered later and decommissioned further, the potential chemical and radiological hazards should vanish in no more than about 100 years $(a)$ in order to fulfill the bases for entombment.

Entombed facilities are a nuisance subject to vandalism and intentional (but not necessarily malicious) intrusion by man. Any structure conceived by man can also be compromised by him. Extra hardening of entombed facilities such as filling them with concrete will prevent or retard deliberate unauthorized penetration but the facilities will still require some

\footnotetext{
(a) It is the authors' opinion that this time period is preferably less than 50 years for fuel reprocessing plants.
} 
surveillance. It also is difficult to reverse this type of decommissioning if a decision is made later to remove the facility. Provisions for subsequent retrieval of radioactive materials under entombment could be done as an option but this would sacrifice some penetrability protection and would make entombment a variation of protective storage. Furthermore, implementation of the entombment mode would significantly increase the total number of radioactivity-containing sites that require surveillance. This effect would contradict the philosophy of long-term protection of the public and nonproliferation of radioactivity-containing sites.

For a fuel reprocessing plant contaminated to levels above release limits with long-lived transuranic and fission product materials, the structural integrity of the entombed plant must be maintained for unreasonably long time periods. Much of the radioactivity is intinately associated with structural materials and can only be removed physically. The radioactivity will not decay within the assured structural lifetime of the entombed facility. Thus, the basic requirement for entombment cannot be met for many process areas within the facility. Because entombment is basically irreversible with regard to practical further decommissioning, removing long-lived radioactivity in equipment and concrete provides little incentive to entomb anything else at the site. Therefore entombment is not considered a viable decommissioning option for FRPs contaminated with large quantities of transuranic and fission product materials and was not evaluated in this study.

\subsubsection{Definition of and Rationale for Dismantlement}

Dismantlement immediately after plant shutdown is a way to make a site available for unrestricted use within about 5 years following FRP shutdown. The termination of a nuclear facility license occurs in the near term, and long-term security, maintenance, and surveillance needs are elimiriated. To accomplish dismantlement, all contaminated systems are decontaminated, disassembled, removed from the facility and transported to a regulated disposal site. Because this work is performed within a few years after plant shutdown, decay of the residual radioactive material 
will not be as significant as for delayed cleanup modes. Thus more occupational personnel radiation exposure can be expected. The facility structures are decontaminated to unrestricted use levels and either put to some beneficial use or demolished, at the owner's option. In immediate dismantlement, larger initial commitments of money, personnel radiation exposure, and disposal site space (in some cases) are made in exchange for prompt availability of the plant site for other purposes, reuse of plant components, and for the elimination of continuing security, maintenance, and surveillance.

Deferred dismantlement, as might occur at the end of an extended interim care period, perhaps approaching 100 years after layaway or protective storage, is expected to be a somewhat simpler job than immediate dismantlement. Radiation levels within the facility will be reduced, but dismantlement activities will still be controlled by residual radioactivity in plant areas that handled significant amounts of long-lived radionuclides. The potential benefits to be gained by deferred dismantlement, (i.e., lower radioactivity levels with the attendant reduction in dismantlement costs and potentially in occupational radiation exposures, and deferred dismantlement costs) wi11 depend the characteristics of each facility at the time of operational shut-down. These benefits must be weighed against potential disadvantages of deferring dismantlement, i.e. interim care costs, value and need of the reclaimed site, and lack of public acceptance of the interim decommissioned state of the facilities.

\subsubsection{Viable Combinations of Decommissioning Modes}

Figure 3.1-1 illustrates the four decommissioning modes for nuclear fuel cycle facilities and how they might be scheduled for implementation, depending upon timing of and decisions for facility disposition use. From top to bottom on the diagram, the decommissioning modes require increasing fixation or removal of radioactivity. Time increases from left to right on the diagram. Before plant shutdown a decision must be made as to which decomissioning mode will be implemented (at least initially) as shown by the diagonal lines. The possibility of starting with minimum decommissioning activities and allowing for deferral of decisions to do more extensive decommissioning is provided for in all cases except immediate dismantlement.

(There may be some incentives 
defer final decommissioning activities for perhaps as long as about 100 years for fuel reprocessing plants.) Possible decommissioning routes using the entombment mode are shown for completeness with dashed lines, but entombment is not considered to be a viable mode for fuel reprocessing plants, as discussed previously.

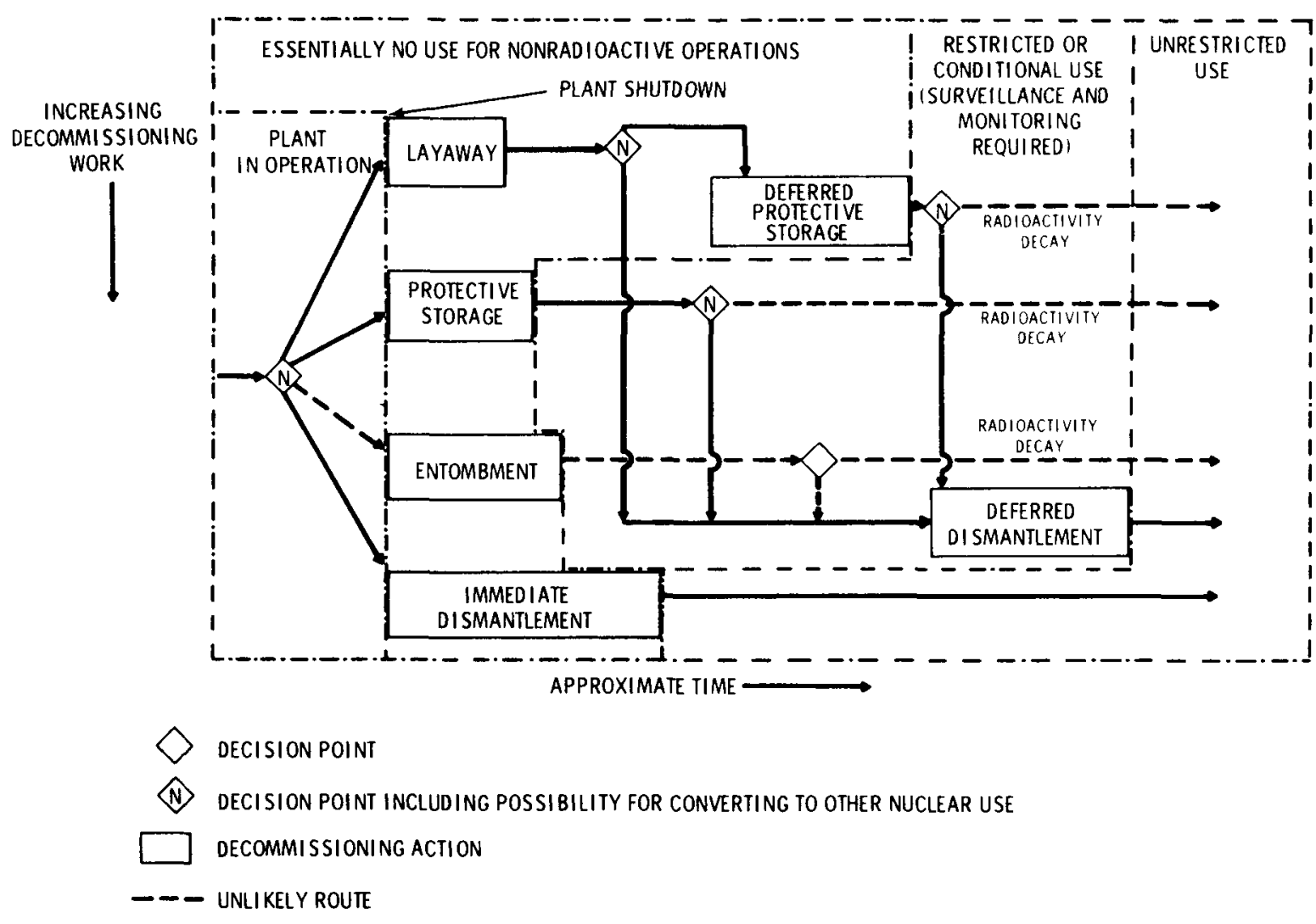

FIGURE 3.1-1. Generalized Decommissioning Pathways and Alternatives for Many Fuel Cycle Facilities

Also shown on the diagram are the general facility/site use categories for the various combinations of decommissioning modes. These use categories are: (1) essentially no non-nuclear use, (2) restricted use, and (3) unrestricted use. For completeness, decommissioning routes from layaway, protective storage, or entombment modes by aging for radioactivity decay to unrestricted use levels are shown with dashed lines, al though these were determined above to be nonviable routes for fuel reprocessing plants. To 
release a fuel reprocessing facility/site for unrestricted use requires dismantlement either immediately after plant shutdown, or after some deferral period.

A potentially viable combination of modes not shown on the diagram is that of dismantlement of part of the facility together with strongly-secured protective storage of the highly radioactive areas. The principal virtues of this combination are: the structures outside of the access barrier are decontaminated, dismantled, and released for unrestricted utilization or for demolition; and highly radioactive sectors and associated components (selected process cells, vessels, pumps, piping, etc.) are left intact, thus reducing personnel radiation exposure. The access barriers could be made sufficiently resistant to intruders that active protection systems would not be required for the contaminated areas. While the initial costs would be larger than for total protective storage, reductions in the interim care costs would be possible, and other beneficial use could be made of the facility/site areas outside the boundary of the secured area. Periodic external inspections of the access barriers and a continuing environmental surveillance program would be required to assure public safety following protective storage decommissioning.

At the end of the interim care period following protective storage decommissioning most radioactivity except transuranic and longer-lived fission products in the process cells will have decayed to levels that require less shielding for dismantlement. It is conceivable that some parts of the plant could be released for unrestricted use and the nuclear facility license terminated. However, in the fuel reprocessing plant the radioactivity is widely distributed so as to make this possibility highly unlikely.

In summary, viable decommissioning routes for a fuel reprocessing plant/ site are:

(1) Dismantlement immediately after plant shutdown, and

(2) Deferred dismantlement following layaway or protective storage options. 
For the latter case, total decommissioning to unrestricted facility use involves two stages of decommissioning separated by a time period of interim care.

\subsection{TECHNICAL APPROACH}

The initial effort was to develop a plan to accomplish the objectives of this study, which are discussed in Section 1. The plan was developed by a team of key personnel with expertise in the primary areas of interest in the study. The areas of expertise included fuel reprocessing plants and their operation, decommissioning techniques, chemical decontamination, chemical and radiological toxicant regulations, safety analyses (including pathways of toxic materials in the environment), operational health physics and cost and benefit estimating and analyses. Consultants and/or non-Battelle experts were utilized to contribute to or review the study results. The resultant approach is shown in simplified form as Figure 3.2-1. The study was then carried out by the same staff or by staff with similar backgrounds.

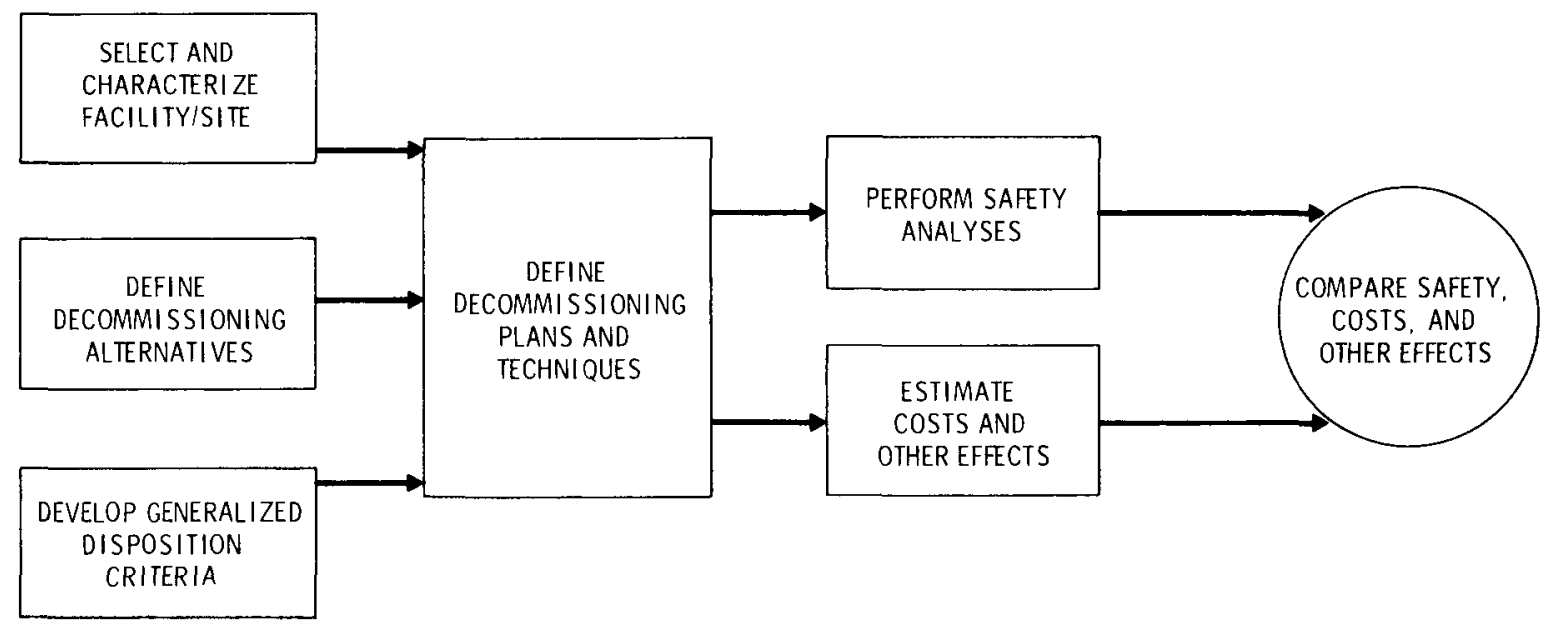

FIGURE 3.2-1. Approach for Decommissioning Study

The first step in conducting the analys is was to select and characterize the reference facility in sufficient depth to perform an engineering and safety analysis of decommissioning a facility. A contemporary specific existing plant was selected for this analysis. An associated plant for solidifying high- and intermediate-level liquid waste was conceptualized as a portion of the facility. 
The total facility was placed on a conceptual generic site which will also be used in similar and related studies of other fuel cycle facilities. A detailed description of the facility was compiled, including development of information such as plant equipment and material sizes, volumes, surface areas, and weights. Pre-decommissioning conditions for the plant and site were defined, including residual radioactivity leve's.

A wide range of viable decommissioning mode characteristics (i.e., layaway, protective storage, and dismantlement) and site use limitations for decommissioned facilities (i.e., nuclear use only, restricted non-nuclear use, and unrestricted use) were selected. Related regulatory guidance was reviewed, summarized, and used as an aid and basis in the study.

Methodology was developed for defining acceptable residual radioactivity levels in facilities and sites for unrestricted use of decommissioned facilities. Radiation dose to the maximum exposed member of the public from the variety of potential pathways through which radionuclides could reach man was the basis for determining these acceptable levels, or "disposition criteria". This methodology was applied to develop example criteria in terms of allowable amounts of residual radionuclides based upon assumed radionuclide mixtures at the plant/site. From these initial criteria, example criteria for restricted use of the decommissioned facilities were developed. These disposition criteria were then used in the analysis to define the extent of decontamination necessary to achieve the planned end use objectives.

Techniques for decontamination of facilities were reviewed. A work and time schedule was developed to conceptually decommission the reference facility for each of the three modes. The techniques utilized were selected on the basis of engineering judgment while maintaining a balance of safety and cost.

Safety analyses were performed for each of the decommissioning modes studied. These analyses included radiological and chemical exposures to the public and to workers for normal decommissioning operations and from potential accidents. Nonradiological industrial accidents to workers 
were also estimated. The safety analyses utilized established data and methodology to estimate the various factors required, such as release mechanisms, dispersion, pathways, and exposure modes of the released materials.

Direct costs of decommissioning were estimated, including labor, materials, equipment, packaging, transportation, disposal, and surveillance costs where applicable. Costs were projected into the future to provide a reference base for estimating future financial requirements. Alternatives for financing decommissioning were examined and compared using example costs from this study. Cost ranges were defined to estimate the sensitivity of the total cost to variations in selected key cost elements.

Al1 of these factors were combined into an overall comparison of their safety-costs-benefits, and advantages and disadvantages for each decommissioning mode.

The study was documented into this report, with Volume 1 containing the main study information and Volume 2 containing supporting details.

\subsection{KEY STUDY BASES}

From the outset a number of important ground rules were established to guide the emphases of the study. These bases were derived from the primary objective of the study--to provide an analysis of safety, costs, and other factors involved in decommissioning a commercial nuclear fuel reprocessing plant. The study is intended to provide background information useful to regulators, plant designers and operators of such facilities. From these objectives the key bases were established for all aspects of the study to assure that the overall study objectives (see Section 1) were achieved. These key bases, listed below, can have major impact on the issues of safety, cost, and time for decommissioning. As stated earlier, many aspects of decommissioning will change with facility locations, specific facility shutdown conditions and residual contamination levels in the plant. The bases and assumptions used in this study must therefore be carefully examined before the results can be applied to a different facility and site. 
1. The study is to yield realistic and up-to-date results. This primary basis is a requisite to meeting the objectives of the study, and provides the foundation for most of the other study bases.

2. The study is to evaluate, in so far as possible, a real and contemporary facility. This basis is an obvious necessity to meet the study objectives and the primary basis above. The facility selected as the reference for study, the Barnwell Nuclear Fuel Plant (BNFP), is felt to satisfy this condition. The BNFP exists (although it has not been operated to date), and appears to represent the general trend in commercial facility features. Where there may be some exceptions to this latter point, the issue is dealt with in the study (e.g., a solidification plant for high-level liquid wastes is conceptually added to the facility as it now exists). The FRP is assumed to be the only nuclear facility on the site.

3. The study is to include an analysis of a spectrum of decommissioning modes. This was done by investigating the layaway, protective storage, dismantlement, and deferred dismantlement modes.

4. Only facilities planned to contain radioactive material and contiguous areas are included in the study. Decommissioning of separate nonradioactive subfacilities is to be accomplished by conventional demolition/ salvage techniques, and is felt to be outside the scope of this study. Radioactivity-containing areas not covered in this study (i.e., conversion of plutonium to plutonium dioxide, conversion of uranium to uranium hexafluoride and interim solid waste storage areas) will be covered generically in other planned decommissioning studies.

5. Current and proven decommissioning technology and techniques are used. Where developmental techniques are applied, they are in an advanced state of development and believed to be ready for the application in this study.

6. A single decommissioning plan is evaluated for each mode analyzed. Where different techniques or assumptions have significant impact on the study results, the effects of alternatives are discussed at least qualitative 
7. The decommissioning plans were selected to provide public/occupational safety in a cost-effective manner.

8. The performance of decommissioning is assumed to be relatively trouble-free; that is, no scheduling or cost allowances were made for unforeseen events that might impede the conduct of the work. This assumption may lead to somewhat optimistic results, but is believed to be achievable with good planning and preparations.

9. It is assumed that the plant process areas have been kept relatively clean during the operating period to allow for easier operational maintenance. As a result, expected contamination levels are generally modest, but should be reasonably consistent with the quality of operation expected in modern commercial facilities.

Accidents that may have occurred during plant operation are assumed to be relatively minor with respect to contamination of normally clean surfaces (e.g., the outsides of process vessels, the soil within the site, etc.). Any major contamination episodes are assumed to have been reasonabiy well cleaned up immediately following the event.

10. The quantity and mixture of radioactive contamination present at plant shutdown is assumed to represent an accumulation of fairly difficultto-clean contamination during operations, thus allowing for decay of accumulated radionuclides. Specifically, contamination inventories are assumed to accumulate at the rate of $1 / 30$ th per year of the total accumulation, for the assumed 30 years of plant operation.

11. A final operational cleanup of the more important inventories of radionuclides is done as part of normal operations, and is not charged to decommissioning. This cleanup is assumed to be routine and similar to those done periodically between normal processing compaigns to improve equipment performance, segregate materials, and to recover materials unaccounted for. Subsequent decontamination efforts are charged to decommissioning. 
12. Decommissioning and radiation protection philosophies and techniques applied conform to the principle of keeping occupational radiation doses as low as reasonably achievable (ALARA).

13. Wastes resulting from decommissioning that contain transuranic radionuclides or significantly large amounts of fission products are assumed to be sent to a Federal repository for deep geologic disposal. Other radioactive wastes are assumed to be sent to regulated burial grounds.

14. The inventory of stored liquid wastes at plant shut.down is assumed to be solidified and charged to plant operations. This inventory is assumed to be from 1.3 years of plant operations, and includes one tank full of high-level waste and one tank half full of intermediate-level waste. The decommissioning of these tanks and the waste solidification system must await the completion of processing these normal operational wastes. The subsequent conversion of liquid wastes from decontamination of the plant in the waste solidification facility is charged as part of decommissioning.

From these major study bases, more specific bases and assumptions were derived for specific study areas. These latter bases and assumptions are presented in the respective report sections where they are used.

\section{REFERENCE}

1. U.S. Atomic Energy Commission Regulatory Guide 1.86, Termination of Operating Licenses for Nuclear Reactors, June 1974. 


\subsection{REGULATORY AND SAFEGUARDS CONSIDERATIONS}

In the development of a viable plan for decommissioning a nuclear facility such as a Fuel Reprocessing Plant (FRP), consideration must be given to the regulations that exist to assure public and occupational safety during such operations. Additionally, because of the anticipated presence of special nuclear material (SNM) in shutdown FRPs, consideration must be given to the necessity and methods for safeguarding the material. The following two sections discuss these issues in general and as they apply in detail to the reference FRP.

\subsection{EXISTING REGULATIONS, STANDARDS, AND GUIDES}

The purpose of this section is to identify existing regulations, standards, and guides that generally apply to decommissioning activities, highlight the main points, and address how they can be interpreted to apply to the decommissioning of an FRP. Additionally, areas are identified where guidance is lacking or where the application of existing guides to an FRP is unclear.

Currently no regulatory standards or guides exist that uniquely address the constraints on a licensee of an FRP before, during and after the decommissioning of his facility and site. Guidance on methods and procedures acceptable to the Nuclear Regulatory Commission (NRC) for terminating operating licenses for nuclear reactors is found in Regulatory Guide 1.86, Termination of Operating Licenses for Nuclear Reactors. The rationale for public protection defined in this guide for decommissioning reactor facilities is presumed to be applicable to an FRP. NRC does have guidance for facilities other than reactors, in the form of a procedure to assist in internal reviews for license terminations, entitled "Guidelines for Decontamination of Facilities and Equipment Prior to Release for Unrestricted Use or Termination of Licenses for Byproduct, Source, or Special Nuclear Material", November 1976. Additionally, many of the activities (i.e., transportation, occupational safety, etc.) that take place during decommissioning are similar to activities in other components of the nuclear fuel cycle. These activities are controlled by existing regulations. 
Review of these regulations has been divided into activities a licensee would expect to encounter during decommissioning of his plant. This division is typical of the three basic decommissioning phases; planning and preparation, decommissioning, and interim care.

Users of information from this section should recognize that regulations and guidelines in this area tend to be dynamic. National policy relating to the LWR nuclear fuel cycles is changing and Federal reorganizations in the energy area are forthcoming, possibly accentuating this changing status. The information found in Section 4.1 reflects the status of the regulations and Federal guidelines as of August 1977 and can only be used as a departure point for future application.

\subsubsection{Regulations Pertaining to the Planning and Preparation Phase}

Prior to terminating the operation of an FRP, the licensee will decide on the final disposition of the facility (with approval of NRC) and plan how to accomplish that end point. A key consideration upon plant shutdown is the termination of the operating license regulated by 10 CFR 50 Licensing of Production and Utilization Facilities. Section 50.82, "Application for Termination of Licenses" specifies the requirements that must be satisfied to terminate an operating license. Regulatory Guide 1.86 describes methods acceptable to NRC for satisfying the requirements of Section 50.82. Although specifically addressing nuclear reactors it does, in principle, apply to an FRP.

A licensee will request amendment of his operating license to allow him to possess radioactive and/or special nuclear materials but not operate the facility in a production mode. Because of the nature of some of the decommissioning activities anticipated at the site, NRC may elect to issue a possession-only license with administrative controls and facility requirements appropriate for the decommissioning option selected. Although this appears consistent with Regulatory Guide 1.86, it is possible that a modified operating license will be issued rather than a possession-only license. The rationale behind this logic is that although the plant operating functions have changed significantly during decommissioning, many unit operations may be 
similar (i.e., chemical decontamination, waste treatment and solidification). There will be active operations conducted in the plant involving radioactive material and utilizing of existing systems and components that will result in release of effluents to the environment. Additionally, unplanned releases of radioactive material are possible from accidents during decommissioning. Title 10 CFR Part 50 Section 50.59, "Authorization of Changes, Tests and Experiments" and Section 50.90, "Application for Amendment of License or Construction Permit" provides the rules by which a licensee may amend his 1icense. This amended state of facility license results from NRC approval to amend requirements in the technical specifications that are applicable to normal facility operations. It appears that the necessary requirements to assure public safety during decommissioning can be covered whether or not the license is a modified-operation or a possession-only license.

As part of the amended license, the licensee must have authorization for special nuclear material (10 CFR Part 70, Special Nuclear Materials), byproduct material (10 CFR Part 30, Rules of General Applicability to Licensing of Byproduct Material) and source material (10 CFR Part 40, Licensing of Source Material) until the radioactive material and any source and special nuclear material are removed from the facility. The specific requirements of the amended license and the degree of applicability of the above regulations will be dependent upon the quantities of plutonium and other SNM or source material remaining in the process systems.

Consistent with the intent of 10 CFR Part 51, Licensing and Regulatory Policy and Procedures for Environmental Protection, before decommissioning begins, an environmental impact statement or environment impact appraisal will have to be prepared describing the probable effects of the proposed decommissioning actions. These requirements are defined in Section 51 , subpart A. Section 51.5.b(7) states that license amendments or other orders authorizing decommissioning of an FRP may or may not require an impact statement of such planned actions. If judged that an impact statement is not required, a negative declaration $(a)$ and an environmental impact appraisal must be prepared

(a) A negative declaration is a document prepared by the NRC that states that the NRC has decided not to prepare an environmental impact statement for a particular action, and that an environmental impact appraisal setting forth the basis for that determination is available for public record. 
in accordance with Section 51.7 and $51.50(d)$. Guidance is provided to NRC the need for an impact statement by the Council on Environmental Quality Guidelines, 40 CFR 1500.6.

During the design and planning stage for building a new or modifying an existing nuclear facility such as an FRP, a construction permit must be obtained from NRC consistent with the requirements of 10 CFR Part 50, Sections 50.23 and 50.30, which define the content of license applications. As part of this application, Section 50.30 ( $f$ ) requires that an environmental report be prepared to determine if construction (10 CFR 51, Subpart B Section 51.20) or operation (10 CFR 51, Subpart B Section 51.21) of the facility will have significant impact on the environment. Additionally, as part of this application, a safety analysis report must be prepared, the contents of which are defined in Section 50.34. Neither of these reports requires plans of the final disposition of the facility or an analysis of the impact of implementing any of the possible decommissioning modes suggested by Regulatory Guide 1.86. Even though an analysis of the probable safety and environmental effects of retiring nuclear facilities are not specifically required at the time of construction permit and license applications, the regulations of Part 50, namely Section 50.82, do assure adequate consideration of public safety upon termination of the operating license.

In addition to Regulatory Guides, NRC has internal guidance for their staff on how safety analysis reports and environmental impact statements should be evaluated. These guides are found in NUREG-75/087, Standard Review Plans for the Review of Safety Analysis Reports for Nuclear Power Plants (September 1975) $^{(7)}$ and NUREG-0158 Environmental Standard Review Plans for the Environmental Review of Construction Permit Applications for Nuclear Power Plants (Draft) (January 1977). (2) Even though the guides specifically apply to nuclear reactors, the philosophy and methods acceptable to NRC apply generally to FRPs and to decommissioning activities. Decommissioning is addressed in the draft of the Environmental Standard Review Plans (ESRP), NUREG-0158 Section 10.2.3 (in preparation).

An important area considered by NRC during a review of a license application is the financial qualification of the licensee. Regulations covering 
this area are found in Section 50.33(f) and Part 50, Appendix F.5. The latter regulation is an elaboration of the former, specifying that the license application shall include information to show that the applicant is financially qualified to provide for the removal and disposal of radioactive waste during operation and upon decommissioning of the facility. Section 50.33(f) addresses the necessity of sufficient funds to operate the facility for the period of the 1 icense or 5 years, whichever is greater, plus the estimated cost of permanently shutting the facility down and maintaining it in a safe condition. The latter regulation does not totally address decommissioning of the facility.

Currently, no regulation specifically requires a detailed decommissioning plan. Regulatory Guide 1.86 may be loosely interpreted to imply that one is needed; it states that NRC will impose requirements depending on the decommissioning option selected. It is the authors' feeling that such a plan, namely, a Master Decommissioning Plan (MDP) should be required and included as part of the amended license. The MDP should include the decommissioning objectives for the facility/site, safety analys is and procedures, safeguard plans, emergency plans for unplanned events postulated to occur, and a time schedule.

As part of this plan, quality assurance $(Q A)$ of the decommissioning should be addressed "... to prevent or mitigate the consequences of postulated accidents that could cause undue risk to the health and safety of the public" (Part 50, Appendix B, "Quality Assurance Criteria for Nuclear Power Plants and Fuel Reprocessing Plants"). The requirements in Appendix B pertain to design, purchasing, fabrication, etc., and do not specifically address decommissioning. A proposed ANSI standard (ANSI N46.2.12-1976) Requirement for Auditing of QA Programs for Nuclear Fuel Reprocessing Facilities also addresses the operating FRP but not decommissioning. Guidance is also found on acceptable QA plans for an FRP in Regulatory Guide 3.3, Quality Assurance Program Requirements for Fuel Reprocessing Plants and for Plutonium Processing and Fuel Fabrication Plants, and for nuclear facilities in NRC's Standards Review Plans 17.1, "Quality Assurance During Design and Construction" and 17.2 "Quality Assurance During the Operating Phase". The principles and objectives of such guidance should apply to all activities of decommissioning. 
Therefore, applicable portions of Appendix B, Regulatory Guide 3.3, and SRP 17.1 and 17.2, should be used to develop a QA plan for inclusion in the license amendment and the MDP.

Other considerations of significant concern, mainly to the licensee, are the amount of the annual license fee and the facility insurance premiums required to satisfy regulations during the decommissioning and interim care periods. Neither of these items has been adequately addressed relative to decommissioning; they are, however, dictated by the type and quantity of radioactive and/or special nuclear materials, the type of activities being conducted, and correspondingly the type of license regulating the activities. Licensing fees are addressed in 10 CFR, Part 170; the schedule of fees for production and utilization facilities (Part 50 license) is in Section 170.21. The requirements for financial protection and indemnity agreements are provided in $10 \mathrm{CFR}$, Part 140 . The levels of protection required for an FRP during decommissioning is not specifically defined.

\subsubsection{Regulations Pertaining to the Decommissioning Phase}

Once a decommissioning mode has been selected for an FRP and the Part 50 license has been modified, the actual decommissioning activities can be initiated. Section 50.82 and Regulatory Guide 1.86 identify decommissioning options considered acceptable to NRC for nuclear reactors. Although the interpretations of some of the definitions are expanded and the term "mothballing" is not used in this study, these same alternative modes have been considered in this study as viable options (with exception of entombment) for decommissioning an FRP.

The facility will be placed in the planned disposition mode according to the Master Decommissioning Plan. Currently, there is a major trend toward placing more emphasis on designing and constructing facilities to more easily accommodate decommissioning. Design criteria specific to this purpose for an FRP are given in ANSI Standard N300-1975 Design Criteria for Decommissioning of Nuclear Fuel Reprocessing Plant. (a) Additionally, 10 CFR Part 50, Appendix F, addresses NRC's policy relating to siting of reprocessing plants. Appendix F.4 indicates that a design objective for an FRP should be to (a) It should be noted, however, that the NRC has not endorsed the provisions ANSI N300-1975. 
facilitate decontamination and removal of significant radioactive wastes at the time of decommissioning. This policy is aimed at a concern about proliferation of nuclear sites.

During the period from plant shutdown and until quantities of radioactive materials and/or special nuclear materials that require safeguards and other regulatory control are removed from the facilities, special safeguards and security precautions must be taken. It is expected that such precautions will differ from those in force during normal operation because of the reduced inventory and because of the changing status of the facility during decommissioning. Such precautions are to protect the plant from acts of industrial sabotage and to guard against the theft of SNM. Regulations defining required precautions are found in 10 CFR Part 70 Special Nuclear Materials and 10 CFR Part 73 Physical Protection of Plant and Materials. They generally apply to decommissioning of an FRP by nature of the residual plant inventories at time of shutdiown.

Considerations relating to safeguarding of SNM during the decommissioning of an FRP as well as the applicable regulations for physical protection and accountability are discussed in detail in Section 4.2 of this report, Safeguards Considerations. Other applicable regulations and guidelines are listed below.

- 10 CFR 50.34(a) requires including a physical security plan in license application and amendment

- Regulatory Guide 5.52, Standard Format and Content for the Physical Protection Section of a License Application"

- Standard Review Plan(a) 13.6, Industrial Security

- Regulatory Guide 1.17 Rev. 1, Protection of Nuclear Power Plant Against Industrial Sabotage

- Regulatory Guide 5.7, Control of Personnel Access to Protected Areas, Vital Areas and Material Access Areas

- Regulatory Guide 5.10, Selection and Use of Pressure Sensitive Seals on Container for Onsite Storage of Special Nuclear Material

(a) NRC Standard Review Plan, NUREG 75/087 
- Regulatory Guide 5.12, General Use of Locks in the Protection and Control of Facilities and Special Nuclear Materials

- Regulatory Guide 5.14, Visual Surveillance of Individuals in Material Access Areas

- Regulatory Guide 5.15, Security Seals for the Protection and Control of Special Nuclear Material

- Regulatory Guide 5.20, Training, Equipping, and Qualifying of Guards and Watchmen

- Regulatory Guide 5.27, SNM Doorway Monitors

- Regulatory Guide 5.43 , Plant Security Force Duties

- ReguTatory Guide 5.45, Standard Format and Content for the Special Nuclear Material Controls and Accounting Section of a Special Nuclear Material License Application

- Regulatory Guide 5.57, Shipping and Receiving Control of Special Nuclear Materials

- ANSI, Standard N15.26-1976, Physical Protection of Special Nuclear Material Within a Facility

- ANSI, Standard N18.1-1973, Industrial Security for Nuclear Power Plants

- 10 CFR 70 and 73, Physical Protection of Plants and Materials, Performance Oriented Safeguards Requirement (Proposed, Federal Register, Volume 42, No. 128, page 34310, June 5, 1977) and Upgrading Guard Qualification Training and Equipment Requirements (Proposed, Federal Register, Volume 42, No. 128, page 34321 , June 5, 1977).

During the actual decommissioning of the FRP, regardless of the mode selected, radioactive waste will be accumulated, treated, packaged, stored, and transported to one or more disposal sites. This includes the solidification of radioactive liquid waste from decontamination flushing solutions and high-level liquid waste heels from prior FRP operations (treatment of heel in the waste tank is considered part of the decommissioning activities). Regulations 
defining the requirements to assure safety of the public and occupational workers from such waste-related activities are found in 10 CFR Part 50, Licensing of Production and Utilization Facilities, 10 CFR Part 50, Appendix F, Policy Relating to the Siting of Fuel Reprocessing Plants and Related Waste Management Facilities, 10 CFR Part 20, Standards for Protection Against Radiation, and 10 CFR Part 71, Packaging of Radioactive Materials for Transport and Transportation of Radioactive Material Under Certain Conditions. Means for compliance with these regulations, including those for safeguards and security precautions will be defined in the specifications and plans of the amended license at the start of decommissioning. These are the same requirements, although perhaps to a lesser degree in some areas, that the licensee would have to address in his application to construct and operate an FRP.

The decommissioning of an FRP will entail the disposal of residual radioactive materials, components contaminated with major amounts of transuranic elements and fission products, and materials contaminated with low levels of these various radionuclides. Detailed procedures for the disposition of these wastes must be clearly defined in the license application. Guidance on acceptable methods for control of plutonium contaminated materials can be found in NRC Regulatory Guide 5.47, Control and Accountability of Plutonium in Waste Material.

Currently little guidance exists on the final disposition of some of the types of waste anticipated from decommissioning an FRP. This includes the transuranic-contaminated waste and the highly contaminated pieces of equipment. Shallow land burial of these wastes is currently being reviewed. A decision to require deep geologic disposal of these wastes could have a sizeable cost effect on the licensee because of the major difference in cost between shallow land burial and deep geologic disposal in a Federal repository. A review of the Federal regulations pertaining to the licensing and operation of commercial and ERDA-owned waste management facilities has been recently completed

The radioactive effluents from waste processing operations or other activities during decommissioning must comply with Environmental Protection Agency regulations as well as 10 CFR Part 20. Currently, no specific EPA 
regulations exist for decommissioning. The EPA's $25 \mathrm{mrem} / \mathrm{yr}$ limit of exposure to the maximum exposed member of the public from the nuclear fuel cycle, defined in 10 CFR Part 190, Proposed Environmental Radiation Protection Standards for Nuclear Power Operation, excludes waste management activities but such limits are now being developed. It is anticipated that a waste management limit similar to the $25 \mathrm{mrem} / \mathrm{yr}$ fuel cycle limit will be developed by EPA. This new limit will probably include the impact of decommissioning.

The NRC is now in the process of developing comprehensive waste management regulations that will include wastes from decommissioning. Regulatory authority of decommissioned facilities in Agreement States is relinquished to the States. Since Section 274(b) of the Atomic Energy Act of 1954, as amended, requires Agreement State programs to be compatible with NRC regulations, the NRC will require that Agreement State programs reflect NRC's lead in the area of decommissioning.

Packaging of the decommissioning wastes will be dictated by their storage and/or ultimate disposal mode. Requirements for the packaging of the radioactive material are also defined by transportation regulations. Regulations governing the transport of radioactive materials have been established to prevent the loss or dispersal of material during shipment and to assure the safety of the public and the transportation workers. There is overlapping responsibility for regulating the safe transport of radioactive materials. Primary responsibility at the Federal level lies with the Department of Transportation (DOT) Material Transportation Bureau and the Nuclear Regulatory Commission (NRC).

A "Memorandum of Understanding" between these latter two agencies was signed in 1966 and revised in 1973. (4) This memorandum calls for cooperation between DOT and NRC and delineates the responsibilities of each agency. The DOT is responsible for promulgating and enforcing safety standards governing packaging and shipping containers and for the labeling, classification, and marking of all packages. The DOT also implements safety standards for the mechanical condition of carrier equipment and qualifications of carrier personnel. The NRC develops performance standards for package designs and reviews 
package designs for Type B, fissile and large quantity packages. The DOT requires NRC approval to use these packages. (5) The Federal Aviation Administration (FAA), the Interstate Commerce Commission (ICC), and the U.S. Coast Guard also exercise some regulatory authority over the shipment of radioactive materials.

The transportation or packaging for transport of radioactive material is subject to issuance of the appropriate licenses. Applicants for a license to package or to transport radioactive material must show by a combination of analysis and experiments that the proposed package or transport vehicle satisfies all the requirements set forth in the Code of Federal Regulations. The application must describe proposed controls or precautions to be used in the loading, unloading, handling and transport of radioactive material, and the procedures to be followed in the event of an accident or delay in shipment. Inspection and accountability procedures must also be described.

The following Federal Regulations are applicable to the transport of radioactive materials:

- Title 49 Code of Federal Regulations Parts 170-199 (49 CFR 170-199) Department of Transportation regulations governing the transport of hazardous materials.

- 10 CFR 71 - Nuclear Regulatory Commission regulations governing the packaging and shipment of radioactive materials.

- 14 CFR 103 - Federal Aviation Administration regulations for shipment of radioactive materials by air.

- 47 CFR 146 and 149 - U.S. Coast Guard regulations governing the shipment of radioactive materials by water.

- 10 CFR 73 - Nuclear Regulatory Commission regulations for the protection of special nuclear material in transit.

The DOT and NRC regulations are the most important for shipments made during the decommissioning of nuclear facilities. 
Although Federal agencies dominate the regulatory process for the transport of radioactive materials, state governments also exercise some control over these shipments. State highway departments regulate gross vehicle weights, vehicular dimensions and other parameters for radioactive shipments just as they do for other kinds of shipments. Currently, about half of the states have adopted the U.S. DOT Hazardous Materials Regulations to cover intrastate shipments. Several states have adopted or proposed additional regulations concerning radioactive materials. $(4,6)$ These include:

- special routing of radioactive shipments

- advance notification for shipments of large quantities of materials

- state inspections of some types of radioactive shipments

- prohibition of certain types of shipments within the states

- prior approval for radioactive shipments

- requirements of exclusive vehicle use for radioactive shipments

- use of pilot vehicles

- speed restrictions for radioactive shipments

- specific hours of movement

- accompaniment of all shipments by radiation monitoring personnel.

The variation of regulations between adjacent states can often require special considerations for interstate shipments.

There is a potential conflict between some of the proposed state laws and the provisions of the National Transportation Act of 1974 (Public Law 93-633 signed in 1975). This law prohibits the states from adopting laws or regulations more stringent than Federal regulations unless the state regulations improve transportation safety. Even in this case, such rules can be adopted only if they do not unreasonably burden commerce.

A more detailed review of the regulations pertaining to the transport of radioactive material can be found in ERDA-76-43, Volume 5, Appendix E Alternatives for Managing Waste from Reactors and Post-Fission Operations in the LWR Fuel Cycle, May 1976. 
Regulations were discussed previously that address the control of effluents from decommissioning activities. Because of the anticipated high radiation sources and contaminated work locations, occupational safety is also of major importance during decommissioning. Radiation protection to workers is regulated by 10 CFR Part 20. Section 20.101 defines the exposure limits. These limits have recently been changed to reflect the operating philosophy of ALARA (As Low As is Reasonably Achievable).

NRC describes this operating philosophy in Regulatory Guide 8.8 "Information Relevant to Maintaining Occupational Radiation Exposure as Low as Practicable (Nuclear Reactors)" and Regulatory Guide 8.10 "Operating Philosophy for Maintaining Occupational Radiation Exposure as Low as is Reasonabiy Achievable". Although not specifically cited for application to decommissioning activities, the guides are definitely meant to apply.

Additional information can be found on how to comply with the ALARA concept in the NRC Standard Review Plan, Section 12.1 "Assuring that Occupational Radiation Exposures are As Low As is Reasonably Achievable". Some of the more relevant regulation and guidance cited in this document are given below:

- 10 CFR Part 19, Notices, Instructions and Reports to Workers; Inspections

- 10 CFR Part 20, Standards for Protection Against Radiation

- Regulatory Guide 1.8, Personnel Selection and Training

- Regulatory Guide 1.16, Reporting of Operating Information

- Regulatory Guide 1.39, Housekeeping Requirements for Water Cooled Nuclear Power Plants

- Regulatory Guide 8.2, Guide for Administrative Practices in Radiation Monitoring

- Regulatory Guide 8.3, Film Badge Performance Criteria.

- Regulatory Guide 8.6, Standard Test Procedures for G-M Counters

- Regulatory Guide 8.7, Direct Reading and Indirect Reading Pocket Dosimeters

- Regulatory Guide 8.8, Information Relevant to Maintaining Occupational Radiation Exposures as Low as Practicable (Nuclear Reactors) 
- Regulatory Guide 8.9, Acceptable Concepts, Models, Equation and Assumption for a Bioassay Program

- Regulatory Guide 8.15, Acceptable Programs for Respiratory Protection

- Regulatory Guide 8.XX, Control of Radioactive Surface Contamination of Material, Equipment and Facilities to be Released for Uncontrolled Use (in preparation)

- ANSI N18.9-1972, Administrative Controls for Nuclear Power Plants, American National Standards Institute (1972)

- ANSI Z88.201969, Procedures for Respiratory Protection, American National Standards Institute (1969)

- USBM-23, Respiratory Protective Services for Use in Atmospheres Containing Radioactive Materials, U.S. Bureau of Mines (1973)

One of the goals of decommissioning a nuclear facility is to avail the land for other uses if desired. In order to release the facility and/or site for unrestricted use, the residual radioactive contamination must be at a level acceptable for public protection. Several attempts have been made to define the permissible levels of residual radioactivity. In this report, a methodology for determining the criterion is based on dose and is applied to the reference FRP. Other major guidance is found in Regulatory Guide 1.86 and the proposed ANSI Standard N328 Control of Radioactive Surface Contamination on Materials, Equipment and Facilities to be Released for Uncontrolled Use. (a) Previously mentioned guidance that NRC uses for terminations of byproduct, source, and special nuclear material licenses (similar to Regulatory Guide 1.86) contains a table of "Acceptable Surface Contamination Levels" identical to that in Regulatory Guide 1.86.

Additional guidance can be inferred from information developed for plutonium in soils. $(7,8)$ The EPA is also in the process of finalizing their guidance for the environmental limits of plutonium contamination in soils for unrestricted use.

(a) The NRC supports the provisions of this standard. 
During decommissioning activities at an FRP, normal industrial (nonradiation related) safety regulations governing occupational work conditions are provided by Title 29 Code of Federal Regulations, Parts 1900 to end (Occupational Safety and Health Administration, Department of Labor).

\section{Interim Care Phase}

This phase primarily deals with surveillance and maintenance of the facility after it is in a decommissioned mode other than total dismantlement. Primary concerns during this period are to assure public safety and safety of the staff maintaining the facility. The facility may contain amounts of special nuclear and/or other radioactive material that requires safeguards or other regulatory control. Applicable regulations governing all of these points have been previously discussed.

During this period, the license may need to be amended consistent with the inventory of special nuclear material and the level of potential public safety concern the facility represents. A possession-only license is likely in the case of an FRP.

If dismantlement follows the interim care period, the requirements discussed in the decommissioning phase would apply. Following dismantlement, termination of the license could then occur consistent with the guidance offered by Regulatory Guide 1.86 .

\subsection{SAFEGUARDS CONSIDERATIONS}

Prior to initiating decommissioning of a nuclear facility such as a FRP, consideration must be given by the licensee to the necessity of safeguarding the quantities of residual special nuclear material (SNM) anticipated to be found in the facility following normal operational clean-out flushes. Regulations for operating facilities containing values of SNM that require regulatory control require internal material controls and special statistical methods for accounting for the SNM (both in process and storage) and tamper-proof physical protection systems for guarding the material against diversion and sabotage.

The problem of safeguarding SNM in a facility during decommissioning is unlike that in an operating facility. During decommissioning, the SNM will be Contained in chemical flushing solutions, on the surfaces of process cell walls 
and equipment, in sumps, distributed in waste and rubble, and generally in inaccessible places. Basically, the easily removed SNM would be recovered during the operational cleanup. Current regulations do not distinguish between SNM in a relatively concentrated and more accessible form, like in an operating facility, and similar amounts of SNM in the highly dispersed and dilute form expected in decommissioning activities. Since SNM in the latter form is likely to be difficult to remove and concentrate in significant quantities, it is probably not an attractive target for theft or sabotage. For this reason, the requirements for safeguarding SNM during decommissioning should reflect this significant difference.

The requirements governing the safeguarding of SNM and nuclear facilities are contained in Title 10 CFR Part 70 Special Nuclear Material and Part 73 Physical Protection of Plants and Materials. Although decontamination and decommissioning operations are not mentioned specifically in these regulations, the existing provisions of Parts 70 and 73 apply to such operations if and when the licensee comes into the possession of SNM unless the NRC grants a specific exemption to the licensee.

The licensed operator of the FRP will have established a final cumulative special nuclear Material Unaccounted For (MUF) value as a result of a closeout of the last accounting period. In the event that the production operator cannot reduce the MUF of SNM to a value that is insignificant with respect to the uncertainties in measurement, it can be anticipated that the organization conducting the decommissioning will have to implement procedures to recover and account for any operational MUF carried over to decommissioning operations. It is also anticipated that the FRP operating licensee will still be required by NRC to maintain responsibility for the facility and the SNM during decommissioning even though an independent contractor may be performing the work. As indicated in Section 4.1, a revision to the operating license defining these requirements is expected to be required, probably in the form of a modified fundamental nuclear material control plan and physical security plan.

Even if MUF is statistically insignificant at the time of facility shutdown, the process of decommissioning may result in recovery of significant 
quantities of SNM from contaminated equipment and structures. Therefore, a safeguards program will be needed to define and govern the protection, control, accountability, reporting and disposal of SNM found in the facility during decommissioning activities. The specific safeguards requirements for each quantity and type of SNM will be determined by the NRC during the licensing process. Because of the anticipated small quantities of SNM, the way it is distributed, and its general lack of accessibility, it is anticipated that safeguards programs required for decommissioning will be significantly less stringent than for normal operations.

As previousiy stated, during the decommissioning activities in the facility, it is expected that many of the regulations that apply specifically to the operation of a FRP will not be applicable. Strict interpretation of these requirements to the needs for safeguarding SNM during decommissioning may be unnecessarily restrictive. These regulations, as well as others are meant to apply to bulk or concentrated quantities of SNM normally found in operating facilities. In order to maintain a uniform level of public protection, such regulations should necessarily be relaxed when applied to decommissioning. However, compliance should still be maintained with the intent and principles of these regulations. A summary of the regulations judged to be relevant (either in total or in part) for the control of SNM during decommissioning activities is given below.

1) If the licensee possesses at one facility any SNM not in sealed source form, he will be required to maintain records (of a form approved by the NRC) of the quantities of SNM acquired, transferred, disposed of, and on inventory. The licensee must also protect the facility against sabotage and theft of SNM. If the licensee receives or transfers one gram or more of SNM to another licensee he must, in addition to the above, file a SNM transfer form (Form 741) with the NRC and the transferer or receiver.

2) If the 1 icensee possesses $350 \mathrm{~g}$ or more of SNM at one facility, he must file a status report (Form 742) with the NRC twice year and take a physical inventory of his SNM holdings once a year. 
3) If the licensee possesses more than one effective $\mathrm{kg}$ of $\mathrm{SNM}(\mathrm{a})$ at one facility, he must maintain, in addition to the above, an approved and documented set of SNM control and accounting procedures satisfying the requirements of Section $70.51,70.57$, and 70.58 of 10 CFR Part 70 . The SNM must be at a11 times in the physical custody or control of a designated custodian, all transfers between custodians must be documented, periodic inventories must be taken as specified in Section 70.51, and the status of the material balance reported to NRC at those specified times. Detailed records of all SNM transactions and inventories are also required.

4) Each 1icensee authorized to possess SNM in a quantity exceeding $700 \mathrm{~g}$ of contained ${ }^{235} \mathrm{U}, 520 \mathrm{~g}$ of ${ }^{233} \mathrm{U}, 450 \mathrm{~g}$ of plutonium, $1,500 \mathrm{~g}$ of contained $235 \mathrm{U}$ if no uranium enriched to more than $4 \%$ by weight of $235 \mathrm{U}$ is present, $450 \mathrm{~g}$ of any combination thereof, or one-half such quantities if massive moderators or reflectors made of graphite, heavy water or beryllium may be present, shall maintain a monitoring system for nuclear criticality meeting the requirements of Section 70.24 of Title 10 of the Code of Federal Regulations.

5) If the 1 icensee possesses or uses ${ }^{235} U$ contained in uranium enriched to $20 \%$ or more in the ${ }^{235} \mathrm{U}$ isotope, ${ }^{233} \mathrm{U}$, or plutonium, or any combination of these materials, which totals $5 \mathrm{~kg}$ or more as computed by the formula, $\mathrm{kg}=\left(\mathrm{kg}\right.$ contained $\left.{ }^{235} \mathrm{U}\right)+2.5$ ( $\mathrm{kg}{ }^{233} \mathrm{U}+\mathrm{kg}$ plutonium), he must, in addition to $1,2,3$ and 4 above, provide physical protection of the SNM at the facility and during transport to other facilities. In addition, in accordance with the requirements of 10 CRF Part 73 the licensee must provide similar protection to the facility itself, and to specified material access areas in the facility.

If the SNM in the facility is associated only with activities involved in waste operations (judged to include decommissioning activities), and if the

(a) "Effective kilograms of SNM" means (1) for plutonium and ${ }^{233} U$, their weight in $\mathrm{kg}$, (2) for uranium enriched to $1 \%$ and above, its weight in $\mathrm{kg}$ multiplied by the square of the enrichment (as the decimal weight fraction), and (3) for uranium enriched to less than $1 \%$, its weight in $\mathrm{kg}$ multiplied by $10^{-4}$. (10 CFR 70.22) 
quantity in the facility at any one time does not exceed five effective $\mathrm{kg}$ of plutonium, ${ }^{233} U$, or highly enriched uranium, the licensee is exempt from certain provisions of Part 70 which specify use of safe sealing procedures, material balance control 1 imits (MUF and LEMUF (a) 1imits), measurement control programs and other material control procedures (see 10 CFR Part 70, Sections 70.51(e), 70.57 and 70.58). It is likely that quantities of SNM less than 5 effective $\mathrm{kg}$ (e.g., $2 \mathrm{~kg}$ of plutonium or $233 \mathrm{U}$ ) contained in dilute form in waste materials will not be subject to safeguarding requirements beyond measurement and reporting of the quantities on hand and disposed of as waste or transferred to a waste storage facility. However, under strict interpretation of the regulations, quantities in excess of $5 \mathrm{~kg}$ in one facility would come under the more stringent physical control and protection requirements of 10 CFR Part 73 but the control would probably still be less stringent than for operating facilities with like amounts. Futhermore, it is expected that any quantity of SNM that is isolated or separated from the bulk of other radioactive or nonradioactive material will be regarded as vital and therefore safeguarded in accordance with the provisions of Parts 70 and 73 , as outlined above.

The safety and security measures that will be required for health and safety reasons, during decommissioning operations to exclude unauthorized persons from the facility, are expected to serve as an adequate safeguards measure for the sma11 and dispersed, unaccountable, quantities of SNM remaining in the facility at the initiation of decommissioning activities. Additionally, SNM control and accounting procedures for safeguards can be reasonably expected to apply only to SNM that has been removed, isolated, recovered or concentrated into a measurable and accountable form. The physical security barriers that control access of people to SNM during operations are likely to be changing during decommissioning operations. Safeguarding SNM while the normal protective barriers and methods are being modified or eliminated could become a concern. Appropriate surveillance and security measures will be needed to keep abreast of the changing nature of the facility, equipment, and structures. Safeguards procedures should be developed from the existing operational safeguards regulations to accommodate the unique security problems that are expected to be encountered during decommissioning .

(a) LEMUF - limits of error for MUF 
In summary, because of the unique nature of decommissioning activities is clear that NRC should approve a safeguards plan prior to decommissioning; this is currently assured by existing regulations in the license amendment process. The plan must cover the treatment of quantities of SNM present and identifiable in the facility and must also describe contingency plans to assure that significant accumulations of SNM in an accountable and measurable form are detected and properly handled, protected, measured and accounted for, and disposed of in a manner acceptable to the NRC.

For this study, a safeguards plan was developed to a depth sufficient for estimating cost of implementation. The basic elements of the plan are:

1) maintaining an operational level SNM program and staff until after the final chemical flushes and treatment and removal of this material from the site, then 2) reducing the facility security requirements to non-SNM status, with norma 1 industrial security to prevent public access (no special protection against sabotage). This status will be maintained until removal of the radioactive materials and a release of the site for unrestricted use. 


\section{REFERENCES}

1. Standard Review Plan for the Review of Safety Analys is Reports for Nuclear Power Plants, NUREG-75/087 (NTISUB/B/201), Office of Nuclear Reactor Regulation, U.S. Nuclear Regulatory Commission, September 1975.

2. Environmental Standard Review Plans for the Environmental Review of Construction Permit Application for Nuclear Power Plants (Draft), NUREG-0158 Parts I \& II, Office of Nuclear Reactor Regulation, U.S. Nuclear Regulatory Commission, January 1977.

3. J. J. Cohen, et a1., Determination of Performance Criteria for HighLevel Solidified Nuclear Waste, NUREG-0279, Lawrence Laboratory for USNRC, JuTy 1977.

4. C. K. Beck, "Intergovernmental Relationships in the Transport of Radioactive Materials", in Proceedings of the Second Annual Legislative Workshop, CONF-730588, Oak Ridge, TN, May 1973.

5. W. M. Rogers, Jr., "State and Federal Roles in Regulating the Transportation of Radioactive Materials", in Proceedings of the 4th International Symposium on Packaging and Transportation of Radioactive Material, CONF740901, Miami Beach, FL, September 1974.

6. W. A. Brobst, "The State of State Regulations", in Proceedings of the 4th International Symposium on Packaging and Transportation of Radioactive Material, CONF-740901, Miami Beach, FL, September 1974.

7. J. W. Healy, A Proposed Interim Standard for Plutonium in Soils, LA-5483-MS, Los Alamos Scientific Laboratory, Los Alamos, NM, January 1974.

8. A. J. Hazle and Bert L. Crist, Colorado's Plutonium-in-Soil Standard, Colorado Department of Health, Occupational and Radiological Health Division, Denver, C0, 1975. 
• 


\subsection{FACILITY AND SITE DESCRIPTION}

This section briefly describes the reference reprocessing plant for light water reactor fuels, the chemical process used in the plant and the generic site on which the plant is assumed to be located. Estimates are presented of the radioactive and chemical inventories in the facility and the maximum residual radioactive contamination levels on the site when reprocessing operations are terminated.

The Barnwell Nuclear Fuel Plant (1) (BNFP) was chosen as the reference facility for this study because it is believed to be representative of contemporary reprocessing plants in the U.S. The existing portions of the BNFP do not include facilities for high-level liquid waste solidification or for conversion of the plutonium nitrate product to plutonium dioxide. It is expected that future reprocessing plants will contain these facilities. A conceptual waste solidification plant was included in the facility description and is hypothetically decommissioned in this study. A plutonium conversion facility, the existing facilities for uranium hexafluoride conversion and for interim underground storage of solid wastes are not included in this study because they will be considered in future decommissioning studies.

Details of the plant and the plant process descriptions are presented in Appendix $A$, the site description details are given in Appendix $C$, and the bases for residual radioactivity estimates are presented in Appendix $B$ of volume 2.

\subsection{SITE DESCRIPTION}

A reference environment was developed to aid in assessing the public safety and potential environmental effects of conceptually decommissioning a FRP by various alternative methods. The meteorology parameters and population distributions used were taken from the ALAP Study ${ }^{(2)}$ for the river site in the year 2000. The ecological information was derived from the environment of one operating nuclear reactor. ${ }^{(3)}$ The remainder of the information was obtained from a variety of sources or developed specifically for this study, and is felt to be representative of potential sites for fuel cycle facilities 
in the midwestern or south mideastern United States. The details of the site are given in Volume 2, Appendix $C$ of this report.

Individual features of a specific site will vary from those of a generic site for any specified nuclear fuel cycle facility. However, it is believed that use of a generic site will result in a more meaningful overall analysis of potential impacts associated with most nuclear fuel cycle facilities. Site specific assessments will be required for the safety analysis and the Environmental Report submitted with the request for license modification prior to decommissioning the facility.

The generic site occupies 4.7 square kilometers (1160 acres) in a rectangular shape of 2 kilometers ( 1.24 miles) by 2.35 kilometers ( 1.46 miles). A moderately sized river runs through one corner of the site.

The site is located in a rural area that has relatively low population density. Higher population densities are located at distances 16 to 64 kilometers ( 10 to 40 miles) away, and gradually reducing population densities are encountered out to $177 \mathrm{kilometers} \mathrm{(110} \mathrm{miles).} \mathrm{The} \mathrm{closest} \mathrm{moderately} \mathrm{large}$ city, population 40,000 , is about 32 kilometers (20 miles) distant. The closest large city, population 1,800,000 is about 48 kilometers (30 miles) away. The total population in a radius of 80 kilometers ( 50 miles) is 3.52 million.

The plant facilities are located inside a 0.12 -square kilometer (30-acre) fenced portion of the site. The minimum distance from the point of plant airborne releases to the outer site boundary is one kilometer. In most of the surrounding area, about $80 \%$ of the land is used for farming.

The relatively clean river flowing through the site has an average flow rate of $1420 \mathrm{~m}^{3} / \mathrm{sec}$. The river is used for irrigation, fishing, boating and other aquatic recreational activities, and is a source of drinking water for the larger communities. Large supplies of flowing groundwater exist at modest depths around the site. This water is widely used for drinking and irrigation.

The reference site occupies a relatively flat terrace that has a low bluff forming one bank of the river. Biologically young soils cover the old 
basement rocks in the area. This site is in a relatively passive seismic area and is located at an elevation above the estimated maximum probable flood level.

The climate at the site is typical for internal continental areas. It has wide temperature variations and moderate precipitation. Meteorology used in this study is an average taken from 16 nuclear reactor sites, with annual average $\bar{X} / Q$ (atomospheric dispersion factor) at the closest site boundary of about $5 \times 10^{-8} \mathrm{sec} / \mathrm{m}^{3}$.(2)

Less than $20 \%$ of the 1 and around the site is covered with pristine vegetation. The original vegetation was primarily a climax deciduous forest. A number of species of migratory birds are present in the area, as well as some annual birds. A few of these are considered to be rare, endangered, or threatened by extinction. A number of mammals occupy the general area.

The site is slightly contaminated with radioactive material as a result of deposition from the release of normal operating effluents over the 30-year plant operating life. It is expected that any accidental releases of radioactive material will be cleaned up immediately following the event. Estimates of the maximum site contamination levels possible at the time of plant shutdown are shown in Table 5.1-1. The site contamination estimates are based on the predicted normal operating releases of gaseous effluents for the base case in the ORNL ALAP Study $(4)(a)$ for nuclear fuel reprocessing plants and the $\mathrm{UO}_{2}$ fuel cycle case in GESMO ${ }^{(5)}$ (normalized to a $1500 \mathrm{MT} /$ year plant). The assumptions and calculational methods for relating the normal plant effluents to site surface contamination can be found in Volume 2, Appendix $C$.

The extent to which the site is characterized here is typical of the detail required for licensing. For similar analysis of specific facilities and sites, additional depth in the environmental assessment can be pursued if judged necessary.

\footnotetext{
(a) The release rates of radionuclides in Reference 4 were divided by a factor of 10 to adjust the resulting radiation dose to the maximum exposed member of the public to be consistent with the emission requirements of 10 CFR Part 50, Appendix I for nuclear reactors.
} 
TABLE 5.1-1. Estimated Maximum Amounts of Radioactive Materials Deposited on the FRP Site Over a 30 Year Operating Lifetime

\begin{tabular}{|c|c|c|c|c|}
\hline \multirow[b]{2}{*}{ Nucl ide } & \multicolumn{4}{|c|}{$\begin{array}{c}\text { Deposited Radioactivity }\left(\mu \mathrm{Ci} / \mathrm{m}^{2}\right) \text { a } \\
\text { Selected Times After Shutdown }\end{array}$} \\
\hline & Shutdown & 10 Years & 30 Years & 100 Years \\
\hline${ }^{89} \mathrm{Sr}$ & $1.5 \mathrm{E}-5$ & $\ldots(a)$ & -- & -- \\
\hline${ }^{90} \mathrm{Sr}$ & $1.4 \mathrm{E}-3$ & $1.1 E-3$ & $6.9 E-4$ & $1.3 E-4$ \\
\hline $90_{Y}$ & $1.4 \mathrm{E}-3$ & $1.1 E-3$ & $6.9 \mathrm{E}-4$ & 1. $3 \mathrm{E}-4$ \\
\hline${ }^{91} Y$ & $2.8 \mathrm{E}-5$ & $\cdots$ & --- & --- \\
\hline${ }^{95} \mathrm{Zr}$ & $5.5 E-5$ & --- & -- & --- \\
\hline${ }^{95} \mathrm{Nb}$ & $1.1 \mathrm{E}-4$ & -- & -- & -- \\
\hline $103_{\mathrm{Ru}}$ & 4. $9 E-5$ & -- & --- & --- \\
\hline${ }^{106}{ }_{R u}$ & $2.4 \mathrm{E}-3$ & $2.6 E-6$ & 2. $9 E-12$ & -- \\
\hline $110_{\mathrm{Ag}}$ & 2. $0 \mathrm{E}-6$ & $8.8 E-11$ & $\ldots$ & -- \\
\hline${ }^{125} \mathrm{Sb}$ & $2.7 E-5$ & $2.1 E-6$ & 1. $3 \mathrm{E}-8$ & --- \\
\hline${ }^{127} \mathrm{Te}$ & $2.1 E-6$ & $1.7 E-16$ & -- & -- \\
\hline${ }^{129} \mathrm{Te}$ & $2.5 E-7$ & $\cdots$ & -- & -- \\
\hline${ }^{129} \mathrm{I}$ & $6.4 \mathrm{E}-3$ & $6.4 E-3$ & $6.4 \mathrm{E}-3$ & $6.4 E-3$ \\
\hline${ }^{131} \mathrm{I}$ & $1.6 \mathrm{E}-5$ & -- & -- & -- \\
\hline${ }^{134} \mathrm{Cs}$ & $5.5 E-4$ & 1. $9 \mathrm{E}-5$ & $2.3 E-8$ & --- \\
\hline${ }^{137} \mathrm{Cs}$ & 2. $0 E-3$ & $1.6 E-3$ & $9.9 E-4$ & $2.0 E-4$ \\
\hline${ }^{141} \mathrm{Ce}$ & $5.1 E-6$ & -- & --- & -- \\
\hline${ }^{144} \mathrm{Ce}$ & $7.4 \mathrm{E}-4$ & 9. $9 \mathrm{E}-8$ & 1. $8 \mathrm{E}-15$ & --- \\
\hline${ }^{147} 7_{\mathrm{Pm}}$ & $3.1 E-4$ & 2. $2 E-5$ & $1.1 E-7$ & $1.0 \mathrm{E}-15$ \\
\hline${ }^{154} \mathrm{Eu}$ & $6.8 \mathrm{E}-5$ & $3.0 \mathrm{E}-5$ & $6.0 \mathrm{E}-6$ & $3.1 E-8$ \\
\hline${ }^{155} \mathrm{Eu}$ & $3.7 E-5$ & 8. $7 E-6$ & $4.8 E-7$ & $1.9 \mathrm{E}-11$ \\
\hline${ }^{234} U$ & $2.0 \mathrm{E}-7$ & 2.0E-7 & $2.0 \mathrm{E}-7$ & 2. $0 \mathrm{E}-7$ \\
\hline $235 u$ & $4.4 \mathrm{E}-9$ & 4. $4 \mathrm{E}-9$ & 4. $4 \mathrm{E}-9$ & 4. $4 \mathrm{E}-9$ \\
\hline $236 u$ & $7.4 E-8$ & $7.4 E-8$ & $7.4 \mathrm{E}-8$ & $7.4 \mathrm{E}-8$ \\
\hline${ }^{238} u$ & $8.0 E-8$ & $8.0 \mathrm{E}-8$ & $8.0 \mathrm{E}-8$ & $8.0 \mathrm{E}-8$ \\
\hline${ }^{238} \mathrm{Pu}$ & $1.6 \mathrm{E}-4$ & 1. $5 \mathrm{E}-4$ & 1. $3 E-4$ & 7. $3 \mathrm{E}-5$ \\
\hline${ }^{239} \mathrm{Pu}$ & 2. $0 \mathrm{E}-5$ & 2. $0 \mathrm{E}-5$ & 2. OE -5 & 2. $0 \mathrm{E}-5$ \\
\hline${ }^{240} \mathrm{Pu}$ & $3.1 E-5$ & $3.1 E-5$ & $3.1 E-5$ & $3.0 E-5$ \\
\hline${ }^{241} \mathrm{Pu}$ & 2. $7 E-3$ & 1. $3 \mathrm{E}-3$ & $3.0 \mathrm{E}-4$ & $1.9 \mathrm{E}-6$ \\
\hline${ }^{242} \mathrm{Pu}$ & $8.6 \mathrm{E}-8$ & $8.6 \mathrm{E}-8$ & $8.6 E-8$ & $8.6 \mathrm{E}-8$ \\
\hline${ }^{241} \mathrm{Am}$ & $1.0 E-4$ & $1.5 E-4$ & $1.9 E-4$ & 1. $9 E-4$ \\
\hline${ }^{243} \mathrm{Am}$ & $4.6 \mathrm{E}-7$ & 4. $6 \mathrm{E}-7$ & $4.6 \mathrm{E}-7$ & $4.6 \mathrm{E}-7$ \\
\hline${ }^{242} \mathrm{~cm}$ & $9.4 \mathrm{E}-6$ & 1.7E-12 & -- & -- \\
\hline${ }^{244} \mathrm{~cm}$ & $3.6 E-5$ & $2.4 \mathrm{E}-5$ & $1.1 E-5$ & $7.4 \mathrm{E}-7$ \\
\hline
\end{tabular}

(a) Dash indicates deposition is less than $10^{-15} \mu \mathrm{Ci} / \mathrm{m}^{2}$. 


\subsection{PROCESS DESCRIPTION}

Overall processing characteristics assumed for the reference plant are presented in Table 5.2-1. The plant uses the Purex Process to recover plutonium and uranium from irradiated LWR fuels. A simplified block flow diagram of the process is shown in Figure 5.2-1.

The irradiated fuel is received in heavily shielded casks and is unloaded and stored underwater in the Fuel Receiving and Storage Station (FRSS). When ready for processing, each fuel assembly is transferred under water to the main process building. Here the fuel assemblies are partly disassembled, chopped into pieces up to $10 \mathrm{~cm}$ long and dropped into a dissolver vesse 1 where the fuel materials are dissolved with nitric acid. Volatile fission products (i.e., noble gases, tritium, halogens and carbon) are released to the effluent cleanup system during this processing step. The fuel cladding hulls are packaged and taken to a bunker-type interim storage area onsite.

The fuel materials, which are now in an aqueous solution with nitric acid, are centrifuged and sent to the first stage of solvent extraction. Here the uranium and plutonium are extracted into the organic phase in a centrifugal contactor while most of the other transuranium elements and fission products remain in the aqueous nitrate solution. The latter solution, called high-level liquid waste (HLLW), also contains about $0.5 \%$ of the unrecovered uranium and plutonium. After concentration, the high-level waste is transferred to underground tanks for interim storage.

The organic stream containing the uranium and plutonium is scrubbed in a pulse column contactor to remove additional fission products and transuranium elements. The solution is then processed through an electro-pulse column contactor where the chemical valence of the plutonium is reduced to an "inextractable" state, and the plutonium is extracted into an aqueous stream.

The plutonium stream is processed through two additional stages of solvent extraction to remove residual fission products and other impurities. The product plutonium nitrate solution is concentrated and temporarily stored before being converted to plutonium dioxide for offsite shipment. 


\section{TABLE 5.2-1. Overal1 Processing Characteristics of the Reference Plant}

FEED Fuels from Light Water Reactors (Zircaloy or stainless steel cladding)

- $\mathrm{UO}_{2}$ (Up to $3.5 \%$ enrichment when charged to reactor)

- $\mathrm{UO}_{2}-\mathrm{PuO}_{2}$ ( $\mathrm{Pu}$ up to equivalent of $3.5 \%{ }^{235} \mathrm{U}$ when charged to reactor)

- Special fuels up to $5 \%$ initial enrichment under special operating conditions

Fuel Burnup (a)

- Average PWR exposure of 31,800 MWD/MTHM (peak of 33,000 MWD/MTHM)

- Average BWR exposure of 25,300 MWD/MTHM (peak of 26,000 MWD/MTHM)

- Average total exposure of 29,300 MWD/MTHM

Fuel Out-of-Reactor Time

- Minimum 90 days upon receipt

- Minimum 1.5 years before reprocessing $(a)$

CAPACITY 1500 MT/yr (30-yr lifetime ${ }^{(a)}$ )

5 MT/day instantaneous

PRODUCTS Uranyl nitrate solution (fed to the onsite UF ${ }_{6}$ conversion facility) Plutonium nitrate solution (fed to onsite $\mathrm{PuO}_{2}$ conversion facility(a))

WASTES High-Level and intermediate-level wastes interim stored as liquids in underground tanks

High and intermediate level liquid wastes converted within 5 years to a vitrified solid and shipped offsite to a federal repository. $(\bar{a})$

Fuel cladding hulls, failed equipment and other solid wastes interim stored onsite in concrete or stainless steel containers in engineered underground storage prior to shipment offsite for disposal.

EFFLUENTS Gases (only routine radioactive effluents)

- $\mathrm{Kr}-85$ discharged up main stack (100 meters ta17)

- Most tritium, carbon-14 discharged to main stack

- Excess water discharged up main stack

Heat rejected to cooling tower via closed loop heat exchangers

Uncontaminated process liquid wastes diluted and discharged to river.

(a) Processing characteristics listed are different from those postulated for near-term operation of BNFP. The information presented is currently expected to be representative of long-term operating characteristics at a plant such as BNFP. 


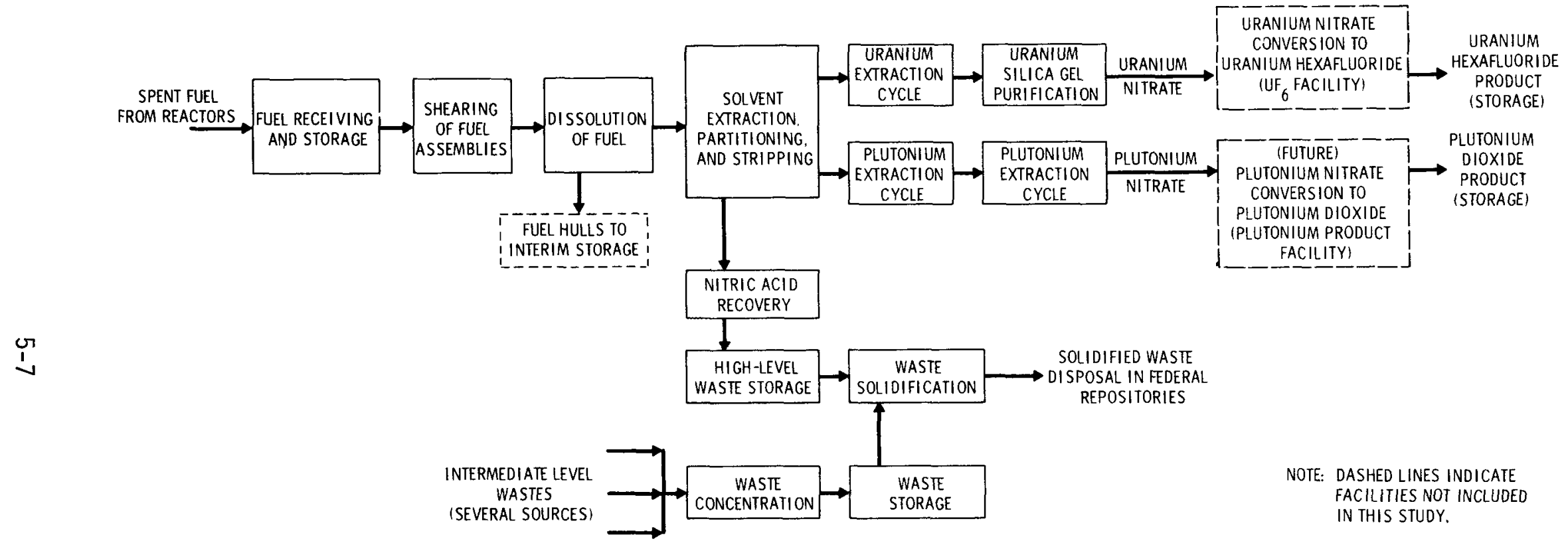

FIGURE 5.2-1. Simplified Process Flow Diagram for Reference Fuel Reprocessing Plant 
The uranium solution is processed through a solvent extraction cycle followe by silica gel for final cleanup before being transferred to the nearby $\mathrm{UF}_{6}$ conversion facility. (a)

A variety of auxiliary processing activities is carried out in support of the main process outlined above. The auxiliary processing activities include liquid waste treatment, organic solvent treatment, process off-gas treatment, nitric acid recovery, and solid waste treatment and storage. Each of these auxiliary processes is described briefly below.

- Liquid Waste Storage and Treatment

Radioactive liquid wastes are concentrated for volume reduction, stored temporarily in underground tanks and solidified onsite for offsite disposal. Radioactive liquid wastes are classified as high-level (HLLW), or intermediate-level (ILLW). Separate facilities are provided for concentrating and storing these wastes. The HLLW stream contains most of the fission products and trans-plutonium actinides orginally present in the spent fuel. Storage tanks for the HLLW are equipped to remove the radioactive decay heat from the waste and to constantly mix and vigorously agitate the solution using air-operated devices. All nonhigh-level radioactive liquid wastes are combined to form the ILLW stream. Since radioactivity levels in the ILLW are several orders of magnitude lower than the HLLW, no cooling is necessary and only mild agitation is used in the ILLW storage tank.

After a storage period of one to two years, the intermediate- and highlevel liquid waste streams are combined for solidification in the waste solidification plant adjacent to the main process building. The spray calciner plus in-can-melter process presently under development at Battelle, Pacific Northwest Laboratories ${ }^{(6)}$ has been selected as representative of a process that can be used to solidify liquid wastes from a commercial reprocessing facility. In this process, wastes from the HLLW and ILLW storage tanks are combined in a feed tank and converted to a dry powdered oxide (calcine) in a spray calciner. The calcine is combined with ground borosilicate

(a) The $\mathrm{UF}_{6}$ facility and a future $\mathrm{PuO}_{2}$ conversion facility have not been decommissioned in this study. These types of facilities will be considered in future decommissioning studies. 
lass (frit) in a stainless steel canister that is heated until the frit and calcine form a molten glass. The full canister of glass is cooled to solidify the molten glass, sealed, decontaminated and transferred to the fuel receiving and storage station for storage and eventual offsite shipment. (a)

- Organic Solvent Treatment

Used organic solvent streams are washed in two or three contactors to remove organic degradation products. The solvents are then recycled for reuse and the degradation products are burned. The aqueous wash waste streams from the organic treatment are sent to a waste evaporator and stored with the intermediate-level liquid waste.

- Off-gas Treatment

Off gases from the fuel shearing and dissoiving operations are scrubbed to remove radioactive iodine and aerosols, then treated in a absorber to remove nitric acid. These treated gases are combined with other process vessel off-gas streams and passed through a second iodine scrubber, packed iodine adsorber beds and high efficiency filters before final release to the stack. Off gases from the waste solidification process are treated in a separate off-gas treatment system and combined with the vessel off-gas stream before the final stage of high efficiency air filters. Recovered nitric acid is fractionated to a concentrated form and reused. The excess water from the nitric acid fractionation process is vaporized to the main stack.

- Solid Waste Processing

Solid radioactive waste processing involves the separate packaging of cladding hulls, failed equipment, and miscellaneous trash. These wastes are stored temporarily onsite in an underground bunker before shipment to an approved offsite disposal facility.

\subsection{PLANT DESCRIPTION}

The main facilities of the reference reprocessing plant are shown in a photograph of the Barnwell Nuclear Fuels Plant presented in Figure 5.3-1.

(a) A full canister of mixed high- and intermediate-level waste is generally referred to as a canister of solidified high-level waste in this study. 


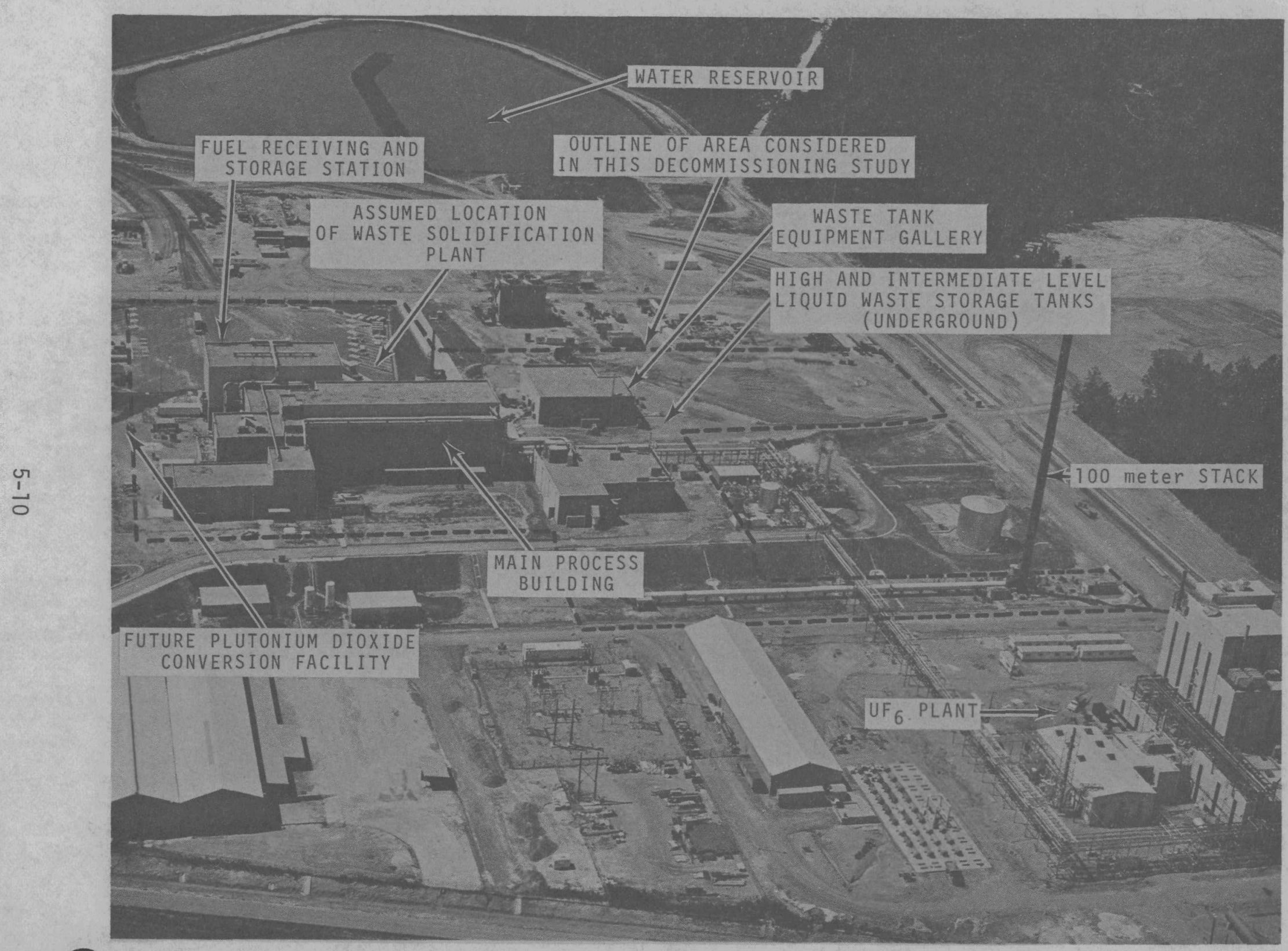

FIGURE 5.3-1. Photograph of Barnwell Nuclear Fuel Plant 
The fence shown in the figure surrounds the security-protected area. The facilities included in this study are inside the area designated by a dashed line on the figure. The major facilities included in this study are: 1) the fuel receiving and storage station; 2) the main process building; 3) the highand intermediate-level liquid waste storage area; 4) the waste solidification plant; and 5) the radioactive auxiliary service areas. A brief description of each of these facilities is given in the remainder of this section. Detailed descriptions of these facilities are presented in Volume 2, Appendix A.

\subsubsection{General Plant Design Bases}

The reference reprocessing plant was designed and constructed to minimize release of radioactive materials both during routine operation and under accident conditions. At least two physical barriers (frequently more than two) contain the radioactive materials within the facility during operation. These barriers are typically the process equipment (vessels, pipes, etc.) and the building around the process equipment. In most cases, the building itself provides two barriers: the hot cell or room where the process equipment is located, and the outer building shell.

The only routine releases of radionuclides are through the airborne pathway. The process equipment is connected to the airborne pathway through a series of gas or vapor process treatment steps designed to remove radioactive materials from the air before it exits via the stacks.

Process equipment is fabricated from materials that are resistant to failure from corrosion. Where failure of process equipment under conditions assumed to be credible can result in major releases of radionuclides, the equipment design basis is designated "Q". (a) "Q" systems must provide containment integrity during a design basis earthquake or a design basis storm such as a tornado. In other less critical areas the design membrane stress of the equipment is 80 to $90 \%$ of yield stress during a design basis earthquake.

\footnotetext{
(a) A "Q" classification identifies systems whose failure could cause an immediate potential hazard to the public. An immediate potential hazard exists whenever insufficient time or accessibility would be available to take corrective action to prevent an unacceptable offsite release.
} 
Structural barriers are designed to contain process materials if prim equipment barriers are breached. The principal structural barriers are constructed of heavily reinforced concrete. They are partially lined with stainless steel in those areas containing radiologically hazardous materials to make decontamination easier.

The process structural barriers are generally termed radioactive process cells, and are typically surrounded by maintenance or operating areas. The process cell where the spent fuel is chopped and dissolved and high-level liquid wastes are concentrated contains very high radiation levels. This cell is designed for remote maintenance (i.e., maintenance from outside the cell through the use of in-cell cranes, or shielding windows and manipulators). Similarly, a cell for remote packaging of radioactive wastes and for performing remote decontamination and maintenance on equipment removed from other process cells is also provided. The remaining process cells are designed for direct personnel entry and contact maintenance, but only after appropriate remote decontamination has been completed to allow safe entry.

\subsubsection{Fuel Receiving and Storage Station}

The fuel receiving and storage station (FRSS) is designed to receive and store irradiated fuel elements from light-water power reactors. The spent fuel assemblies are received in shielding casks by either truck or rail, and unloaded under water. The fuel elements are stored under water to provide cooling and shielding. For this study the FRSS is also assumed to be used for temporary underwater storage and loadout of canisters of solidified high-level waste. Facilities for decontaminating the shipping casks before they leave the plant are also provided, in addition to equipment to circulate, filter, deionize and cool the storage pool water. The major areas of the FRSS are shown in Figure 5.3-2 and their primary functions are listed in Table 5.3-1.

The FRSS is connected to the main process building by the fuel transfer conveyor tunnel and to the conceptual waste solidification plant by an underwater transfer aisle. The pool walls and liners are designed to maintain their containment integrity in a design basis earthquake or tornado. Building walls above the pools are non-"Q" structures. 
TABLE 5.3-1. Primary Function of Areas in Fuel Receiving and Storage Station

Area

Vehicle UnToading Bays (2)

Test and Decontamination Pit

Cask Unloading Pools (2) (CUP)

Decontamination Pit

Fuel Storage Pool

Fuel Transfer Pool

Deionization Area
Process Functions

Receive Rail and Truck Casks;

Unload Casks From Transport

Vehicle;

Load Casks on Transport

Vehicle

Prepare Casks for Unloading SS Liner in CUP

Remove Fuel From Casks;

Place Solidified Waste

Canisters in Casks

Decontaminate Casks after

Removal from CUP

Store Fuel Assemblies and

Solidified Waste Canisters

Transfer Fuel Assemblies

to Main Process Building

Circulate, Filter, Deionize

Pool Water
Remarks

SS Liner

SS Liner

SS Liner; Aluminum Storage Racks

SS Liner

\subsubsection{Main Process Building}

The main process building is the functional center of the reference reprocessing plant. The uranium and plutonium are chemically separated from the spent fuel in this building. This processing is carried out in a series of main process cells that occupy a major portion of the building. The main process building also contains a wide variety of facilities and equipment that are used to monitor and control the process, maintain the equipment, carry out auxiliary operations and treat gaseous effluents from the processes carried out in the building.

The major features of the main process building are shown in Figures 5.3-2 and 5.3-3. The primary functions of the main process cells are listed in Table 5.3-2. Most of the building is constructed of reinforced concrete designed to remain intact in a design basis earthquake or tornado. Process cell walls are up to $2 \mathrm{~m}$ thick to provide personnel shielding from radioactivity. 


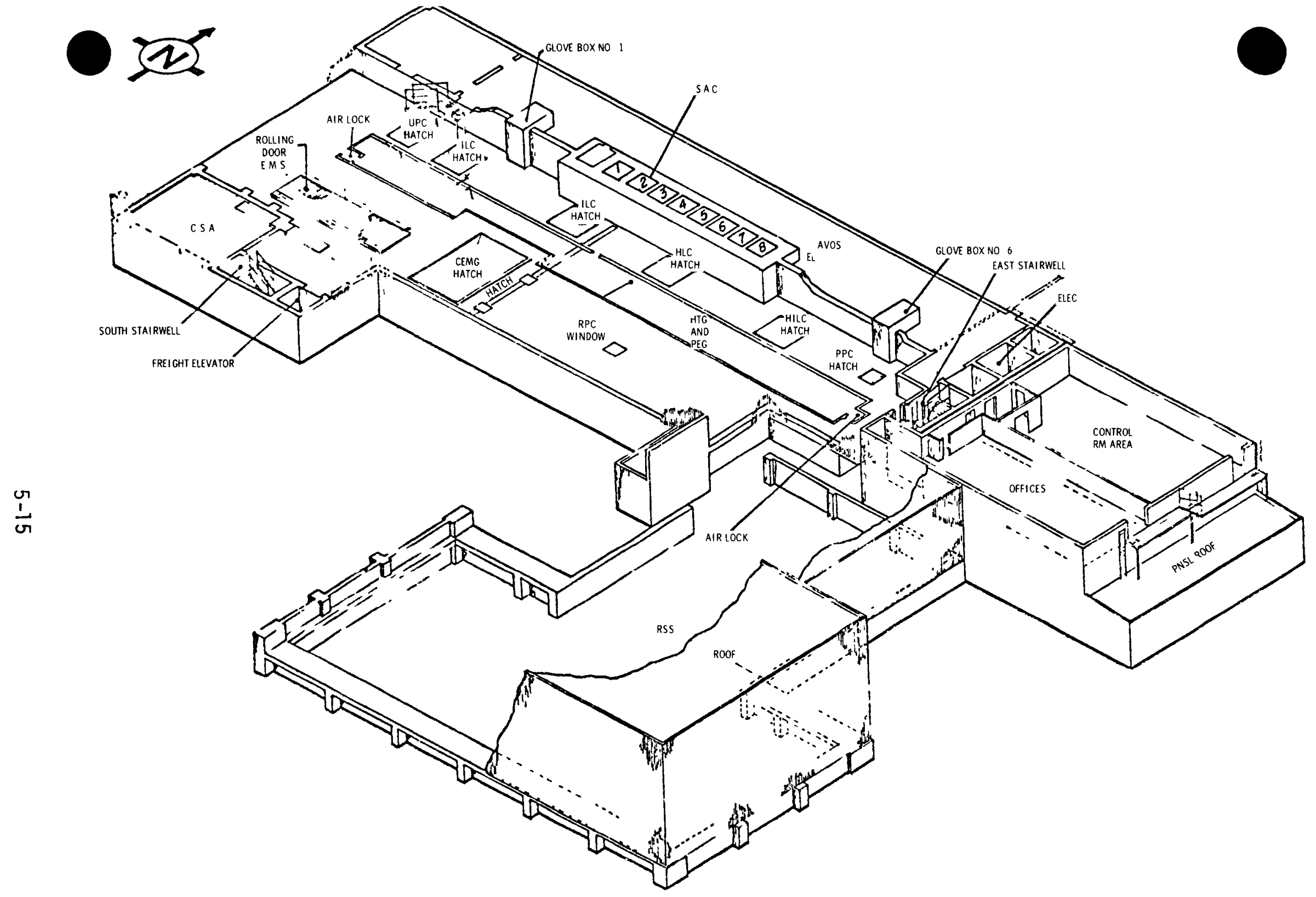

FIGURE 5.3-3. Main Process and Fuel Receiving and Storage Station Building, Upper Elevations 
TABLE 5.3-2. Primary Functions of Main Process Cells

Cell

Remote Process Cell

(RPC)

Remote Maintenance and Scrap Cell (RMSC)

High Lever Cel1 (HLC)
Primary Process Functions

Shear and Dissolve Fuel;

Concentrate HLLW

Package Leached Hulls and

Other Solid Waste;

Remotely Maintain Contaminated Equipment

Accountability for Dissolver Solution;

Chemically Adjust Dissolver Solution;

Centrifuge Dissolver

Solution

High-Intermediate Level Ce11 (HILC)

Intermediate Level Cell (ILC)

Uranium Product Cell (UPC)

Plutonium Product Cell (PPC)

Plutonium Nitrate Storage and Loadout (PNSL)
Separate $U$ and $P u$ from

High-Level Waste;

Separate U from Pu;

Treat Dissolver Off-Gas;

Solvent Cleanup;

Concentrate IntermediateLevel Waste

Treat Vessel Off-Gas;

Recover Nitric Acid;

Concentrate Low-Level

Waste;

Burn Used Solvent;

Purify Uranium Stream;

Clean up Solvent

Purify Plutonium Stream

Store Plutonium Nitrate Solutions;

Transfer Plutonium Nitrate to Plutonium 0xide Conversion Facility
Remarks

Remote Maintenance;

SS Floor Plan

SS Walls and Floor

SS Floor Pan;

Contact Maintenance

SS Floor Pan;

Contact Maintenance

SS Floor Pan;

Contact Maintenance

SS Floor Pan;

Contact Maintenance

SS Floor Pan;

Contact Maintenance

SS Floor Pan;

Contact Maintenance 
The areas outside of the main process cells are generally divided into regions called "galleries" or "stations". These areas enclose and protect service piping, process support equipment, instrumentation components, and some operating areas. Radioactivity levels in these areas range from essentially background to modest levels.

Other features of the main process building that are of interest for this study are discussed briefly below.

- Control Room Area (CRA)

The central control room houses the process control and safety-related instrumentation for the plant. It serves as the communications center from which operators can be directed to perform manual functions. The control room area is not expected to be contaminated, since the only process connections to other facility areas are electrical.

- Sample and Analytical Cells (SAC)

The SAC is a shielded facility designed to provide radiochemical analyses for samples from the more highly radioactive portions of the process. The cells provide a shielded area for remote sampling and analysis of these materials and for preparation of samples to be analyzed in the plant laboratories. Operation is through shielding windows and manipulators, and glove boxes.

- Decontamination Facilities

A central mixing and distribution system for decontamination solutions is provided for contact maintenance cells. The system is composed of mixing tanks, heating coils, and pumps. Decontamination solutions can be introduced directly into the process equipment through temporary connections or into the process cells through installed spray nozzles.

- Filter Niche (FN)

The filter niche houses roughing and HEPA filters for the RPC and RMSC ventilation exhaust, prefilters for process vessel off-gas iodine adsorbers, and the silver zeolite iodine adsorbers. It consists of two long, low, stainless steel-lined vaults joining to form an L-shaped room. 


\subsubsection{Liquid Waste Storage Areas}

High- and intermediate-level liquid wastes from the reprocessing operations are concentrated and stored in large underground tanks until they are treated in the waste solidification plant and shipped offsite for disposal. The liquid waste storage complex is composed of three high-level liquid waste (HLLW) tanks, one intermediate-level liquid waste (ILLW) tank and a waste tank equipment gallery (WTEG) that provides services for the tanks. One HLLW tank remains empty at all times as a spare for use if difficulties arise with any tank of HLLW or ILLW.

The WTEG is a concrete building approximately $30 \mathrm{~m}(100 \mathrm{ft})$ square located near the main process building (Figure 5.3-1). It houses the control room, heat exchangers, coolant circulating pumps, off-gas treatment equipment and ventilation filters for the waste storage tanks. These tanks are connected through a small diverter cell beneath the WTEG and through underground pipe vaults to the main process building and the waste solidification plant.

A11 four tanks are constructed of stainless steel. The tanks are $16.5 \mathrm{~m}$ in diameter by $6.1 \mathrm{~m}$ high and have a working capacity of 1,135,000 liters. Each tank is contained within its own underground concrete vault. The vaults (covered with about $3.7 \mathrm{~m}$ of earth) are about $18.3 \mathrm{~m}$ in diameter and $8 \mathrm{~m}$ high and are lined with stainless steel. The tanks are supported off the floors of the vaults by stainless steel strips $1.3 \mathrm{~cm}$ thick by $2.5 \mathrm{~cm}$ wide. The vault is sloped slightly from one side to the other and a flushing pipe header is installed on the high side of the vault floor. The stainless steel strips supporting the tanks are arranged to channel the flush solution from the header under the tank to the vault sump.

The high- and intermediate-level liquid waste tanks differ mainly in their internals. The HLLW tanks contain a densely packed array of forty-eight 5-cm diameter cooling coils to remove the decay heat from the waste solution and a system of air-operated ballast tanks and air lift circulators that constantly and vigorously mix the solution in the tank to prevent accumulation of waste solids on the tank bottom. The tanks also contain multiple external temperature sensing points and are provided with 10 instrument dip tubes. An overall view of an HLLW tank is shown in Figure 5.3-4. 


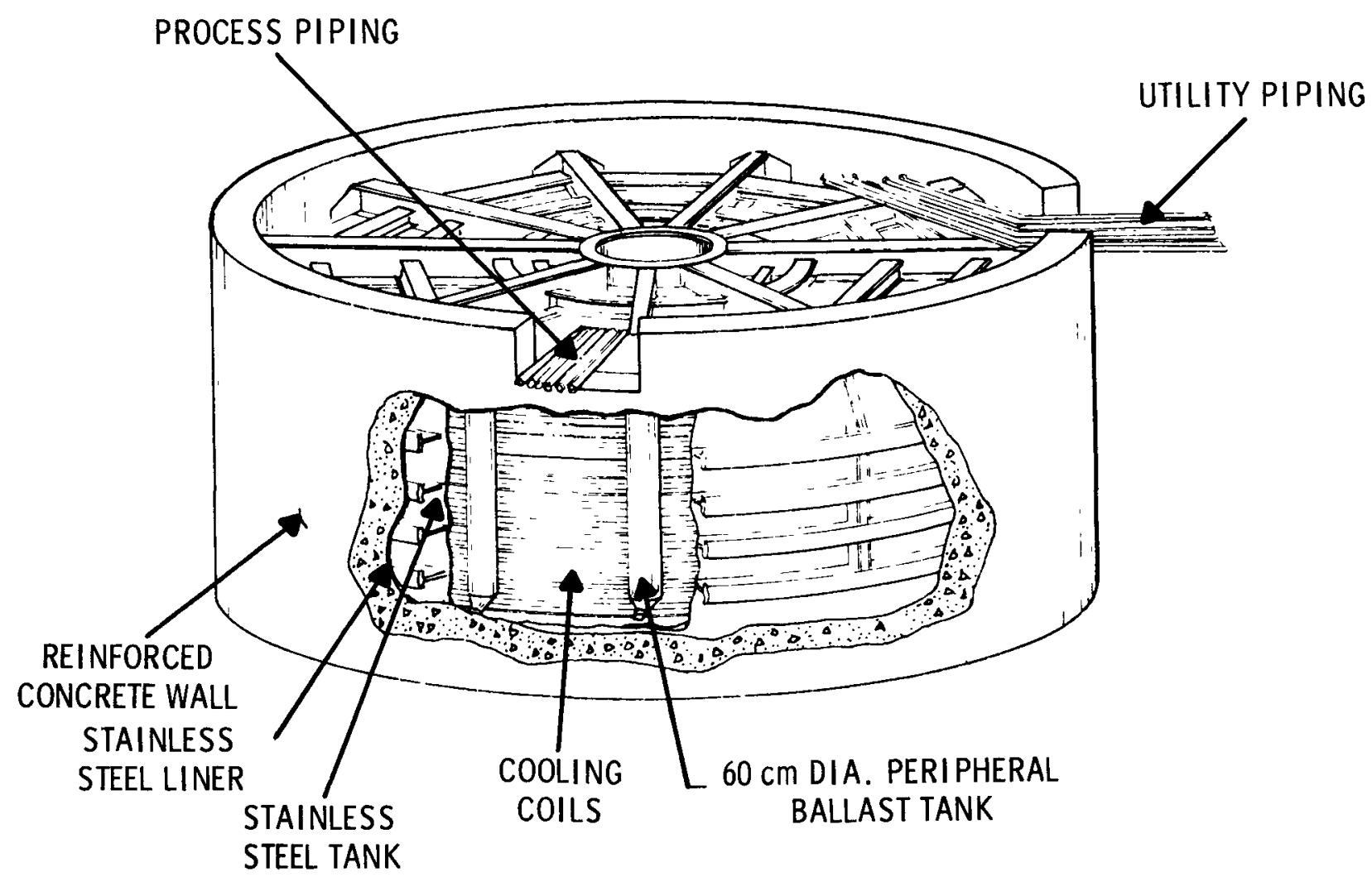

FIGURE 5.3-4. HLLW Storage Tank

The ILLW tank has no cooling coils and is provided with fewer temperature sensing points than the HLLW tanks. It has a system of air spargers (rather than air lift circulators and ballast tanks in the HLLW tanks) to mix the solution in the tank. The ILLW tank is provided with a large diameter riser that permits installation of a long shaft pump to remove residual solution from the tank.

\subsubsection{Waste Solidification Plant}

The waste solidification plant (WSP) is postulated to be located adjacent to the main process building (see Figure 5.3-1). It receives liquid waste solutions from the waste tank farm complex, converts the liquids to a vitrified solid and transfers the solidified high-level wastes to the FRSS for storage and eventual shipment offsite. 
A drawing of the conceptual waste solidification plant is presented in Figure 5.3-5. The WSP contains the waste vitrification equipment, canister sealing, inspection and decontamination equipment, off-gas treatment equipment and remote maintenance facilities in four process cells. The primary process functions performed in each of the cells are presented in Table 5.3-3. All process cells in the WSP are completely lined with stainless steel. The cells are surrounded by areas for operating and controlling the processes in the cells. All operation and maintenance activities in the process cells are performed remotely using viewing windows, manipulators and cranes.

TABLE 5.3-3. Primary Functions of Major Waste Solidification Plant Process Cells

\begin{tabular}{|c|c|}
\hline Area & Function \\
\hline Waste Vitrification Cell & $\begin{array}{l}\text { Calcine Liquid Waste; } \\
\text { Vitrify Calcined Waste; } \\
\text { Weld Canisters Closed }\end{array}$ \\
\hline \multirow[t]{2}{*}{ Canister Decontamination Cell } & $\begin{array}{l}\text { Decontaminate luter Sur- } \\
\text { faces of Canisters; }\end{array}$ \\
\hline & $\begin{array}{l}\text { Transfer Filled Cansiters } \\
\text { to FRSS }\end{array}$ \\
\hline Off-Gas Treatment Cell & $\begin{array}{l}\text { Treat Off Gas from WSP } \\
\text { Process Vessels }\end{array}$ \\
\hline Hot Maintenance Cell & $\begin{array}{l}\text { Perform Remote Maintenance } \\
\text { on Contaminated Equipment }\end{array}$ \\
\hline
\end{tabular}

It is postulated that there may be one tank ful 1 of HLLW and $1 / 2$ tank full of ILLW in the tank farm when reprocessing operations at the facility are terminated. The WSP will thus remain in operation for about 1.3 years following plant shutdown to solidify this inventory of high- and intermediatelevel liquid wastes and the waste solutions generated from final operational cleanout flushes. As part of decommissioning, the WSP will require an additional 0.8 year to process the flushes carried out during the decommissioning operations. 


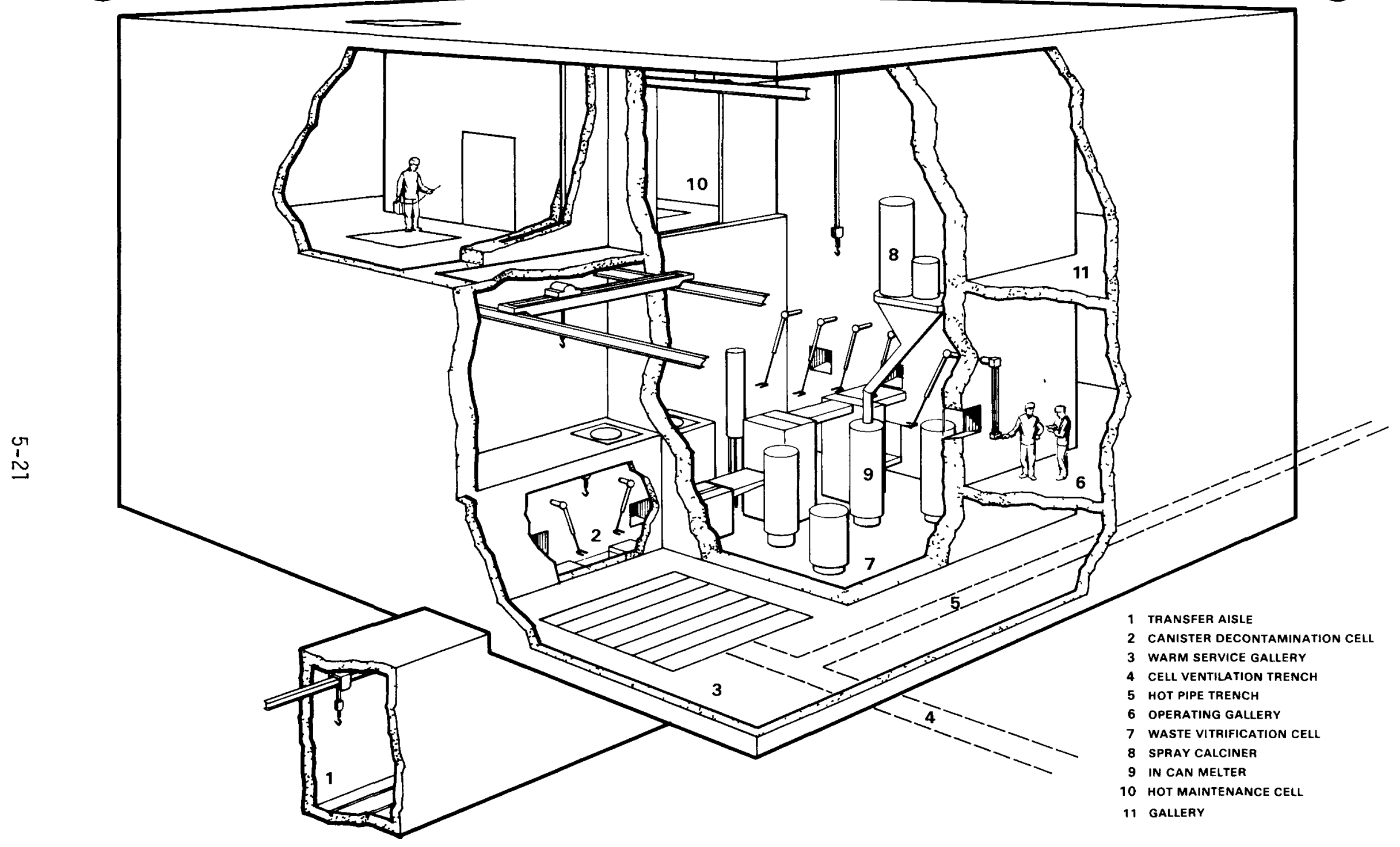

FIGURE 5.3-5. Conceptual Waste Solidification Plant 


\subsubsection{Auxiliary Process Systems and Service Areas}

The auxiliary process systems and service areas provide necessary services to the main process functions of the facility. The major areas of interest in this study are described briefly below.

- Ventilation System

The ventilation system consists primarily of supply and exhaust subsystems. The ventilation system is designed to provide once-through air flow by pressure controls from noncontaminated areas through potentially contaminated or low contaminated areas to contaminated areas (i.e., process cells), then to treatment systems before being pumped by blowers out the stack. Three blowers provide exhaust forces for the main ventilation system. Each blower is capable of supplying $50 \%$ of required capacity. All three blowers are connected to emergency power sources. A schematic diagram of the reprocessing plant ventilation system is presented in Figure 5.3-6.

Exhaust gases from the radioactive processing cells pass through at least two stages of high efficiency particulate air (HEPA) filters. Off gases from areas with high plutonium concentrations pass through three stages of HEPA filters. These extra stages of filtration are designed to provide for a minimum of one stage of filtration in event of failure of the upstream filters by mechanisms such as fire. Exhaust gases from the main process and building ventilation systems exit through the main stack (100 m high). Noncondensible gases from the service concentrator overheads vent through the service concentrator stack ( $30.5 \mathrm{~m}$ high). Chemical makeup and addition tanks vent through the chemical off-gas stack (29 $\mathrm{m}$ high).

A major feature of the ventilation system is the ventilation filter station (VFS). It houses the primary supply and exhaust blowers and the final stage of HEPA filters through which exhaust air passes before it exits through the $100 \mathrm{~m}$ stack. The VFS is located near the main process building (see Figure 5.3-1).

\section{- Electrical Power}

Normal electrical power is provided to the facility from a commercial substation by two transformers, each feeding a 2000-ampere main breaker. The main breakers distribute power through twelve 120-ampere feeder breakers. 


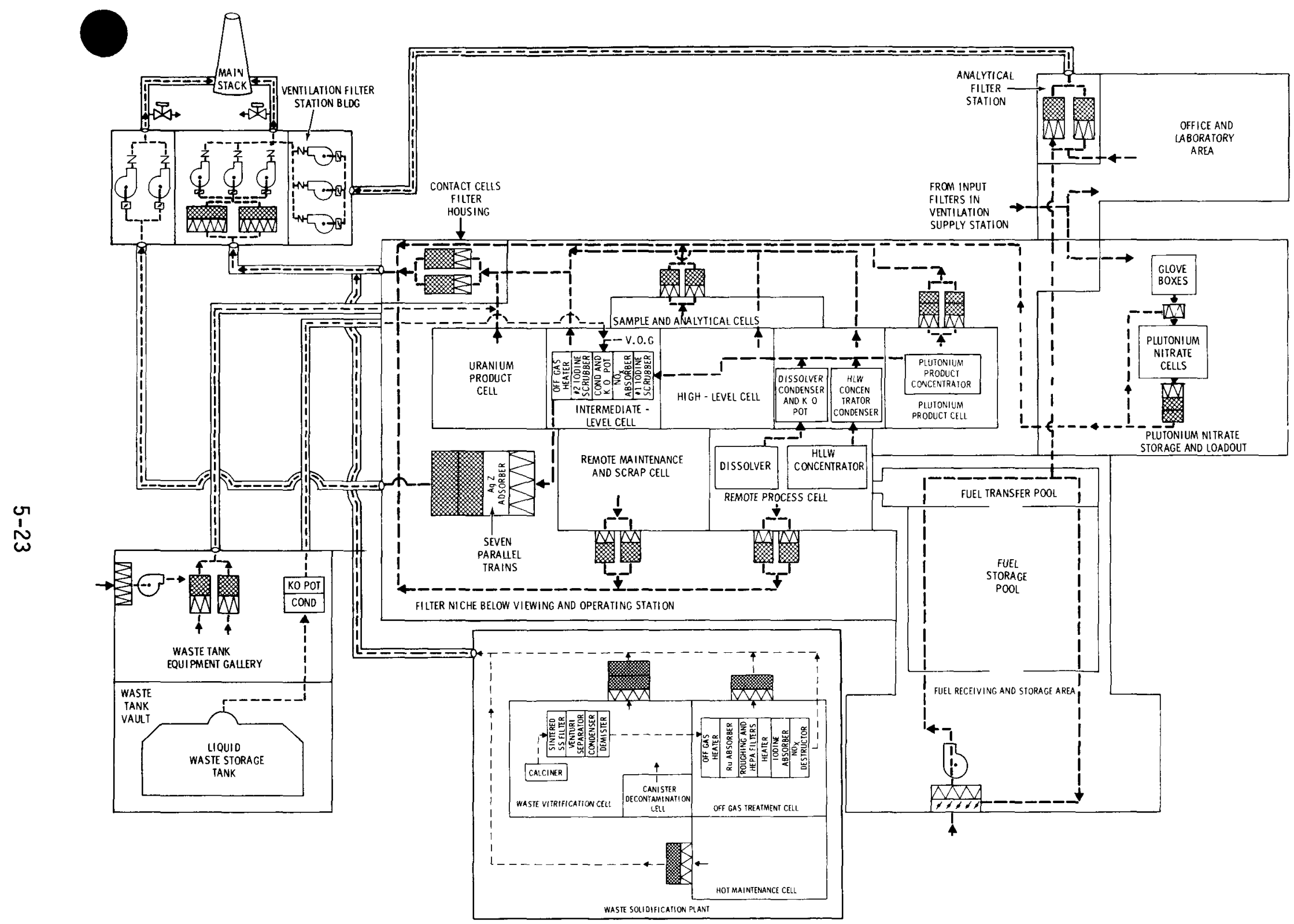

FIGURE 5.3-6. Ventilation System Schematic for Process Areas of Reference Fuel Reprocessing Plant 
The emergency electric power system is designed to handle essential electrical loads in emergency situations. Emergency power is supplied by two independent diesel engine-driven generators. Each generator has a 2200-kW continuous rating. An emergency battery power supply is provided for instrumentation in the main control room, waste tank equipment gallery area and the waste solidification plant.

- Fire Protection System

Fire detection and protection systems at the facility are designed to provide early detection and rapid control of fire. The facility has automatic fire detection devices and audible alarms in all areas. The process cells have dual detection systems. The remotely maintained process cells use manually operated Halon 1301 and water spray mist systems. The contact maintained cells have an automatically operated Halon 1301 system. The filter stations have automatic water mist suppression systems, and the FRSS has manually operated fire hoses. Most other areas use a manually operated water sprinkler system.

- Hot and Cold Laboratory Area (HCLA)

The laboratories provide analytical services for all nonradioactive and most radioactive process samples. The two-story laboratory complex is at the upper levels of the main process building, and is composed of 13 individual laboratories equipped to provide specific types of analyses or services. One of the laboratories is equipped for receiving samples from the SAC. Some of the laboratories are operated through thick shielding windows using manipulators. Others are used by working in glove boxes or hoods.

\subsection{RESIDUAL RADIOACTIVITY ESTIMATES}

This section presents an estimate of radioactivity levels in the reference reprocessing plant after reprocessing operations have been terminated and final operational cleanout flushes of the process areas have been completed. These estimates are summarized in Table 5.4-1. Decommissioning operations in most portions of the facility typically begin with a thorough chemical decontamination (see Section 7.2). Estimates of the radioactivity levels remaining after this chemical decontamination are also presented in the table. 


\begin{tabular}{|c|c|c|c|c|c|c|}
\hline \multirow{2}{*}{ Area (1) } & \multicolumn{3}{|c|}{ At Time of Shutdown $(a)(b)$} & \multicolumn{3}{|c|}{ After Chemical Decontamination $(c)$} \\
\hline & $\begin{array}{c}\text { Radioactivity } \\
\left(\mathrm{C}_{1}\right)\end{array}$ & $\begin{array}{c}\text { Dose Rate } \\
\text { Background } \\
\end{array}$ & Rot Spots & $\begin{array}{l}\text { Radioactivity } \\
\text { (C1) }\end{array}$ & $\begin{array}{l}\text { Dose Rate } \\
\text { Background } \\
\end{array}$ & $\frac{m R / h r)}{\text { Hot Spots }}$ \\
\hline \multicolumn{7}{|l|}{ FRSS } \\
\hline Pools $(d)$ & $<5$ & $<0 \quad 1-10$ & $-\cdots$ & $<5$ & $1-10$ & 100 \\
\hline Deionization Area & $<100$ & $10-100$ & 1,000 & $<100$ & $10-100$ & 1,000 \\
\hline \multicolumn{7}{|l|}{ Main Process Burlding } \\
\hline UPC & 200 & $20-200$ & 2,000 & 50 & $10-100$ & 1,000 \\
\hline ILC & 200 & $20 \div 200$ & 2,000 & 50 & $10-100$ & 1,000 \\
\hline HLC & 8,000 & $2,000-20,000$ & 100,000 & 400 & $70-700$ & 10,000 \\
\hline HILC & 1,500 & $300-3,000$ & 30,000 & 60 & $10-100$ & 10,000 \\
\hline$R P C$ & 130,000 & $20,000-200,000$ & $7 \times 10^{6}$ & 5,500 & $800-8,000$ & 100,000 \\
\hline RMSC & 1,500 & $300-3,000$ & 30,000 & 30 & $5-50$ & 500 \\
\hline PPC & 5,000 & $1,000-10,000$ & 100,000 & 1,100 & $80-800$ & 10,000 \\
\hline PNSL $(e)$ & 600 & $100-1,000$ & 10,000 & 120 & $30-300$ & 3,000 \\
\hline SAC & 100 & $20-200$ & 2,000 & 10 & $5-50$ & 500 \\
\hline Filter Niche ${ }^{(f)}$ & 200 & $30-300$ & 5,000 & $<60$ & $1-10$ & 50 \\
\hline Galleries (Typical) & $<2$ & $1-10$ & 50 & $<1$ & $05-5$ & 10 \\
\hline Stations (Typical) & $<1$ & $05-5$ & 20 & $<1$ & $01-1$ & 10 \\
\hline \multicolumn{7}{|l|}{ Liquid Waste Storage } \\
\hline WTEG-Hot Areas & $<1,000$ & $200-2,000$ & 20,000 & 300 & $70-700$ & 7,000 \\
\hline -Intermediate Areas & $<100$ & $20-200$ & 2,000 & 30 & $10-100$ & 1,000 \\
\hline -Cold Areas &.-- & $<0\}$ & $<0 \quad 1$ & -- & $<01$ & $<01$ \\
\hline$-W T D C$ & 5,000 & $10,000-100,000$ & $10^{6}$ & 30 & $10-100$ & 1,000 \\
\hline HLLW Tanks (each) & $1 \times 10^{7}$ & $10^{6}-10^{7}$ & $10^{8}$ & 3,000 & $1,000-10,000$ & 50,000 \\
\hline ILLW Tanks & $1 \times 10^{4}$ & $1,000-10,000$ & 100,000 & 10 & $100-1,000$ & 10,000 \\
\hline \multicolumn{7}{|l|}{ Waste Solidification Plant } \\
\hline WVC & 10,000 & $10,000-100,000$ & $10^{6}$ & 4,500 & $1,000-5,000$ & 50,000 \\
\hline HMC & 10 & $10-100$ & 500 & $<1$ & $05-5$ & 10 \\
\hline $\operatorname{CDC}$ & 50 & $10-100$ & 1,000 & 50 & $10-100$ & 1,000 \\
\hline OGTC & 500 & $100-1,000$ & 10,000 & 5 & $1-10$ & 100 \\
\hline Operations Areas (Typical) & $<1$ & $05-5$ & 10 & $<1$ & $01-1$ & 10 \\
\hline HPT & 500 & $300-3,000$ & 30,000 & 3 & $1-10$ & 100 \\
\hline \multicolumn{7}{|l|}{ Auxiliary Areas } \\
\hline VFS $(g)$ & $<10$ & $2-20$ & 200 & $<5$ & $1-10$ & 100 \\
\hline HOT LABS & $<5$ & $1-10$ & 100 & $<1$ & $05-5$ & 10 \\
\hline $\operatorname{STACK}^{(h)}$ & $<5$ & $1-10$ & 100 & $<5$ & $1-10$ & 100 \\
\hline
\end{tabular}

(a) After completion of final operational clearout flushes

(b) Total Pu 15 estimated to be $87 \mathrm{~kg}$

(c) Total Pu is estimated to be $70 \mathrm{~g}$

(d) Water in pool acts as shrelding for hot spots

(e) In plutonium nitrate cells and glove boxes

(f) Excluding filters Readings on filters may be as $h$ igh as $1000 \mathrm{R} / \mathrm{hr}$

(g) In filter housing

(h) Stack not chemically decontaminated

(1) See Section 120 for definitions of letter designations 
The dose rates presented are estimates but are believed to be representati of typical values. The values encountered in a specific plant could be quite different, depending upon operating philosophy and a variety of other variables.

The radioactivity levels listed in Table 5.4-1 were used to calculate dose rates for the areas shown. These calculations formed the basis for the estimated range of doses presented in the table. Details of the residual radioactivity estimates summarized in the table are given in Volume 2, Appendix B.

The radioactivity levels presented in the table for the process cells include allowances for contamination adhering to internal surfaces of process equipment, external surfaces of process equipment and cell wal1s. Estimates of residual radionuclide inventories on external surfaces of process equipment and on the cell walls before chemical decontamination are based on postulated leaks from the process streams with the highest radioactivity content in each ce11. Contamination is assumed to accumulate at a relatively constant rate over the operating life of the plant. Approximately $85 \%$ of the contamination is postulated to be on concrete walls and $15 \%$ on stainless steel equipment. This estimate does not include the buildup of large quantities of process material or debris in the cells because these were assumed to be cleaned up as a part of normal housecleaning procedures during plant operations. The total residual plutonium in process equipment and on process cell walls in the facility is estimated to be $8.7 \mathrm{~kg}$ before chemical decontamination and $70 \mathrm{~g}$ after chemical decontamination.

Residual radioactivity in the liquid waste storage tanks includes contamination adhering to tank walls and internals, material deposited on the tank bottom and the residual solution (heel) that cannot be removed from the tanks with the installed empty-out jets. Contamination levels in other areas of the plant are estimates based on engineering judgment and experience with similar areas in the reprocessing facilities at Hanford. 
Detailed listings of the radioisotope mixtures that form the basis for the dose rate estimates in Table 5.4-1 are presented in Volume 2, Appendix B. These isotopic mixtures are based on a hypothetical mixture of LWR fuel assumed to be representative of fuels to be available for reprocessing in the year 2000. Spent fuel is assumed to be reprocessed 1.5 years after reactor discharge. The feed to the reprocessing plant is $2 / 3$ PWR fuel and $1 / 3$ BWR fuel. About $16 \%$ of the reprocessing feed contains recycled plutonium.

\subsection{CHEMICAL INVENTORIES}

Several potentially toxic chemical compounds are used in the chemical processing operations. These compounds include nitric acid, gadolinium nitrate, tri-butyl phosphate, hydrazine, hydroxylamine and mercury. Most process chemicals are assumed to be removed prior to decommissioning. Inventories of these chemicals will therefore be limited to residuals in vessels, processing cells, and piping at the start of decommissioning. Except for nitric and hydrofluoric acids, which are used in chemical decontamination operations, no significant inventories of other toxic chemicals are anticipated in the plant when decommissioning begins. 


\section{REFERENCES}

1. Final Safety Analysis Report, Barnwell Nuclear Fuel Plant, Separations Facility, Volumes 1 through 5. Docket 50-332 (Plus amendments).

2. U.S. AEC, Final Environmental Statement Concerning Proposed Rule-Making Action: Numberical Guides for Design Objectives and Limiting Conditioning for Operation to Meet the Criteria "As Low As Practicable" for Radioactive Material in Light Water-Cooled Nuclear Power Reactor Effluents, WASH-1258, Directorate of Regulatory Standards, July 1973, Volume 1 of 3 , Figure 6B-1, page $6 \mathrm{~B}-43$ and Figure $6 \mathrm{C}-8$, page $6 \mathrm{C}-12$.

3. U.S. AEC, Final Environmental Statement Related to Operation of Monticello Nuclear Generating Plant, Docket No. 50-263, November 1972, page II-15 through II-26.

4. B. C. Finney, et a7., Correlation of Radioactive Waste Treatment cost and the Environmental Impact of Waste Effluents in the Nuclear Fuel for Use in Establishing "As Low As Practicable" Guides - Nuclear Fuel Reprocessing", ORNL-TM-4901, May 1975. Table 4.2.

5. Final General Environmental Statement on the Use of Recycle Plutonium in Mixed 0xide Fuel for Light Water Reactors, NUREG-0002, USNRC, August 1976 Volume 3 , Table IV E-8, IV E-24.

6. D. E. Larson and W. F. Bonner, Editors, High-Level Waste Vitrification by Spray Calcination/In-Can Melting, BNWL-2092, Battelle, Pacific Northwest Laboratories, Richland, WA, November 1976. 


\subsection{DISPOSITION CRITERIA}

Ultimately, the disposition of decommissioned nuclear facilities and their surrounding sites depends upon the degree to which they have been decontaminated. In turn, the level of residual contamination affects the cost of decontamination as well as the potential future use of decontaminated land and decommissioned facilities.

Examination of existing guidelines and regulations has led to the conclusion that there is a need to derive acceptable residual contamination levels that are generally applicable to decommissioned nuclear facilities and sites. It is the purpose of this section to review the existing guidance and where necessary develop an approach for deriving acceptable levels of residual contamination corresponding to each of several categories for reuse of facilities and land. To achieve this purpose, potential future intended use categories need to be defined along with the corresponding acceptable bases of residual contamination.

Some guidance currently exists on levels of radioactive contamination acceptable to NRC for termination of operating licenses. $(1,2)$ Levels of acceptable contamination specific to types of facilities or radionuclides have also been suggested by others. ${ }^{(3-8)}$ None of these existing guidelines are flexible enough to accommodate variations in the mixture of radionuclides or site specific features such as climatology, hydrology, or topography. This fact suggests that such guidance or "disposition criteria" should be based upon a more general concept, namely, that of dose or dose rate to members of the public. This philosophical basis is fundamentally more sound than current guidance, in that acceptable residual contamination levels developed using this concept are directly reflective of the potential risk to the exposed individuals.

The primary information in this section includes a discussion of dose limits that could be applicable to the unconditional release of a decommissioned facility and/or site, and the technical approach and assumptions for relating acceptable dose rates to residual surface radioactive contamination levels from prior nuclear use. The discussion also includes the app?ication 
of this method to the decommissioning of the reference FRP described in this report, and finally a comparison of the disposition criteria developed for the FRP to existing guidance on acceptable levels of radioactive contamination.

\subsection{EXISTING GUIDANCE}

There are no unique regulations or specific guidance on acceptable maximum annual dose to individuals living on or near a decommissioned site. Guidance that could be interpreted as dose limit recommendations specifically for the cases of interest here include:

1. Recommendations of the International Committee on Radiation Protection (ICRP), Publication $9^{(9)}$

2. Surgeon Generals' Guidelines (DHEW) $(10)$

3. Appendix I of 10 CFR 50, Guides for Design Objectives for Light-WaterCooled Nuclear Power Reactors (NRC) (11)

4. Federal Guidance for the Environmental Limits of Plutonium Contamination in Soil, DRAFT ${ }^{(a)}$ (EPA) ${ }^{(12)}$

5. 40 CFR 190 Environmental Radiation Protection Requirements for Normal Operations of Activities in the Uranium Fuel Cycle (EPA).

It is not within the scope of this study to recommend dose limits for the exposure of the public to radioactive materials. For this study, acceptable contamination levels were calculated for a range of possible dose rate limits. The selection of this range of possible dose rate limits is not intended nor should it be implied as a recommendation for limiting exposure of the public from decommissioned nuclear facilities. It is believed, however, that the range selected in this study is near the dose rate values that might be established for decommissioned facilities.

Each of the listed regulations or guides provides limits on the dose rate to the public from nuclear facilities. As previously indicated, none of these limits are intended to apply to public safety from reuse of property having

$\overline{(a)}$ At the time of this writing, EPA's draft guidance has been revised but it is not available for reference. 
prior nuclear use. Each of the five references (9-13) suggest different maximum dose rate limits. These 1 imits generally range from maximum total body dose rates of 3 to $500 \mathrm{mrem} / \mathrm{yr}$.

An analysis of the development, cortserit and apparent intent of these documented recommendations for public exposure indicates that the two recommendations that fall into the 400 to $500 \mathrm{mrem} / \mathrm{yr}$ range $(9,10)$ are largely ignored in more recent standard setting methodologies. The remainder of the recommendations range from 3 to $75 \mathrm{mrem} / \mathrm{yr}$ maximum annual dose to members of the public. A more detailed review of these five reference is found in Appendix D.

The environmental standards for the uranium fuel cycle proposed by EPA ${ }^{(13)}$ implicitly contain assumptions related to the benefits expected to accrue as a result of the permitted exposure (i.e., $25 \mathrm{mrem} / \mathrm{yr}$ from the total fuel cycle). These same assumptions might not apply to a decommissioned site or facility. Therefore, the proposed limit of $25 \mathrm{mrem} / \mathrm{yr}$ is uséful only in the context that it may represent an upper bound to any candidate dose rate 1 imit applicable to decommissioned nuclear facilities and/or sites.

The remaining dose rate limits for which there is documented guidance range from 3 to $10 \mathrm{mrem} / \mathrm{yr}$. $(11,12)$ It is reasonable to expect that if dose limits are promulgated uniquely for the control of public exposure from decommissioned nuclear facilities, that they will probably fall in the range of the lower values, i.e., 1 to $25 \mathrm{mrem} / \mathrm{yr}$. For this reason, example disposition criteria have been developed for the reference lRP for this range of annual dose limits as a demonstration of the methodolocy. In the analysis, the annual dose limits are assumed to apply to any organ of the maximum exposed individual.

\subsection{USE CATEGORIES}

During the planning stages of decommissioning, a variety of $c_{1, t u r e}$ use options for land and facilities may be considered. In this study, however, 
three use categories are defined, together with the general types of restrictions for each that will limit púublic exposure to doses that are less than the corresponding dose limitations. ?

No attempt has been made-to 'jdeitify all of the specific uses that might fall into each category due to the many variables and combinations of variables related to the site (e.g., amount of radioactivity present before decommissioning; population and land use of the surrounding area; topography, climate, and economic potentíal). Each case should therefore be decided on an individual basis, taking these variables into account and using as a guideline the categories presented here.

Use categories for sites and facilities can be broadly classified as follows:

- Restricted Use

- Conditional Use

- Unrestricted Use

Use categories are defined in such a way as to offer options for the level of residual contamination that can be left at a facility or site. These categories and their corresponding disposition criteria (contamination levels) combine to provide a consistent level of protection for all decommissioned facilities.

\subsubsection{Use Category Selection Considerations}

Whenever the owrer of a nuclear facility decides to decommission it, he may also need to decide what its intended future use will be. Information required for the decision-making process includes:

- Planned short and potential long term future use of the site and/or facility

- Planned short and potential long term future use of the surrounding area

- Compatibility between "use category" and potential site and/or facility use

- Cost of decontaminating the site and/or facility to the level specified for the "use category." 
Once this information is reasonably well established, the category and corresponding residual radioactive contamination limit that is consistent with future use, safety, and economics can be selected.

\subsubsection{Restricted Use}

The Restricted Use category permits reuse of facilities and land for nuclear activities only. For this category, it is expected that the radioactive contamination levels at the facility and its site will be similar to the levels normally found at operating nuclear facilities. Therefore, the controls imposed for classification in this use category should be consistent with licensing requirements for nuclear facilities.

\subsubsection{Conditional Use}

Conditional Use is an interim category which permits limited use of a facility and/or its site until it can be released unconditionally. Sufficient use restrictions including physical barriers where necessary, must be provided to avoid exposure of the members of the public to radiation levels in excess of those permitted in the Unrestricted Use category. Conditional release of facilities for uses other than nuclear use will most 1 ikely require a possession-onty license.

Conditional use categories do not exist in regulations or guidance currently offered by regulatory agencies. It is the authors opinion that if desirable for financial or other reasons, such a category could exist with no compromise to public safety. It is expected that release of facilities or lands for conditional use would be rare and only in cases where control can be assured. The annual dose limit for this category is the same as the unrestricted release category. The fact that identification and definition of such a category is not currently found in Federal Regulations is not meant to suggest a deficiency or that such a category should be created but merely to suggest the possibility that viable interim use of land and/or facilities may exist that could create better options for all parties concerned.

Residual contamination limits for the Conditional Use category will depend on the legal and administrative controls and physical barriers established as a contingency to the release of the facility and/or site. At a 
nuclear facility, there are likely to be buildings or even rooms within a building that could be released for non-nuclear uses provided that physical barriers and contingency restrictions are erected or designed to limit public exposures sufficiently to meet the Unrestricted Use category conditions. An example of this situation might be administrative offices located at large canyon buildings. By placing sufficient physical barriers, isolating ventilation systems and requiring periodic radiation surveys these offices could be conditionally released for non-nuclear uses.

In short, the Conditional Use category permits higher residual contamination levels than the Unrestricted Use category, providing that barriers and controls will limit potential doses to members of the public to no greater than those established for the Unrestricted Use category. It is an interim category.

\subsubsection{Unrestricted Use}

Unrestricted release of facilities and/or land necessarily means that the potential dose rate to users from all possible exposure pathways of this property will not exceed appropriate limits as may be defined by Federal regulatory agencies. Since no constraints are placed upon the use of property in this category, all potential exposure pathways for members of the public must be considered in establishing the allowable levels of residual radioactive contamination. For land, consideration should be given to people living directly on previously contaminated areas, growing crops, grazing food animals and using well water. If the potential dose rate to any member of the public demonstrated by the analysis of all these pathways is less than the dose limits, then an unrestricted release can be justified.

Unrestricted release of decommissioned nuclear facilities must also consider all potential exposure pathways. In addition to floors, walls and ceilings, normally inaccessible areas such as piping, sumps, sewers, ventilation systems, and other dead-leg areas should be reduced in contamination levels accordingly. Inability to either reduce the contamination in these areas, or to monitor them for compliance would preclude the unrestricted release of the facility. 


\subsection{TECHNICAL APPROACH}

The basic premise for proposed disposition criteria in this study is that no member of the public will receive a dose at a rate in excess of the maximum annual dose, once that limit is established. That is, under no foreseeable circumstance will the predicted dose rate to any member of the public be permitted to exceed the dose rate specified for the Unrestricted Use category.

\subsubsection{Logic}

Numerical values can be derived for residual contamination levels corresponding to acceptable dose limits. This information can then be used to determine acceptable combinations of levels of radioactivity contamination for facilities and/or sites and their allowable use.

The logic used for developing the disposition criteria for the reference FRP is shown in Figure 6.3-1.

The required formulation, data, and decisions necessary to derive dosebased acceptable residual contamination levels are identified. As shown by Figure 6.3-1, the output of this study is criteria for the reference FRP. Characteristics for a specific facility and/or site can be input into the logic and disposition criteria unique for the specific conditions of other facilities and/or sites can be derived.

Assuming that dose rate limits will be defined, a formulation was derived for relating radioactive contamination levels to potential maximum annual doses to a maximum exposed individual. The formulation includes the exposure pathways to man usually evaluated (i.e., external radiation, inhalation and ingestion. A discussion and derivation of these formulations and implicit assumptions can be found in Appendix F-4.

Upon developing this relationship, disposition criteria (for a range of doses) were developed for the unrestricted release of property. Since some criteria already exist for the range of "acceptable contamination levels", a comparison is made to check consistency of the values from this study with previous guidance. If the values derived here are dissimiliar to existing guidance, justification must be developed for departing from these already accepted values. 


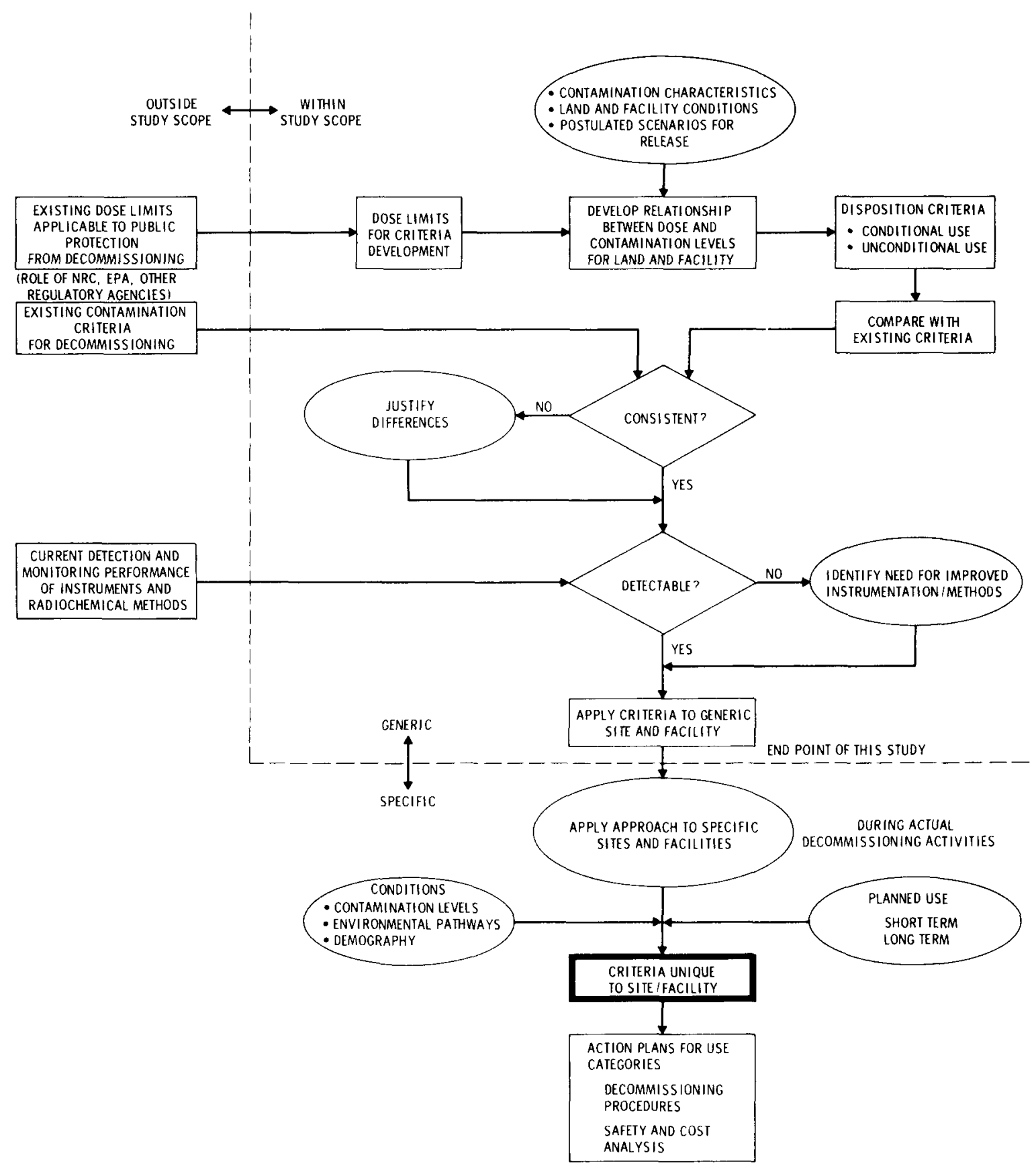

\section{FIGURE 6.3-1. Logic Diagram for the Development and Application of Disposition Criteria for Decommissioned Nuclear Facili- ties and Sites}


As illustrated in the Figure, 6.3-1, detectability of the residual contamination is an influencing factor in the development of acceptable residual contamination levels. If acceptable criteria are developed that fall below current detection levels, improved instrumentation or radiochemical analys is methods may have to be developed.

\subsubsection{Disposition Criteria Calculation}

Using the dose rate/contamination formulation previously mentioned and discussed in Appendix D disposition criteria were developed for portions of the reference FRP and site to assist in the planning and cost evaluation. As shown by Figure 6.3-1, input specific to the conditions of the facility or site are necessary to perform the calculations. Information needs include the specific mixture of radionuclides at the time of planned decommissioning, and site characteristics such as climatology, ecology, hydrology, demography, and topography.

Based upon the preceding information, the maximum annual dose to a maximum exposed individual can be evaluated for potential exposure pathways. A calculation is made using a unit inventory of the radionuclide mixture, establishing a relationship between the annual dose to the maximum exposed individual and contamination level. This relationship, established for each exposure pathway, forms the basis for determining the acceptable residual contamination level or disposition criterion.

Atmospheric releases from ground contamination, used in the dose calculations for radioactive material deposited internally in people, were derived by applying a time dependent factor developed by Anspaugh et al. (14) to analytically correct the resuspension for weathering. The initial resuspension factor used was $10^{-8}$ per meter. The resulting relationship is graphically displayed in Figure 6.3-2. The models used to calculate the maximum annual dose from the release of this contamination are essentially the same as those used by the NRC. (15) A description of the models used and the computer codes to implement the calculations is found in Appendix F.4.

The dose calculations for external radiation exposure use the methodology developed by Fitzgerald. (16) The direct exposure portion of the dose calculation is performed assuming that the maximum exposed individual is located at 


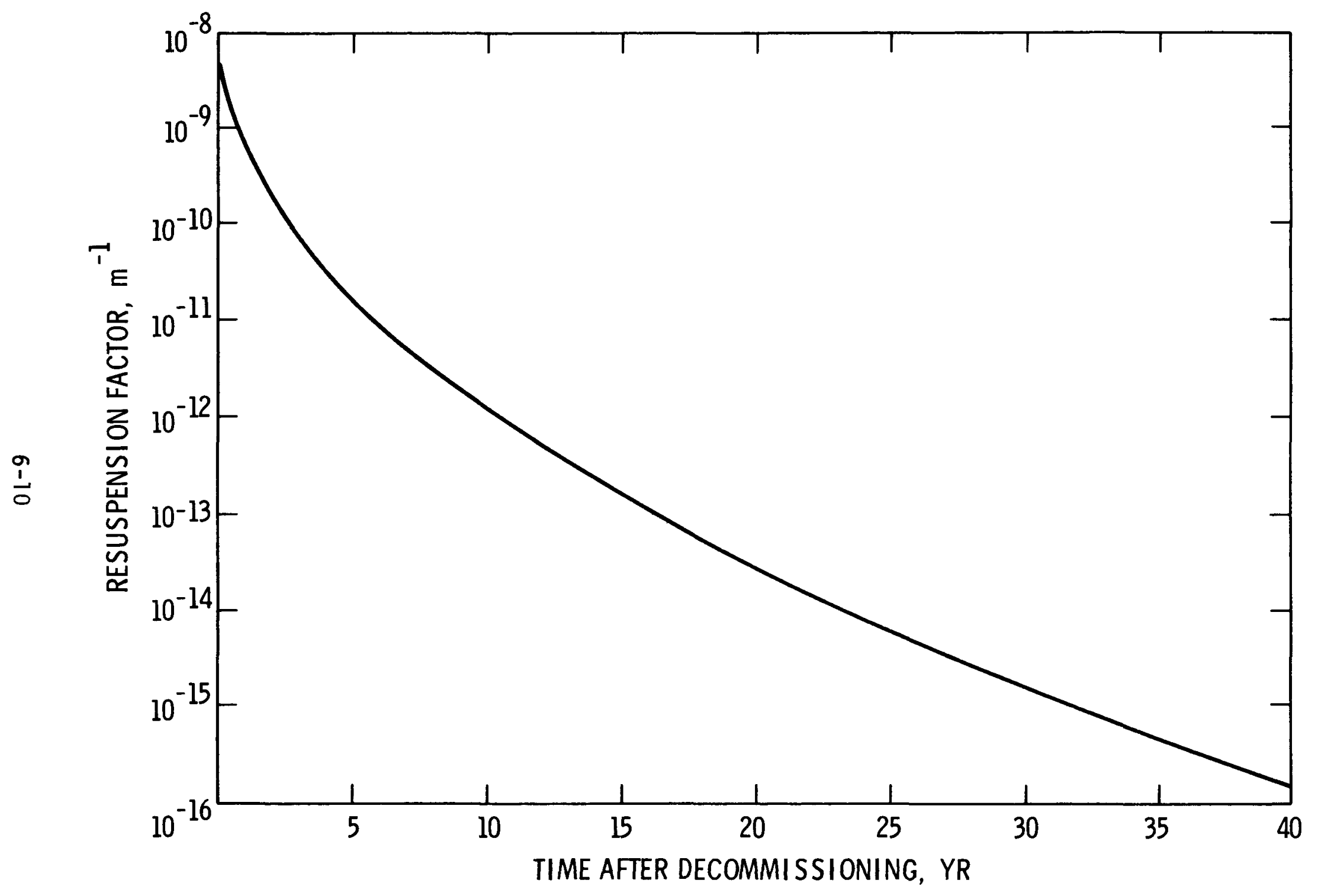

FIGURE 6.3-2. Resuspension Factor as a Function of Time 
the site center or at the center of the floor of a large room within the facility. In this way, the site acts as an infinite disc and the facility as a large plane source. Time spent offsite was assumed to reduce the time of exposure to radiation of individuals to $12 \mathrm{hr} /$ day.

For the inhalation exposure pathway, the dose is maximized by locating the individual on the site where he is continuously exposed and continualiy inhales the contamination as it is resuspended. For the ingestion pathway it is assumed that an individual ingests farm products grown on the site. These products are assumed to be contaminated by root uptake and by the deposition of resuspended material. Ingestion, the more dominant of the two pathways, is maximized by this scenario.

Dose calculated for the potential pathways, including submersion in the resuspended contaminated cloud, are then summed as appropriate for total dose to organs of reference. State-of-the-art data are used in the calculations for meteorological dispersion, resuspension, and biological transfer factors.

\subsection{DISPOSITION CRITERIA}

Disposition criteria for unrestricted release of both the site and a room in the reference FRP are given in this subsection. Acceptable residual contamination levels are shown for maximum annual dose rates of 1 and $25 \mathrm{mrem} / \mathrm{yr}$. Based upon this information, judgments were made in Section 7 of this report on the planned decommissioning action necessary to release the site and parts of the FRP for unrestricted use. These values were compared to the radioactive contamination levels predicted at the time of shutdown (Section 5) so appropriate decommissioning plans consistent with intended reuse could be made.

\subsubsection{Site}

The residual contamination levels for the site are shown in Table 6.4-1. It can be seen from this table that the allowable residual contamination levels (in units of $\mu \mathrm{Ci} / \mathrm{m}^{2}$ mixed to a depth of $15 \mathrm{~cm}$ in soil) (a) are limited by the dose to the thyroid gland. This is true for each time period after shutdown (up to 100 years) as well as at plant shutdown. The corresponding

(a) See Volume 2, Appendix D, Section D.2.2 
TABLE 6.4-1. Residual Contamination Levels at a Generic Site(a) Corresponding to Candidate Dose Criteria at Selected Times after Shutdown

\begin{tabular}{|c|c|c|c|}
\hline \multirow{2}{*}{$\begin{array}{c}\text { Time After } \\
\text { Shutdown } \\
\text { (years) } \\
\end{array}$} & \multirow{2}{*}{$\begin{array}{r}\text { Organ of } \\
\text { Reference } \\
\end{array}$} & \multicolumn{2}{|c|}{$\begin{array}{l}\text { Deposition; } \mu \mathrm{Ci} / \mathrm{m}^{2} \text { Corresponding } \\
\text { to a Maximum Annual Dose }(\mathrm{b}) \text { of: }\end{array}$} \\
\hline & & $1 \mathrm{mrem} / \mathrm{yr}$ & $25 \mathrm{mrem} / \mathrm{yr}$ \\
\hline \multirow[t]{4}{*}{0} & Lungs & $1.5 \mathrm{E}+0^{(c)}$ & $3.8 E+0$ \\
\hline & Whole Body & $3.2 \mathrm{E}-1$ & $8.0 E+0$ \\
\hline & Bone & $9.3 \mathrm{E}-2$ & 2. $3 E+0$ \\
\hline & Thyroid & $8.2 E-3$ & $2.1 E-1$ \\
\hline \multirow[t]{4}{*}{10} & Lungs & 2. $2 E+0$ & $5.5 E+1$ \\
\hline & Whole Body & $2.6 \mathrm{E}-1$ & $6.5 E+0$ \\
\hline & Bone & $7.5 E-2$ & $1.9 E+0$ \\
\hline & Thyroid & $5.6 \mathrm{E}-3$ & $1.4 E-1$ \\
\hline \multirow[t]{4}{*}{30} & Lungs & $2.4 E+0$ & $6.0 \mathrm{E}+1$ \\
\hline & Whole Body & $3.1 \mathrm{E}-1$ & $7.8 E+0$ \\
\hline & Bone & $9.0 \mathrm{E}-2$ & $2.3 \mathrm{E}+0$ \\
\hline & Thyroid & $4.3 E-3$ & $1.1 \mathrm{E}-1$ \\
\hline \multirow[t]{4}{*}{100} & Lungs & $3.3 E+0$ & $8.3 E+1$ \\
\hline & Whole Body & $7.4 \mathrm{E}-1$ & $1.9 E+1$ \\
\hline & Bone & $3.2 E-1$ & $8.0 \mathrm{E}+0$ \\
\hline & Thyroid & $3.2 E-3$ & $8.0 \mathrm{E}-2$ \\
\hline
\end{tabular}

\footnotetext{
(a) Mixed to a soil depth of $15 \mathrm{~cm}$. See Volume 2, Appendix D, Section D.2.2.

(b) Includes dose from all potential exposure pathways.

(c) $1.5 \mathrm{E}-2=1.5 \times 10^{-2}$
}

disposition criteria based on the thyroid gland as the organ of reference for these decay times, are highlighted in Table 6.4-2. A comparison of Table 6.4-1 and Table 5.1-1, Section 5, indicates that the potential contamination levels on the site at the time of shutdown may be in excess of levels judged to be acceptable for unrestricted release of the site. 
TABLE 6.4-2. Residual Contamination Levels at a Generic Site Corresponding to Candidate Dose Criteria with the Thyroid Gland as the Organ of Reference

\begin{tabular}{|c|c|c|}
\hline \multirow{2}{*}{$\begin{array}{c}\text { Time After } \\
\text { Shutdown } \\
\text { (years) } \\
\end{array}$} & \multicolumn{2}{|c|}{$\begin{array}{l}\text { Deposition, } \mu \mathrm{Ci} / \mathrm{m}^{2} \text { Corresponding } \\
\text { to a Maximum Annual Dose(a) of: }\end{array}$} \\
\hline & $1 \mathrm{mrem} / \mathrm{yr}$ & $25 \mathrm{mrem} / \mathrm{yr}$ \\
\hline 0 & $8.2 E-3$ & 2. $1 \mathrm{E}-1$ \\
\hline 10 & $5.6 E-3$ & $1.4 \mathrm{E}-1$ \\
\hline 30 & $4.3 E-3$ & 1. $7 E-1$ \\
\hline 100 & $3.2 \mathrm{E}-3$ & 8.0E-2 \\
\hline
\end{tabular}

For the generic site and assumptions used in this study, it is concluded that the disposition criterion, considering all significant exposure pathways is in the range of $8.2 \times 10^{-3}$ to $8.0 \times 10^{-2} \mu \mathrm{Ci} / \mathrm{m}^{2}$ depending on the time after shutdown when decommissioning is to be initiated and upon the dose limit selected.

Several actions are possible to permit conditional release of the site. Ingestion, specifically ingestion of ${ }^{129}$ I via leafy vegetables and cow's milk is the most restrictive pathway and results in the lowest allowable residual contamination levels. A reduction of the thyroid gland dose can be achieved by controlling farming on the site. As an example of releasing the site for Conditional Use, allowable residual contamination levels were calculated assuming no farm products would be permitted to be grown on the released site. The resulting allowable residual contamination levels listed in Table 6.4-3 indicate that the allowable residual contamination levels are still controlled by the dose to the thyroid gland, however, these levels are now considerably higher as highlighted in Table 6.4-4.

If unrestricted release is required for the land, some form of decontamination may be necessary to reduce the residual contamination levels to below those judged to be acceptable. Techniques such as excavation and removal of all vegetation may be used where radioiodine is limiting. 
TABLE 6.4-3. Residual Contamination Levels at a Generic Site(a) Corresponding to Candidate Dose Criteria at Selected Time after Shutdown. Conditional Use No Farm Products

Time After Shutdown (years)

0

10

30
Organ of

Reference

Whole Body

Bone

Lungs

Thyroid

Whole Body

Bone

Lungs

Thyroid

Whole Body

Bone

Lungs

Thyroid

Whole Body

Bone

Lungs

Thyroid
Deposition, $\mu \mathrm{Ci} / \mathrm{m}^{2}$ Corresponding to a Maximum Annual Dose (b) of:

$1 \mathrm{mrem} / \mathrm{yr} \quad 25 \mathrm{mrem} / \mathrm{yr}$

$$
6.3 \mathrm{E}-1 \quad 1.6 \mathrm{E}+1
$$

$6.3 \mathrm{E}-1$

$1.6 \mathrm{E}+1$

4.3E-1

1. $1 E+7$

4. $4 \mathrm{E}-2$

$1.1 E+0$

$5.3 \mathrm{E}-1$

1. $3 \mathrm{E}+1$

$5.3 \mathrm{E}-1$

1. $3 E+7$

$3.0 \mathrm{E}-1$

7. $5 \mathrm{E}+0$

4. $4 \mathrm{E}-2$

$1.1 E+0$

$3.7 \mathrm{E}-1$

9. $3 E+0$

$6.6 \mathrm{E}-1$

$1.7 \mathrm{E}+1$

$3.2 \mathrm{E}-1$

8. $0 \mathrm{E}+0$

$5.5 \mathrm{E}-2$

$1.4 E+0$

4.5E-1

$1.7 \mathrm{E}+1$

$1.6 \mathrm{E}+0$

$4.0 \mathrm{E}+1$

4. $0 \mathrm{E}-1$

$1.0 E+1$

$1.4 \mathrm{E}-1$

$3.5 \mathrm{E}+0$

(a) Surface contamination. See Volume 2, Appendix D, Section D.2.2.

(b)

Excludes dose from ingestion pathway.

It should be noted that the reference site residual contamination levels at shutdown reflected by Table 5.1-1, are most likely higher than might be expected by nature of the assumptions used to make the calculation. The primary reason for the calculated contamination levels being higher than the expected values is that no credit was taken for weathering of the contamination, either during the $30 \mathrm{yr}$ plant life or at any time thereafter. For this reason, no decommissioning plan was developed for the land at the reference 
TABLE 6.4-4. Residual Contamination Levels at a Generic Site Corresponding to Candidate Dose Criteria with the Thyroid Gland as the Organ of Reference. Conditional Use - No Farm Products

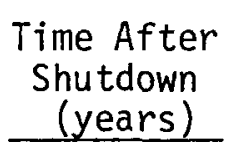

0

10

30

100

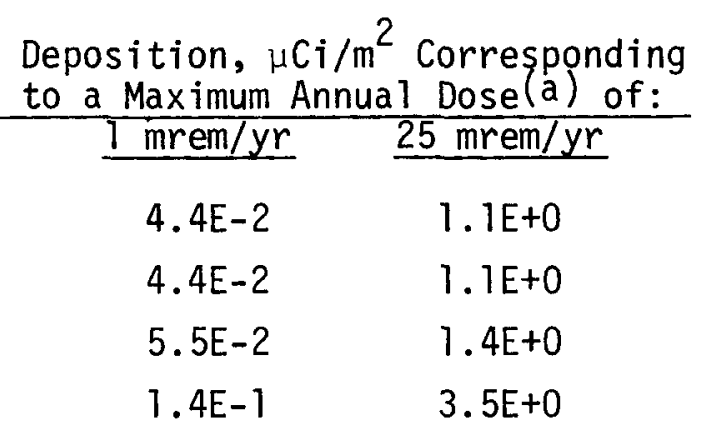

1. $4 \mathrm{E}-1 \quad 3.5 \mathrm{E}+0$

(a) Excludes dose from ingestion pathway.

site. Methods are available for such decontamination and have been previously demonstrated for accident situations. For a specific site, comprehensive site measurements will be necessary at shutdown to appropriately characterize the existing contamination levels at sites for planned action.

\subsubsection{Facility}

The isotopic composition of the contamination levels in the generic facility were based on an inventory described in Appendix $B$. The annual dose rate was calculated by models described in Appendix F.4 and using residual contamination levels of $1 \mu \mathrm{Ci} / \mathrm{m}^{2}$ composed of the radionuclides present at shutdown and for selected decay times thereafter. The only exposure pathways considered here were inhalation of resuspended material and external exposure to radiation emanating from contaminated surfaces. 0ccupancy of the building spaces was based on a 40-hr work week. A resuspension factor from room surfaces of $5 \times 10^{-6} \mathrm{~m}^{-1}$ was assumed for estimating air concentrations in the room. This value is one-tenth of the value suggested in an IAEA study for surfaces with removable contamination. (17) A value lower than the IAEA value is assumed here because the unrestricted release of facilities should not be contemplated with readily removable contamination remaining on accessable surfaces. Actual resuspension factors from decontaminated room surfaces may 
be considerable lower than the one selected. However, the selected value conservative in that is maximizes the annual dose rate to the organs of reference used in this study. Measurements at a decontaminated facility to determine the actual air concentrations encountered may well alter the allowable residual surface contamination levels calculated here.

The relationship between surface contamination in the facility and dose to workers in a non-nuclear use industry was then used to calculate the allowable residual contamination levels corresponding to previously discussed range of annual dose limits, i.e., a maximum acceptable annual dose of 1 to $25 \mathrm{mrem}$. The resulting contamination levels are listed in Table 6.4-5.

From Table 6.4-5 it is concluded the annual dose to the lungs best determines the allowable residual contamination level. These levels are highlighted in Table 6.4-6.

Conditional release of an FRP would most likely involve selective release of rooms and/or auxiliary buildings which could be shown to have less than the allowable residual contamination levels listed in Table 6.4-6. It would be difficult to impose conditions that would el iminate exposure from one or more of the exposure pathways considered in the reference FRP. Because this is an example calculation only, no comparison is made of the facility disposition criteria to any calculated contamination levels in the reference plant (see Section 5 and Appendix $B$ for an indication of the expected levels of residual contamination in the facility at shutdown).

\subsubsection{Disposition Criteria for Equipment and Material}

The standards developed by the ANSI Committee N328 are adopted for decommissioning equipment in this generic study. Actually, the complexities of decontaminating equipment are great and the generic treatment of this problem is difficult. In an actual case each piece of equipment will have to be dealt with as an individual case.

\subsection{SUMMARY OF EXISTING GUIDANCE AND EXAMPLE DISPOSITION CRITERIA}

Existing authoritative guidance is found in Regulatory Guide $1.86(1)$ and the proposed ANSI Standard N328. (8) The levels judged by these references to be acceptable for unrestricted release are summarized in Tables 6.5-1 and 6.5- 
TABLE 6.4-5. Residual Contamination Levels Within the Reference Facility Corresponding to Candidate Dose Criteria at Selected Times after Shutdown

\begin{tabular}{|c|c|c|c|}
\hline $\begin{array}{l}\text { Time After } \\
\text { Shutdown }\end{array}$ & Organ of & $\begin{array}{l}\text { Deposition, } \mu \\
\text { to a Maximum }\end{array}$ & $\begin{array}{l}2 \text { Corresponding } \\
\text { a Dose }(a) \text { of }\end{array}$ \\
\hline (years) & Reference & $1 \mathrm{mrem} / \mathrm{yr}$ & $25 \mathrm{mrem} / \mathrm{yr}$ \\
\hline 0 & Thyroid & $83 E-1$ & $2 T E+7$ \\
\hline & Whole Body & $42 E-1$ & $11 E+1$ \\
\hline & Bone & $2 O E-2$ & $50 E-1$ \\
\hline & Lungs & $14 \mathrm{E}-2$ & $35 \mathrm{E}-1$ \\
\hline 10 & Thyroid & $17 E$ & $43 E+1$ \\
\hline & Whole Body & $46 E-1$ & $12 E+1$ \\
\hline & Bone & $2 O E-2$ & $50 E-1$ \\
\hline & Lungs & $15 E-2$ & $38 \mathrm{E}-1$ \\
\hline 30 & Thyroid & $29 E+0$ & $73 \mathrm{E}+1$ \\
\hline & Whole Body & $53 E-1$ & $13 E+1$ \\
\hline & Bone & $20 E-2$ & $50 \mathrm{O}-1$ \\
\hline & Lungs & $17 \mathrm{E}-2$ & $43 E-1$ \\
\hline 100 & Thyroid & $17 E+1$ & $28 E+2$ \\
\hline & Whole Body & $67 E-1$ & $17 \mathrm{E}+1$ \\
\hline & Bone & $23 E-2$ & $58 \mathrm{E}-1$ \\
\hline & Lungs & $20 E-2$ & $50 E-1$ \\
\hline
\end{tabular}

TABLE 6.4-6. Residual Contamination Levels Within the Reference Facility Corresponding to Candidate Dose Criteria with the Lung as the Organ of Reference

\begin{tabular}{|c|c|c|}
\hline $\begin{array}{l}\text { Time After } \\
\text { Shutdown }\end{array}$ & $\begin{array}{l}\text { Deposition, } \mu \\
\text { to a Maximum }\end{array}$ & $\begin{array}{l}\text { Corresponding } \\
1 \text { Dose }(a) \text { of: }\end{array}$ \\
\hline (years) & $1 \mathrm{mrem} / \mathrm{yr}$ & $25 \mathrm{mrem} / \mathrm{yr}$ \\
\hline 0 & $1.4 \mathrm{E}-2$ & $3.5 \mathrm{E}-1$ \\
\hline 10 & $1.5 \mathrm{E}-2$ & $3.8 \mathrm{E}-1$ \\
\hline 30 & $1.7 \mathrm{E}-2$ & $4.3 \mathrm{E}-1$ \\
\hline 100 & $2.0 \mathrm{E}-2$ & $5.0 \mathrm{E}-1$ \\
\hline
\end{tabular}

(a) Exciudes dose from ingestion pathways 
$\frac{\text { Nuclide }(a)}{U-n a t,{ }^{235} U, 238_{U} \text { and associated }}$ decay products

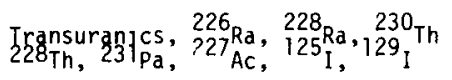

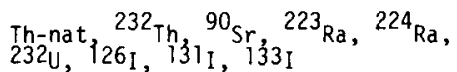

Beta-ganma emitters (nuclides with decay modes other than alpha emission or spontaneous fission) except $90 \mathrm{Sr}$ and others noted above

\author{
Average ${ }^{(b, c)}$ \\ $5,000 \mathrm{dpm} \alpha / 100 \mathrm{~cm}^{2}$
}

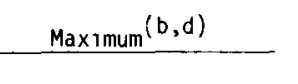

$100 \mathrm{dpm} / 100 \mathrm{~cm}^{2}$

$1000 \mathrm{dpm} / 100 \mathrm{~cm}^{2}$

$300 \mathrm{dpm} / 100 \mathrm{~cm}^{2}$

$3000 \mathrm{dpm} / 100 \mathrm{~cm}^{2}$

$20 \mathrm{dpm} / 100 \mathrm{~cm}^{2}$

$200 \mathrm{dpm} / 100 \mathrm{~cm}^{2}$

\footnotetext{
(a) Where surface contamination by both alpha- and beta-gamma-emitting nuclides exists, the $11 \mathrm{~m}$ ts established for alpha- and beta-gama-emitting nuclides should apply independently

(b) As used in this table, dpm (disintegrations per minute) means the rate of emission by radioactive material as determined by correcting the counts per minute observed by an appropriate detector for background, efficiency, and geometric factors associated with the instrumentation

(c) Measurements of average contaminant should not be averaged over more than 1 square meter For objects of less surface area, the average should be derived for each such object

(d) The maximum contamination level applies to an area of not more than $100 \mathrm{~cm}^{2}$

(e) The amount of removable radioactive material pel $100 \mathrm{~cm}^{2}$ of surface area should be determined by wiping that area with dry filter or soft absorbent paper, applying moderate pressure, and assessing the amount of radioactive material on the wipe with an appropriate instrument of known efficiency When removable contamination on objects of less surface area is determined, the pertinent levels should be reduced proportionaliy and the entire surface should be wiped
}

\section{TABLE 6.5-2. ANSI N328 Surface Contamination Limits (Proposed)}

\section{Group 1}

Nuclides for which the nonoccupational MPC $(b)$ is $2 \times 10^{-13} \mathrm{Cl} / \mathrm{m}^{3}$ or less or for which the nonoccupational $\mathrm{MPC}_{\mathrm{W}}(\mathrm{c})$ is $2 \times 10^{-7} \mathrm{C}_{1} / \mathrm{m}^{3}$ or less (d)

Group 2

Those nuclides not in Group 1 for which the nonoccupational $\mathrm{MPC}_{\mathrm{a}}(\mathrm{b})$ is $1 \times 10^{-12} \mathrm{C} / \mathrm{m} \mathrm{m}^{3}$ or less or for which the nonoccupational $M P C_{w}(c)$ is $1 \times 10^{-6} \mathrm{c} 1 / \mathrm{m}^{3}$ or less $(d)$

Group 3

(a) The levels may be averaged over one square meter, provided the maximum activity in any area of $100 \mathrm{~cm}^{2}$ is less than 3 times the limit value

(b) Maximum permissible concentration in air applicable to continuous exposure of members of the public as published by or derived from an author7 tative source such as NCRP, ICRP or NRC (10 CFR Part 20, Appendix B, Table 2, Column 1)

(c) Maximum permissible concentration in water applicable to memebers of the public

(d) Values presented here are obtained from 10 CFR Part 20 The most 11miting of all given MPC values (e g , soluble vs insoluble) are to be used In the event of the occurrence of mixtures of radionuclides, the fraction contributed by each constituent of its own $11 \mathrm{mit}$ shall be determined and the sum of the fractions must be less than 1 
Ranges of disposition criteria developed in this study are listed in Table 6.5-3. The methodology used in deriving these values is flexible enough to accommodate variations in mixtures of radionuclides, and, at the same time, be site specific. Therefore, the values listed in Table 6.5-3 are not directly comparable to those promulgated by either Regulatory Guide 1.86 or ANSI N328. These values reflect the possible range in annual dose 1 imit and the time after shutdown at which decommissioning is comtemplated. The lower value of this range corresponds to the lower annual dose 1 imit of $1 \mathrm{mrem}$ per year while the upper limit of the range corresponds to 25 mrem per year. Ranges are given for decommissioning immediately after shutdown and for decommissioning occurring 100 years later.

TABLE 6.5-3. Allowable Residual Contamination Levels Derived for the Reference Fuel Reprocessing Plant Located at a Generic Site

\begin{tabular}{cc} 
Time After & $\begin{array}{c}\text { Allowable Residual Contamination } \\
\text { Levels, dpm/100cm2(a) for an } \\
\text { Annual Dose Limit of: }\end{array}$ \\
\cline { 2 - 2 } Shutdown, years & 1 mrem/yr $25 \mathrm{mrem} / \mathrm{yr}$ \\
\hline
\end{tabular}

Site

(Unrestricted Use)

$\begin{array}{rrr}0 & 200 & 5,000 \\ 100 & 70 & 2,000\end{array}$

Site

(Conditional Use)

$\begin{array}{rll}0 & 1,000 & 20,000 \\ 100 & 3,000 & 80,000\end{array}$

Facility

(Unrestricted Use)

0

100
300

400
8,000

10,000

\section{(a) 111 values have been rounded to one significant figure}

For the unrestricted release of the site the dose to the thyroid gland is 1 imiting and ingestion is the primary exposure path. Since ${ }^{129} I$ is the principal radionuclide causing the dose, there is relatively little change in the annual dose to the thyroid gland throughout the one hundred year span. 
The ground deposition of all radionuclides in the reference mixture however, decreases by a factor of about $1 / 3$. Therefore, the allowable residual contamination levels at 100 years after shutdown are about $1 / 3$ of those at shutdown.

In the conditional release case, the dose to the thyroid gland is still limiting. The exposure pathway is now external exposure to ground deposited radionuclides since the ingestion pathway has been eliminated as a condition of the release. In this case, the annual dose to the thyroid gland decreases over the 100 year span to about 1/10 of the annual dose immediately following shutdown. Here again, the ground deposited contamination has decreased by a factor of $1 / 3$ so that the allowable level of residual contamination at 100 years after shutdown is approximately $10 / 3$ of the allowable level immediately after shutdown.

For the reference facility, only the unrestricted release case was considered. Furthermore, it is assumed that all surface contamination within the reference facility is removable albeit at a greatly reduced rate from the removable fraction considered in either Regulatory Guide 1.86 or ANSI draft standard N328. This assumption results in maximizing the annual dose to reference organs from inhalation. Here again the criteria are presented as a range. If it is assumed that all residual surface contamination is fixed, i.e., that inhalation is not a probable exposure pathway, then the range of allowable residual contamination levels immediately after shutdown, would be 20,000 to $500,000 \mathrm{dpm}$ per $100 \mathrm{~cm}^{2}$. Acceptance of the assumption of permenant fixation is not recommended; however, because of the paucity of data to support this position.

\subsection{MEASUREMENT CAPABILITY}

The surface contamination levels given in Tables $6.5-1,-2$ and -3 for direct measurements can for the most part be detected by commercialiy available portable instrumentation, at least in low-background locations. Table 6.6-1 shows nominal detection levels for several typically-used instruments. However, minimum detection levels for direct surveys with such instrumentation are generaliy limited to the equivalent of the background reading at the survey location (i.e., a detection level of $100 \mathrm{~d} / \mathrm{m}$ per detector area above a background level of $100 \mathrm{~d} / \mathrm{m}$ per detector area). 
TABLE 6.6-1. Detection Capabilities for Direct

Surveys with Portable Instruments

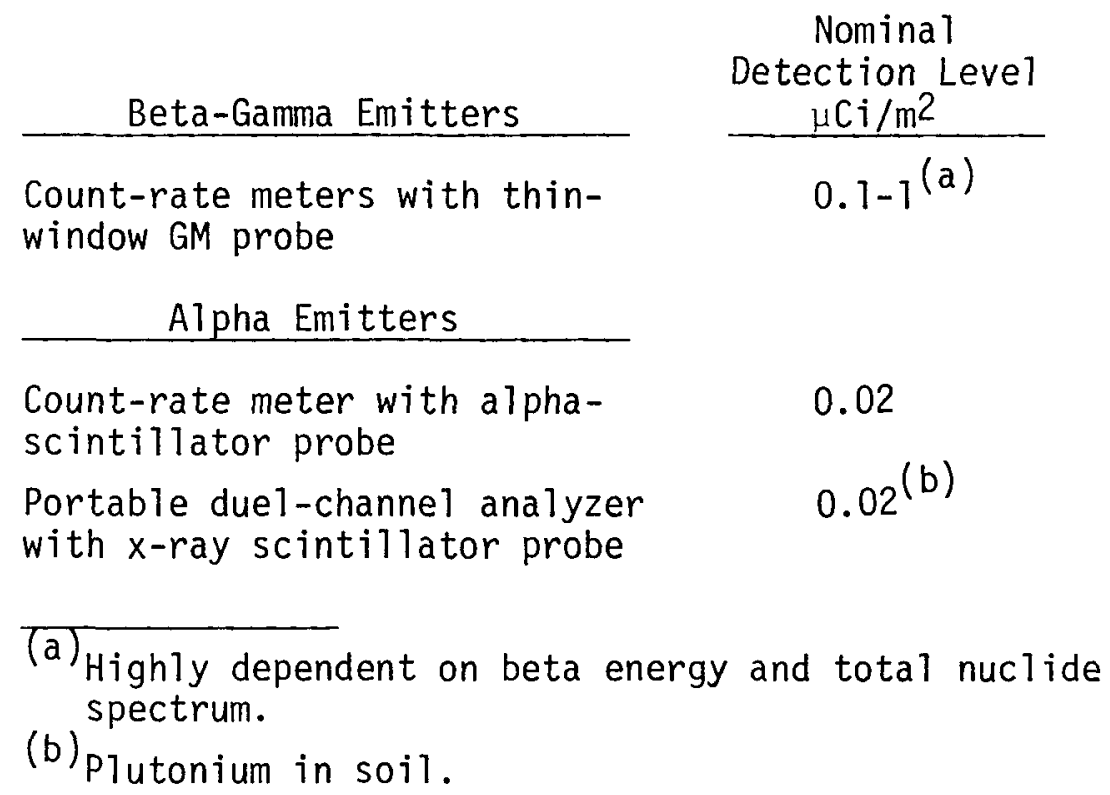

Inside generally-contaminated spaces, in the presence of large contaminated equipment items, or over large generally-contaminated surfaces, it may be necessary to resort to indirect survey methods to measure required release levels. On hard nonporous surfaces, smears or scrapings may be taken and removed to a lower-background location or preferably to laboratory counting instruments.

The 1 imits shown in the tables of Section 6.5 imply that something is known about the history of the material or the mixture of radionuclides being measured. Sampling for laboratory identification and the establishment of relationships between portable instrument measurements and specific nuclide contamination levels are highly desirable even under such conditions and necessary if preliminary information is lacking.

Sampling of bulk materials such as soils has nearly as many variations as practitioners. Practicality limits the fraction of any large area that can be sampled and analyzed. Some fixed scheme is needed for selecting sampling stations and the number, size and spacing of sample aliquots at each location, not only for appropriate statistical inferences but even for reproducibility 
and comparability. For soil the problem is further compounded by the variabi of overlying vegetation and of included rock and gravel Regulatory Guide 4.5 provides one commoniy-used scheme which is generally applicable for soil sampling. Adequate sampling of bulk materials requires sampling in depth, $30-100 \mathrm{~cm}$ in soil depending on climate and history.

There is no commonly-accepted procedure for translation of surface contamination limits to mass contamination limits or vice versa. However, with reasonable assumptions as to soil bulk density and the volume of soil seen by a portable alpha probe, the value of $0.02 \mu \mathrm{Ci} / \mathrm{m}^{2}$ shown in Table $6.6-1$ translates to approximately $0.01 \mu \mathrm{Ci} / \mathrm{kg}$ or $210^{4}$ times the LLD for laboratory analys is in Table 6.6-2. For all nuclides in environmental media, sample radioanalys is can provide far more sensitivity than is required by any of the proposed 1 imits in Section 6.5. The cost will depend on whether chemical separation is required and on the length of counting time needed to measure a particular radionuclide at a given level above instrument and sample background.

Table 6.6-3 summarizes relative advantages and disadvantages for common methods for determining surface contamination levels. Further discussion of instrument capabilities may be found in $\mathrm{LBL}-1$ (19) and of environmental survey techniques in ERDA-77-24(20) and NCRP Report No. 50, (21) as well as the health physics literature.

The recommended procedure for most release surveys consists of initial survey with portable instruments (aerial survey for large ground surface areas), in conjunction with sampling for nuclide identification or verification and quantification. 
TABLE 6.6-2. Detection Capabjlities for Environmental Sample Analysis(a)

Analysis

$3_{H}$ (HTO)

$54 \mathrm{Mn}$

${ }^{59} \mathrm{Fe}$

$58,60_{\mathrm{Co}}$

$65_{\mathrm{Zn}}$

${ }^{89} \mathrm{Sr}(\mathrm{c})$

$90_{\mathrm{Sr}}(\mathrm{c})$

${ }^{95} \mathrm{Zr}-\mathrm{Nb}$

${ }^{106} \mathrm{Ru}-\mathrm{Rh}$

$129_{\mathrm{I}}$ (c)

$131_{\mathrm{I}}$ (c)

134,137 CS

$140 \mathrm{Ba}-\mathrm{La}$

$u^{(c)}$

Pu-Alpha (c)
Lower Limit of Detection (LLD)
Water Vegetation
(pCi/l)
SoiT
(pCi/kg, Wet) (pCi/kg, Dry)

300

15

$300^{(\mathrm{c})}$

150

50

30

300

100

15

150

50

30

300

100

10

10

150

2

30

10

10

2

0.4

15

15

2

0.01

100

100

150

-.-

10

2

150

100

150

100

50

30

5

(a) This table is based on similar values given in Regulatory Guide $4.8,(22)$ with adjustments and additions reflecting current experience at a commercial radioanalytical laboratory.

(b) The normal Lower Limit of Detection is defined in HASL 300, Appendix D (Rev. 8/74),(23) at the 95\% confidence level. The LLD for radionuclides analyzed by gamma spectrometry will vary according to the number of radionuclides encountered in environmental

(c) After chemical extraction. 
TABLE 6.6-3. Comparison of Measurement Methods for Release Surveys

Direct

Portable Instruments $(a)$

Aerial Survey

Indirect

Smears, scrapings

- with direct field count

- with laboratory countting
Advantages

Relatively fast; Relatively inexpensive;

Readily available; Able to delineate "hot spots";

Extremely fast;

Avoidance of high background interference;

Relatively fast; Relatively inexpensive;

Nuclide identification possible (but more expensive); Greacer sensitivity than direct field count;

Sampling and Laboratory

Analysis
Nuclide-specific; Highly sensitive;
Disadvantages

Limited sensitivity; Not nuclide-specific; Subject to interferences from high background and surface conditions; For aipha and beta emitters, useful for exposed surfaces only;

Useful in general for gamma emitters only; (b) Insensitive to small areas;

Not indicative of total activity present; Highly variable results; Incomplete coverage of large surfaces; Not applicable to loose or confined materials;

Not nuclide-specific;

Relatively slow;

Relatively slow; Relatively expensive; Applicable only when sample of material can be taken to laboratory; Provides data for onty small part of total surface;

\footnotetext{
(a) See Table 6.6-2 for typical examples and detection levels.

(b) With special calibrations, aerial surveys may be useful for large area fo TRU, but not to release levels specified in Section 6.5.
} 


\section{REFERENCES}

1. U.S. Nuclear Regulatory Commission, Termination of Operating Licenses for Nuclear Reactors. Regulatory Guide 1.86, June 1974.

2. U.S. Nuclear Regulatory Commission, Guidelines for Decontamination of Facilities and Equipment Prior to Release for Unrestricted Use or Termination of Licenses for Byproduct, Source or Special Nuclear Material, November, 1976.

3. Code of Federal Regulations, Title 10, Part 49, "Transportation," Superintendent of Documents, GPO, Washington, DC, 20555, 1976.

4. U.S. Energy Research and Development Administration, "Prevention Control and Abatement of Air and Water Pollution." U.S. ERDA Manual, Chapter 0510, April 2, 1975.

5. J.W. Healy, A Proposed Interim Standard for Plutonium in Soils. LA-5483MS, Los Alamos Scientific Laboratory, Los Alamos, NM, January 1974.

6. C.E. Guthrie and J.P. Nichols, Theoretical Possibilities and Consequences of Major Accidents in $233 \mathrm{U}$ and $239 \mathrm{Pu}$ Fuel Fabrication and Radioisotope Processing Plants. ORNL-344T, Oak Ridge National Laboratory, Oak Ridge, TN, 37830, Apri1 1964 .

7. A.J. Hazle and Bert L. Crist, Colorado's Plutonium-in-Soil Standard, Colorado Department of Health, Occupational and Radiological Health Division, Denver, Colorado, 1975.

8. ANSI Standard N328 (Draft), Control of Radioactive Surface Contamination on Materials, Equipment and Facilities to be Released for Uncontrolled Use, 1976.

9. "Recommendations of the International Commission on Radiological Protection," ICRP Publication 9, Pergamon Press, London, 1966.

10. Surgeon General, US Public Health Service. Surgeon General's Guidelines. "Use of Uranium Mill Tailings for Constructive Purposes." Hearings before the Subcommittee on Raw Materials of the Joint Committee on Atomic Energy, October 28 and 29, 1971.(1971), pp. 52-54.

11. Code of Federal Regulations, Title 10, Part 50, Appendix I, "Licensing of Production and Utilization Facilities." Superintendent of Documents, GPO, Washington DC, 20555, 1976.

12. Federal Guidance for the Environmental Limits of Plutonium Contamination in Soils. (Draft), Environmental Protection Agency. 
13. Code of Federal Regulations, Title 40, Part 190, "Environmental Radiation Protection Standards for Nuclear Power Operations." Superintendent of Documents, GPO, Washington DC, 20555, January 1977.

14. L.R. Anspaugh, J.H. Shinn and P.L. Phelps, Resuspension and Redistribution of Plutonium in Soils. UCRL-76419, January 1975, pp. 14-18.

15 Regulatory Guide 1.109, Calculation of Annual Doses to Man From Routine Releases of Reactor Effluents for the Purpose of Evaluating Compliance With 10CFR Part 50, Appendix I, March 1976.

16. J.J. Fitzgerald, Applied Radiation Protection and Control. Gordon and Breach Science Publishers, New York, 1969.

17. Monitoring of Radioactive Contamination on Surfaces, International Atomic Energy Agency, Technical Report Series No. 120, Vienna, 1970, p. 4.

18. Directorate of Regulatory Standards, Measurements of Radionuclides in the Environment - Sampling and Analysis of Plutonium in Soil, Regulatory Guide 4.5, U. S. Nuclear Regulatory Commission, Washington, DC, May 1974.

19. Environmental Instrumentation Group, Instrumentation for Environmental Monitoring, LBL-1, Vol. 3 - Radiation, University of California, Lawrence Berkeley Laboratory, Berkeley, CA, 1972.

20. J. P. Corley, et a1., A Guide for Environmental Radiological Survei1lance at ERDA Installations, ERDA-77-24, U. S. Energy Research and Development Administration, Washington, DC, March 1977.

21. National Council on Radiation Protection and Measurements, Environmental Radiation Measurements, NCRP Report No. 50, NCRP, Washington, DC, 1976.

22. Directorate of Regulatory Standards, Environmental Technical Specifications for Nuclear Power Plants, Regulatory Guide 4.8, U. S. Nuclear Regulatory Commission, Washington, DC, December 1975.

23. J. H. Harley, ed., HASL Procedures Manual, HASL-300, Supplement 2, Health and Safety Laboratory, HASL 300 REV, pp. D-08-01, 02, 03, New York, NY, August 1974. 


\subsection{DECOMMISSIONING METHODS AND COSTS}

Three basic decommissioning modes are considered in detail in this study-immediate dismantlement, protective storage and layaway. The activities associated with these modes can be divided into four phases:

- Planning and Preparation activities are assumed to be carried out during the final two years of facility operation. During this period the decommissioning plan is prepared, necessary documents are submitted to regulatory agencies for review and licensing action, the decommissioning staff is assembled and trained, and equipment is designed or specified and procured. Facility shutdown activities, which are not part of decommissioning and include final operational cleanout flushes, are carried out at the end of this period.

- Decommissioning Operations are the activities carried out to implement the decommissioning plan. Decommissioning operations at a FRP start after the final operations flush. They begin with a thorough chemical decontamination of process equipment and process cell surfaces. Subsequent decommissioning activities range from removal of all radioactive contamination from the site for dismantlement to minimal cleanup and equipment deactivation for layaway. For dismantlement these activities include demolition of decontaminated buildings and restoration of the facility site.

- Interim Care activities are carried out after the basic decommissioning operations for the layaway and protective storage modes have been completed. These activities consist of continuing maintenance and surveillance, and are performed until the facility is finally decommissioned.

- Final Decommissioning activities are carried out at the end of the interim care periods following layaway and protective storage. At this time the plant is dismantled by removal of all residual radioactivity above disposition criteria levels to an approved disposal facility, and the site is restored to approximately its pre-facility condition. 
The scope of the planning and preparation activities is similar for all three decommissioning modes, although the level of effort required in some areas varies significantly between modes. Planning activities for the three modes are reviewed in Section 7.1 . The chemical decontamination procedures carried out at the beginning of each decommissioning mode and an overview of mechanical decontamination methods are presented in Section 7.2.

Decommissioning procedures for each of the three modes considered in this study are summarized in Sections 7.3 through 7.5. The procedures were developed after a careful review of presently available decommissioning techniques. These reviews included literature searches $(1)$ and consultations with personnel experienced in decommissioning of nuclear facilities. The literature search culminated in development of a computerized information retrieval system for decommissioning reference documents. This system was used extensively throughout the development of this study. The techniques selected for application to various portions of the facility are based on engineering judgment of a reasonable balance between safety and costs. It is recognized that improvements in the decommissioning plan and advances in decommissioning technology should have a favorable impact on the safety and efficiency of decommissioning.

It is anticipated that an FRP placed in layaway or protective storage following plant shutdown would eventually be dismantled as discussed in Section 3.1. The methods for deferred dismantlement are discussed in Sections 7.4 and 7.5 .

The decommissioning procedures presented are based on the key bases presented in Section 3.3 and additional assumptions concerning the condition of the facility at the time of operational shutdown. Rediation dose rates in the facility are estimated in Section 5.4. It is also assumed that no serious accidents have occurred at the facility during its operation, and that minor spills of contaminated materials inside the facility have been cleaned up as they occur, so that residual contamination from such accidents is not present at the time of decommissioning.

Estimated quantities of decommissioning wastes generated for each mode are summarized in Section 7.6. Methods for packaging and transporting the 
wastes to an offsite disposal facility are also discussed. Low level wastes are assumed to be shipped to a shallow land burial ground. Wastes contaminated with transuranic elements or large amounts of fission products are assumed to be transported to a federally operated deep geologic disposal site. All wastes originating in portions of the plant with potential for transuranic (TRU) contamination are assumed to be TRU wastes for disposal purposes.

The manpower required to carry out the procedures described for each deommissioning mode are presented in Section 7.7. Total decommissioning costs for each mode including costs for planning, actual decommissioning activities, interim care and final decommissioning operations are presented in Section 7.8.

Further details and supporting information for the material presented in this section are contained in Volume 2, Appendix E.

\subsection{PLANNING AND PREPARATION}

General decommissioning plans are submitted as part of the Final Safety Analsis Report prepared to obtain the plant production operations license. The activities required to prepare the detailed plans for decommissioning of the reference FRP are expected to take place during the final two years of facility operation. This allows decommissioning operations to begin as soon as processing operations have been terminated. The major planning activities are presented in Figure 7.1-1 along with the approximate time period over which they should take place. All of these activities are required for each decommissioning mode, although the level of effort in some areas will vary between the three modes considered in this study.

Two general types of activities are required to prepare for the decommissioning: 1) activities carried out to fulfill the regulatory requirements presented in Section 4.1 ; and 2) detailed preparations for the actual decommissioning operations. The efforts of the decommissioning staff during the first year of the planning period are devoted primarily to preparing the documentation that must be submitted to NRC to amend the facility license at plant shutdown. This documentation is expected to include a master decommissioning plan and safety analysis; a set of revised technical specifications that will govern post-shutdown and decommissioning operations; and an environmental report. 
$\frac{\text { ACTIVITY }}{\text { ASSEMBLE AND TRAIN DECOMMISSIONING STAFF }}$

PREPARE DECOMMISSIONING PLAN

PERFORM DECOMMISSIONING SAFETY ANALYSIS

PREPARE ENVIRONMENTAL REPORT

PREPARE REVISIONS TO TECHNICAL SPECIFICATIONS

PREPARE DECOMMISSIONING QA PLAN

PREPARE DECOMMISSIONING SAFEQUARDS/SECURITY PLAN

SUBMIT DOCUMENTATION TO NRC FOR LICENSE REVISION

NRC REVIEWS AND LICENSEE RESPONSE

PREPARE DETAILED DECOMMISSIONING ACTIVITY SPECIFICATIONS

DESIGN, SPECIFY AND PROCURE DECOMMISSIONING EQUIPMENT

FINAL OPERATIONAL CLEANOUT FLUSHES OF MAIN PROCESS BUILDING

FINAL SNM ACCOUNTING

OTHER PRE-SHUTDOWN ACTIVITIES

NRC ISSUES POSSESSION-ONLY LICENSE (a)

PRE-DECOMMISSIONING RADIATION SURVEYS
TIME, MONTHS

PRIOR TO PLANT SHUTDOWN

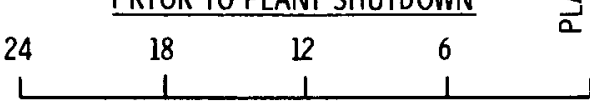

호을
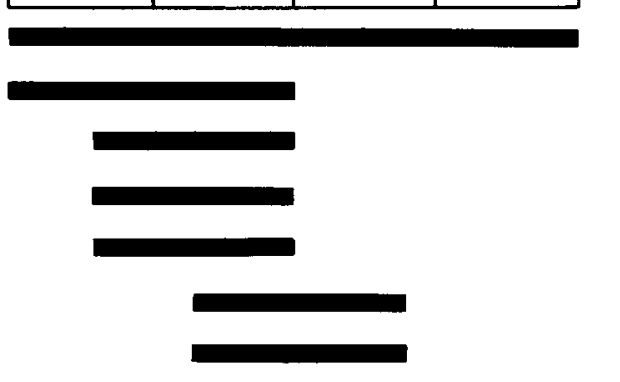

$\Delta$

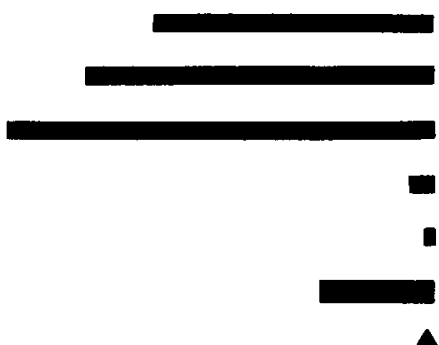

(a) A MODIFIED OPERATING LICENSE COULD BE REQUIRED FOR A PERIOD OF TIME FOLLOWING PLANT SHUTDOWN.

FIGURE 7.1-1. Approximate Schedule of Events for FRP Decommissioning Planning and Preparation Phase

\subsubsection{Master Decommissioning Plan}

The master decommissioning plan is expected to include the following:

- The decommissioning objectives for the facility and site.

- A description of the proposed decommissioning activities, including a schedule of events.

- An analysis of the significant safety issues associated with the proposed decommissioning activities.

- A review of the decommissioning Quality Assurance Plan. 
- A review of the decommissioning Safeguards and Security Plan.

- An emergency plan for responding to unplanned events during the decommissioning.

\subsubsection{Safety Analysis}

The full requirements of a decommissioning safety analysis have not yet been identified by NRC. Based on requirements for safety analysis reports required for construction permits, it is expected that the decommissioning safety analysis would contain the following:

- An estimate of the radioactive inventories in the facility when decommissioning activities begin.

- An analysis of the adequacy of existing plant safety systems to protect the public health and safety during decommissioning and the interim care period.

- A description of special safety systems and procedures required during the decommissioning or interim care periods.

- A review of the decommissioning industrial and radiological safety program.

- A review of the decommissioning training program.

\subsubsection{Quality Assurance Program}

The primary purposes of the decommissioning quality assurance (QA) program are: 1) to assure that adequate precautions are established to protect the health and safety of the public and decommissioning workers during the decommissioning operations 2) to assure that established safety precautions are followed during decommissioning activities and 3) to audit the performance of decommissioning actities. The requirements of a decommissioning QA program were outlined in Section 4.1. A more detailed review of the elements of the decommissioning $Q A$ program is presented in Volume 2, Appendix E.1. 
The QA program is divided into two phases: planning and operations. The QA program plan delineates the procedures that will be used to fulfill the QA objectives during these two phases. The emphasis of the program during the planning period is in the following areas:

- Reviews of safety aspects of detailed decommissioning activity specifications.

- Preparation of plans to perform QA audits of decommissioning activities.

- Qualification of suppliers for radioactive material shipping containers and other decommissioning equipment.

- Preparation of inspection/test procedures for subcontractors.

- Verification of the acceptability of procured equipment.

- Auditing of quality control procedures for suppliers of specialized decommissioning equipment.

The emphasis during decommissiong operations is in the following areas:

- Continuation of QA functions for procurement.

- Monitoring of decommissioning activities for compliance with the detailed working specifications.

- Reviews of changes in activity specifications for compliance with safety requirements.

- Verification that shipments of radioactive material are made in compliance with government regulations.

- Maintenance of QA files and preparation of QA reports for submission to NRC.

\subsubsection{Safeguards and Security Plan}

The decommissioning safeguards and security plan is developed to ensure that proper methods exist to protect Special Nuclear Material (SNM) and to guard against acts of sabotage during the decommissiong. Safeguards requirements were discussed in Section 4.2. It is expected that the safeguards and security procedures during the chemical decontamination phase of the decommissioning would be similar to those used during plant production operations 
At the end of chemical decontamination, it is assumed that formal SNM safeguard requirements would cease and that industrial-type security would be maintained at the facility.

\subsubsection{Environmental Report}

The decommissioning environmental report would provide NRC with the basic information necessary to assess the environmental impact of the proposed decommissioning activities. The NRC may issue an environmental impact statement for the proposed decommissioning activities or a "Negative Declaration of Environmental Impact" (see Section 4.1). For estimating decommissioning costs in this study, it has been assumed that a comprehensive environmental report is prepared for dismantlement, but that the report required for layaway and protective storage represents a modest effort. Preparation of environmental reports was discussed in Section 4.1 .

\subsubsection{Technical Specifications}

The Technical Specifications (Tech Specs) for the plant delineate allowable operating conditions for plant safety systems; administrative procedures that must be followed to assure that the safety systems are operated within these limits; and plant effluent surveillance requirements. Major modifications to the Tech Specs are required because of the change in plant conditions after shutdown. A set of revised Tech Specs would be submitted as part of the application for license modification.

\subsubsection{NRC Review}

The package of documentation to support the requested licensing modification at plant shutdown is expected to be submitted to NRC about 1 year before facility operations are terminated. During the final year of the planning period, the NRC staff will review the documentation. The decommissioning staff will be required to respond to questions from NRC concerning the documentation and may be requested to furnish additional information for use in the NRC reviews. Modifications to the decommissioning plan, environmental report and Tech Specs could be made as a result of the NRC reviews. NRC may also solicit public response to the decommissioning plan and environmental report. When the review process is completed and all safety-related 
issues have been resolved to the satisfaction of NRC, the modified license, effective at plant shutdown, would be issued.

\subsubsection{Final Preparation}

Most of the detailed physical preparations for the decommissioning activities take place during the final year of the planning period. Detailed activity specifications and working procedures for the decommissioning operation are developed. Cost estimates and detailed work schedules are prepared, and equipment is designed or specified and procured. Changes necessitated by NRC reviews of the decommissioning plan are implemented.

Personnel are added to the decommissioning staff as necessary throughout the planning period. The staff training program is developed. Training of the decommissioning workers becomes a major effort in the latter stages of the planning period and the first stages of the decommissioning period. For the dismantlement mode, it is assumed that a training facility is constructed on site. This facility is used throughout dismantlement to verify procedures and practice techniques before they are actually performed.

Some activities carried out during the planning phase are not considered part of decommissioning for cost purposes, but they have been included in Figure 7.1-1 to show the relationship between decommissioning and the final operational phases of the plant. These activities include:

- Performance of the final operational cleanout flushes after the last batch of fuel has been reprocessed. These flushes are typical of operational cleanout flushes performed periodically during plant operations. They assure that most product materials have been removed from the process and permit the final SNM accounting to be made.

- Reduction of inventories of process chemicals and removal of other materials not required for the decommissioning.

- Removal of packaged radioactive wastes produced during plant operations.

The planning period concludes with a comprehensive radiation survey of the facility and site. This survey becomes the basis for finalizing decommissioning plans. 


\subsection{DECONTAMINATION METHODS}

The decontamination methods used to remove residual radioactivity from the facility generally fall into two categories: chemical decontamination and mechanical decontamination. The sections below present a brief outline of the chemical and mechanical decontamination methods used in decommissioning the facility. Further details are presented in Appendix E.2, Volume 2.

\subsubsection{Chemical Decontamination}

A11 three decommissioning modes considered in this study begin with a thorough chemical decontamination of the main process cells and main process equipment. Chemical decontamination of the liquid waste storage facilities, waste solidification plant process cells and equipment, and the fuel storage pools is carried out at later times during the decommissioning. The primary purpose of chemical decontamination is to reduce radiation levels for the equipment removal and mechanical decontamination phases of immediate dismantlement or to prepare facilities being placed in layaway or protective storage for eventual final decommissioning operations. Chemical decontamination also further reduces the amount of radioactivity available for release in the event of an accident and allows for recovery of residual product from some areas of the facility. This section describes the chemical decontamination operations that are common to the three decommissioning modes and outlines special procedures used for some modes. The procedures oulined here are the basis for the radiation dose levels shown in the "After Chemical Decontamination" columns of Table 5.4-1.

\subsubsection{Chemical Decontamination of Main Process Cells and Equipment}

Chemical decontamination of the process cells and equipment in the main process building begins when facility shutdown activities, including final operational cleanout flushes, have been completed. Chemical decontamination generally follows procedures and techniques used during plant production operations. The plant has a central decontamination solution mixing and distribution system composed of mixing tanks, heating coils and pumps. Chemical solutions are distributed from the central system throughout the main process building and introduced into the process equipment through 
manualiy assembled, external temporary connections to existing piping. Internal recirculation is possible within most major process vessels and piping, and air sparging or other agitation is provided in most tanks. The flow of chemicals during a flush is generally from equipment with low contamination levels toward equipment with higher contamination levels.

Decontamination of process cell walls and external surfaces of equipment is accomplished first by spraying the cell with a decontaminating mist through nozzles at 13.6 atmospheres (200 psi) and $1.9 \mathrm{l} / \mathrm{min}(0.5 \mathrm{gpm})$. This step is typically followed by spraying with rotating high pressure spray nozzles lowered into the cell. These spray systems are part of the original installation in the facility.

Ends of pipes and other traps where radioactive materials can accumulate are identified during the planning phase by studying blueprints, process modifications and plant operating records. The procedures developed assure that these areas receive appropriate decontamination.

The progress of the equipment internal flushes is monitored in two ways. Before chemical decontamination begins, shielded directional gamma radiation detectors are installed at strategic locations in each cell. These assist in monitoring the flushing and in identifying hot spots or areas that resist chemical decontamination. Radiation spectrographic information from these detectors helps identify the radionuclides that remain after a flush. The succeeding flush is then tailored for improved removal of these radionuclides. In addition, the decontaminating solutions are sampled from existing sample points at scheduled intervals and analyzed for dissolved contaminants. A particular flushing sequence is terminated when these tests indicate that it has achieved its maximum effectiveness. Areas that might contain significant amounts of plutonium are carefully monitored to ensure that the plutonium in the flush solution does not exceed the normal operating maximum concentrations or quantities. Solutions approaching these limits are removed from the area and fresh solutions are introduced. Solutions with significant plutonium are treated as product and processed through the plutonium processing system and shipped offsite. 
A variety of flush chemicals and sequences of flushes has been proved effective in removing contamination from equipment in reprocessing plants. A representative series of flushes is outlined in Volume 2, Appendix E.2. Flush solutions that might be used include concentrated nitric acid, $3 \%$ hydrofluoric acid-20\% nitric acid, $20 \%$ sodium hydroxide- $2 \%$ tartaric acid and special solutions for removing particular chemical species or deposits. Basic flushes may be repeated as necessary in some areas. After internal chemical decontamination, the process systems are flushed with water and drained.

Before flushes external to the process equipment are initiated, mist eliminators are installed upstream of the process cell exhaust filters. These mist eliminators protect the filters from damage by moisture and chemicals used in the flushing procedures.

A typical series of flushes that could be used external to the process equipment is presented in Volume 2, Appendix E.2. Chemicals used are typical of those used in internal equipment flushes. Progress of the flushes external to the process equipment is monitored as were the internal flushes, with the temporary directional gamma detectors and by analyzing the solutions sampled from the cell sumps. A particular flush is again terminated when these factors indicate that it is approaching its maximum effectiveness.

The effectiveness of chemical decontamination depends on several variables including the type of chemical used, the physical and chemical characteristics of the contamination, the amount of time the chemical solution remains in contact with the contaminated surface and the availability of sprays or solution agitating systems. In decommissioning operations, chemical flushes may be designed for maximum removal of residual contamination with only moderate regard for corrosion of equipment. It is assumed for this study that chemical decontamination will typically result in a decontamination factor of 1000 on the internal surfaces of process equipment. This value is felt to be representative because of the effectiveness of the chemicals used in combination with intalled equipment such as internal sprayers, mixers, air spargers or agitators.

A chemical decontamination factor of 100 is used as typical for external surfaces of stainless steel equipment and stainless steel cell liners. This 
value is felt to be representative because the spray systems and chemicals used for these procedures are generally effective at removing contaminants from stainless steel. Shadowing of some equipment by other vessels and piping generally results in some "hot spots" that are not thoroughly decontaminated. Hot spots that would contribute significantly to occupational exposure during decommissioning are identified during radiation surveys. These spots are further decontaminated by contact methods or covered with temporary shielding.

A chemical decontamination factor of 2 is used for the concrete walls of process cells. Although the concrete surfaces in the cells were initially coated with an acid-resistant paint, it is anticipated that this coating would deteriorate over the lifetime of the plant, exposing much of the porous concrete to radioactive contamination. Spills of radioactive process solutions can be expected to penetrate the surface layers of the concrete in these circumstances, so that chemical decontamination has minimal effectiveness.

About 400,000 liters of waste solution are estimated to be transferred to the waste storage tank farm from the waste concentrators as a result of chemical decontamination operations in the main process building. Aluminum nitrate $\left[\mathrm{Al}\left(\mathrm{NO}_{3}\right)_{3}\right]$ is added to the solutions containing hydrofluoric acid before they are concentrated and transferred to the waste tanks. Aluminum acts as a complexing agent for the corrosive fluoride ions, thereby reducing corrosion in the equipment.

\subsubsection{Chemical Decontamination of the Liquid Waste Storage System}

Chemical decontamination of the liquid waste storage areas begins after the waste solutions in the liquid waste storage tanks have been processed through the waste solidification plant. Procedures for chemical decontamination of the waste tank equipment gallery and the HLLW and ILLW storage tanks are outlined below.

- Waste Tank Equipment Gallery (WTEG)

Chemical decontamination of the offgas treatment areas and diverter cell in the WTEG follows procedures similar to those described above for the process cells in the main process building. Equipment is flushed internally and cell walls and external surfaces of equipment are decontaminated using installed mist spray nozzles and rotating high pressure sprayers. 
A chemical decontamination factor of 1000 is anticipated inside process equipment. Since the areas containing the off-gas treatment equipment have concrete walls, chemical decontamination is expected to result in only modest decreases of radiation levels in these areas. The diverter cell is completely lined with stainless steel. Chemical decontamination is expected to reduce the residual radioactivity levels on the cell walls and external surfaces of process equipment by a factor of 100 .

- Intermediate-Level Liquid Waste (ILLW) Tank

The ILLW tank is chemically decontaminated by four successive flushes with 38,000 l each of concentrated nitric acid. Each flush is pumped out with the installed empty-out jets before the next flush is introduced. These flushes dilute the heel in the tank and dissolve residual radioactivity deposited on the tank bottom. The heel from the final flush is removed by installation of a long-shaft pump through the installed tank riser. These procedures are expected to reduce radiation levels in the tank by a factor of 1000 .

- High-Level Liquid Waste (HLLW) Tanks

Chemical decontamination procedures for the HLLW tanks differ somewhat for each of the three decommissiong modes considered in this study. The three HLLW tanks are decontaminated by four successive flushes of $38,000 \mathrm{l}$ each of concentrated nitric acid (as was the ILLW tank) to dilute the tank heels and dissolve deposits on the tank bottom. For layaway, the nitric acid concentration of the final flush is adjusted so that the residual solution in the tanks that is not removed by the final pumpdown is about 1 molar nitric acid. This solution remains in the tanks during the interim care period. The 1 molar nitric acid concentration is selected because it minimizes the corrosion of the stainless steel in the tanks while maintaining sufficiently high acidity to minimize precipitation of residual fission products and actinides from the solution. The four nitric acid flushes are estimated to reduce residual radiation levels in the HLLW tanks by about a factor of 150 . (See Volume 2, Appendix B.) 
For the protective storage mode, the residual solution in the tanks from the final flush is removed by penetrating the tank top and installing a submersible pump. (See Section 7.4.) After the residual solution (heel) has been removed, the tank is flushed with about 10,000 \& of water and pumped dry again. An inorganic absorbent material is then introduced into the tank to absorb any excess liquid that remains. The combination of the four nitric acid flushes and removal of the heel from the HLLW tanks is estimated to reduce residual radiation levels in the tanks by about a factor of 300 . (See Volume 2, Appendix B.)

For dismantlement, the final two heel flushes of the HLLW tanks are introduced through high pressure, low volume spray nozzles installed through the tank tops. (See Section 7.3.) These sprays provide chemical decontamination of the tank walls and internals as well as diluting the heel and dissolving deposits on the tank bottom. Submersible pumps are also installed to remove the residual solution from the tanks before actual dismantlement activities begin. After the heel is pumped out, a 10,000 \& water rinse is introduced through the spray nozzles. This solution is also removed with the submersible pump. The combination of the heel flushes, sprays and removal of the residual solution from the tanks is expected to reduce residual radiation levels in the tanks by a factor of about 2500 (see Volume 2, Appendix B).

Chemical decontamination of the liquid waste storage areas is estimated to produce about 300,000 liters of solution that must be processed through the waste solidification plant. This waste volume estimate assumes that heel flush solutions from the ILLW tank are reused in the HLLW tanks and that some of the final flush solutions in the HLLW tanks are reused as the initial flush solutions in other tanks.

\subsubsection{Deionizing, Draining and Chemically Decontaminating the Fuel Storage Pools}

Decommissioning activities in the fuel receiving and storage station (FRSS) begin after all radioactive liquid wastes have been processed through the waste solidification plant and all canisters of solidified high-level waste have been shipped offsite. The fuel storage pool and cask unloading pool water is filtered and deionized using installed equipment (upgraded as 
lecessary) to radioactivity levels permitted for release to the environment by 10 CFR 20 consistent with the principle of ALARA. ${ }^{(2)}$ The pool water is vaporized with the nitric acid fractionator overhead vaporizer and released through the 100-meter stack or released to the river through the onsite water reservior.

As the pools are drained, the walls and fuel storage racks are sprayed with high pressure water or steam to remove residual radioactive contamination. Radioactive particulates that may have settled out on the pool floor are removed with any underwater vacuum cleaner when about $2 \mathrm{~m}$ of water remain in the pool. Areas of localized contamination are identified by a radiation survey and are cleaned using spot decontamination techniques. For layaway and protective storage, the pool walls, floor and equipment are codted with at least two layers of paint to fix residual contamination. Radiation levels in the pools from residual contamination are expected to be low.

\subsubsection{Chemical Decontamination of the Waste Solidification Plant (WSP)}

Final chemical decontamination of the process cells and pipe and ventilation trenches in the WSP takes place after the solutions from chemical decontamination of the liquid waste storage system have been solidified. Much of the WSP process equipment is flushed internally when the tank farm decontamination solutions are processed through it. Some additional internal flushes are carried out using procedures and chemicals similar to those described previously for the process equipment in the main process building. The WSP process cell walls and external surfaces of process equipment are decontami-

ted using installed high pressure, low volume spray nozzles and rotating .gh pressure sprayers. Since cell walls and equipment are stainiess steel, external decontamination is expected to reduce residual contamination levels by a factor of 100 .

Pipe trenches and ventilation trenches are chemically decontaminated using a traveling high pressure sprayer. Ventilation filters are protected by installation of mist eliminators where necessary. All trenches are lined with stainless steel, so decontamination factors of 100 are anticipated. 
Al1 chemical decontamination solutions are collected and processed through the calciner and in-can-melter. Processing of these final solutions may result in localized radioactive contamination on equipment or cell surfaces. This contamination is identified by radiation surveys and removed using spot decontamination techniques or covered with temporary shielding if it would contribute significantly to radiation dose levels during subsequent decommissioning operations.

\subsubsection{Chemical Decontamination of Other Areas}

Chemical decontamination is also used in most other radioactive areas of the facility to reduce radiation levels for subsequent decommissioning operations or to remove loose or "smearable" contamination. A variety of techniques is used, depending on the type and extent of the contamination. Many of these techniques are used routinely during facility production operations. Small areas with relatively loose contamination may be cleaned using simple "janitorial" techniques such as sweeping or swabbing. Sponges soaked in decontamination solution can be used to remove radioactive contamination from metal or painted concrete surfaces. Portable high pressure decontamination solution sprayers can be used either remotely or by contact to remove contamination from larger areas or to decontaminate "hot spots" that remain after other chemical decontamination operations. These procedures are discussed in more detail in Volume 2, Appendix E.2. The portions of the facility where these techniques are expected to be applied are pointed out in the following sections and in Volume 2, Appendix E.3 through E.5.

\subsubsection{Mechanical Decontamination}

When chemical decontamination and surface cleaning procedures cannot reduce surface contamination to unrestricted use levels, the surface itself must be removed. Several criteria must be considered when selecting a decontamination method for a particular location. The method should facilitate control of airborne contamination, minimize the spread of contamination to clean areas, minimize the potential for personnel exposure, and permit control of the size and weight of removed materials to facilitate packaging and shipping for disposal. 
A number of surface scarfing (removal) techniques were employed in this study, including: blasting, ${ }^{(3)}$ rock splitting, ${ }^{(4)}$ and jackhammering. The use of water cannons ${ }^{(4)}$ could prove to be an effective surface removal technique, however they are still in the development stage and an adequate assessment of their use could not be made. The three methods used were chosen based on comparison of the advantages and disadvantages of available surface removal techniques. A more detailed discussion of scarfing techniques is presented in Volume 2, Appendix E.2. Detailed descriptions of equipment used in surface removal operations are presented in Volume 2, Appendix E.3.6.

\subsection{DISMANTLEMENT MODE}

The procedures presented here for dismantlement of the reference Fuel Reprocessing Plant (FRP) are expected to remove all potentially hazardous amounts of radioactive materials and chemically toxic substances from the site. For this study, the site is assumed to be radioactively contaminated at levels up to those for unrestricted use and returned to approximately its pre-facility condition after dismantlement is completed. Nonradioactive portions of the buildings that have been decontaminated are demolished using conventional demolition techniques. Concrete rubble is used partially as backfill and native vegetation is planted on the site. Portions of the facility, such as office buildings and warehouses that were not used for radioactive operations, are assumed to have a salvage value equal to or greater than demolition costs, and for this study were assumed to be left intact on the site. When dismantlement activities are completed the facility owner will apply to the Nuclear Regulatory Commission for termination of the nuclear facility license. It is assumed that no restrictions will be imposed on subsequent non-nuclear use of the site.

\subsubsection{Overview of Dismantlement Activities}

The facility is considered to be divided into five major sections in this dismantlement plan. These facility sections are:

- main process building

- liquid waste storage area

- waste solidification plant (WSP) 
- fuel receiving and storage station (FRSS)

- auxiliary facilities (filter building, stack, and laboratories)

The dismantlement operations in each section of the facility are divided into the following five major stages:

- planning and preparation

- chemical decontamination

- removal of contaminated equipment

- mechanical decontamination of structures

- structure demolition and site restoration

Planning and preparation activities (as described in Section 7.1) are carried out concurrently with the final 2 years of plant operation. Chemical decontamination of the facility is performed first to reduce radiation levels. This step is common to all decommissioning modes and was discussed in Section 7.2 .

A sequence of major activities for dismantlement of the facility is shown is Figure 7.3-1. After completion of chemical decontamination of the main process building, all equipment is removed and the building is mechanically decontaminated. Next, the liquid waste storage facility is decontaminated and demolished, followed by decommissioning of the waste solidification plant. The fuel receiving and storage station (FRSS, which serves as a temporary storage area for high-level solidified waste canisters) is then decommissioned; and finally the auxiliary facilities are decontaminated and dismantled. After surveys to ensure that all contaminated materials have been removed from the site to levels that are allowable for unrestricted release, the structures are demolished and the site restored to approximately its pre-facility condition.

An outline of the post-shutdown activities employed to dismantle the five sections of the plant is presented in Table 7.3-1. Portions of these activities in various sections of the facility may overlap and proceed concurrently. The activities in Table 7.3-1 are summarized below. Amplifying details are presented in Volume 2, Appendix E.3. 


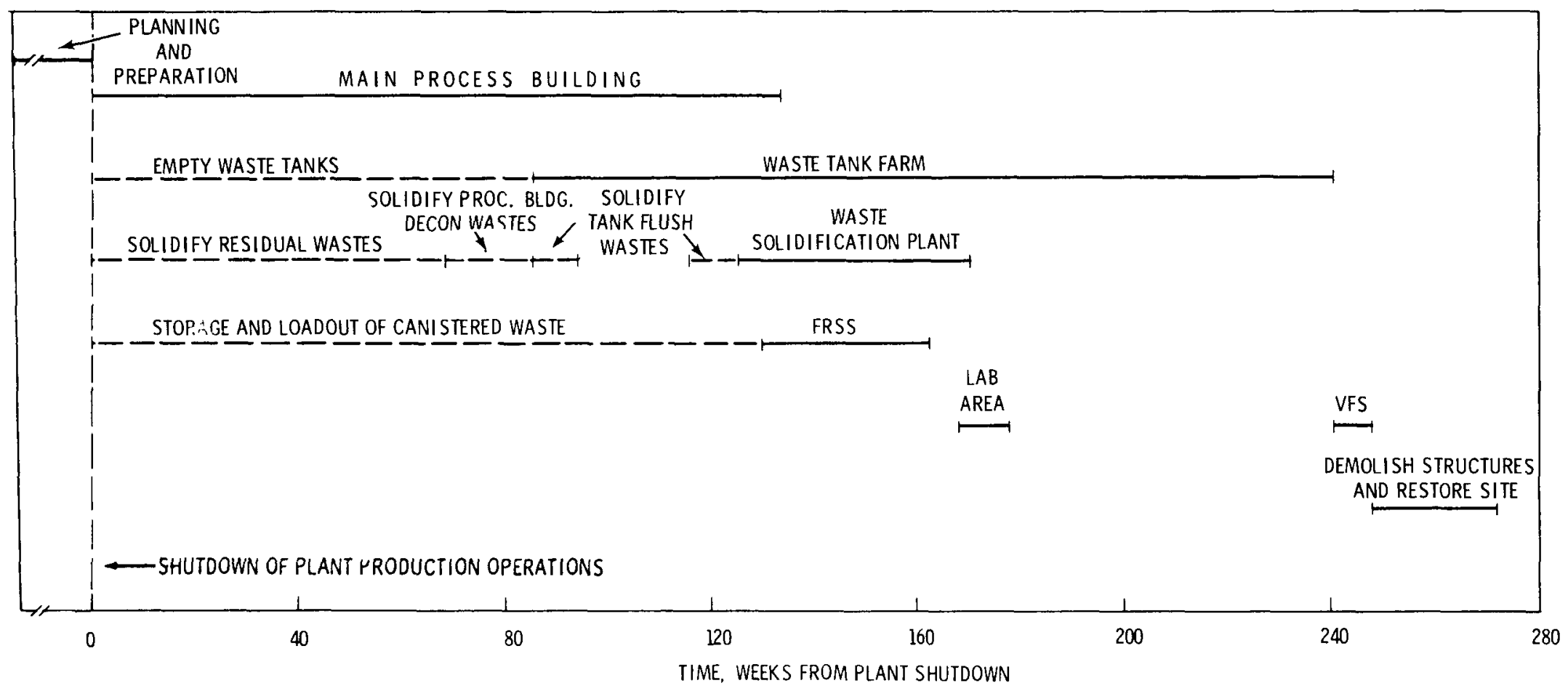

FIGURE 7.3-1. Sequence of Major Activities for Dismantlement of the Reference Fuel Reprocessing Plant 
0

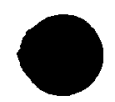


TABLE 7 3-1. Outline of Dismantlement Activities(a)

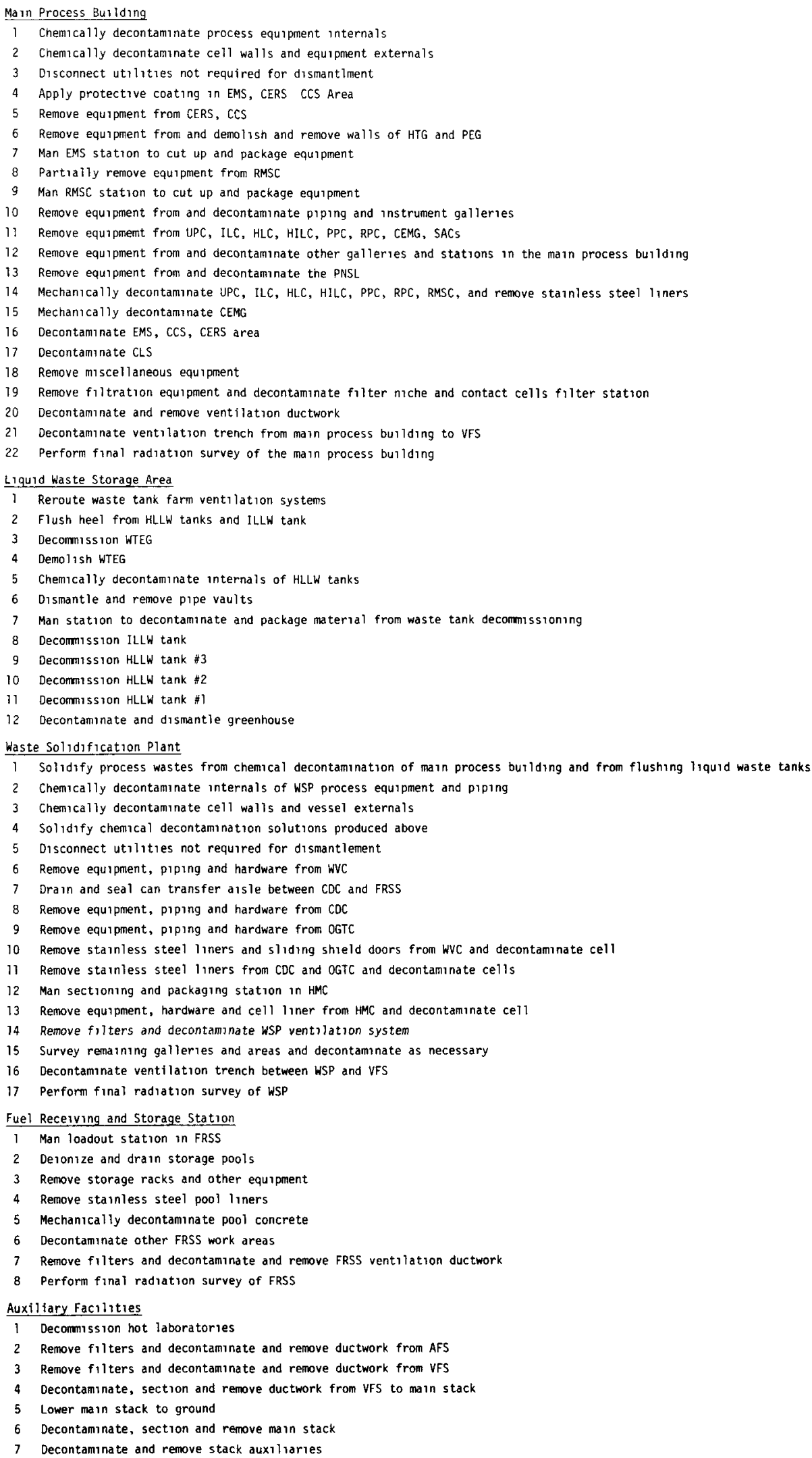


$x+1$

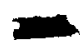

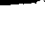




\subsubsection{Dismantlement of the Main Process Building}

Activities during the dismantlement of the main process building consist of all of the tasks necessary to remove, package, and ship all hazardous materials and equipment from the facility. All dismantlement work is accomplished in accordance with the dismantlement plan, task specifications, detailed working procedures, and health and safety control programs developed during the planning and preparation phase.

\subsubsection{Removal of Equipment from the Main Process Building}

Following internal chemical decontamination of process equipment and chemical decontamination of cell walls and vessel externals, all utilities in the main process building not needed for dismantlement are disconnected. Equipment is removed from the process areas, packaged, and shipped offsite. Removal of equipment permits subsequent mechanical decontamination of the process building structures. Slightly contaminated equipment could be salvaged by using an electropolishing unit to decontaminate it thoroughiy. Such a unit is discussed in Appendix E.3.6, Volume 2.

- Equipment Maintenance Station (EMS), Contact Equipment Removal Station (CERS), Cold Chemical Station (CCS), Head Tank/Pulser Equipment Gallery (HTG/PEG), and Top and Lower Piping and Instrument Galleries (TPIG/LPIG)

In preparation for equipment removal from the process cells of the main process building, a large working area is first prepared in the CERS - CCS area. This area is then used to gain access to the process cells below. A strippable plastic coating is applied to the floors and walls to facilitate decontamination during equipment removal operations from the process cells. Equipment is removed from the LERS, CCS, and HTG/PEG, and the walls of the HTG/PEG are removed. This provides access to the areas above the pulse columns in the process cells.

The CERS contains portions of the HA centrifugal contactor and the $1 B X$ electropulse column that protrude through the process cell ceilings. This equipment is installed in removable shielding plugs and is removed using routine plant maintenance procedures. Blank plugs are installed in the holes 
left by removal of this equipment. Because no significant radioactive contamination is anticipated in the CCS, removal of equipment from that area is done using conventional contact techniques.

A section of the walls of the HTG/PEG are removed to provide access to the equipment in these galleries. The equipment is removed, cut up in place as necessary, packaged and shipped for disposal. The gallery walls are then demolished using explosives. The concrete rubble is packaged and shipped for disposal. Al1 nonventilation penetrations between the gallery areas and the process cells are sealed as they are opened. Ventilation penetrations remain open. Some rerouting of ventilation ductwork is anticipated. Emergency electric power cables that run through the galleries are rerouted around the gallery area.

The equipment in the TPIG, LPIG and filter piping and instrument gallery (FPIG) is removed. All nonventilation penetrations between these galleries and the process cells are sealed to minimize the spread of contamination during operations in the cells.

- Process Cells

The radiation survey at the end of the chemical decontamination phase provides the basis for actual working levels to be encountered in each cell during equipment removal. Direct human contact with process equipment is planned in the uranium product cell, the intermediate level cell, the plutonium nitrate storage and load-out area, and the crane and equipment maintenance gallery. Portable shielding is used as necessary to accommodate contact operation in these areas.

The radiation levels anticipated in the high level cell preclude practical contact activities during removal of the equipment and mechanical decontamination of the concrete. To conduct these operations in the HLC, a shielded working cage is built that can be lowered into the cell using the crane in the equipment maintenance station above. Conceptual specifications for the cage are given in Volume 2, Appendix E.3.6. 
A shielded working platform that can be placed over the existing hatch opening when the cage is in position in the cell is also constructed. This platform reduces the radiation out of the open hatch, allows personnel to work in the vicinity of the hatch with relatively low radiation exposure, and provides some separation of the ventilation systems inside and outside the process cell. Conceptual specifications for the platform are given in Appendix E.3.6.

Although radiation levels in the high-intermediate level cell may allow contact operations, the shielded cage is used in this cell to limit exposure to the dismantlement crew.

Radiation levels expected in the plutonium product cell (PPC) preclude the use of contact operations without shielding during removal of contaminated equipment. Because the EMS crane does not serve the PPC, the shielded cage cannot be used. Movable leaded rubber sheets are placed on the walls of the cell to reduce radiation to levels that permit contact work to be done in the cell.

The remote process cell contains sufficiently high levels of radiation to prevent equipment removal by contact methods. This cell contains manipulators, viewing windows, cranes, and other maintenance equipment necessary to carry out removal operations remotely. In the remote maintenance and scrap cell (RMSC) the existing remote maintenance capabilities are used to perform equipment removal. Because the RMSC is used during equipment removal operations in other cells, only equipment not needed for the dismantlement operations are removed initially.

Most of the equipment and piping in the process cells is constructed of 304L stainless stee1. A number of techniques can be used to perform the cutting operations including arc sawing, plasma torch cutting, and the use of shaped explosives, as described in Appendix E.3.6 of Volume 2. In this study a plasma torch was believed to offer more advantages and was assumed for use in cutting metal materials in the process cells. A portable filtered ventilation enclosure (see Appendix E.3.6, Volume 2) can be used if necessary to reduce the amounts of contaminants made airborne by the cutting operations. 
Removal of large pieces of equipment that are accessible directly from a cell hatch is accomplished as follows. The equipment is cut loose, and lifted out using the 55-MT (60 ton) equipment maintenance station crane that spans the area above the process cells. Vertical clearance from the EMS crane hook to the contact equipment removal station (CERS) floor is about 6 meters $(20 \mathrm{ft}$ ). A specially prepared area of the CERS with temporary movable shielding and cutting equipment is normally used to section equipment that has been removed from the cell. Sectioning is done as required for materials that are too large for the waste shipping containers. Highly radioactive materials are moved to the RMSC where they are sectioned remotely, and loaded into containers for disposal offsite.

After removal from the cell, the contaminated equipment is sealed in another layer of plastic wrapping and loaded into a shipping container in an area of the contact equipment removal station near the cell hatch. The container is moved to the cask loading station (in a transfer cask if shielding is required) and placed in a cargo container for transport to a disposal site.

Many major pieces of equipment in the cells cannot be reached directly with the 55-MT EMS crane through the cell hatches. Removal of this equipment requires a method for lowering it to the cell floor where it can be dragged to the area beneath the hatch and lifted out. In the process cells where contact methods are used, a lifting hook is installed in the ceiling above the equipment from which the equipment is lowered using a block and tackle. Where remote methods must be used, a $2.5-\mathrm{cm}\left(1-\mathrm{in}_{\text {. }}\right)$ hole is track-drilled from the CERS down through the ceiling above the vessel. A cable attached to a 4.5-MT (5-ton) mobile crane is passed through the hole and attached to the equipment by operators in the shielded cage. The equipment is then detached and lowered to the floor.

The crane and equipment maintenance gallery will have been used routinely for contact operations so that the expected radiation levels will be moderately low. The floor is protected with a disposable covering during equipment removal operations in the remote cells. Equipment in this gallery that is not needed during equipment removal from the remote cells is removed prior to the commencement of operations. The remainder is packaged and removed afterward 
Detailed descriptions of the equipment removal operations in the process cells are presented in Volume 2 Appendix E.3.1.

- Sample and Analytical Cells (SACs)

Some of the equipment in the eight sample and analytical cells will have relatively high contamination levels. This equipment is removed remotely using the installed manipulators and inter-cell conveyor system. Following equipment removal, the structural surfaces of each cell are chemically decontaminated using a portable sprayer and the installed manipulators. The cell drains must be rerouted to a temporary collection point, as the vessel they normaliy drain to will have been removed previously. Mechanical decontamination of the structural surfaces of the cells is carried out by contact methods using hand tools. Hand drilling and rock-splitting techniques are used and the concrete rubble is removed manually through the access doors. The two plutonium glove boxes associated with the sample and analytical cells are removed using the procedures in Appendix E.3.1.6, Volume 2. The stainless steel floor liner is sectioned and removed. Any contamination on the underlying concrete is removed as necessary.

- Plutonium Nitrate Storage and Loadout Area (P:ISL)

Equipment and glove boxes from the plutonium nitrate storage and loadout area are removed with a portable crane and fork lifts. A nonflammable coating is applied to the floor and walls of the plutonium nitrate operating gallery (PNOG) and to the interior surfaces of the gloveboxes to help reduce the spread of contaminants. The slab-shaped storage tanks are sectioned and packaged in the cells for geologic disposal. Neutron shields are sectioned, spray coated, and packaged for surface burial. All equipment from the plutonium nitrate cells (PNCS) is removed through openings cut in the north wall of the cells.

A more detailed description of equipment removal operations is presented in Appendix E.3.1, Volume 2.

- Other Galleries, Stations, Service Areas

Other galleries, stations and areas in the main process building not specifically covered in the preceding sections or the appendices are expected 
to contain little or no radioactive contamination. The radiation survey identifies contaminated equipment which is detached and removed by conventional contact methods.

Throughout the period of time that equipment removal operations are being conducted in the main process building, the ventilation flow patterns must be monitored and maintained to prevent the spread of contamination. For the most part, the existing ventilation pathways are used, but it will be necessary at times to seal some ventilation openings and/or to by-pass and modify the existing system to assure the desired performance of the ventilation and filtration system.

\subsubsection{Mechanical Decontamination of Main Process Building}

The next phase is mechanical decontamination of the process area structures. With a few exceptions (remote maintenance and scrap cell walls, filter niche, process cell floor liners) the walls, floors and ceilings in the main process building that are exposed to potential contamination are concrete originally coated with an acid-resistant paint. Over the lifetime of the plant it is expected that much of this coating will deteriorate and allow spills of contaminated solutions to be absorbed into the porous concrete. Chemical decontamination is relatively ineffective under these conditions. To ensure that all potentially hazardous amounts of radioactivity are removed from the facility, 5 to $15 \mathrm{~cm}$ ( 2 to $5 \mathrm{in.}$ ) are removed (scarfed) beneath the surface of the contaminated concrete. Before scarfing is initiated, modifications (such as installation of additional roughing filters) are made to the ventilation system to accommodate the potentially high dust loading.

Three methods of concrete scarfing were employed in this study: explosives, ${ }^{(3)}$ rock splitting, ${ }^{(4)}$ and jackhammering. Flame spalling and the use of water cannons, ${ }^{(4)}$ al though not used in this study, could also prove to be effective scarfing techniques.

Large areas, such as the concrete cell walls, are scarfed with explosives back to the first layer of reinforcing bar. Explosives are presently the most economical and effective way of scarfing large surfaces. (3) A detailed procedure for mechanical decontamination of concrete with explosives is given in Appendix E.2-2, Volume 2. 
In areas where contamination is not as widespread, or where blasting is not feasible, a drilling and modified rock-splitting technique is used to remove the contaminated concrete surfaces. (4) An air-operated track dri11 with a vacuum pickup or water injection system is used to dri11 holes $10 \mathrm{~cm}$ (4 in.) deep on $10-\mathrm{cm}$ centers in the concrete surfaces. Modified rock splitters positioned in these holes can scarf approximately $2.5 \mathrm{~cm}$ ( 1 in.) in depth. A description of these rock splitters is presented in Appendix E.3.6, Volume 2. For small areas of contamination, a pneumatic jackhammer is used to chip away the contaminated concrete. The concrete rubble is placed in shipping containers in the process cell being decontaminated and disposed of using normal procedures for contaminated materials.

- Uranium Product Cell (UPC), Intermediate Level Cel1 (ILC), High Level Cel1 (HLC), High-Intermediate Level Cell (HILC), and Remote Process Cel1 (RPC)

Although scarfing of the concrete in the process cells only slightly degrades the structural integrity of the main process building, the schedule is arranged so that the time after scarfing and before final demolition of the structure is minimized. Throughout the scarfing operation, the stainless steel floor liner in each process cell remains in place to minimize contamination of the concrete cell floor.

The surfaces of the south, east, and west walls of the UPC, ILC, HLC, and the HILC, and the north, east, and west walls of the RPC are all accessible by drilling from above the cell. Track drills are used to drill vertical holes in these walls parallel to and about $12 \mathrm{~cm}$ ( $5 \mathrm{in}$.) from the wall surface (just outside the reinforcing steel) and approximately $45 \mathrm{~cm}$ (18 in.) apart. These holes are drilled down to the bottom of the cell wall. This drilling is done using the CERS floor above the cells as a drilling platform. Explosives are then inserted into the holes and used to scarf the surfaces of these walls. The concrete surfaces are removed in 2-meter (6 ft) high sections proceeding from the top down the walls. The area to be blasted is covered with blasting mats to limit the spread of debris. A water spray system is turned on before and during blasting operations to reduce the spread of dust. 
The first three walls in each cell are scarfed in the same campaign. rubble is loaded into a waste container using a front-end loader with a shielded cab (see Appendix E.3.6, Volume 2 for conceptual specifications). Scarfed areas are covered with a protective coating of plastic or canvas to minimize recontamination during subsequent blasts.

After the first three walls have been scarfed in each cell, the ceiling is scarfed using drilling and modified rock-splitting techniques. In the cells where direct personnel contact is not practical, holes are drilled on $10 \mathrm{~cm}$ (4 in.) centers down through the ceiling from the floor of the contact equipment removal station using track drills, then sealed until they are ready to be used. A modified rock-splitter is inserted into the holes from above to remove the outer $2.5 \mathrm{~cm}$ ( $1 \mathrm{in}$.) of concrete from the cell ceiling. Most of the scarfed concrete rubble is caught in a basket positioned just below the ceiling. The rubble is lowered to the floor in the basket and loaded into waste containers with the shielded front-end loader. Where contact operations are possible, track drills are used from inside the cell to bore 10-cm-deep holes up into the ceiling on $10-\mathrm{cm}$ centers. A rock-splitter mounted on a horizontally extended platform is used to scarf the contaminated concrete in 10-cm-square sections. Rubble is again caught in a basket.

The remaining wall in each cell is not accessible by drilling from above the cell. This wall is decontaminated with explosives by drilling horizontal holes $12 \mathrm{~cm}$ ( $5 \mathrm{in}$.) deep in the concrete on $30-\mathrm{cm}(1-\mathrm{ft})$ centers. Explosives are loaded into these holes, the holes are sealed, and the wall is scarfed in sections as before.

Radiation levels in most of the process cells should be reduced sufficiently to allow contact work for the final scarfing operations. In cells where contact work is 1 imited by high radiation levels, a track system is installed so that the drilling can be carried out remotely. Using this technique requires that personnel work in the cell only when installing the track system and when loading the rubble.

The stainless steel liners on the process cell floors are removed using a plasma torch. The liners are sectioned in place into pieces that fit into a $1.2 \mathrm{~m}$ wide by $2.5 \mathrm{~m}$ long $(4 \mathrm{ft}$ by $8 \mathrm{ft}$ ) shipping container. The liners are 
removed by cutting them free from their anchor bolts with a plasma torch, and mechanically prying them from the concrete. After removal of the stainless steel liners, contaminated areas in the underlying concrete are mechanically decontaminated as necessary.

A radiation survey is performed to ensure that essentially all contamination has been removed from each cel1. When necessary, final removal of contaminated dust on scarfed concrete surfaces is done by cleaning with a special vacuum cleaner. This completes mechanical decontamination work in these cells.

\section{- Plutonium Product Cell (PPC)}

The walls in the plutonium product cell are tested to determine if the use of explosives for decontamination is acceptable. A fixing agent such as water-emulsified chlorinated rubber paint is first applied to the concrete walls. Scarfing proceeds as in the other cells, except that the scarfed concrete surfaces are painted immediately to prevent recontamination.

If mechanical decontamination by blasting is not possible, drilling and rock-splitting is employed using the procedure described for other cells above. A fixing agent is applied to the surface before drilling and after scarfing to reduce the spread of contamination. The cell liner in the plutonium product cell is removed and sectioned using the procedure contained in Appendix E.3.1.4, Volume 2 for the plutonium nitrate cel1.

\section{- Remote Maintenance and Scrap Cel1}

Final equipment removal and mechanical decontamination of the RMSC takes place only after it is no longer needed for dismantling and decontaminating equipment remotely. The cell ceiling is mechanically decontaminated as necessary using modified rock-splitting techniques. The stainless steel liner on the walls and floor of the cell is removed by cutting it free from its anchors and cutting it in sections with the plasma torch, then prying it loose from the concrete. After removal of the liner, the underlying concrete is mechanically decontaminated as necessary. 
Equipment Maintenance Station (EMS), Contact Equipment Removal Station (CERS), and Cold Chemical Station (CCS)

The EMS-CERS-CCS area is the activity center for most dismantlement operations in the process building. The strippable plastic coating applied to the walls and floors before equipment removal aids in final decontamination of the walls and floor. Working areas are routinely protected with disposable coverings. Contamination spills, etc., are removed as they occur. Despite precautions, minor amounts of contamination are expected to remain after mechanical decontamination operations in the process cells have been completed. These areas are identified during a comprehensive radiation survey and removed using spot decontamination techniques. Any decommissioning equipment in the area that is not required for further operations is packaged for disposal. Equipment required for decommissioning other portions of the facility is decontaminated if necessary and stored in the cask loading station until needed.

- Ventilation Ductwork

Except for some minor operations in the cask loading station, the ventilation system is the last portion of the main process building to be decontaminated. Most of the contamination requiring removal is located in the process cell exhaust duct system. Other duct systems are surveyed and decontaminated as necessary. Noncontaminated ductwork may be removed for salvage or left in place for removal during building demolition. Throughout decontamination of the ventilation systems, it is necessary to provide temporary ventilation flow pathways to provide confinement of contamination. Ventilation filters are replaced during these operations if they produce significant personnel radiation exposure. The filters are permanently removed when a 11 areas upstream from the filter have been decontaminated.

- Main Process Building Ventilation System

The filter niche, the contact cells filter housing and the plutonium product cell filter housing are the portions of the main process building ventilation system that are expected to require the greatest decontamination effort. These parts of the facility and the ductwork from the cells to the 
filter housings are stainless steel (or stainless steel lined). They are chemically decontaminated as necessary to reduce personnel exposure. It will be necessary to construct temporary supply and collection facilities for the decontamination solutions. The ductwork from the cells to the contact cells filter housing is sectioned for removal and packaged for shipment. The ductwork associated with the PPC filter housing is filled with foam and sectioned with a power hacksaw. If it is necessary to remove stainless steel liners from the PPC filter housing, they are sectioned with a plasma torch using the steps outlined in Appendix E.3.1.4, Volume 2, for the PNSL cell 1iners. The liners in the contact cells filter housing are sectioned with a plasma torch and packaged for shipment. Any contaminated concrete in these areas is removed by drilling and rock splitting.

The height $(1.5 \mathrm{~m})$ and width $(8 \mathrm{~m})$ of the filter niche should provide tight but adequate working space for personnel. The filter niche will have been chemically decontaminated at the end of chemical decontamination of the main process building, but will probably require additional chemical cleaning before mechanical decontamination operations can begin. Access to the niche is gained by removing concrete shield plugs from the floor of the lower viewing and operating station. Additional penetrations are made by jackhammering through the high density concrete ceiling. The equipment maintenance station crane is used to lower portable equipment into the lower viewing and operating station from the cask loading station and to lift out the shipping containers full of waste.

A detailed sequence of events for chemical decontamination, equipment removal and mechanical decontamination of the filter niche is presented in Appendix E.3.2, Volume 2.

Cask Loading Station (CLS)

Contamination in the cask loading station is expected to be low-level and confined to small areas. The portable cask decontamination pan, and the scrap container lifting rod are expected to be radioactively contaminated. These materials are sectioned, packaged and removed. Decommissioning equipment stored in the area is removed. A radiation survey identifies other areas of contamination. Residual contamination, is removed using spot decontamination 
techniques. The EMS crane hook and sections of the contaminated cable are packaged and removed for disposal.

At the completion of these operations and after a final radiation survey of the building has been performed, the main process building may be entered on a nonrestricted basis.

\subsubsection{Dismantlement of the Liquid Waste Tank Farm}

Dismantlement operations in the tank farm begin when chemical decontamination of the process cells in the main process building has been completed. The WTEG must first be decontaminated and demolished to provide access for dismantlement of the four tanks it serves. All four tanks will have been emptied, the heels of solution in the tanks flushed with nitric acid, and the tank internals chemically decontaminated (so that no further WTEG services are required) before the WTEG is removed.

A controlling factor in the tank farm dismantlement is the inventory of high-level liquid waste at shutdown. It is assumed that the equivalent of one full tank $\left(1.14 \times 10^{6}\right.$ liters or 300,000 gallons $)$ of high-level waste and onehalf tank full of intermediate-level wastes is present at shutdown. Judicious management of the waste storage and solidification systems during the final years of plant operations could possibly reduce this inventory, thereby allowing for an accelerated dismantlement schedule. A larger liquid waste inventory would delay the tank farm dismantlement and increase decommissioning expenses.

Any waste solutions remaining in the tanks when dismantlement begins are consolidated in the last tanks to be dismantled. Just as with normal plant safety procedures, one HLLW tank is always kept empty until all high-level liquid waste has been processed through the waste solidification facility. The ILLW tank is used for receiving contaminated solutions generated during decommissioning.

\subsubsection{Waste Tank Ventilation System}

The tank farm is isolated from the main process building when chemical decontamination operations in the latter building have been completed. The 
exhaust from the waste tank vaults, normally routed to the uranium product cell, is rerouted to the ventilation filter station, and the connection between the tanks and process building is broken. The waste tank off-gas, normally treated in the vessel off-gas system in the WTEG is rerouted to the waste solidification plant through the existing pipe vault after the tanks are chemically flushed. After the internals of the HLLW tanks have been chemically decontaminated, the vessel off-gas is rerouted to the VFS. New HEPA filters are installed as necessary and HEPA filters are installed in the air inlets to the tanks.

\subsubsection{HLLW and ILLW Tank Heel Flushing}

After each tank is emptied as completely as possible, 38,000 \& (10,000 gal) of concentrated (50\%) nitric acid is introduced into the tank to dissolve deposits on the tank bottom and dilute the residual waste solution that cannot be removed using the installed pump-out jets. The solution is circulated within each tank using the installed mixing or sparging equipment and the tank is pumped down to the "residual" level with the installed pumps. For this study, it was assumed that the flushing procedure was carried out four times. Any further repetitions were felt to have only minor effectiveness. The third and fourth flushes of the HLLW tanks are done through spray nozzles installed through the tank roof.

\subsubsection{Waste Tank Equipment Gallery (WTEG)}

To gain access to the liquid waste tanks, the WTEG must first be removed. Areas in the waste tank equipment gallery are classed as radioactively hot (e.g., waste tank off-gas treatment areas), intermediate (e.g., waste tank cooling equipment areas), or cold (e.g., operating areas). Cold areas are not radioactive and can be entered on a nonrestricted basis. Hot areas contain equipment that routinely handles radioactive materials. All equipment in hot areas is considered as contaminated for disposal purposes. Equipment in intermediate areas has been potentially exposed to radioactive materials from equipment malfunctions, accidents, or through slow migration of radionuclides from contaminated to noncontaminated areas inside piping. Plant operating history and radiation surveys identify equipment that has been contaminated. Potentially contaminated equipment is treated as though it was definitely 
radioactive for disposal purposes. Equipment that is believed to be noncontaminated is disassembled in place, the potentially contaminated parts are surveyed and the equipment is disposed of based on the radiation survey results. Equipment that cannot be easily disassembled and surveyed is treated as contaminated for disposal purposes.

Dismantlement of the WTEG begins with the chemical decontamination of a11 but the cold areas of the building. Portions of the hot areas such as the waste tank diverter cell (WTDC) are designed as contact maintenance cells and have built-in decontamination spraying equipment. This equipment is used to reduce the radioactivity levels in the cell so that the remaining dismantlement operations can be carried out using direct personnel contact methods.

After chemical decontamination of the facility, a work area is prepared above the WTDC in the intermediate areas. Coolant pumps and related equipment are removed and a protective coating is applied to surfaces in the area.

A radiation survey is made of the WTDC. Temporary shielding is installed as necessary. Equipment above the HLLW diverter is removed. A hole $2 \mathrm{~m}$ by $2 \mathrm{~m}$ ( $6 \mathrm{ft}$ by $6 \mathrm{ft}$ ) is cut in the WTDC ceiling above the HLLW diverter, using drilling and explosive techniques described in Appendix E.3.3. Both the HLLW and ILLW diverters are removed, sectioned as necessary in the prepared work area, and packaged for disposal. All cutting is done using a plasma torch. During removal of the diverters, the pipes leading to the waste tanks are sealed.

The remaining piping in the WTDC is removed, and the stainless steel liner is sectioned and removed using the technique described previously for removal of other cell liners. A radiation survey is made, and areas of the cell are mechanically decontaminated as required using modified rock splitting techniques.

Equipment remaining in the intermediate area is removed next, followed by removal of equipment from the remaining hot areas and the sample cell. These areas are surveyed and mechanically decontaminated based on the survey results.

Finally, the building ventilation system filters are removed, the ventilation system is removed, equipment is removed from the cold area for salvage or commercial disposal, and the work area is removed. 
Following a final radiation survey of the WTEG, the building is demolished. A detailed description of the dismantlement procedures for the WTEG is presented in Appendix E.3.3, Volume 2.

\subsubsection{Liquid Waste Storage Tanks}

After removal of the WTEG structure, dismantlement of the liquid waste storage tanks can proceed. Because radiation levels are expected to be much lower in the ILLW tank than in the HLLW tanks, the ILLW tank is dismantled first as a system test. Dismantlement procedures can be evaluated and modified if necessary before the more difficult task of removing the HLLW tanks.

The first step in dismantlement of the liquid waste storage tanks is to excavate a working area on top of the concrete vault roof about each tank. Soil is removed so that the entire vault top is exposed. Concrete may be sprayed on the sides of the excavation to keep soil from slumping back down onto the vautt.

The final two HLLW tank decontamination flushes are carried out using decontamination sprayers installed through penetrations made in the tank and vault tops. A greenhouse enclosure is used to prevent the spread of contamination while penetrating the vault and tank top using a track dri11. After installation of the spray heads, all penetrations are sealed. A nitrichydrofluoric acid mixture is used and residual solution is circulated and removed using the existing mixing and pumpout equipment. This requires that utilities (steam and compressed air) be temporarily provided at the site.

To dismantle the waste tanks, it is necessary to make major penetrations in the tanks from the top for removal of the contaminated tank internals. To prevent the release of radioactivity to the environment and to support the operations in the tanks, a large greenhouse building designed to withstand year-round weather conditions is erected. The building is moved to a position above each of the four liquid waste storage tanks as they are dismantled. Conceptual specifications for the greenhouse building are given in Appendix E.3.6, Volume 2. Buildings of this size and design are available on the open market. 
The radiation levels in the waste tanks are expected to be relatively high even after the waste solutions are removed and the heels are flushed and diluted. Dismantlement of the waste tanks is very difficult regardless of the techniques used. Setting up a completely remote system for tank dismentlement could probably be done but would be very time-consuming, so a shielded cage was selected in this study to allow for more direct operations inside the tanks.

Special provisions are made for extensive decontamination (by ultrasonic or electropolishing techniques) of the removed parts of the waste tanks. These parts are decontaminated to the point of requirina essentialiy no shielding during waste transportation and disposal thus reducing the cost significantly for this transportation and disposal.

- ILLW Tank

After the ILLW tank is flushed the residual solution is pumped from the tank with a long-shaft pump installed through the existing valut riser. A working area is then excavated over the vault top, and the greenhouse building is installed over the tank. Special ventilation and shielding equipment is also installed.

Sections of the concrete vault top are removed next, and the shielded cage is set up for use in penetrating the tank top and then for removal of tank internals. The tank internals, tank walls and floor, and vault liner are sectioned and removed from the vault. The vault is surveyed and the concrete ceiling, walls and floor are mechanically decontaminated as necessary. Finally, drainage holes or cracks are made in the remainder of the floor of the tank vault and the cavity is backfilled.

- HLLW Tanks

Following the dismantlement of the ILLW tank, the HLLW tanks are dismantled one at a time. After the work area is excavated over the HLLW tank vault and the greenhouse building is installed, a submersible pump is used to pump out most of the residual solution left in the tank. The pump is lowered through a 10-cm (4-in.) hole that is core drilled above the tank bottom's lowest point. 
A section of the vault top is penetrated and the shielded cage is lowered into the vault and used for cutting into the tank top. The tank internals are removed in sections small enough to fit into shipping containers for waste going to geologic disposal. As the internals are removed from the tank, the radioactivity levels are measured. Sections that do not meet requirements for disposal as low-level TRU waste are decontaminated using electropolishing or ultrasonic decontamination equipment located in a specially equipped area of the greenhouse building. The tank internals are then packaged and shipped to disposal. The tank and vault liner are sectioned using a plasma arc torch and removed. These sections are also surveyed for radioactivity and further decontaminated if necessary. The concrete vault ceiling, walls and floor are mechanically decontaminated as required, and drainage holes or cracks are placed in the bottom of the vault. Finally the vault cavity is backfilled.

The above procedure is repeated until all of the HLLW tanks have been dismantled. After all of the tanks have been decommissioned, all piping and the pipe vault between the tank farm and the WSP are removed, and the greenhouse building and associated equipment is decontaminated and dismantled. A detailed explanation of the steps required to dismantle the liquid waste storage tanks is presented in Appendix E.3.3, Volume 2.

\subsubsection{Dismantlement of the Waste Solidification Plant}

Because it is necessary to process all chemical flushing solutions as liquid waste, dismantlement of the waste solidification plant (WSP) does not start until all liquid wastes from chemical decontamination of the main process building and flushing liquids from the waste tanks have been solidified.

After the final pumpout of chemical decontamination solutions from the liquid waste storage tanks, the hot pipe trench (HPT) connecting the tank farm with the WSP is sealed off where it enters the WSP. During chemical decontamination of the HLLW tank internals, this trench is used to carry tank offgas to the off-gas treatment cell in the WSP. After chemical decontamination

of the tanks, and before sealing off the HPT, the waste tank off-gas is rerouted directly to the VFS. A11 portions of the trench exterior to the WSP are removed and all contaminated materials are packaged for offsite shipment 
and disposal. Temporary but sturdy greenhouse structures are used to isolate sections of the trench from the atmosphere while the trench is being removed.

Dismantlement of the WSP begins with the chemical decontamination of process equipment (both internal and external) and cell walls. Chemical decontamination procedures as discussed in Section 7.2 are followed, using installed equipment. Used chemical decontamination solutions are routed to the calciner feed tank and processed through the solidifier using normal operating procedures. Solidification of the decontamination solutions aids in further chemical decontamination of the internals of the solidification equipment.

The equipment removal phase begins in the waste vitrification cell (WVC). Normal remote maintenance techniques are used to remove equipment to the hot maintenance cell (HMC) for disassembly and packaging. All operations are performed remotely using the WVC cranes and installed manipulators and viewing windows. A plasma arc torch is used to cut equipment free from piping and support brackets. Piping that penetrates cell walls is cut, sealed at both ends and left in place. These sealed sections of pipe are retrieved during building demolition operations.

The in-can melter furnaces and calciner are cut up in the HMC to fit containers acceptable for geologic disposal. The outer shell of the furnaces are sectioned with a plasma torch, and the underlying insulation is stripped out. Ceramic insulation is broken up by drilling and rock splitting, if necessary, and removed. The inner vessel, interior piping, and other hardware is sectioned with a plasma torch. The sectioned equipment is placed in waste disposal containers and removed from the HMC through the shielding door for shipment and disposal offsite. All sectioning of the equipment is done remotely using the installed remote equipment. Loose contamination generated during these activities is removed using a specially designed vacuum cleaning system.

The canister decontamination cell (CDC) is expected to have relatively low levels of radioactivity following chemical decontamination. During normal 
operations of the facility, this area is kept clean to ensure that canisters leaving the cell are not excessively contaminated externally. To initiate dismantlement of the CDC, the can transfer aisle between the $\operatorname{CDC}$ and the FRSS is drained and sealed at both ends. Temporary shielding is installed over hot spots using the existing cranes, manipulators and shielding windows in the CDC. Equipment is then removed from the CDC using direct personnel contact methods. Equipment is cut free with plasma arc torches, sectioned if necessary, taken out of the cell through the access plugs to the warm service gallery (WSG), packaged and removed for shipment and disposal offsite.

Equipment with high radiation levels is removed from the off-gas treatment cell (OGTC) using the installed shielding windows and manipulators. The equipment is removed through the OGTC ceiling hatch to the HMC using the HMC crane. The equipment is sectioned as necessary, packaged and removed for shipment and disposal offsite. Temporary shielding is placed over hot spots.

After rilloval of equipment from the cells, removal of cell liners and mechanical cecontamination is carried out starting with the waste vitrification cell i $: 3)$. After installation of temporary shielding over hot spots (using the icinote equipment), liner removal is performed using direct personnel contact methods. Manipulators are removed and their wall sleeves plugged, and protective covers are placed over shielding windows before liner removal begins. The liner removal technique used is the same as that described previously for removal of the cell liners. The liner is sectioned in place using plasma torches and packaged in the HMC for offsite shipment. Liner removal generally proceeds from the top of the cell toward the bottom. Concrete under the liner is decontaminated to the unrestricted use levels described in Section 6, using drilling and rock-splitting techniques. (Explosives may be used if large areas of concrete must be decontaminated.) The concrete surrounding the anchors holding the liner to the concrete wall are expected to have the highest potential for contamination. Liners are removed from the CDC and the OGTC using procedures similar to those described for the WVC.

When it is no longer required for sectioning and packaging activities, the HMC is dismantled. Equipment and cell liner removal techniques used in the HMC are similar to those described above for other cells. 
A radiation survey of the remaining galleries and operating areas of the WSP wi11 identify areas that need further decontamination to reach unrestricted use levels. Contamination is expected to be localized. Contaminated equipment and piping is removed using conventional maintenance techniques or cut with a portable plasma torch and removed. Contaminated concrete is removed by drilling and rock-splitting or jackhammering.

Following final mechanical decontamination operations in the WSP, the ventilation system is decontaminated and removed. HEPA and roughing filters are removed using normal maintenance procedures. A temporary HEPA-filtered ventilation system bypass that exhausts into the vent trench to the VFS is installed during decontamination operations in the WSP ventilation system. Ventilation ductwork is sectioned, sealed at both ends, packaged and removed. Stainless steel liners are removed from ventilation trenches by sectioning in place with a plasma arc torch. Contact operations are expected to be used for ventilation system removal after ventilation filters have been removed.

The WSP ventilation trench is sealed off where it enters the VFS. The ventilation trench is removed using techniques similar to those described previously for the hot pipe trench.

A final radiation survey of the WSP building will verify that radiation levels are below the unrestricted levels presented in Section 6 . The building is then demolished with the other decontaminated facilities on the site during the demolition and site restoration phase.

Details of the procedures for dismantlement of the waste solidification plant are presented in Appendix E.3.4, Volume 2.

\subsubsection{Dismantlement of the Fuel Receiving and Storage Station (FRSS)}

The FRSS generally undergoes chemical decontamination, equipment removal, and mechanical decontamination operations similar to those in the main process building. Details of those steps are not repeated here. Considerations specific to the FRSS are discussed in this section.

The procedures followed when a leaking fuel bundle is received and the constant recirculation and deionization of the pool water during plant operation 
rinimize the expected contamination levels in the FRSS. The contamination levels are expected to be low enough to allow for decontamination by direct personnel contact. Most areas exposed to potential contamination are stainless steel that can generally be spot decontaminated. Concrete portions of the FRSS are expected to be essentially free of contamination.

The equipment and stainless steel liners from the pools, the water treatment equipment and piping, and the ventilation ducting and filtration system will likely be moderately contaminated and will require appropriate handling and disposal. Remaining equipment in the building is handled and disposed of using techniques dictated by radiation readings. The cranes used for handling the incoming casks and fuel bundles serve the entire area. These cranes are capable of lifting any loads required in the decontamination operations.

Dismantlement in the FRSS begins with draining and decontaminating the pools followed by a radiation survey. The pool water is deionized using installed ion exchange equipment (upgraded if necessary) to radioactivity levels that permit release to local water bodies or to the atmosphere consistent with the principle of ALARA. As the pools are drained, the walls and floor are sprayed with water or steam. Most radioactive particulates that may have settled out on the storage pool floor are removed with an underwater vacuum cleaner when about 2.0 meters $(6 \mathrm{ft})$ of water remain in the pools. Liquid solutions from chemical decontamination are pumped to a storage tank and solidified by a contractor who moves onsite with a portable solidification unit. The equipment is then removed from the pools and deionization area.

The stainless steel pool liners are removed using a plasma arc torch and sectioned in preparation for packaging and shipment offsite for disposal. The concrete pool is mechanically decontaminated to reduce radiation levels to the required unrestricted use levels. Drilling and rock-splitting or jackhammering are used. Other work areas in the FRSS are spot decontaminated as necessary. The FRSS ventilation filters are removed using standard operating techniques and the ductwork is decontaminated and removed. A final radiation survey is made to ensure that unrestricted use radiation levels have been reached. 
Details of the procedure for dismantlement of the FRSS are presented in Appendix E.3.6, Volume 2.

\subsubsection{Dismantlement of the Auxiliary Facilities}

This activity involves chemical decontamination, equipment removal, and mechanical decontamination of remaining radioactively-contaminated facilities on the site, including the filter building, the hot and cold laboratory area, the analytical filter station, the process area for vaporizing the acid fractionator overheads, and the process stacks.

Decontamination of the filter building and main process stack (and associated ducts, etc.) begins only after all the areas that exhaust through the ventilation filter station have been decontaminated. Prior to decontamination of the hot and cold laboratory area and the analytical filter station, a11 laboratory operations will have been terminated and all noncontaminated equipment not needed for dismantlement will have been removed.

It is expected that the only areas of significant contamination in the filter building will be the ventilation filter station and associated ductwork. The ventilation filter station contains the final banks of exhaust filters for the main process building. Radiation levels should permit contact operations in this area. A temporary filter station is installed in the exhaust from this building to collect radioactive dust loosened during decontamination of the filter building. The filters are removed using existing operational procedures. This activity is followed by a radiation survey of concrete walls, floor, ceiling and shielding to detect hot spots. Concrete surfaces will probably be contaminated at low levels over wide areas. The inside surface of the ventilation filter station is scarfed as necessary using the explosive techniques described previously. Rubble is packaged and shipped as previously discussed. Blowers are disassembled, surveyed and disposed of in the appropriate manner, probably as contaminated materials. Ductwork is sectioned and packaged for shipping and disposal as contaminated materials. 
Decontamination of the hot laboratories is done using standard techniques for such areas. Glove boxes and hoods are filled with self-setting foam, sectioned as necessary and removed as described in Appendix E.3.1.6, Volume 2. Contaminated equipment is packaged and shipped as described previously. Concrete is mechanically decontaminated by one of the several techniques previously mentioned. The choice depends upon the type and amount of radioactivity present. A final survey of the area is made to assure that hazardous contamination levels have been removed.

The analytical filter station is decontaminated after completion of operations in the hot laboratories. The filters are removed using existing procedures. Contaminated ductwork and blowers are filled with foam, removed and packaged for shipment. Concrete surfaces are spot decontaminated as necessary.

Decontamination of the main stack, acid fractionator overhead vaporizer system and ductwork from the VFS to the main stack is the final activity before demolition and site restoration begins. The stack is a steel cylinder $100 \mathrm{~m}$ in height. It is sealed at both ends, cut at the base and lowered to the ground as a unit by a subcontractor. The stack is then sectioned using conventional cutting techniques. The inner surface of the stack in the vicinity of each cut is chemically decontaminated manually before the cut is made. The sections of stack are sealed at each end and shipped as their own shipping container. Similar techniques are used to dismantle the service concentrator (SC) stack and the cold chemical (CC) stack.

The ductwork from the VFS to the main stack is above grade. It is sectioned in place using mechanical cutters. The sections are sealed at each end and shipped offsite.

Contaminated portions of the acid fractionator overhead vaporizer system and the stack auxiliaries are removed and packaged for shipment. The structures in the stack area are surveyed for radiation and decontaminated as necessary. 


\subsubsection{Structure Demolition and Site Restoration.}

This phase consists of the activities required to demolish the remaining structures, dispose of the resultant noncontaminated rubble and restore the site to its pre-facility condition. Prior to building demolition, all decontamination operations will have been completed and salvagable noncontaminated equipment removed from the structures. During and after building demolition, but prior to backfill, comprehensive radiation surveys of the site are performed frequently to assure that radioactivity levels meet the unrestricted use category limits. The site contamination levels presented in Section 5.1 are based on conservative assumptions, and no significant site contamination is expected to remain. Thus, no site clean-up is performed in this study. If it is found to be necessary, the top few inches of soil in the contaminated areas are removed, packaged, and shipped for disposal. The results of this survey are the basis for the termination of the "possession-only" license authorization.

The structures demolished during this phase are the main process building and fuel receiving and storage station, the filter building, the waste solidification building, laboratories, and the main stack auxiliaries building. It is assumed that building demolition is accomplished through a subcontractor. All conventional demolition methods are assumed to be acceptable. The demolished excavations are backfilled with onsite soil and rubble. The subcontractor is responsible for the disposal of any excess demolition rubble, if it exists, at a local landfill. However, essentially no significant excess noncontaminated rubble is expected. A small amount of contaminated piping, sealed at both ends during decontamination because its removal was unfeasible, still remains in the structures when demolition begins. Decommissioning personnel work with the subcontractor to separate this material from the rubble and package and ship it to the contaminated material burial site.

When radiation surveys provide assurance that all hazardous materials have been removed from the site, the subcontractor backfills all cavities. The site is then graded to conform with the surrounding terrain and planted with native vegetation.

The plant operating contractor then applies for regulatory release of site for unrestricted use. 
PROTECTIVE STORAGE MODE

The set of procedures presented in this section is used to place the reference fuel reprocessing plant in a condition that provides protection to the public and the environment with limited maintenance and surveillance requirements. Areas of the facility that are accessible during the surveillance period are decontaminated to unrestricted use levels. All contaminated materials that are not removed from the facility are placed in the process cells or other contaminated areas of the facility. These areas are isolated from the remainder of the facility by structurally substantial physical barriers. After the facility is placed in protective storage, surveillance and maintenance activities are 1 imited to environmental and facility radiation monitoring and inspection, and repairing the physical barriers, structures and instrumentation. Security is provided by the fence around the immediate facility site (about 0.12 square kilometers or 30 acres), high security locks on entrance doors and electronic alarms. The remaining portion of the site may be released for restricted use during the surveillance and maintenance period. The facility will remain in protective storage until final dismantlement takes place. A detailed account of the activities required to place the facility in protective storage are kept and made part of the public record. This record will be used to provide guidance for the final dismantlement of the facility.

\subsubsection{Overview of Protective Storage Activities}

For this study, the facility was considered to be divided into five sections. These facility sections are:

- main process building

- liquid waste storage area

- waste solidification plant (WSP)

- fuel receiving and storage station (FRSS)

- auxiliary facilities (filter building, stack, and laboratories)

The protective storage operations in each section of the facility are generally divided into the following six major stages:

- planning and preparation

- chemical decontamination

- mechanical decontamination and fixing of residual contamination 
- equipment deactivation

- isolation of contaminated areas

- final preparations for surveillance and maintenance.

Planning and preparation activities (as described in Section 7.1) are carried out concurrently with the final two years of plant operation. Chemical decontamination of the facility is performed to reduce radiation levels in the facility. This step, common to all decommissioning modes, was discussed in Section 7.2.

A sequence of activities for placing the reference facility in protective storage is shown in Figure 7.4-1. After completion of chemical decontamination of the main process building, equipment is secured, barriers and walls are emplaced, and monitoring equipment is installed. All utilities not needed during protective storage activities are disconnected and the ventilation system is shut down. After a 11 liquid waste inventories and chemical decontmination solutions have been removed from the liquid waste storage tanks, the tanks are flushed and the tank farm is decommissioned. When all process wastes and decontamination flushing solutions have been solidified, the waste solidification plant is deactivated. The FRSS (which serves as a temporary storage area for solidified waste canisters) is placed in protective storage next, followed by the auxiliary facilities.

Following final preparations for surveillance and maintenance of the plant during protective storage, the facility is placed in a phase of interim care, characterized by activities limited to environmental and facility radiation monitoring and inspecting and repairing physical barriers and other structures. Following this period of interim care, the facility is dismantled.

An outline of the post-shutdown activities employed to place the facility in protective storage is presented in Table 7.4-1. Portions of these activities in various sections of the facility may overlap and proceed concurrentiy. The activities in Table 7.4-1 are summarized below and where necessary are discussed in detail in Volume 2, Appendix E.4. 


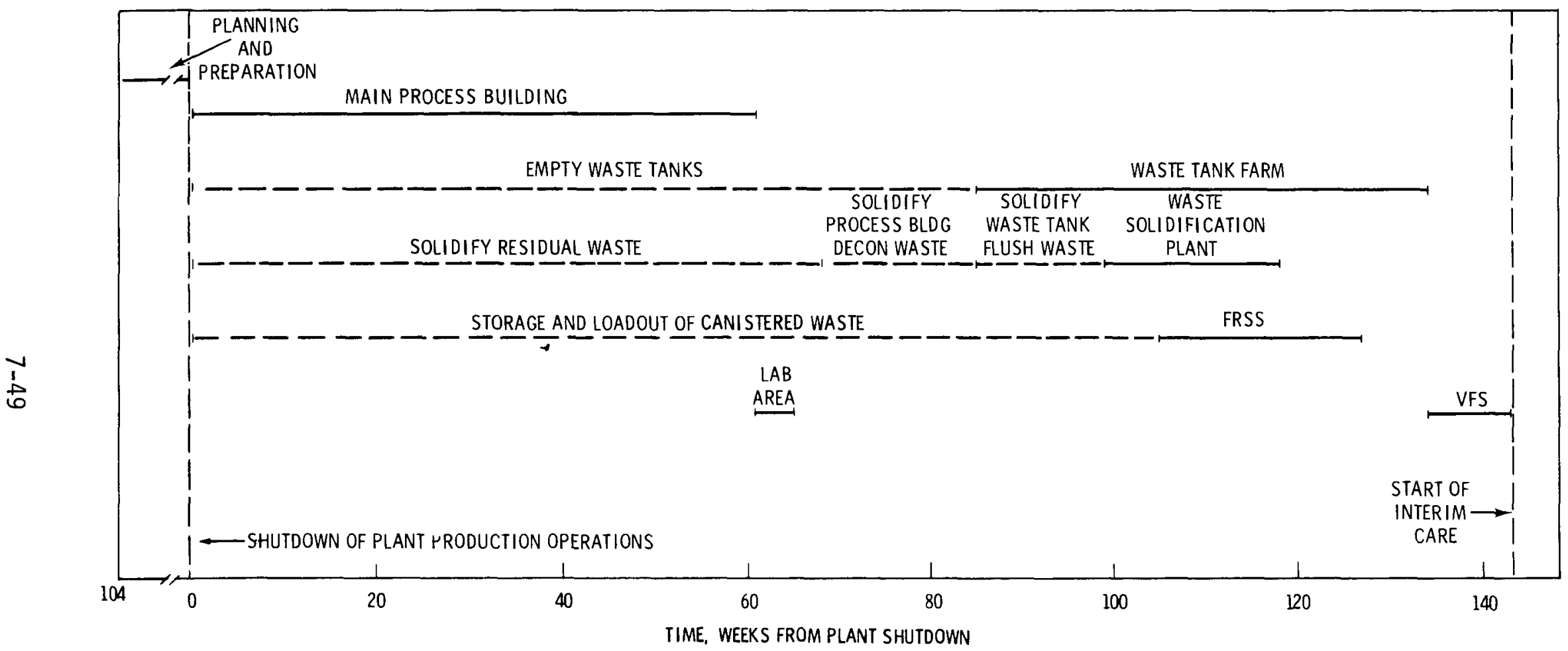

FIGURE 7.4-1. Sequence of Activities for Placing the Reference Fuel Reprocessing Plant in Protective Storage 
-

• 
$-9$ 


\subsubsection{Protective Storage Activities in the Main Process Building}

Operations in the main process building include all tasks required to prepare the facility for the interim care phase. Equipment and structural materials in accessible areas of the main process building that are significantly contaminated with radioactivity are removed and placed in a process ce11. A11 systems and equipment in the main process building that are not required to be in operation during the surveillance and maintenance phases are deactivated. Safety-related systems such as fire protection and radiation monitoring equipment are inspected and placed in a condition that provides maximum reliability during the surveillance period. Areas of the building that contain significant radioactive contamination are isolated from the remainder of the facility by installing "hard" barriers to block pathways for migration of contamination or access by people. Exterior doors are welded closed and additional safety and security devices required for the survei1lance and maintenance period are installed.

\subsubsection{Decontamination and Fixing of Residual Contamination}

As part of the mechanical decontamination step, equipment in accessible areas of the facility that is contaminated with radioactivity is removed and placed in an isolated area of the plant. The HA centrifugal contactor, the feed centrifuge, and the IBX electrocolumn extend through the ceilings of the process cells into the contact equipment removal station (CERS). These pieces of equipment are removed using existing maintenance procedures and stored in a process cell. New shield plugs are fabricated and placed in the openings left by the removed equipment. Steel plates are bolted and sealed over these plugs using the procedures outlined in Appendix E.4.1, Volume 2.

Al1 master-slave manipulators are removed from their sleeves using standard maintenance techniques, placed in noncombustible containers, and stored in the crane equipment maintenance gallery (CEMG). These will be retrieved and used during final dismantlement of the facility. Steel plates are welded over the manipulator sleeves.

Following the chemical decontamination of process equipment and cells, it is necessary to remove significant amounts of radioactive contamination from 
areas outside the process cells that are not isolated during protective storage. Chemical and mechanical decontamination procedures are used.

The areas to be decontaminated include the following:

- pipe galleries (TPIG, LIPIG, FPIG)

- service concentrator gallery

- sample and analytical cells

- glove boxes in the AVOS and PNOS

- glove boxes and hoods in the hot laboratories

- hull monitor maintenance gallery

- viewing and operating stations (LVOS, GVOS, TVOS)

- EMS, CCS, CERS area

- manipulator repair station

- cask loading station

- radioactive laboratories.

A variety of decontamination methods is used. Many areas are cleaned using simple "janitorial" techniques such as vacuuming, sweeping or scrubbing with cleaning agents compatible with the waste treatment system. Acid-proof sponges soaked in decontamination solution are used on small areas where chemicals are effective. Larger areas are decontaminated using a portable high pressure decontamination solution sprayer. Areas of contaminated concrete that cannot be cleaned by other methods are removed by chipping, drilling and rock-splitting or jackhammering. These areas are grouted smooth after the contamination is removed if they represent an industrial safety hazard.

Areas of the main process building that will be accessible during the surveillance and maintenance period are generally decontaminated to unrestricted use levels. However, areas of very low levels of contamination that cannot be readily removed are fixed in place by high-integrity painting. The painting involves applying at least one coat each of two distinctively-colored paints and is applied to prevent the contamination from becoming airborne. Radiation warning signs are placed near the painted areas. The location and characteristics of each such area are noted in the permanent records of the 
protective storage operation. Equipment in these areas that cannot be adequately decontaminated is removed and placed in the remote maintenance and scrap cell where it will remain during the interim care period.

A sequence of events for decontaminating and sealing glove boxes and hoods and the Sample and Analytical Cells is presented in Appendix E.4.2, volume 2.

Residual plutonium contamination will remain in the plutonium product cell and the plutonium nitrate cells after the chemical decontamination procedures have been completed. Significant amounts of smearable contamination are removed using contact operations, and the remaining contamination is fixed in place.

Decontamination operations in the PPC and PNSL are performed by personnel in sealed suits supplied with fresh air. A mobile, adjustable-height metal scaffold is installed through the cell hatch for the operations in the PPC. Removal of the 3P concentrator and reboiler, located $3 \mathrm{~m}(10 \mathrm{ft})$ below the hatch, may be necessary for installation of the scaffolding. This equipment is cut away and placed elsewhere inside the cell.

Areas in the cells with significant plutonium contamination are identified by radiation surveys. Smearable contamination on concrete surfaces is removed with a portable high pressure decontamination sprayer. The sprayer can also be used on large areas of contaminated stainless steel. Localized contamination on process equipment and the stainless steel cell floor liners is removed with acid proof sponges soaked in decontamination solution. After a final radiation survey, the entire cell is painted with a nonflammable contamination-fixing agent. The scaffold used in operations in the PPC is left in the cell.

\subsubsection{Equipment Deactivation}

Noncontaminated equipment and systems in the facility that are not required to be in operation after the decommissioning phase are placed in a condition that provides maximum safety and requires minimum maintenance. Whenever possible, equipment is left in a condition that permits salvage at a later date. Equipment deactivation procedures are coordinated with facility 
decontamination operations. In some areas decontamination must be carried ou. before equipment deactivation, while in other areas the opposite approach may be necessary. The particular method used to deactivate each system or piece of equipment is identified during the planning phase. All equipment, valves, electrical circuit breakers, etc., are tagged when deactivated. This tag identifies the piece of equipment, the system it is in, and its condition.

The first step in equipment deactivation is a safety audit of all pumps and pipes used for organic materials or hazardous chemicals to ensure that al1 flammable and other dangerous materials have been removed. Electrical service is disconnected from all pumps not required to be in operation during the surveillance and maintenance period. All pipes that penetrate the exterior walls of the building are blanked.

Systems inside the main process building are deactivated by a variety of methods. Some systems are isolated using installed valves with handles removed. Pipes that have contained hazardous chemicals are blanked. Other systems are drained and left open to the atmosphere. A fresh coating of fire retardant material is applied to all electrical cable runs. Electrical service and other utilities are disconnected from instrumentation and other equipment not required to be in operation during the interim care period.

Because the waste storage systems will be in operation for a time after the process system has been decommissioned, piping and ventilation systems from the main process building to the waste tank equipment gallery, waste tank cells, and other auxiliary facilities are rerouted before decommissioning of the waste system. The condensate from the waste tank knock-out pots is drained back to the waste tanks. The off-gases from high level liquid waste storage, normally treated in the vessel off-gas system of the main process building, are rerouted to the treatment areas in the waste solidification plant and exhausted to the main stack. The ventilation system of the waste tank diverter cell, which is normally run to the process cells, is rerouted to the hot areas of the WTEG. The pipe tunnel between the main process building and the liquid waste storage facility is sealed when no longer required. The waste tank cell ventilation is rerouted to the waste solidification plant. 


\subsubsection{Isolation of Contaminated Areas}

Areas containing significant amounts of radioactive contamination are isolated from the remainder of the facility by installing barriers to block potential pathways for the migration of contamination. Areas in the main process building that are isolated include:

- all process cells

- plutonium nitrate cells (PNC)

- sample and analytical cells and plutonium glove boxes (SAC/PGB)

- service concentrator gallery (SCG)

- head tank gallery/pulser equipment gallery (HTG/PEG)

- crane and equipment maintenance gallery (CEMG).

All piping, ventilation, instrumentation, equipment and other penetrations and all access openings into these areas are sealed.

Steel plates are sealed over all shielding windows, shielding plugs, and passing ports. The oil is drained from oil-filled shielding windows. The shielding doors leading to the process cells from the filter piping and instrument gallery and the airlocks leading to the service concentrator gallery and the HTG/PEG are welded closed. The perimeters of the process cell ceiling hatches are filled with a sealant to provide an airtight seal. All piping and instrument lines running from the piping and instrument galleries to the process cells are blanked. Contaminated piping remaining in the pipe galleries is sealed at both ends and left in place. The shafts of the fuel transfer conveyor, shear feed ram drive, and the fuel diverter drive that penetrate the walls of the remote process cell are cut flush to the walls and covered. The hatch between the cask loading station and the remote mainteance and scrap cell (RMSC) is disconnected from its drive shaft and sealed with a steel cover. A steel plate is bolted over the sand chute between the grade viewing and operating station (GVOS) and the RMSC.

A11 penetrations to the SACs, including the shielding windows, the shielding doors, the transfer drawer, and the manipulator sleeves, are sealed as described in Appendix E.4.1, Volume 2. One of the SACs has access to a pneumatic transfer system connecting the cells with the hot laboratories. A steel plate welded over the system isolates the SACs from the laboratories. 
The chute leading from the SACs to the remote maintenance and scrap cell is also sealed with a steel plate. Details of sealing procedures are given in Appendix E.4.1.

The final step in isolating a contaminated area is sealing the ventilation intake and exhaust ducts. This step is coordinated with decontamination and isolation of the ventilation system. A HEPA-filtered vent is installed in each independently isolated area as backup protection in the event that changes in air pressure and temperature or other causes result in the failure of seals. These vents will be inspected and maintained during the interim care period.

The main process building ventilation system remains in operation while the selected contaminated areas are being isolated. Filters are removed and the filter housings, ventilation exhaust ductwork and the filter niche, are decontaminated and isolated after the other contaminated areas have been sealed. Temporary rerouting of portions of the ventilation system is likely to be required during these operations to assure proper contamination control.

Filters are removed using procedures followed during plant operations. Al1 ductwork exhausting from contaminated areas and all filter housings are chemically decontaminated. Decontamination flushes generally follow procedures used during plant operation. Flush solutions include hot water, concentrated nitric acid and other chemicals as necessary. After chemical decontamination, contaminated ductwork and filter housings are dried and isolated from other portions of the facility. A HEPA-filtered vent is installed in each independently isolated section of the ventilation system.

The filter housings that are isolated include the analytical filter station, the contact cells filter housing and the separate filter systems for the PPC, SAC and PNSL. After the filters have been removed and chemical decontamination has been completed, intake and exhaust ductwork is closed by welding steel plates over the openings. Airlock entrances to walk-in filter banks are welded closed after the ductwork is sealed. Access openings for changing filters in other housings are sealed in the appropriate manner. Other penetrations into the housings such as those for instrumentation or air sampling points are also sealed. 
The final step in isolating the contaminated portion of the main process building is sealing the ventilation ductwork by welding. Intake ducts are sealed first. Exhaust ductwork is sealed after chemical decontamination of downstream ductwork and filter housings has been completed.

The contaminated areas of the process building are sealed in five independent sections. The UPC, ILC, HILC and HLC form one section. The pipe vault from the UPC to the liquid waste storage facility is sealed, intake ductwork to the UPC from the piping and instrument galleries is sealed and the common exhaust duct for these cells is sealed where it enters the contact cell filter housing.

The HTG/PEG is also part of this isolated section. The airlock entrances to the HTG/PEG are sealed and a common HEPA-filtered vent for the four cells and the HTG/PEG is installed in a wall of the HTG/PEG. The PPC is isolated independently. Intake ductwork from the HTG/PEG is sealed and exhaust ductwork is sealed where it exits from the PPC filter housing. The HEPA-filtered vent for this cell is installed in the cell ceiling.

The third independently isolated section is the RPC, RMSC, and CEMG. The exhaust ductwork from the RPC and RMSC is sealed where it exits the filter housings for these areas in the filter niche. Intake ducts from the cask loading station to the CEMG, from the GVOS and hull monitor maintenance gallery (HMMG) to the RPC and from the LVOS and FPIG to the RMSC are sealed. A common HEPA-filtered vent for these areas is installed in the ceiling of the CEMG.

The SACs form another independent section. The intake duct work from the AVOS is sealed and the exhaust ductwork is sealed where it exits the SAC filter housing. The HEPA-filtered vent for this area is installed in a wall of the SAC. The glove boxes in the AVOS are isolated independently. The intake duct work and the exhaust stack from the service concentrator gallery are sealed. The vent for this gallery is installed in the sealed airlock doors.

The plutonium glove boxes and plutonium nitrate cells also form an independent unit. The intake ducts from the operating galleries to the glove boxes and the exhaust ducts from the PNC filter housing are sealed. The vent this area is installed in the plate sealing the intake ductwork. 
As the final step in isolating the main process building ventilation system, the main intake and exhaust ducts for the building are blanked near the point where they enter the building. The chemical off-gas stack is also sealed. HEPA-filtered vents are installed in locations inside the building that are easily accessible for inspection and maintenance.

\subsubsection{Final Preparations for Surveillance and Maintenance}

The final preparations for surveillance and maintenance of the main process building are coordinated with the isolation of the ventilation system. Most exterior doors to the facility, including the vehicle doors in the cask unloading station, are welded closed. High security locks and air-tight gaskets are installed on the remaining exterior doors and an electronic intrusion alarm system is installed to detect unauthorized entry into the facility during the interim care period.

HEPA-filtered vents are installed on an outside wall in the EMS and plutonium nitrate operating gallery. These vents permit the building to "breathe" when temperature and pressure changes occur, while maintaining barriers to the release of contamination from the isolated areas of the building. The HEPA filters in these vents are located inside the building. The exterior portion of the vent is designed to prevent the HEPA filter from being damaged by weather or vandalism. The vent is located high on the exterior walls to discourage attempts at vandalism or damage from animals. These vents are inspected periodically and maintained during the interim care period.

Safety systems that remain in operation during the interim care period are upgraded as necessary. Fire detection, fire fighting and automatic radiation detection equipment is refurbished and expanded as necessary. A remote readout capability is installed in a neighboring nuclear facility or local law enforcement or commercial security agency. Additional radiation alarms are installed near the HEPA-filtered vents from the process cells and plutonium nitrate cells.

When they are no longer required for decommissioning work, all cranes in the facility are disabled. Electrical power is disconnected, the circuit breakers serving the cranes are removed and the crane cables are removed and disposed. 
The main electric power supply for the main process building is disconnected and replaced with a small power supply with sufficient capacity to service the small amount of equipment in operation during the interim care period.

\subsubsection{Protective Storage Activities in the Liquid Waste Tank Farm}

The liquid waste storage facility is placed in protective storage after the inventory of liquid waste and decontamination solutions generated during chemical decontamination of the main process building have been solidified. A controlling factor in the deactivation of the tank farm is the inventory of wastes at shutdown. It is assumed that the equivalent of one full tank $\left(1.14 \times 10^{6}\right.$ e or $\left.300,000 \mathrm{gal}\right)$ of high-level waste and one-half tank full of intermediate-level waste are present at shutdown. Judicious management of storage and solidification systems during the final operating years of the plant could possibly reduce this inventory, thereby allowing for an accelerated decommissioning schedule.

\subsubsection{Waste Tank Ventilation System}

The waste tank equipment gallery is placed in protective storage after the tanks have been isolated. All piping and ventilation connections between the liquid waste storage facilities and the main process building are blanked before protective storage operations in the tank farm begin. This necessitates rerouting the waste tank off-gas system and waste tank cell vent system to the waste solidification plant. The ventilation exhaust from the waste tank equipment gallery is routed directly to the ventilation filter station. The VFS remains in operation until protective storage procedures in the tank farm have been completed.

\subsubsection{Waste Tank Heel Flushing}

The pump-out jets in the liquid waste storage tanks are located a few centimeters from the bottom of the tank. These jets leave a heel of about 11,000 \& liters $(3000 \mathrm{gal})$ of solution that cannot be pumped from the tanks. Radioactivity levels expected in the tanks at shutdown are given in Section 5.4. Radioactivity levels in the tanks are reduced through four successive flushes with $38,000 \&(10,000 \mathrm{gal})$ each of concentrated (50\%) nitric acid. The tanks 
are pumped down following each flush, and the used flush solutions are transferred to the waste solidification plant for processing.

\subsubsection{Protective Storage Procedures for the Intermediate Level Liquid Waste Tank}

Following flushing of the ILLW tank, a long shaft pump inserted into the tank through an existing access column in the tank top is used to remove most of the residual "heel" from the tank. An 11,000-l water flush is used to dilute residual acid in the tank and the tank is pumped down again. An acid resistant inorganic absorbant (for example, a synthetic calcium silicate) is injected over the tank bottom to absorb excess liquid in the tank. The access hole is sealed, and process piping, coolant piping, and ventilation piping from the tank to the WTEG are blanked.

\subsubsection{Protective Storage Procedures for the High Level Liquid Waste Storage Tanks}

The residual liquid remaining in each tank after the final flush is removed by installation of a submersible pump through the tank top. A working area is excavated over the low end of the tank, exposing a small area of the vault top. A temporary greenhouse structure is placed over the working area while the vault and tank top are being penetrated and the solution is being pumped out. Temporary shielding may be installed over the exposed vault top if necessary to reduce personnel exposure.

The vault top is penetrated by core drilling a 10-cm (4-in.) diameter hole. A capped pipe is sealed inside the hole, the tank top is penetrated, and the submersible pump installed. The pump discharge runs through airtight gasketed seals in the tank top and pipe cap.

The residual liquid is pumped to the diverter in the WTEG through a temporary pipeline and distributed from there to the waste solidification plant for processing. The general layout of the temporary pipeline is shown in Figure 7.4-2. The pipeline is installed underground at a depth at which the overburden provides the required radiation shielding. The pipeline is double walled, with the inner tubing constructed of $304 \mathrm{~L}$ stainless steel. A vacuum is maintained in the pipe annulus, and aerosol radiation monitors are installed to detect leaks that might occur. 


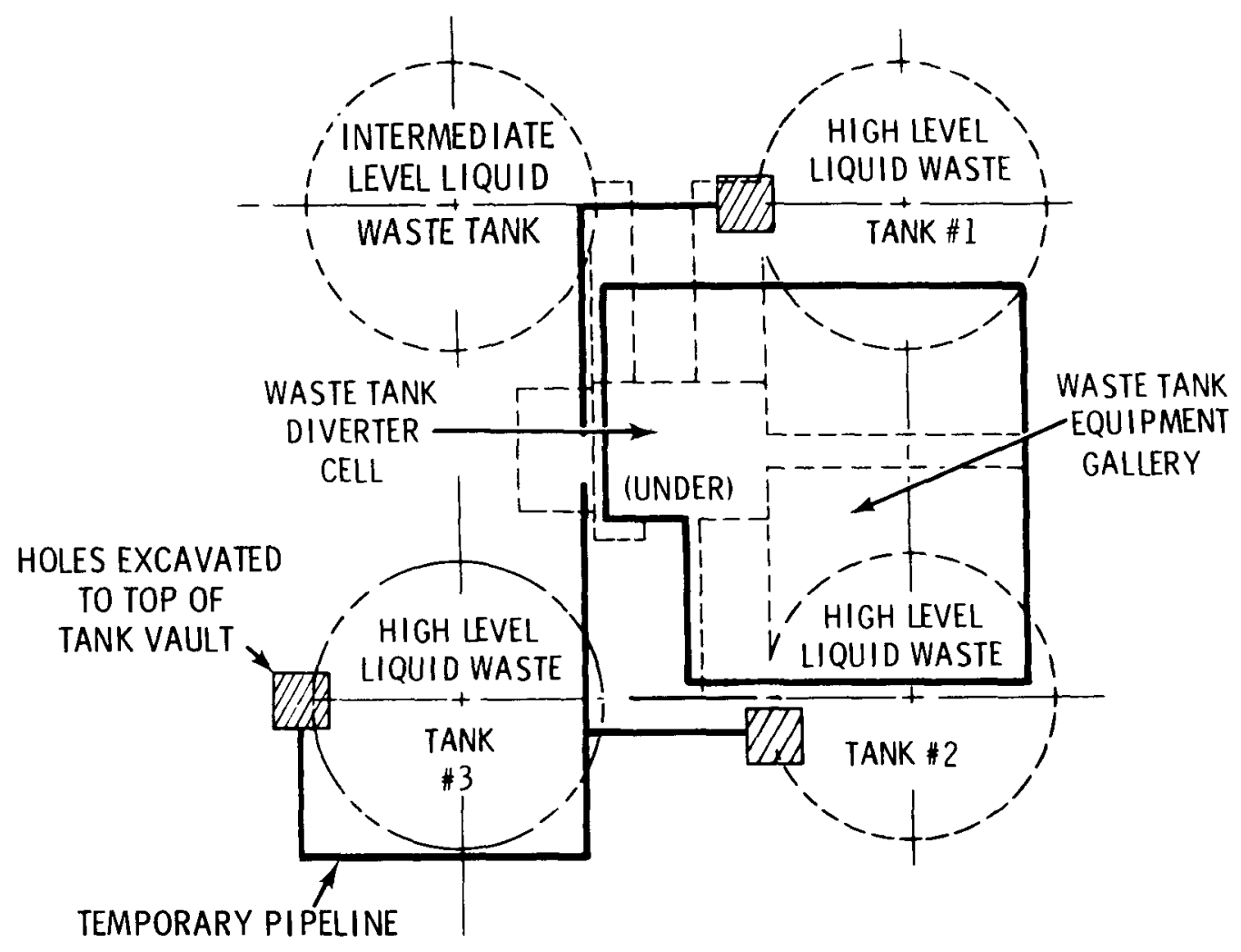

FIGURE 7.4-2. Temporary Pipeline for Pumping Residual Liquid from High Level Waste Tanks

After the residual liquid has been pumped from the tank, the tank is flushed with about 11,000 \& $(3,000 \mathrm{gal})$ of water to dilute remaining acid and pumped empty again. The pump is then removed and an acid-resistant inorganic absorbant is injected over the tank bottom to aborb excess liquid in the tank.

\subsubsection{Protective Storage Procedures for the Waste Tank Equipment Ga11ery}

The waste tank equipment gallery (WTEG) is placed in protective storage using techniques similar to those described previously for the main process building. Highly radioactive areas are chemically decontaminated using techniques similar to those previously described for the process cells. Diverter control mechanisms are removed and placed in the diverter cell which is then sealed. Smearable contamination is fixed with paint or removed. Contaminated equipment and piping is removed from areas with moderate or low levels of contamination and placed in an area that will be isolated during the interim 
care period. Contaminated equipment and piping are removed to the "hot" area. of the WTEG and the area is sealed. A HEPA-filtered vent is installed between the "hot" area and remainder of the building. Al1 noncontaminated equipment, piping, and other systems not needed during the interim care period are deactivated. Fire detection, fire fighting and automatic radiation detection equipment are upgraded as necessary, intrusion alarms are installed and remote readout capability is provided. Areas of the WTEG that are isolated include the diverter cell, the cells containing the HLLW off-gas treatment equipment, the ventilation filter housing and contaminated ductwork. HEPA-filtered vents are installed in these areas. Following a final plant radiation survey the doors are welded closed or secured with high security locks as was done in the main process building.

Details of the activities required to place the liquid waste storage facility in protective storage are presented in Appendix E.4.3, Volume 2.

\subsubsection{Protective Storage Activities in the Waste Solidification Plant}

Before the waste solidification plant is placed in protective storage, process wastes from chemical decontamination of the main process building and flushings from the liquid waste tanks must be solidified.

Protective storage operations within the WSP begin with the chemical decontamination of process equipment (both external and internal) and ce 11 walls. Standard chemical decontamination procedures (discussed in Section 7.2) are followed using the installed equipment. Chemical decontamination solutions generated by this operation are routed to the calciner feed tank and solidified using normal operating procedures. Processing of these flush chemicals further decontaminates the processing equipment internally. Next, the can transfer aisle connecting the canister decontamination cell (CDC) and the fuel receiving and storage station (FRSS) is drained and sealed at both ends.

In the waste vitrification cell (WVC) the electrical supply to the furnaces is disconnected and the umbilical systems are disabled using the existing remote maintenance equipment. All piping penetrations through walls into shielded cells are severed and sealed. $0 i l$ is drained from oil-filled shielding 
windows. A11 master-slave manipulators are removed from their cells and stored in the HMC for use during final dismantlement of the facility. Steel plates are welded over the manipulator sleeves, transfer locks, and shielding windows. All shielding plugs are welded in place.

Significant amounts of radioactive contamination are removed from areas outside the process cells that are not to be isolated during protective storage. The chemical and mechanical decontamination procedures used in the main process building are used for removing or fixing smearable contamination.

The next steps in placing the WSP in protective storage are to isolate the cells from the ventilation system and install HEPA-filtered vents to each independently isolated area. Contaminated filters in the ventilation system are removed using normal maintenance techniques.

All equipment, piping and other systems not needed during the interim care period are deactivated. All active plant systems (ventilation, electrical, water, etc.) are shut down. Only passive systems required for safety or surveillance remain. Intrusion alarms are installed and remote readouts for intrusion, fire and radiation alarms are provided. All utilities not needed during interim care are deactivated. Building entrances not required for surveillance and maintenance are sealed. After a final radiation survey of the facility, the building is sealed by welding exterior doors closed or by installing high security locks.

Details of procedures used to place the waste solidification plant in protective storage are presented in Appendix E.4.4, Volume 2.

\subsubsection{Protective Storage Activities in the Fuel Receiving and Storage Station}

The fuel receiving and storage station (FRSS) will generally undergo chemical and mechanical decontamination, equipment deactivation and isolation procedures similar to those in the main process building. Details of those steps are not repeated here, but considerations specific to the FRSS are discussed in this section.

The procedures followed during plant production operations when a leaking fuel bundle is received, and the continuous recirculation and deionization of 
the pool water during plant operation minimize the expected contamination levels in the FRSS. The contamination levels are expected to be low enough to allow decontamination by direct personnel contact. Most areas exposed to potential contamination are stainless steel that can generally be spot decontaminated. Concrete portions of the FRSS are expected to be essentially free of contamination.

Protective storage operations in the FRSS begin with draining and chemically decontaminating the pools. The pool water is deionized (using installed equipment, upgraded as necessary) to radioactivity levels that permit release to local water bodies, or vaporized out the plant stack. As the pools are drained, the walls, floor, and fuel storage racks are sprayed with water or steam and painted to fix residual contamination. The opening between the fue 1 transfer pool and the remote process cell is sealed as soon as it is exposed by draining the pool. Radioactive particulates that may have settled on the storage pool floor are removed with an underwater vacuum cleaner when about $2.0 \mathrm{~m}(6 \mathrm{ft})$ of water remain in the pool.

Equipment in the FRSS is deactivated using procedures similar to those outlined for the main process building. The deionization area is chemically decontaminated and isolated after removal of flammable deionization materials. The ventilation system is also decontaminated and sealed, and HEPA-filtered vents are installed. Final preparations for the interim care period include installing and/or upgrading radiation and fire alarms and automatic fire fighting equipment, sealing or installing high security locks on exterior doors, installing intrusion alarms, and performing a comprehensive radiation survey.

Details of the procedures for decontaminating and isolating the FRSS are given in Appendix E.4.5, Volume 2.

\subsubsection{Protective Storage of Auxiliary Facilities}

After the liquid waste storage facilities have been placed in protective storage, the auxiliary facilities providing services to these areas are decommissioned. The auxiliary facilities in operation at that time include the ventilation filter station, main plant stack and associated equipment and the radioactive laboratories. Protective storage procedures for each of these areas are outlined briefly below. 


\section{Ventilation Filter Station}

All filters are removed and the filter housing is washed with high pressure hot water sprayers. Intake and exhaust ductwork is sealed by welding. Contaminated blowers or other equipment are placed in the filter housing room. Noncontaminated equipment is deactivated. Safety systems to be operated during the interim care period are upgraded as necessary. Intrusion alarms and remote readout of safety systems are provided. Airlock doors to the filter housing are welded closed and HEPA-filtered vents are installed. Exterior doors are welded or secured with high security locks.

\section{- Stack and Associated Facilities}

The main plant stack is chemically decontaminated and capped and the intake duct is sealed by welding. Contaminated auxiliary equipment (nitric acid fractionator overhead vaporizing equipment) is removed and stored in an isolated portion of the facility. HEPA-filtered vents are provided for the stack, the ductwork between the stack and VFS, and the stack building. The access door to the stack building is secured with high security locks.

- Radioactive Laboratories

Filters are removed from the AFS and the station is decontaminated. A HEPA-filtered vent is installed for the laboratory area. Intrusion alarms are installed in the laboratory area and remote readout capabilities for fire and radiation alarms are added. All utilities not required during the period of interim care are deactivated. Laboratory building entrances not required for surveillance and maintenance are sealed.

\subsubsection{Interim Care Period}

The interim care period begins when protective storage activities have been complete. This period is characterized by surveillance and maintenance activities designed to assure that the facility remains in a condition that poses minimum risks to the public. The activities included in this phase are monitoring and maintenance of operating safety systems, inspection and maintenance of physical barriers, and performing a radiation and environmental monitoring program. A comprehensive inspection of the entire facility is 
performed annually by qualified professional personnel. Unusual or unsafe conditions detected during the surveillance program are corrected immediately.

The interim care period lasts until final dismantlement of the facility takes place. The length of this period will be determined from a cost-benefit analysis balancing the costs of surveillance and maintenance against the decreased dismantlement costs and land use values, or based on societal or regulatory issues. Radiation levels are expected to reduce approximately one order of magnitude in 100 years.

The surveillance and maintenance program is structured so that personnel inspect various portions of the facility on a routine basis. Radiation monitoring is done at each pre-established surveillance point at least quarterly. These checks are staggered so that the monitoring actually takes place over several days, distributed throughout the quarter. One day's surveillance activities consist of taking readings at several established surveillance points and taking some random smears and readings while proceeding from one surveillance point to the next. Preventive maintenance activities and routine equipment inspections are also distributed throughout the quarter. HEPAfiltered vents and physical barriers are inspected monthly and repaired as necessary. An abbreviated version of the environmental monitoring program conducted during plant operation is carried out. As experience is gained during the surveillance period, the frequency of the surveillance checks may be altered. Routine inspections of systems such as fire fighting equipment and fire alarms that were performed by outside experts during plant operation are continued during protective storage.

The fire alarms, radiation alarms and intrusion alarms operating in the facility during the interim care period are monitored continuously. Because the facility is not manned all the time, remote readout for these instruments is provided at a neighboring nuclear facility or local law enforcement or commercial security agency. The official in this area will summon assistance if an unusual situation is indicated by the alarms. Arrangements are made to assure that a person knowledgeable about the facility can be contacted at any time. 
Security during the surveillance and maintenance period is provided by several methods. The fence around the $0.12 \mathrm{~km}^{2}$ (30 acres) of the decommissioned facility provides the first line of security. It is maintained in good condition throughout the interim care period. Gates in the fence remain locked at all times. Building security is maintained by installed intrusion alarms and high security locks on exterior doors that have not been sealed. Arrangements are made for off-shift drive-by inspections of the site by a commerical security agency. Spot checks by local law enforcement personnel can also be expected.

\subsubsection{Final Dismantlement Following Protective Storage}

To obtain release of the site on an unrestricted basis, all hazardous amounts of radioactive materials must be removed. Dismantlement of the facility following the interim care period will be done using the techniques described in Section 7.3, with minor exceptions. Activities common to the dismantlement and protective storage modes are not repeated. Some steps required to place the facility in protective storage will need to be reversed. Table 7.4-2 summarizes these activities. A schedule for carrying out final dismantlement of the reference facility following protective storage is presented in Figure 7.4-3.

This study has not addressed deferred dismantlement in as detailed a manner as was done for dismantlement as the initial decommissioning mode. Technological or regulatory changes during the interim care period could change the way in which the facility is dismantled. Costs associated with deferred dismantlement are discussed in Section 7.8.

\subsection{LAYAWAY MODE}

The procedures presented in this section are used to place the reference Fuel Processing Plant in a condition that provides protection to the public and the environment from the residual radioactivity at the facility with a minimum initial expenditure. A minium of activities is used to place the facility in layaway. These activities include an overall facility cleanup and deactivation of equipment not required to be in operation during the interim care period. 


\section{TABLE 7.4-2. Previously Completed Activities and Additional Activities for Deferred Dismantlement Following Protective Storage}

\section{Main Process Building}

1. Chemically decontaminate internals of process equipment and piping

2. Chemically decontaminate cell walls and vessel externals

3. Decontaminate glove box

1. Remove entrance barriers to building, process cells, and other contaminated areas

2. Reactivate utilities

3. Reactivate cranes and manipulators

4. Install filters and reactivate ventilation system

\section{Liquid Waste Storage Area}

1. Flush heel from HLLW tanks and ILLW tank

1. Remove entrance barriers to building, diverter cel1, and hot area of WTEG

2. Chemically decontaminate off-gas equipment and piping and diverter cell in WTEG

2. Reactivate utilities

3. Install filters and reactivate ventilation system

4. Remove inorganic absorbent from waste tanks

\section{Waste Solidification Plant}

1. Solidify process wastes from chemical decontamination of process building and from flushings liquid waste tanks

2. Chemically decontaminate process equipment cell walls and vessel externals in WSP
1. Remove entrance barriers to buildings and cells

2. Reactivate utilities

3. Reactivate cranes and manipulators, and viewing windows

4. Install filters and reactivate ventilation system

Fuel Receiving and Storage Station

1. Deionize and drain storage pools

2. Decontaminate water treatment system
1. Remove entrance barriers to building

2. Reactivate utilities

3. Install filters and reactivate ventilation system

Auxiliary Facilities

1. Remove entrance barriers to buildings

2. Reactivate utilities

3. Uncap main stack and unseal ventilation ductwork

4. Install filters and reactivate AFS and VFS ventilation systems 


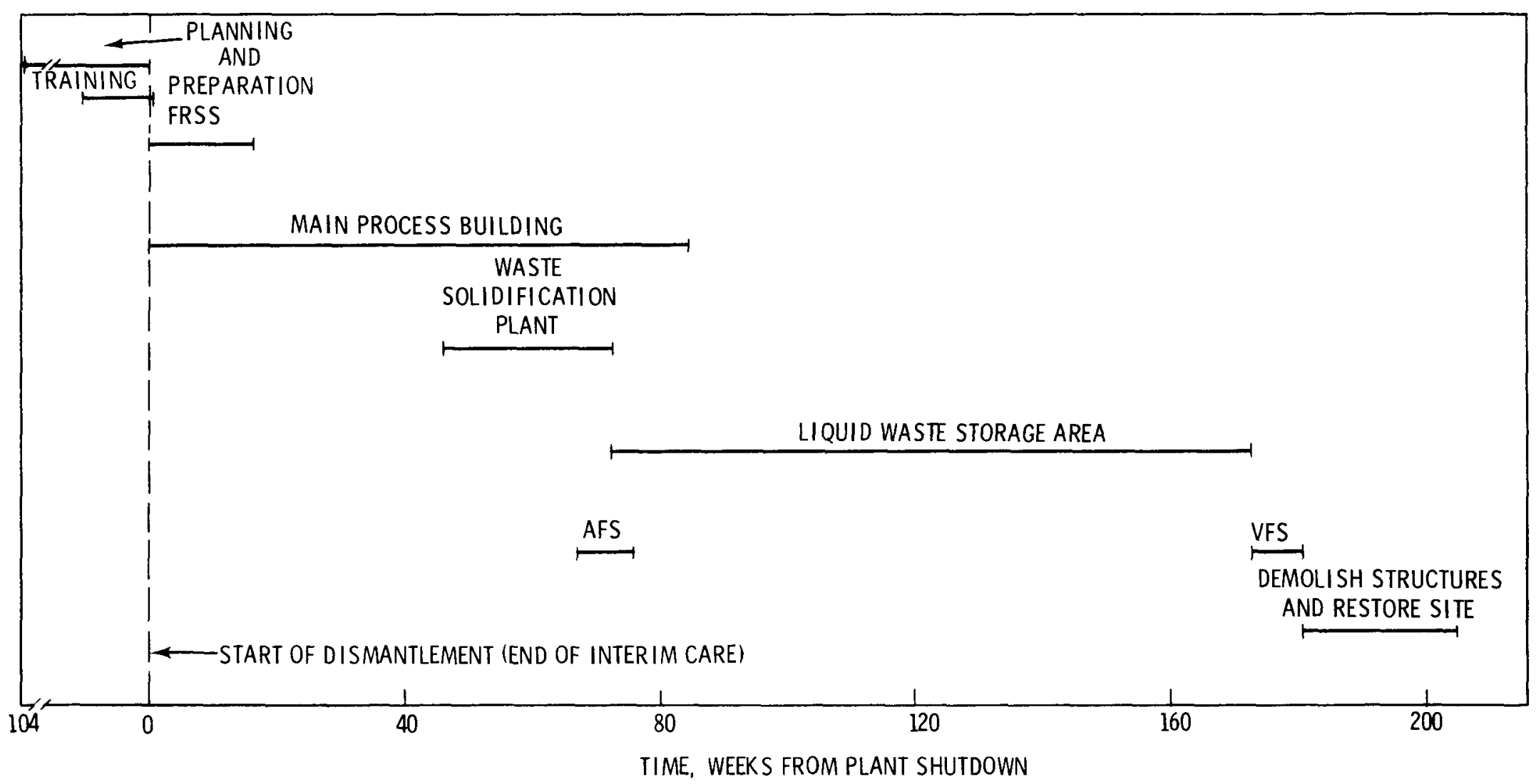

FIGURE 7.4-3. Sequence of Events for Deferred Dismantlement of the Reference Fuel Reprocessing Plant Following Protective Storage 
The final plant condition is one with most radioactivity present during plant operations removed, but with important quantities (thousands of curies) remaining. Building structural integrity and operation of the ventilation system are the primary radionuclide confinement mechanisms after layaway.

Activities at the site during the interim care period following layaway are limited to maintenance and monitoring of operating equipment, and facility and environmental radiation surveillance. The facility is manned on a continuous basis after layaway decommissioning to operate and monitor the condition of safety related systems. The outer perimeter site fence is maintained, and no unauthorized entry is permitted after the facility is placed in layaway. Detailed accounts of the post-layaway decommissioning status and interim care operations are kept and made part of the public record. These accounts are required when final dismantlement of the facility is performed.

\subsubsection{Overview of Layaway Activities}

For this study, the facility was considered to be divided into the same five sections as for the other decommissioning modes. These facility sections are:

- main process building

- liquid waste storage facility

- waste solidification plant (WSP)

- fuel receiving and storage station (FRSS)

- auxiliary areas

The layaway operations in each section of the facility are divided into the following five phases:

- planning and preparation

- chemical decontamination

- mechanical decontamination and fixing of residual contamination

- equipment deactivation

- final preparation for surveillance and maintenance.

Following these phases, the facility is placed in the interim care period until the facility is finally dismantled. 
Planning and preparation activities (as described in Section 7.1) are carried out during the final two years of plant operation. Chemical decontamination of the facility is performed to reduce radiation levels in the facility, and is done using the techniques described in Section 7.2.

A sequence of activities for placing the reference facility in layaway is shown in Figure 7.5-1. An outline of these activities is presented in Table 7.5-1. Portions of these activities in various sections of the facility may overlap and proceed concurrently. The activities in Table 7.5-1 are summarized below.

\subsubsection{Layaway Activities in the Main Process Building}

These operations begin with the chemical decontamination of the process cells. Next, radioactive material in accessible areas of the plant is removed. Contamination that cannot be readily removed is fixed in place by painting. A11 systems and equipment in the main process building that are not required during the interim care period are deactivated. All safety-related systems such as building ventilation, fire protection, and radiation monitoring equipment is inspected and placed in a condition that provides maximum reliability during the interim care period. Additional safety devices required for facility surveillance and security such as high security locks, barricades, and intrusion alarms are installed.

\subsubsection{Mechanical Decontamination and Fixing of Residual Contamination}

These operations begin with the completion of internal and external chemical decontamination of process equipment, cell walls and vessel externals. Following chemical decontamination, areas of the main process building outside the process cells are decontaminated to remove as much smearable contamination as practicable. Contamination that cannot readily be removed is fixed in place by the application of one coat each of two distinctively colored paints. Unnecessary noncontaminated equipment and materials are removed and inventories of flammable articles are reduced to minimum levels. A sequence of events for decontaminating and sealing glove boxes and hoods and the sample and analytical cells is presented in Appendix E.5.1, Volume 2. 


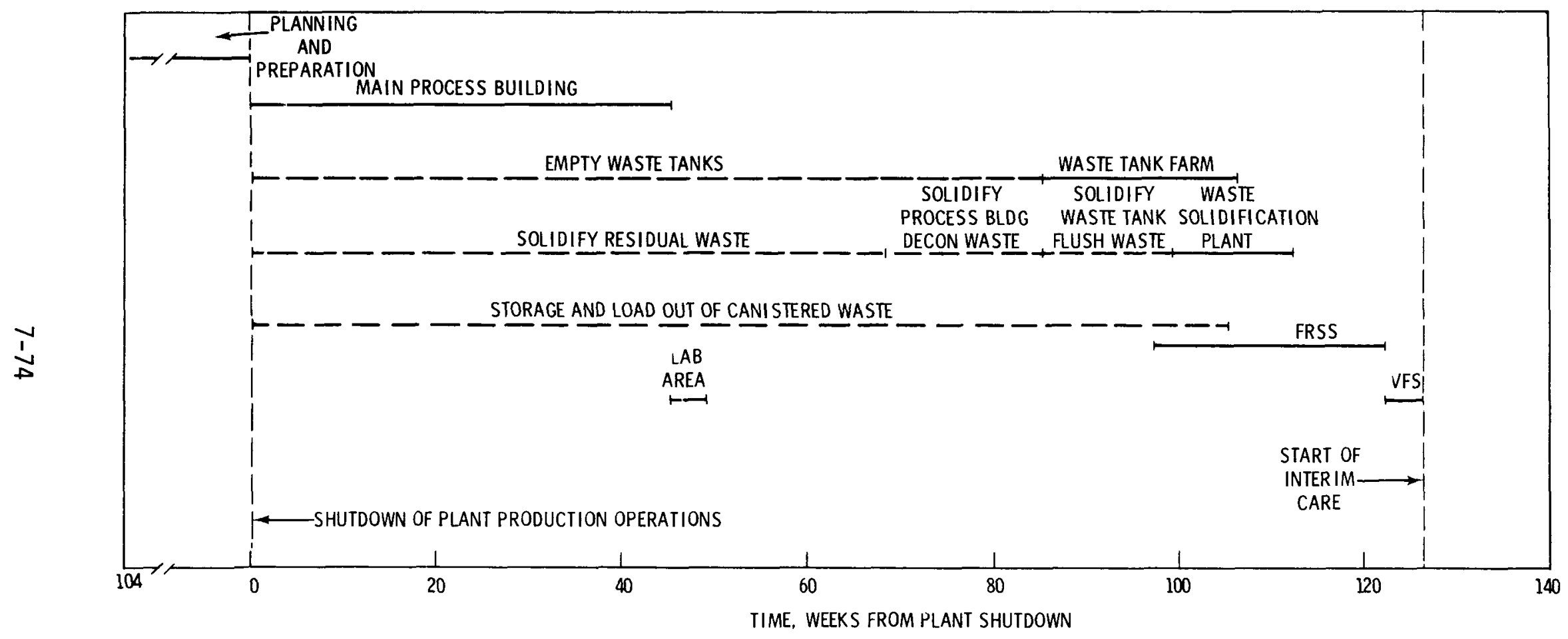

FIGURE 7.5-1. Sequence of Events for Placing the Reference Fuel Reprocessing Plant in Layaway 
TABLE 7.5-1. Outline of Layaway Activities (a)

131

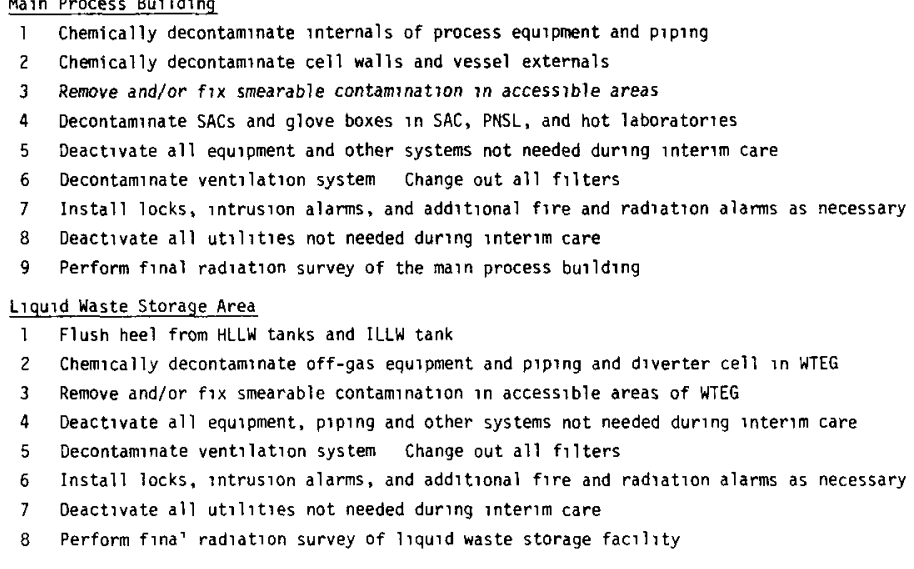

Waste Solidification Plant

1 Solidify process wastes from chemical decontamination of main process building and from flushing of liquid waste tanks

2 Chemically decontaminate cell walls and vessel externals

3 Solidify chemical decontamination solutions used above (This activity also alds in internal flushing of the processing equipment)

4 Drain can transfer aisle between the CDC and the FRSS

5 Disconnect electrical supply to furnaces and disable umbilical systems

6 Remove and/or fix smearable contamination in accessible areas

7 Deactivate all equipment, piping and other systems not needed during interim care

8 Decontaminate ventilation system Change out ail filters

9 Instail locks, intrusion alarms, and additional fire and radiation alarms as necessary

10 Deactivate all utilities not needed during interim care

11 Perform final radiation survey of WSP

\section{Fuei Receiving and Storage Station}

1 Man loadout station in FRSS

2 Delonize and empty storage pools

3 Deactivate and decontaminate water treatment system

4 Remove and/or fix smearable contamination in pooi area

5 Decontaminate fuel storage racks

6 Seal access between RPC and fuel transfer pool

7 Remove and/or fix smearable contamination in other areas and deactivate cranes

8 Decontamnate ventilation system Change out all filters

9 Instali locked, intrusion alarms, and addstional fire and radiation alarms as necessary

10 Deactivate all utilities not needed during interim care

11 Perform finai radiation survey of FRSS

Auxiliary Facilities

1 Replace filters in AFS

2 Install locks, intruder alarns and additional fire and radiation alarms in laboratory area as necessary

3 Deactivate all utilities in laboratory area not needed for interm care

4 Replace filters in VFS

5 Install locks, intrusion alarms and additional fire and radiation alarms in blower station building as necessary The areas to be decontaninated include the following

6 P1pe galleries (TPIG, LPIG FPIG,

7 Service concentrator gallery

8 Sample and analytical cells

9 Giove boxes in the analytical viewing and operating station (AvOS) and plutonium nitrate operating station (PNOS)

10 Glove boxes and hoods in the not laboratories

11 Hull monitor maintenance galiery

12 Viewing and operating stations (LVOS, GVOS TVDS)

14 Manipulator repair station

15 Cask loading station

(a) See Section 12 for defintions of abbreviations 
$-\infty$

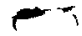


Decontamination methods used to prepare accessible areas of the facility for layaway are identical to those used for the protective storage mode and are not discussed in detail here. Briefly, they include simple "janitorial" techniques such as vacuuming, sweeping or scrubbing with cleaning agents, the use of acid-proof sponges soaked in decontamination solution, portable high pressure decontamination sprayers; and chipping, drilling and rock splitting, and jackhammering.

Areas that cannot be adequately decontaminated using these techniques or where contamination levels do not warrant the time and expense required for mechanical removal, are painted. The painting, comprised of at least one coat each of two distinctively colored paints, is to prevent the contamination from becoming airborne. Radiation warning signs are placed near the painted areas. The location and characteristics of each such area are noted in the permanent records of the layaway operation. Equipment in these areas that cannot be adequately decontaminated is removed and placed in the remote maintenance and scrap cel1 where it will remain during the interim care period.

The exhaust ductwork from the process cel1s, plutonium nitrate storage and loadout area and the sample and analytical cells is chemically decontaminated. Decontamination procedures used during plant operations are followed. It is expected that the decontamination will consist primarily of hot water flushes to remove dirt and grease. Chemical solutions may be used if there is significant buildup of contamination in the ductwork. All exhaust ductwork is stainless steel and is not harmed by conventional decontamination solutions such as nitric acid. The roughing and first stage of HEPA filters in the process cells, PNSL, and SAC exhaust ductwork are replaced during these operations. Subsequent stages of HEPA filters are replaced unless replacement is determined to be unwarranted.

\subsubsection{Equipment Deactivation}

The equipment and systems in the facility that are not required to be in operation after the decommissioning period are placed in a condition that provides maximum safety and requires minimum maintenance. Whenever possible, equipment is left in a condition that permits salvage or use during final dismantlement at a later date. Equipment deactivation procedures are coordinated 
with facility decontamination operations. In some areas decontamination must be carried out before equipment deactivation, while in other areas the opposite approach may be necessary.

The particular method used to deactivate each system or piece of equipment is identified during the planning phase. In general, all systems not necessary to prevent the spread of contamimation are deactivated. (See Section 7.5.2.3 for systems retained.) All equipment, valves, circuit breakers, etc., are tagged when deactivated. This tag identifies the piece of equipment, the system it is in and its layaway condition.

The first step in equipment deactivation is a safety audit of all pumps and pipes used for organic materials or hazardous chemicals to ensure that all flammable and other dangerous materials have been removed. Electrical service is disconnected from all pumps not required to be in operation during the interin care period. All pipes (except sanitary and fire fighting water) that penetrate the exterior walls of the building are blanked.

Systems inside the main process building are deactivated by a variety of methods. Most systems are isolated using installed valves with handles removed. Pipes that had previously contained contaminated materials or hazardous chemicals are blanked. Other systems are drained and left open to the atmosphere. A fresh coating of fire retardant material is applied to all electrical cable runs. All cranes are disabled by removal of their circuit breakers to prevent their unauthorized use during the interim care period. Other electrical equipment, including instruments, that should not be operated during the interim care period is disabled in a similar manner.

\subsubsection{Systems Retained in Operation}

The systems discussed below will remain in operation throughout the interim care period following layaway. These systems, in combination with inherent facility structural integrity, provide means for minimizing the release of hazardous material to the environment after layaway. The equipment in these systems is inspected and renovated to assure maximum equipment reliability before the interim care phase begins. 


\section{- Ventilation}

The ventilation system and most ventilation equipment will remain intact and in operation. Normal ventilation pathways are maintained. Ventilation flow rates are reduced to the lowest levels that will maintain these pathways. Heating and cooling systems operate at reduced levels. Cooling is used primarily for humidity control, and heating is used only to prevent freezing or other equipment damage.

- Fire Protection

A11 fire fighting and fire detection systems, including automatic fire fighting equipment remains in operation.

- Radiation Monitors

Radiation monitors and alarms remain in operation at strategic locations throughout the main process building. The location of some devices may be changed and some additional devices may be installed to assure that important areas are adequately covered. Effluent monitoring equipment and environmental monitoring systems are also maintained in operation.

\section{- Emergency Electrical System}

The emergency electrical system is maintained to run the ventilation, radiation monitoring and alarm, and fire protection systems in the event of the loss of normal electrical power. Switchboards are aligned so that no electrical power is fed to deactivated systems.

\subsubsection{Final Preparation for Surveillance and Maintainance}

When all other layaway activities in the main process building have been completed, the final layaway operations outlined below are carried out. An intrusion alarm system is installed to detect violation of the outer perimeter fence and the presence of unauthroized personnel in the building during the surveillance and maintenance period. High security locks are installed on all exterior doors and on 111 interior doors into contaminated areas, (or areas that provide access to contaminated regions). The final operation in this phase is to conduct a comprehensive radiation survey of the facility to establish a reference for surveys during the interim care period and to designate the survey points to be used during the surveillance period. 


\subsubsection{Layaway Activities in the Liquid Waste Tank Farm}

The liquid waste storage facility is prepared for layaway after the inventory of liquid wastes and decontamination solutions has been solidified. For this study, it was assumed that the equivalent of one full tank of highlevel waste $\left(1.14 \times 10^{6} \mathrm{l}\right)$ and one-half tank of intermediate-level waste are present at shutdown of the facility.

The liquid waste storage tanks are decommissioned first, followed by the waste tank equipment gallery.

All piping and ventilation connections between the liquid waste storage facility and the main process building are blanked when layaway operations in the tank farm begin. This necessitates rerouting the waste tank off-gas system and the waste tank cell vent system to the waste solidification facility. The WTEG vent system is routed directly to the VFS. After all the liquid waste storage facilities have been placed in layaway, the water seal on the tank tops is allowed to dry out and the pipe tunnel between the tank farm and the uranium product cell is reopened. This allows the waste tanks and waste tank cells to vent through the main process building ventilation system during the interim care period.

\subsubsection{Layaway Procedures for the High Level Liquid Waste Storage Tanks}

The high level liquid waste (HLLW) tanks cannot be pumped down completely by using the existing pump-out jets. A heel of approximately $11,000 \&$ of solution is left in each tank when pump-out is completed. Radioactivity levels expected in the tanks at the time of plant shutdown are presented in Section 5.4 .

The radioactivity level in each of the tanks is reduced by four successive flushes with 38,000 \& $(10,000 \mathrm{gal})$ each of nitric acid solution. The tank is pumped down following each dilution and the used flush solutions are transferred to the waste solidification plant for processing. Fifty percent nitric acid solutions are used for the first two flushes. The nitric acid concentration in the final flushes is adjusted so that the residual solution in the tank after the final pumpdown is about $1 \mathrm{M}$ nitric acid. This concentration is selected because it minimizes the corrosion of the stainless stee] 
tank while maintaining a sufficiently high acidity to minimize precipitation of the residual fission products and actinides. Although chemical decontamination of the tank internals and tank vault liners would be desirable, no equipment is built into the tank vaults to accomplish this task. Installation of this equipment would require an extensive effort and is considered beyond the scope of a layaway operation.

During the layaway decommissioning of the waste tanks and during the interim care period, a small flow of air is maintained through the tank sparging and off-gas system. The air flow is sufficient to prevent the accumulation of hydrogen or radioactive gases in the tanks. The air sparge and tank off-gas equipment in the WTEGs are thus maintained in operation throughout the interim care period. The residual liquid in the tanks is sampled periodically during the interim care phase and additional solutions are added as necessary to maintain the 1 M nitric acid concentration.

\subsubsection{Layaway Procedures for the Intermediate Level Liquid Waste Storage Tanks}

Radiation levels in the intermediate level liquid waste tanks are expected to be about 1000 times lower than in the high level tanks. Four flushes of the tank with 38,000 \& $(10,000 \mathrm{gal})$ of $50 \%$ nitric acid reduce the radioactivity levels in the tanks to modest levels. The intermediate level tank design permits the introduction of long shaft pump into the tank through an access column on the tank top. This pump can be used to remove most of the solution that is left in the tank by the pump-out jets. A nominal air flow is also maintained through the intermediate level tanks during the interim care period. The operational status of this system requires periodic monitoring.

\subsubsection{Layaway Procedures for the Waste Tank Equipment Gal Tery}

Layaway of the WTEG uses techniques similar to those employed in the layaway of the main process building. The WTEG is divided into areas designated radioactively hot, intermediate or cold. Activities in the nonradioactive areas are limited to deactivation of equipment not required to be in service during the interim care period. This equipment is not expected to be 
radioactively contaminated. Radioactively contaminated areas are chemically decontaminated using techniques similar to those used in the process cells.

Equipment in the intermediate areas that might have come into contact with radioactive solutions are also flushed internally. Contaminated areas of concrete or external surfaces of equipment in the intermediate areas are decontaminated using the techniques described in Section 7.5.2.1. Areas of radioactive concrete that cannot be decontaminated satisfactorily are removed and the hole grouted over if it represents a safety hazard. Contamination that cannot be removed is fixed in place by application of at least one coat each of two distinctively-colored paints. Equipment that cannot be decontaminated satisfactorily is removed and placed in the RMSC of the main process building.

Pipes and pumps are drained and blanked or isolated as appropriate. All pipes that penetrate the exterior of the WTEG are blanked except for sanitary and fire fighting water. Ventilation filters are changed as necessary using existing procedures. Electrical equipment that should not be operated during the surveillance and maintenance period for safety reasons is disabled by removal of circuit breakers. Other equipment is deactivated using techniques described previously for the main process building.

The building and waste tank ventilation systems and radiation monitoring and fire protection systems are refurbished as necessary. Readout of the status of all operating and safety systems is provided in the main process building control room. Locks, intrusion alarms and additional fire and radiation alarms are added as needed. After deactivating all utilities not needed during the interim care period, a final radiation survey is made of the facility.

\subsubsection{Layaway Activities in the Waste Solidification Plant (WSP)}

All process wastes generated in chemically decontaminating the main process building and flushing the waste tanks are solidified before the WSP is prepared for layaway. After solidification of these wastes has been completed, process equipment is chemically decontaminated both internally and externally along with the cell walls. Chemical decontamination solutions generated during 
this operation are solidified by the existing in-plant equipment. Processing of the decontamination solutions serves as an additional internal flush of waste solidification equipment.

The can transfer aisle connecting the canister decontamination cell with the fuel recieving and storage station is drained after all canisters have been transferred out. Electrical services to the furnaces in the WVC are disconnected and the umbilical systems are disabled. Smearable contamination in accessible areas is removed or fixed using the techniques described for the main process building.

A11 equipment, piping and other systems not needed during interim care are deactivated. Facility ventilation and utility systems along with the fire protection system remain activated. The ventilation system is decontaminated using techniques identical to those used in the main process building. All filters are changed out using standard operating procedures.

Final steps in placing the facility in layaway include the installation of locks, intrusion alarms, and additional fire and radiation alarms as necessary. All utilities not needed during the interim care period are deactivated. Finally, a radiation survey of the facility is performed.

7.5.5 Layaway Activities in the Fuel Receiving and Storage Station

The fuel receiving and storage station (FRSS) generally undergoes chemical and mechanical decontamination and equipment deactivation procedures similar to those in the main process building. Details of those steps are not repeated here, but considerations specific to the FRSS are discussed in this section.

Layaway operations in the FRSS begin with the draining and chemical decontamination of the pools. The pool recirculation, deionization and filtration system is operated until the radioactivity in the pool water is reduced to a level that will permit release of the water to the environment, consistent with the principles of ALARA. As much of the pool water as possible is vaporized in the acid fractionator overhead vaporizer and released to the atmosphere through the main plant stack. Compliance with Federal and local water and air quality standards is determined by analysis of the pool water 
before it is released. Deionization of the water is expected to require approximately 100 days using the installed deionization equipment. Additional equipment may be installed if necessary to reduce the radioactivity to the desired levels.

Any pool water not vaporized is drained to the water reservoir and subsequently released to local water bodies. As the pools are drained, the exposed surfaces are washed with water or steam and painted with a nonflammable water-based paint. The opening between the fuel transfer pool and the remote process cell is sealed with a stainless steel plate as soon as it is exposed. Gasket material is used to provide an air-tight seal.

When about $2.0 \mathrm{~m}$ of water remains in the pools, radioactive particles are removed from the pool with an underwater vacuum cleaner. The particles are collected in filters placed in the vacuum discharge. The remainder of the pool water is drained and the pool floor is decontaminated with high pressure sprayers and painted.

Equipment in the pools is surveyed and any contamination is removed with high pressure sprays. Nonremovable contamination is fixed by painting with at least one coat each of two distinctively colored paints. Equipment that cannot be effectively decontaminated or coated is removed to the RMSC for storage.

Ion exchange beds, recirculation pumps, and water filters are cleaned and any flammable deionization materials are packaged and transported to an offsite disposal area. The remaining contaminated deionization equipment is placed in the RMSC. The FRSS cranes and any other equipment not required during the surveillance phase are deactivated. The radiation monitoring system, fire alarm system, and ventilation system are upgraded as necessary. High security locks are installed on all exterior doors and cell interior doors leading to contaminated areas. Intrusion alarms are installed at selected locations. Readouts for all alarm systems are provided in the main process building control room. A final radiation survey is made of the FRSS.

\subsubsection{Layaway Activities in the Auxiliary Facilities}

Layaway activities in the auxiliary facilities are minimal. Filters are replaced in the AFS and VSF using standard maintenance techniques. All 
atilities in the laboratory area that are not needed during the interim care period are deactivated. Locks, intrusion alarms, and additional fire and radiation alarms are installed in the laboratory area and blower station building as needed. Remote readout to the main process building control room is provided.

\subsubsection{Interim Care Period}

Following completion of layaway activities, the facility is placed in a period of surveillance and maintenance designed to assure that the facility remains in a condition that poses minimum risks to the public. This phase includes routine inspections, preventive and corrective maintenance on operating equipment and a regular program of radiation, effluent, and environmental monitoring. The status of all safety-related equipment is monitored continually during the interim care period. In addition to these routine tasks, a comprehensive inspection of the entire facility is performed annually by qualified personnel. Any unusal or unsafe condition detected during the surveillance program is corrected immediately.

The status of operating systems must be monitored continuously during the interim care period. The main process building control room is manned on all shifts for this purpose. Instrumentation to monitor all safety- and securityrelated equipment in the facility is installed and maintained at a central location in the control room. Normal operating conditions and alarms for ventilation failure, fire, abnormal radiation, intrusion and loss of offsite electrical power are monitored, as well as the status of equipment in the WTEG. The operator will take appropriate corrective action if possible and summon assistance if any unusual situation arises.

The surveillance and maintenance program is structured so that personnel are in various portions of the facility on a routine basis. Radiation monitoring is done at each pre-established surveillance point at least once each month. These checks are scheduled so that the monitoring actually takes place over several days, distributed throughout the month. One day's surveillance activities consist of taking radiation readings at several predetermined surveillance points. Some random smears and radiation readings are also 
taken. Preventive maintenance activities and routine equipment inspections particular systems are determined during the planning phase after consideration of the system's operating history.

As experience is gained during the interim care period, the frequency of the surveillance checks may be altered. Routine inspections of systems such as fire fighting equipment and fire alarms continue during layaway. Ventilation filters are inspected at regular intervals and replaced using existing procedures.

In addition to the periodic radiation monitoring program described above, automatic radiation detection equipment is operated continuously at various points in the facility to detect unusual occurrences. Effluent monitoring systems are also in continuous operation. Readout for these monitors is provided in the main process building control room. An environmental monitoring program similar to the one used during facility operation is also carried out.

Security during the interim care period is provided by several methods. The site boundary fence provides the first 1 ine of security. It is maintained in good condition throughout the interim care period with a security guard stationed at the main site entrance during regular working hours. Gates at this entrance are locked when the security guard is not present. A11 other entrances remain locked at all times. Building security is maintained by intrusion alarms and high security locks on all exterior doors and on all interior doors leading to contaminated areas. Arrangements are made for offshift drive-by inspections of the site by a commercial security agency. Periodic checks by local law-enforcement personnel can also be expected.

The interim care period will continue until final dismantlement of the facility takes place. The duration of this interim period for both protective storage and layaway modes will depend on a number of factors. The decision making process for final dismantlement was discussed under the protective storage mode and will not be repeated here.

\subsubsection{Final Dismantlement Following Layaway}

To release the site on an unrestricted basis, all radioactive material above unrestricted use limits must be removed. Dismantlement of the 
facility following layaway will be carried out using the techniques described in Section 7.3, with minor exceptions. Activities common to both the dismantlement and layaway modes will not be repeated. Some steps required to place the facility in layaway will need to be reversed. Table 7.5-2 summarizes these activities. A sequence of events for final dismantlement of the reference facility following layaway is presented in Figure 7.5-2.

\section{TABLE 7.5-2. Previously Completed Activities and Additional Activities for Deferred Dismantlement Following Layaway}

Previously Completed Activities

Additional Activities

Main Process Building

1. Chemically decontaminate inter nals of process equipment and

1. Reactivate utilities piping.

2. Chemically decontaminate cell walls and vessel externals.

2. Reactivate some systems taken out of services during layaway

3. Decontaminate glove boxes.

\section{Liquid Waste Storage Area}

1. Flush heel from HLLW tanks and ILLW tanks.

1. Reactivate utilities

2. Chemically decontaminate offgas equipment and piping, and diverter cell in WTEG.

\section{Waste Solidification Plant}

1. Solidify process wastes from chemical decontamination of

1. Reactivate utilities main process building and from flushing liquid waste tanks.

2. Chemically decontaminate process equipment cell walls, and vessel externals in WSP.

2. Reactivate some systems taken out of service during layaway.

\section{Fuel Receiving and Storage Station}

1. Deionize and drain storage

1. Reactivate utilities pools.

2. Decontaminate water treatment system.

Auxiliary Facilities

1. Reactivate utilities 


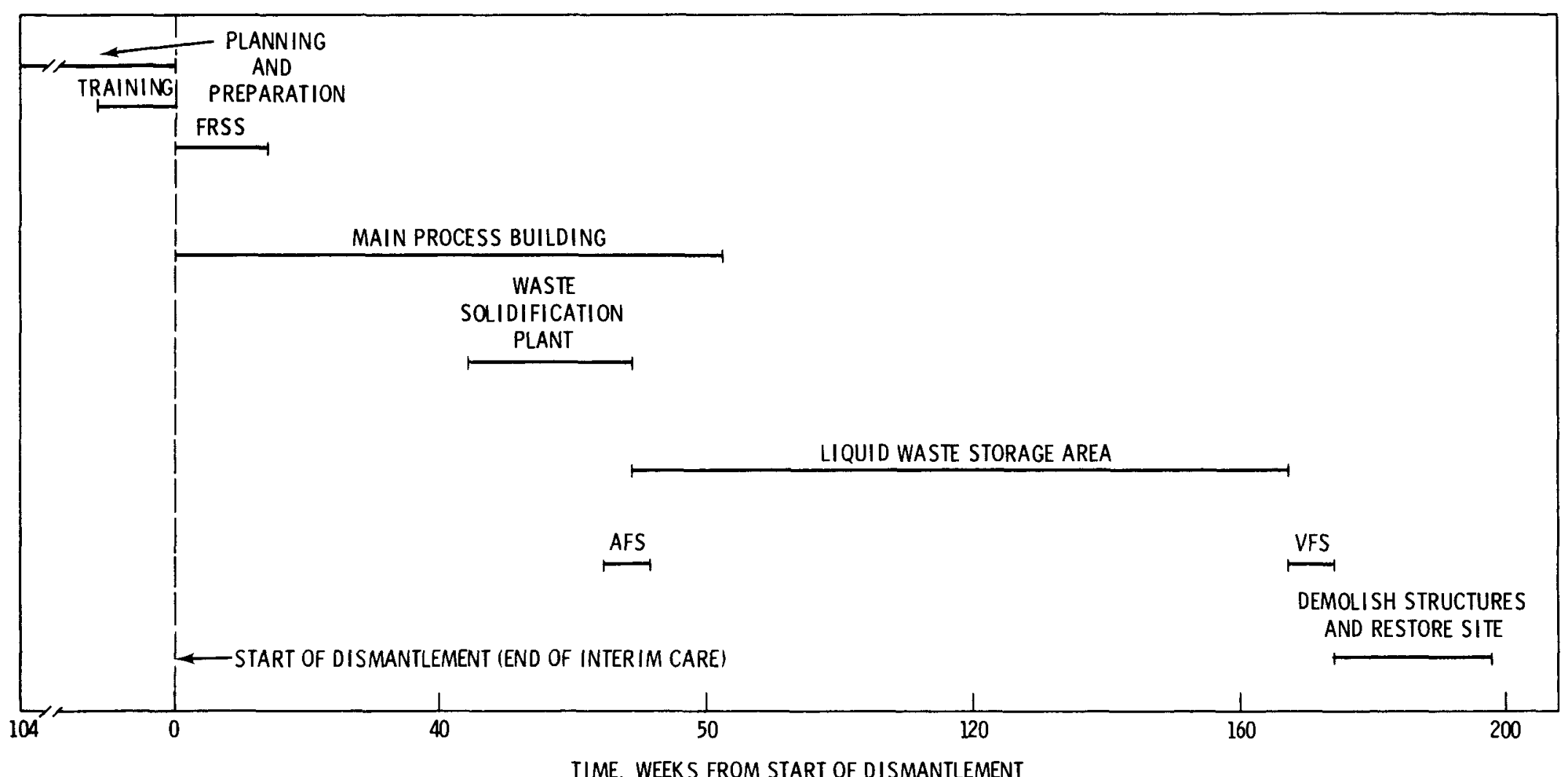

FIGURE 7.5-2. Sequence of Events for Deferred Dismantlement of the Reference Fuel Reprocessing Plant Following Layaway 
Costs associated with deferred dismantlement following layaway are discussed in Section 7.8 .

\subsection{DECOMMISSIONING WASTES AND WASTE DISPOSAL}

Large quantities of radioactive wastes are generated during the dismantlement of an FRP. Smaller amounts of wastes are generated during layaway and protective storage activities. These wastes must be packaged and shipped offsite for disposal.

Wastes generated during dismantlement of the FRP include:

- Solidified liquids from chemical decontamination activities. (Chemical decontamination liquids are processed through the waste solidification plant prior to the dismantlement of that facility.)

- Concrete rubble from the mechanical decontamination of process cells, fuel storage pools, waste tank vaults and other work areas.

- Protective stainless steel liners removed from the floors and walls of high contamination areas.

- Contaminated process vessels, equipment and piping. (The tank internals from the high-level liquid waste (HLLW) and intermediate level liquid waste (ILLW) tanks are included in this category.)

- Stainless steel sections of HLLW and ILLW tank walls.

- Spent fuel storage racks from the fuel storage pools.

- HEPA and roughing filters from off-gas and building ventilation systems.

- Glove boxes.

- Sections of ventilation ductwork and the main stack.

- Combustible and noncombustible trash (protective clothing, contaminated tools, paper, plastic, metal scrap, etc.).

The wastes generated during layaway and protective storage include the same solidified decontamination solutions and ventilation filters as during dismantlement, as well as smaller volumes of radioactive trash. 
Decommissioning wastes are categorized as transuranic-contaminated (TRU) and non-TRU wastes for disposal purposes. TRU wastes are shipped by rail to a Federal deep geologic repository. Non-TRU wastes are shipped by truck to a shallow land burial ground.

NRC has proposed adoption of a rule requiring that a11 wastes contaminated with more than 10 nanoci of transuranic elements per gram of waste be classified as TRU wastes. ${ }^{(5)}$ For this study, all wastes originating in portions of the plan with significant potential for transuranic contamination are assumed to be TRU wastes. Other wastes are assumed to be non-TRU. Table 7.6-1 1ists the locations in the plant where TRU and non-TRU wastes are assumed to originate.

For this study, TRU wastes are further categorized as low-level, intermediate-level, or high-level, depending on the radiation level from the waste. The solidified liquid wastes are generally sufficiently radioactive to generate moderate amounts of heat from radioactive decay, and are assumed to be high-level TRU waste. Equipment with TRU contamination that is also expected to have significant radiation (but with negligible internal heat generation rates) after chemical decontamination was designated as intermediateleve TRU wastes. Most of these wastes originate in the remote process cell or the high level cell in the main process building and the waste vitrification cell in the waste solidification plant. Ventilation filters from these areas were also assumed to be intermediate-level TRU wastes. All other TRU wastes and all non-TRU wastes were assumed to be low-level.

Under the proposed NRC rule, ${ }^{(5)}$ commercially generated wastes contaminated with transuranic elements must be shipped to Federal repositories for interim storage or permanent disposal. Fire safety requirements at a repository are assumed to require that all material accepted for disposal be packaged in nonflammable containers. For this study it is assumed that TRU wastes with low external radiation levels are packaged in steel boxes and $210-\ell$ drums which are placed inside $2.44 \mathrm{~m} \times 2.44 \mathrm{~m} \times 6.10 \mathrm{~m}$ steel cargo containers. Two cargo containers are shipped in an ATMX rail car $(6,7)$ These assumptions are consistent with current and anticipated future practice in the handling of TRU wastes by 1 icensees and prime contractors of the Energy Research and Development Administration. ${ }^{(8)}$ Approximately $10 \%$ of the contaminated equipment and 
TABLE 7.6-1. Assumed Origins of TRU and non-TRU Decommissioning Wastes

TRU Waste Non-TRU Waste

Process Building

RPC

RMSC

HLC

HILC

ILC

$x$

UPC

$x$

PPC

$x$

PNSL

SAC

$x$

$x$

$x$

$x$

CEMG

$x$

FN

$x$

CERS

$x$

EMS

HTG/PEG

$x$

$x$

Piping and Instrument Galleries

Viewing and Operating Stations

Laboratory Area

Other Aisles, Areas and Stations

$x$

$x$

$x$

$x$

$x$

Liquid Waste Storage Facilities

$\begin{array}{lc}\text { WTEG - Hot Area } & x \\ \text { WTEG - Other Areas } & \\ \text { WTDC } & \mathrm{X} \\ \text { HLLW Tanks } & \mathrm{X} \\ \text { ILLW Tanks } & \mathrm{X} \\ \text { Pipe Trenches } & \mathrm{X} \\ \text { Waste Solidification Plant } & \mathrm{X}\end{array}$

Fuel Receiving and Storage Station

$x$

Auxiliary Facilities

$x$

$x$

$x$

$x$

$x$

$x$

$x$

X

x

$x$

$x$

$x$


$20 \%$ of the HEPA filters resulting from dismantlement of the FRP require shield ing during transportation. These wastes are assumed to be packaged in $76 \mathrm{~cm}$ diameter by $3.05 \mathrm{~m}$ long cylindrical steel canisters and shipped to the geologic disposal repository in casks with 10 to $15 \mathrm{~cm}$ of lead shielding. These casks would be similar to rail casks currently licensed for the shipment of spent fuel, except that auxiliary cooling would not be required.

Solidified decontamination liquids are assumed to be treated and packaged according to procedures used for the solidification of high-level liquid production wastes at the waste solidification plant. The stainless steel canisters used for packaging these wastes are assumed to be $30 \mathrm{~cm}$ in diameter by $3.05 \mathrm{~m}$ long. Nine canisters would be transported in one load of a specially designed rail cask. (9)

Special train service is assumed to be required for all rail shipments to a Federal repository. Each train includes four cars carrying decommissioning wastes. The issue of the use of special trains for carriage of radioactive material has not yet been resolved, thus this assumption results in a conservatively high estimate of transportation costs.

Low level, nontransuranic wastes are transported to shallow land burial grounds for disposal. Commercial facilities in current use in the United States for near-surface burial of radioactive wastes do not have rail spurs. Therefore, all shipments of decommissioning wastes to these facilities are assumed to be made by truck.

Low-level, non-TRU wastes are packaged for disposal in containers such as steel or plywood boxes or 210- $\ell$ drums. Exceptions include the main stack and the ventilation duct from the blower station to the main stack. These items are sectioned and sealed and the sections are transported on low-boy trailers. Most packaged non-TRU waste shipments will qualify as low specific activity (LSA) material $(10)$ and can be shipped in an unshielded, exclusive-use, closed van. Shielding casks carried on low-boy trailers are used for waste containers with surface dose rates exceeding $200 \mathrm{mR} / \mathrm{hr}$. 
Packaging and shipping information for wastes generated in the dismantlement of a FRP is summarized in Table 7.6-2 for TRU wastes and in Table 7.6-3 for non-TRU wastes. Data on which the tables are based is presented in Appendix E.6. For protective storage and layaway operations, only solidified decontamination liquids, HEPA and roughing filters, and radioactive trash are assumed to require transportation to a disposal site. Waste volumes for filters and solidified decontamination liquids are assumed to be the same as for the dismantlement mode. Radioactive trash volumes are estimated to be $50 \%$ of the amount shown for dismantlement.

Shipment distances assumed for this study are $2400 \mathrm{~km}$ (1500 mi) for the transport of TRU waste to a Federal repository and $800 \mathrm{~km}$ (500 $\mathrm{mi}$ ) for the transport of non-TRU waste to a commerical burial ground. 


\section{TABLE 7.6-2. Packaging and Shipping Information for TRU Wastes Generated from}

Dismantlement of the Reference Fuel Reprocessing Plant

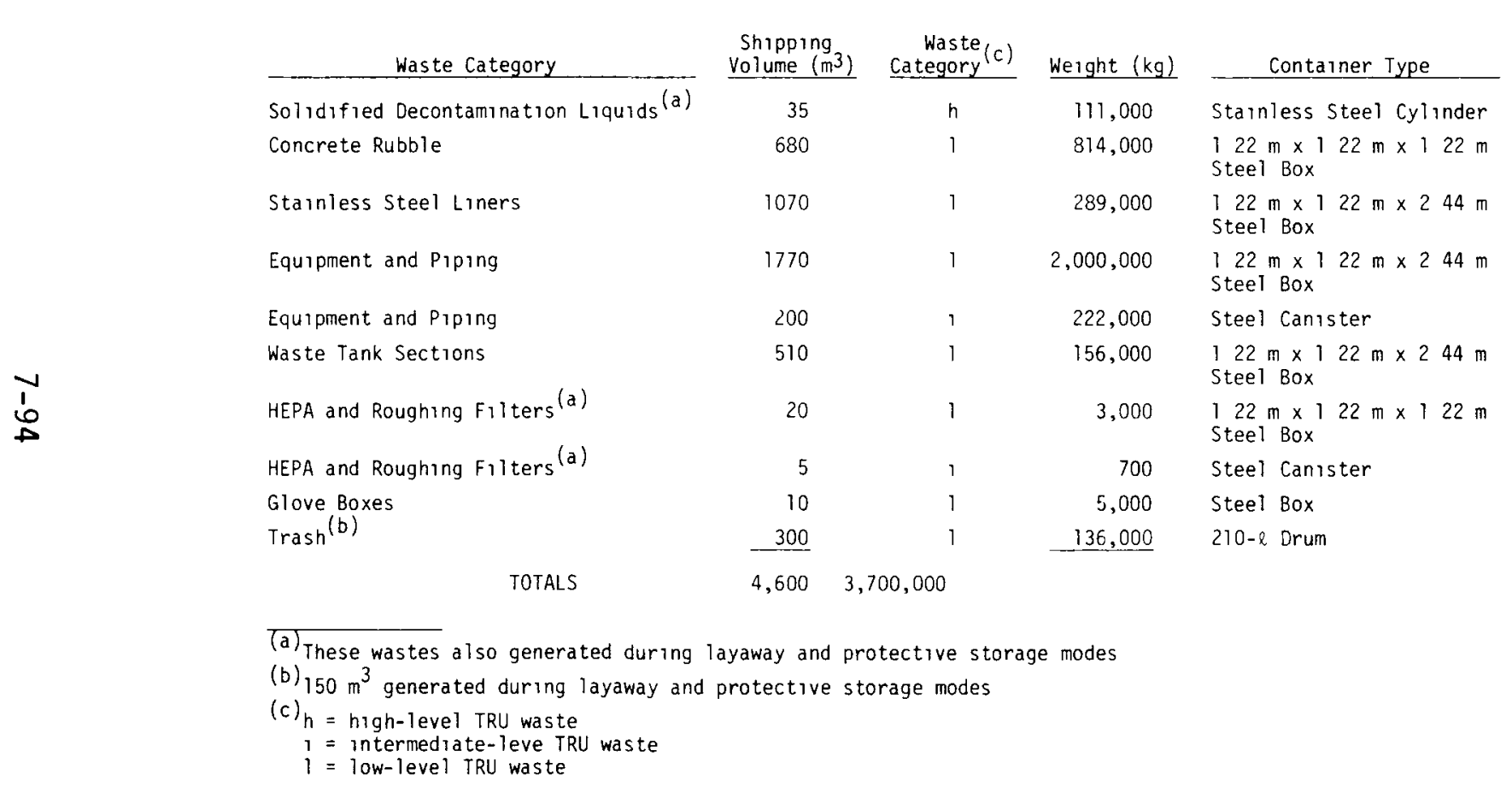

\begin{tabular}{ccc}
$\begin{array}{c}\text { Number } \\
\text { of } \\
\text { of } \\
\text { Containers }\end{array}$ & $\begin{array}{c}\text { Containers per } \\
\text { Rail Car } \\
\text { Shipment }\end{array}$ & $\begin{array}{c}\text { Number of } \\
\text { Ra11 Car } \\
\text { Shipments }\end{array}$ \\
\cline { 1 - 2 } 195 & 9 & 22 \\
374 & 20 & 19 \\
296 & 16 & 19 \\
488 & 12 & 41 \\
174 & 3 & 58 \\
141 & 16 & 9 \\
10 & 20 & 05 \\
6 & 3 & 2 \\
6 & 20 & 05 \\
$\underline{1,500}$ & 144 & $\underline{11}$ \\
3,200 & & 180
\end{tabular}




\section{TABLE 7.6-3. Packaging and Shipping Information for Non-TRU Wastes Generated from Dismantlement of the Reference Fuel Reprocessing Plant}

TABLE 7.6-3. Packaging and Shipping Information for Non-TRU Wastes Generated from Dismantlement of the Reference FRP

\begin{tabular}{|c|c|c|c|c|c|c|}
\hline Waste Category & $\begin{array}{l}\text { Shipping } \\
\text { Volume }\left(\mathrm{m}^{3}\right)\end{array}$ & Weight $(\mathrm{kg})$ & Container Type & $\begin{array}{l}\text { Number of } \\
\text { Containers }\end{array}$ & $\begin{array}{l}\text { Containers } \\
\text { Per Truck } \\
\text { Shipment }\end{array}$ & $\begin{array}{l}\text { Number of } \\
\text { Truck } \\
\text { Shipments } \\
\end{array}$ \\
\hline Concrete Rubble & 850 & $1,020,000$ & $\begin{array}{l}1.22 \mathrm{~m} \times 1.22 \mathrm{~m} \times 1.22 \mathrm{~m} \\
\text { Steel Box }\end{array}$ & 469 & 8 & 59 \\
\hline Stainless Steel Liners & 450 & 109,000 & $\begin{array}{l}1.22 \mathrm{~m} \times 1.22 \mathrm{~m} \times 2.44 \mathrm{~m} \\
\text { Steel Box }\end{array}$ & 124 & 12 & 10 \\
\hline Equipment and Piping & 800 & 886,000 & $\begin{array}{l}1.22 \mathrm{~m} \times 1.22 \mathrm{~m} \times 2.44 \mathrm{~m} \\
\text { Steel Box }\end{array}$ & 220 & 5 & 44 \\
\hline Fuel Storage Racks & 680 & 148,000 & Plywood Box & 120 & 6 & 20 \\
\hline HEPA and Roughing Filters $(a)$ & 30 & 5000 & Plywood Box & 46 & 46 & 1 \\
\hline Glove Boxes & 15 & 12,000 & Plywood Box & 15 & 15 & 1 \\
\hline $\operatorname{Trash}^{(b)}$ & 300 & 136,000 & $210-\ell$ Drum & 1500 & 72 & 21 \\
\hline TOTALS & 3100 & $2,300,000$ & & 2500 & & 160 \\
\hline
\end{tabular}

Ta) These wastes also generated during layaway and protective storage modes.

(b) $150 \mathrm{~m}^{3}$ generated during layaway and protective storage modes. 


\subsection{DECOMMISSIONING MANPOWER REQUIREMENTS}

Estimates were developed of the work force required to plan and execute the decommissioning activities described in Sections 7.1 through 7.5. The decommissioning work force is described in three parts: 1) the decommissioning support staff that plans, supervises and provides supporting services for the decommissioning activities, 2) the decommissioning workers who perform the actual decommissioning activities, and 3) the personnel that perform the maintenance and surveillance activities during the interim care periods following layaway and protective storage. These estimates, which were used to calculate manpower costs and occupational radiation doses, are presented in the remainder of this section.

\subsubsection{Support Staff Requirements}

Support staff requirements were developed after a review of the functions that must be performed during the decommissioning operations. These functions are illustrated in the decommissioning functional organization chart presented in Figure 7.7-1. The chart is applicable to all three decommissioning modes considered in this study, although the effort required in each area can vary significantly between modes. The seven general types of functions performed during decommissioning are described briefly below:

- Project Management - prepare and implement the decommissioning plan in a safe and cost-effective manner.

- Quality Assurance (QA) - develop the QA plan and monitor the safety and performance of the decommissioning operations.

- Decommissioning Operations - develop the decommissioning plan and carry out the actual decommissioning activities.

- Plant Operations and Maintenance - operate and maintain plant equipment that must be operated during the decommissioning.

- Health and Safety Protection - develop methods to assure the protection of the health and safety of the public and decommissioning workers.

- Safeguards and Security - provide protection of the site and facility from unauthorized entry and safeguard Special Nuclear Material (SNM). 
Support Services - provide accounting, procurement and stores, secretarial and clerical services in support of the decommissioning operations.

This functional organization chart was used to develop a decommissioning staff line organization to carry out these functions for each mode in an efficient manner. The line organizations developed are modeled after the organization used in the Elk River Reactor dismantlement. (11)

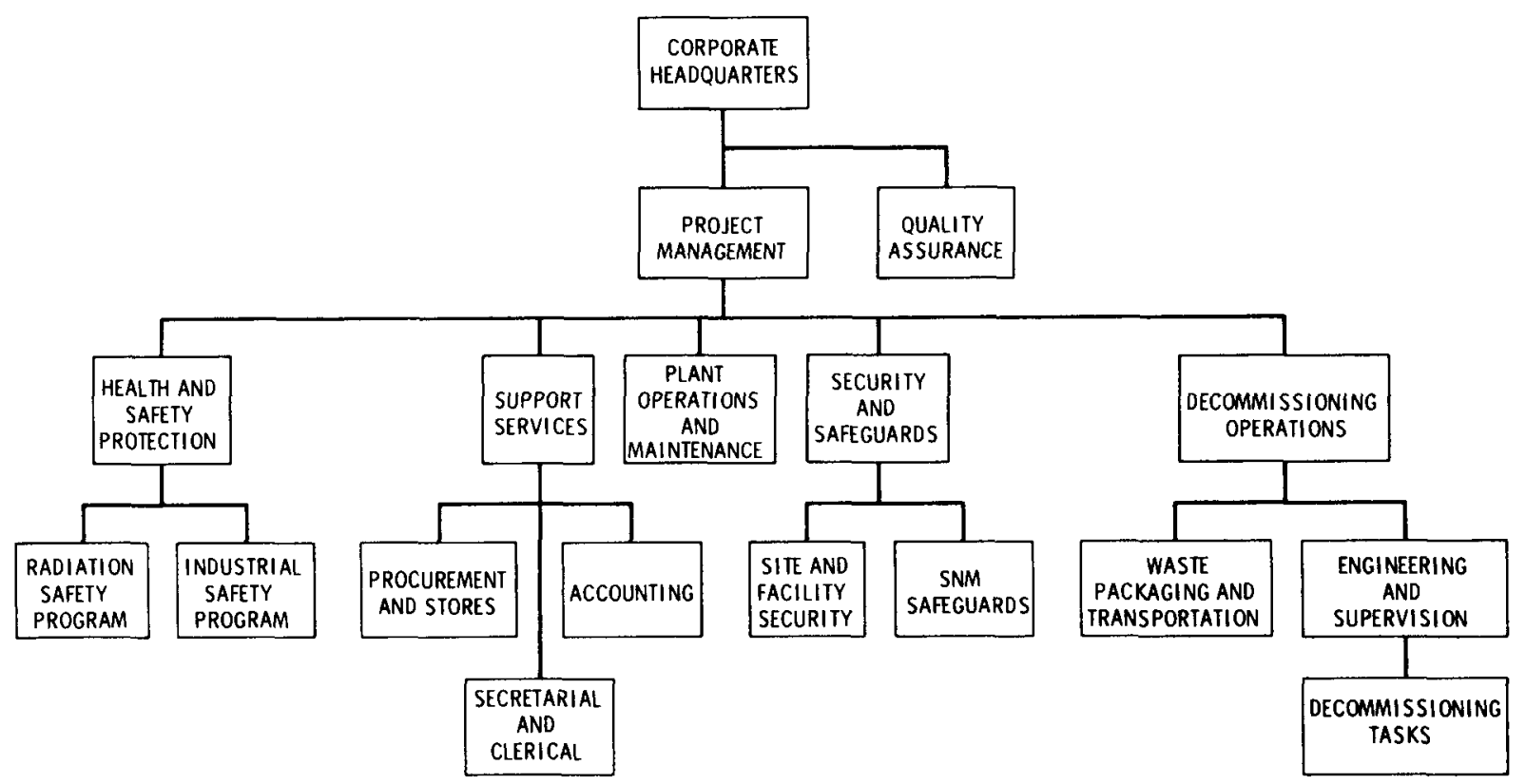

FIGURE 7.7-1. Functional Organization Chart for Decommissioning the Reference Fuel Reprocessing Plant

The staff organization developed for dismantlement of the reference fuel reprocessing plant is presented in Figure 7.7-2. The dismantlement staff organization consists of two basic parallel branches reporting to the project manager. The operational branch, under the project engineer, plans and carries out the dismantlement activities. The safety branch, directed by the health and safety supervisor, plans and conducts the radiological and industrial safety program. Safeguards and security supervisors and the project accountant also report directly to the project manager. Quality assurance personnel work with the project manager to develop and implement the quality 
assurance program, but report directly to corporate headquarters in quality assurance matters. An independent safety review committee also reports directly to corporate headquarters to recommend policy in safety-related areas.

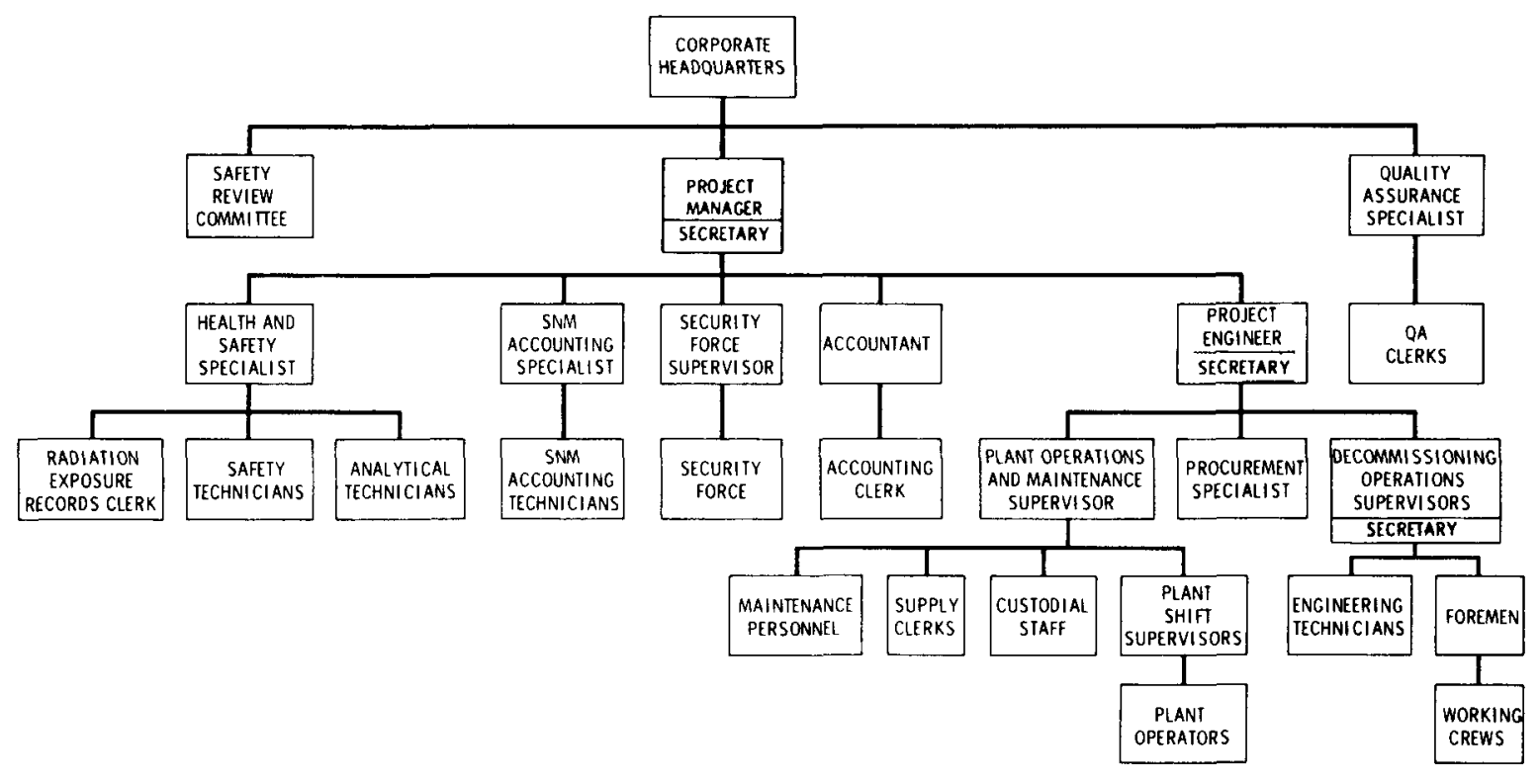

FIGURE 7.7-2. Staff Organization for Dismantlement of the Reference Fuel Reprocessing Plant

Job descriptions for key individuals in the dismantlement staff organization are presented in Volume 2, Appendix E.7, and summarized briefly below.

- Project Manager - responsible to corporate má... : for planning, coordination and supervision of the dismantlement ${ }^{\prime \prime i}$. ties. He provides liaison with regulatory agencies and is responsible for implementing regulatory and licensing requirements.

- Quality Assurance Specialist - develops and implements the QA plan to assure that decommissioning is performed in accordance with the decommissioning plan and QA requirements.

- Project Engineer - responsible for planning, coordinating and carrying out the direct dismantlement activities in a safe and cost-effect manner, including disposal of all radioactive wastes. 
Dismantlement Operations Supervisors - develop detailed dismantlement activity procedures and specifications and, through the foremen, supervise the performance of decommissioning activities.

- Plant Operations and Maintenance Supervisor - responsible for operating and maintaining plant equipment and services required during the dismantlement.

- Security Force Supervisor - responsible for site and facility security.

- SNM Accounting Specialist - responsible for carrying out the Special Nuclear Material (SNM) monitoring, accounting and protection program.

- Health and Safety Supervisor - responsible for developing and implementing the radiation and industrial safety program.

- Safety Review Committee - meets monthly to advise corporate headquarters on safety-related matters. It is composed of six voting members--two from corporate headquarters and four independent consultants. The project manager, quality assurance specialist, health and safety supervisor and project engineer are nonvoting members.

Dismantlement support staff labor requirements are shown in more detail in Table 7.7-1. The staff is grouped into the functional categories given in Figure $7.7-1$.

The dismantlement support staff is assembled during the planning phase. The initial management staff consits of the Project Manager, Project Engineer, Quality Assurance Specialist, Health and Safety Supervisor and Project Accountant. Other staff personnel are added as their services are required during the planning and operational phases. Site security is assumed by the dismantlement staff at plant shutdown. The support staff is gradually reduced toward the end of the dismantlement operations. It is anticipated that the support staff is composed primarily of plant operations opersonnel. Some key positions may be filled by outside personnel with expertise in dismantlement techniques or other skills not available from plant forces. 
TABLE 7.7-1. Summary of Estimated Support Staff Labor Requirements for Immediate Dismantlement of the Reference Fuel Reprocessing Plant

Employees (No)

Project Management Personnel

Project Manager

Quality Assurance Personnel

Quality Assurance Specialist

Assistant Quality Assurance Specialist

Quality Assurance Clerks (3)

Decommissioning Operations Personnel

Project Engineer

Decommissioning Operations Supervisor (3)

Operations and Maintenance Supervisor

Engineering Technicians (3)

Radioactive Waste Disposal Clerk

Radioactive Waste Disposal Specialist

Maintenance Technicians (4)

Shift Supervisors (2)

Operatıng Technicans (4)

Heal th and Safety Protection Personnel

Safety Review Comm ttee

Health and Safety Supervisor

Radiation Safety Specialist

Industrial Safety Specialist

Safety Technicians (b)

Laboratory Supervisor

Analytical Technicians (2)

Radiation Exposure Records Clerk

Safeguards and Security Personnel

SNM Accounting Specialist

SNM Accounting Technicians (3)

Secur1ty Force Supervisor

Security Guards (c)

Support Services Personnel

Procurement Specialist

Procurement Clerk

Supply Clerks (2)

Custodians (2)

Accountant

Accounting Clerk

Secretaries (5)

TOTALS

\section{Man-Years of Labor Planning Phase Dismantlement Phase}

\begin{tabular}{|c|c|}
\hline 20 & 51 \\
\hline 20 & 51 \\
\hline 15 & 46 \\
\hline 06 & 109 \\
\hline
\end{tabular}

\begin{tabular}{|c|c|}
\hline 20 & 51 \\
\hline 54 & 153 \\
\hline 03 & 23 \\
\hline 30 & 138 \\
\hline 05 & 46 \\
\hline 15 & 46 \\
\hline-- & 92 \\
\hline 04 & 46 \\
\hline-- & 184 \\
\hline
\end{tabular}

$\begin{array}{rr}\text { (a) } & \text { (a) } \\ 20 & 51 \\ 18 & 51 \\ 18 & 51 \\ 02 & -\cdots \\ 02 & 25 \\ -- & 50 \\ 03 & 51\end{array}$

$\begin{array}{rr}15 & 03 \\ 03 & 09 \\ 01 & 51 \\ -- & 289\end{array}$

$\begin{array}{rr}10 & 32 \\ 10 & 30 \\ -- & 92 \\ -- & 92 \\ 20 & 51 \\ 15 & 51 \\ 100 & 256 \\ 43 & 230\end{array}$

(a) Six members, meeting one day per month throughout the planning and dismantlement phases This totals 144 man-days during planning and 360 man-days during dismantlement that charged to decomissioning

(b) Man-years listed here are for radiation surveys at plant shutdown Safety technician labor during the dismantlement is included in Table 7 7-5

(c) Three guards per shift are assumed until chemical decontamination operations in the main process bullding have been completed 
The line organization chart developed for layaway and protective storage is presented in Figure 7.7-3. The same organization is used for these two modes because the types of activities required are similar. The organization is simplified from the dismantlement organization, since the complexity of the activities carried out for layaway and protective storage is significantly reduced. Job descriptions are similar to those presented previously for dismantlement. Summaries of the support staff labor requirements for protective storage and layaway are presented in Tables 7.7-2 and 7.7-3.

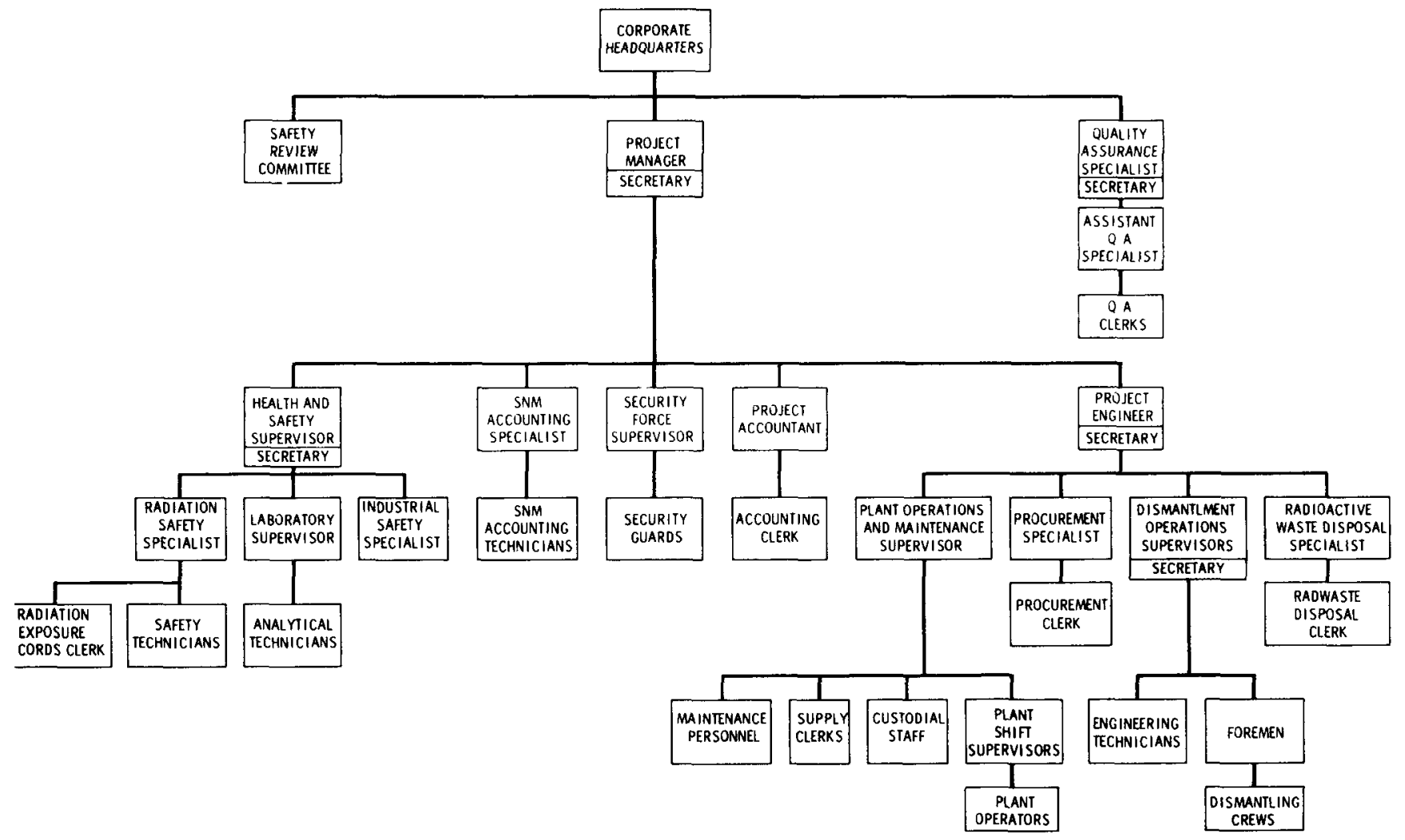

FIGURE 7.7-3. Staff Organization for Layaway and Protective Storage of the Reference Fuel Reprocessing Plant

\subsubsection{Decommissioning Worker Requirements}

Detailed estimates of the decommissioning workers and total time required to perform each of the basic decommissioning tasks discussed in Sections 7.3 through 7.5 are presented in Volume 2, Appendix E.7. The methodology used to velop those estimates and a summary of the results is presented in this section. 


\section{TABLE 7.7-2. Summary of Estimated Support Staff Labor Requirements for Protective Storage of the Reference Fuel Reprocessing Plant}

\author{
Employees (No.)
}

Project Management Personnel

Project Manager

Qual ity Assurance Personnel

Quality Assurance Specialist

Quality Assurance Clerks (2)

Decommissioning Operations Personnel

Project Engineer

Decommissioning Operations Supervisor (2)

Operations and Maintenance Supervisor

Englneering Technicians (2)

Maintenance Technicians (4)

Shift Supervisor

Operating Technicians (4)

Health and Safety Protection Personnel

Safety Review Committee

Health and Safety Specralist

Safety Technicians (b)

Analytical Technicians (2)

Radiation Exposure Records Clerk

Safeguards and Security Personnel

SNM Accounting Specialist

SNM Accounting Technicians (3)

Security Force Supervisor

Security Guards (5) (c)

Support Services Personnel

Procurement Specialist

Supply Clerk

Custodians (2)

Accountant

Accounting Clerk

Secretaries (3)

TOTALS

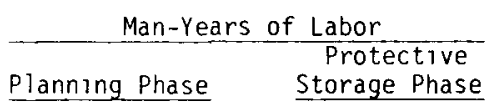

2.0

20

2.5

04

5.0

2.0

2.5

36

50

03

2.1

2.0

5.0

--

8.4

02

2.1

--

10.0

(a)

(a)

2.0

2.5

02

-

--

2.0

0.3

2.5

15

0.3

03

0.9

01

2.5

-.

15.8

\begin{tabular}{rr}
05 & 2.3 \\
-- & 25 \\
-- & 5.0 \\
2.0 & 25 \\
15 & 25 \\
6.0 & $\frac{75}{27}$ \\
\hline$\frac{94}{27}$
\end{tabular}

(a) Six members, meeting one day per month throughout the planning and protective storage phases. This totals 144 man-days for planning and 180 man-days for protective storage that is charged to decommissioning.

(b) Man-years listed here are for radiation surveys at plant shutdown Safety technician labor during protective storage is included in Table 7.7-6

(c) Three guards per shift are assumed until chemical decontamination operations in the main process building are completed. 


\section{TABLE 7.7-3. Summary of Estimated Support Staff Labor Requirements for Layaway of the Reference Fuel Reprocessing Plant}

Employees (No )

Project Manager Personnel

Project Manager

Quality Assurance Personnel

Quality Assurance Specialist

Quality Assurance Clerks (2)

Decommissioning Operations Personnel

Project Engineer

Decommissioning Operations Supervisors (2)

Operations and Maintenance Supervisor

Engineering Technicians (2)

Marntenance Technicians (4)

Shift Supervisor

Operatirig Technicians (4)

Health and Safety Protection Personnel

Safety Review Committee

Heaith and Safety Specialist

Safety Technicians (b)

Analytical Technicians

Radiation Exposure Records Clerk

Safeguards and Secur1ty Personnel

SNM Accounting Specialist

SNM Accounting Technicians (3)

Security Force Supervisor

Security Guards (c)

Support Services Personnel

Procurement Specialist

Supply Clerk

Custodians (2)

Accountant

Accounting Clerk

Secretaries (3)

TOTALS
Man-Years of Labor

Planning Phase Layaway Phase

2.0

0.4

2.3

4.6

3.6

4.6

03

2.1

20

4.6

$--$

84

02

21

$--$

9.2

(a)

(a)

20

2.3

02

$--$

$--$

1.5

03

2.3

15

03

0.3

0.9

01

23

--

14.8

05

21

--

2.3

$-$

4.6

2.0

23

15

23

$\frac{60}{27}$

$\frac{6}{90} 9$

(a) Six members, meeting one day per month, throughout the planning and layaway phases. This totais for planning and 164 man-days for layaway that are charged to decommissioning

(b) Man-years irsted here are for radiation surveys at plant shutdown Safety technician labor during layaway is included in Table 7 7-7.

(c) Three guards per shift are assumed until chemical decontamination operations in the main process building have been completed. 
Manpower for each event was estimated by starting with a basic decommissioning crew composed of the following personnel:

- foreman (1)

- safety technician (1)

- decommissioning technicians (4)

- equipment operator (1).

Activities required to perform an event were then reviewed and personnel were added to or deleted from the basic crew to provide an estimate of the total manpower required to perform that event. The time required to complete the event with the manpower alloted was then estimated. The basic events and estimated times were then fit together to produce the overall decommissioning schedules presented in Figures 7.3-1, 7.4-1 and 7.5-1 for dismantlement, protective storage and layaway, respectively.

A key assumption in estimating the manpower and time for the basic events is that the decommissioning work force is composed primarily of former plant operating and maintenance personnel. The decommissioning workers are therefore familiar with plant facilities and equipment and experienced with radiation working procedures. The duties and experience of the members of the basic decommissioning crew are outlined below.

- A Foreman supervises the performance of all decommissioning activities. He coordinates with the engineering staff through the decommissioning operations supervisors to plan and execute each day's activities. He assembles the crew and equipment required to perform these activities and instructs the crew on the procedures and safety precautions to be followed. The foreman is assumed to perform some of the actual decommissioning activities as well as supervise other members of his crew. It is anticipated that the foreman would have been employed in a position comparable to a process shift supervisor or maintenance supervisor during plant operations, so that he has detailed knowledge of plant systems and equipment.

- A Safety Technician is assigned to each crew to provide instruction in radiation and industrial safety precautions to be followed for each task and to monitor compliance with written radiation working procedures for 
the task. The safety technician performs on-the-job radiation measurements and has the authority to stop work on a job if any potentially unsafe situation arises.

- The Decommissioning Technicians perform the bulk of the actual decommissioning operations. They are assumed to possess a variety of skills either through past experience in the plant or through specialized training prior to or during the decommissioning. The technicians are assumed to have been employed in positions comparable to process operators, maintenance technicians or mechanical technicians during plant operations. It is anticipated that they would be qualified in several craft disciplines, including operation of much of the plant equipment.

- The Equipment Operator operates the plant cranes and other heavy equipment used during the decommissioning. It is assumed that he has experience comparable to the decommissioning technicians.

Personnel that could be added to the basic crew to carry out particular events include:

- Electricians

- Instrument Technicians

- Welders

- Pipefitters

- Explosive Experts

- Sheet Metal Workers

- Chemical Makeup Operators.

The explosives experts are assumed to be hired on a contract basis. Other personnel listed above are assumed to have been employed in the plant during operation as maintenance personnel.

Some decommissioning activites are identical to or very similar to some plant process or maintenance operations. These activites include:

- Chemical decontamination of process equipment and cells

- Solidifying chemical decontamination solutions in the waste solidification plant 
- Handling and loadout of canisters of solidified chemical decontamination solutions

- Operation of the waste tank equipment gallery during interim storage of the chemical decontamination solutions.

These operations are assumed to be performed by crews typical of those used during plant operations.

Some decommissioning activities are assumed to be performed by subcontractors, particularly during dismantlement. These activities typically involve the use of specialized equipment or capabilities and do not generally require work in radiation areas. Activities performed by subcontractors are indicated in the detailed manpower tables in Appendix E.7. The general types of activities include:

- Construction of special facilities or equipment such as the greenhouse building used in dismantling the waste storage tanks

- Installation of alarm systems required during interim care

- Demolition of buildings

- Excavation and backfilling

- Taking down the 100-m stack for the dismantlement mode.

The manpower furnished by the subcontractor has not been estimated since occupational radiation exposure is not involved. Costs were estimated on the basis of the services performed rather than the personnel required.

Summaries of the estimated decommissioning worker manpower required for each of the three decommissioning modes considered in this study are presented in Tables 7.7-4, 7.7-5 and 7.7-6. Details of these estimates are presented in Volume 2, Appendix E.7. Graphs of the total decommisssioning manpower versus time for each mode are presented in Figures 7.7-4, 7.7-5 and 7.7-6. The figures and tables indicate in which portion of the facility the work is being done. The figures also show the manpower engaged in operational-type activities performed as part of decommissioning such as operating the waste tank farm during interim storage of chemical decontamination solutions, solidification of these solutions in the waste solidification plant (WSP) and loadout of the canisters of waste in the fuel receiving and storage station (FR 
TABLE 7.7-4. Summary of Estimated Decommissioning Worker Manpower Requirements for Dismantlement of the Reference Fuel Reprocessing Plant

\begin{tabular}{|c|c|c|c|c|c|c|}
\hline \multirow{2}{*}{ Employee } & \multicolumn{6}{|c|}{ Man-Years of Labor } \\
\hline & $\begin{array}{l}\text { Main } \\
\text { Process } \\
\text { Bullding }\end{array}$ & $\begin{array}{l}\text { Liquid } \\
\text { Waste } \\
\text { Storage }\end{array}$ & $\begin{array}{c}\text { Waste } \\
\text { Solidification } \\
\text { Plant }\end{array}$ & FRSS & $\begin{array}{r}\text { Auxiliary } \\
\text { Facilities } \\
\end{array}$ & Total \\
\hline Shift Supervisor & 13 & 10 & 34 & -- & -- & 57 \\
\hline Foreman & 48 & 53 & 13 & 11 & 03 & 128 \\
\hline Safety Technician & 63 & 53 & 08 & 11 & 03 & 138 \\
\hline $\begin{array}{l}\text { Decommissioning } \\
\text { Technician }\end{array}$ & 158 & 239 & 106 & 30 & 11 & 544 \\
\hline Operating Technician & 26 & 56 & 67 & 22 & -- & 171 \\
\hline Mechanical Technician & 26 & 08 & -- & -- & -- & 34 \\
\hline Analytical Technician & 26 & 07 & -- & -- & -- & 27 \\
\hline Equipment Operator & 86 & 94 & 23 & 13 & 04 & 220 \\
\hline Welder & -- & 06 & 01 & - & -- & 07 \\
\hline Pipefitter & 19 & 27 & 05 & 03 & 03 & 57 \\
\hline Electrician & 16 & 05 & 03 & 01 & 01 & 26 \\
\hline Other Skilled Labor & 33 & $2 \underline{0}$ & 11 & $\underline{0} 2$ & 02 & 68 \\
\hline TOTALS & 514 & 572 & 271 & 93 & 27 & 1477 \\
\hline
\end{tabular}

TABLE 7.7-5. Summary of Estimated Decommissioning Worker Manpower Requirements for Placing the Referenced Fuel Reprocessing Plant in Protective Storage

\begin{tabular}{|c|c|c|c|c|c|c|}
\hline \multirow{2}{*}{ Employee } & \multicolumn{6}{|c|}{ Man-Years of Labor } \\
\hline & $\begin{array}{l}\text { Main } \\
\text { Process } \\
\text { Burlding } \\
\end{array}$ & $\begin{array}{l}\text { Liquid } \\
\text { Waste } \\
\text { Storage }\end{array}$ & $\begin{array}{c}\text { Waste } \\
\text { Solidification } \\
\text { Plant } \\
\end{array}$ & $\underline{\text { FRSS }}$ & $\begin{array}{r}\text { Auxiliary } \\
\text { Facilities } \\
\end{array}$ & Total \\
\hline Shift Supervisor & 13 & 10 & 30 & -- & -- & 53 \\
\hline Foreman & 13 & 07 & 03 & 11 & 04 & 38 \\
\hline Safety Technicran & 23 & 07 & 03 & 11 & 04 & 48 \\
\hline $\begin{array}{l}\text { Decommissioning } \\
\text { Technician }\end{array}$ & 36 & 20 & 68 & 24 & 08 & 156 \\
\hline Operating Technician & 34 & 58 & 60 & 23 & 01 & 176 \\
\hline Mechanical Technician & 30 & 12 & 01 & 01 & 45 & \\
\hline Analytical Technician & 26 & 01 & -- & -- & -- & 27 \\
\hline Equipment Operator & 08 & 06 & 02 & 09 & 03 & 28 \\
\hline Welder & 11 & 05 & 02 & 02 & 03 & 23 \\
\hline Electrician & 07 & 04 & 02 & 01 & 02 & 16 \\
\hline Pipefitter & 10 & 12 & 02 & 01 & 02 & 27 \\
\hline Other Skilled Labor & 13 & 30 & - & $-=$ & -- & 23 \\
\hline TOTALS & 224 & 152 & 173 & 83 & 28 & 660 \\
\hline
\end{tabular}


TABLE 7.7-6. Summary of Estimated Decommissioning Worker Manpower Requirements for Placing the Reference Fuel Reprocessing Plant in Layaway

\begin{tabular}{|c|c|c|c|c|c|c|}
\hline \multirow{2}{*}{ Employee } & \multicolumn{6}{|c|}{ Man-Years of Labor } \\
\hline & $\begin{array}{l}\text { Main } \\
\text { Process } \\
\text { Bullding }\end{array}$ & 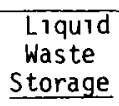 & $\begin{array}{c}\text { Waste } \\
\text { Solidification } \\
\text { Plant } \\
\end{array}$ & FRSS & $\begin{array}{r}\text { Auxiliary } \\
\text { Facilities } \\
\end{array}$ & Total \\
\hline Shift Supervisor & 13 & 10 & 30 & -- & -- & 53 \\
\hline Foreman & 07 & 02 & 02 & 10 & 02 & 23 \\
\hline Safety Technician & 18 & 02 & 02 & 11 & 02 & 35 \\
\hline $\begin{array}{l}\text { Decommissioning } \\
\text { Technician }\end{array}$ & 19 & 06 & 65 & 23 & 06 & 119 \\
\hline Operating Technician & 30 & 58 & 60 & 23 & 01 & 172 \\
\hline Mechanical Technician & 30 & 11 & 01 & 01 & -- & 43 \\
\hline Analytical Technician & 26 & 01 & -- & -- & -- & 27 \\
\hline Equipment Operator & 03 & 01 & 01 & 09 & 01 & 15 \\
\hline Welder & 02 & -- & 01 & 02 & - & 05 \\
\hline Electrician & 04 & 01 & 01 & 01 & 01 & 08 \\
\hline Pipefitter & 05 & 01 & 01 & 01 & 01 & 09 \\
\hline Other Skilled Labor & 13 & 10 & - & -- & - & 23 \\
\hline TOTALS & 170 & 103 & 164 & 81 & 14 & 532 \\
\hline
\end{tabular}

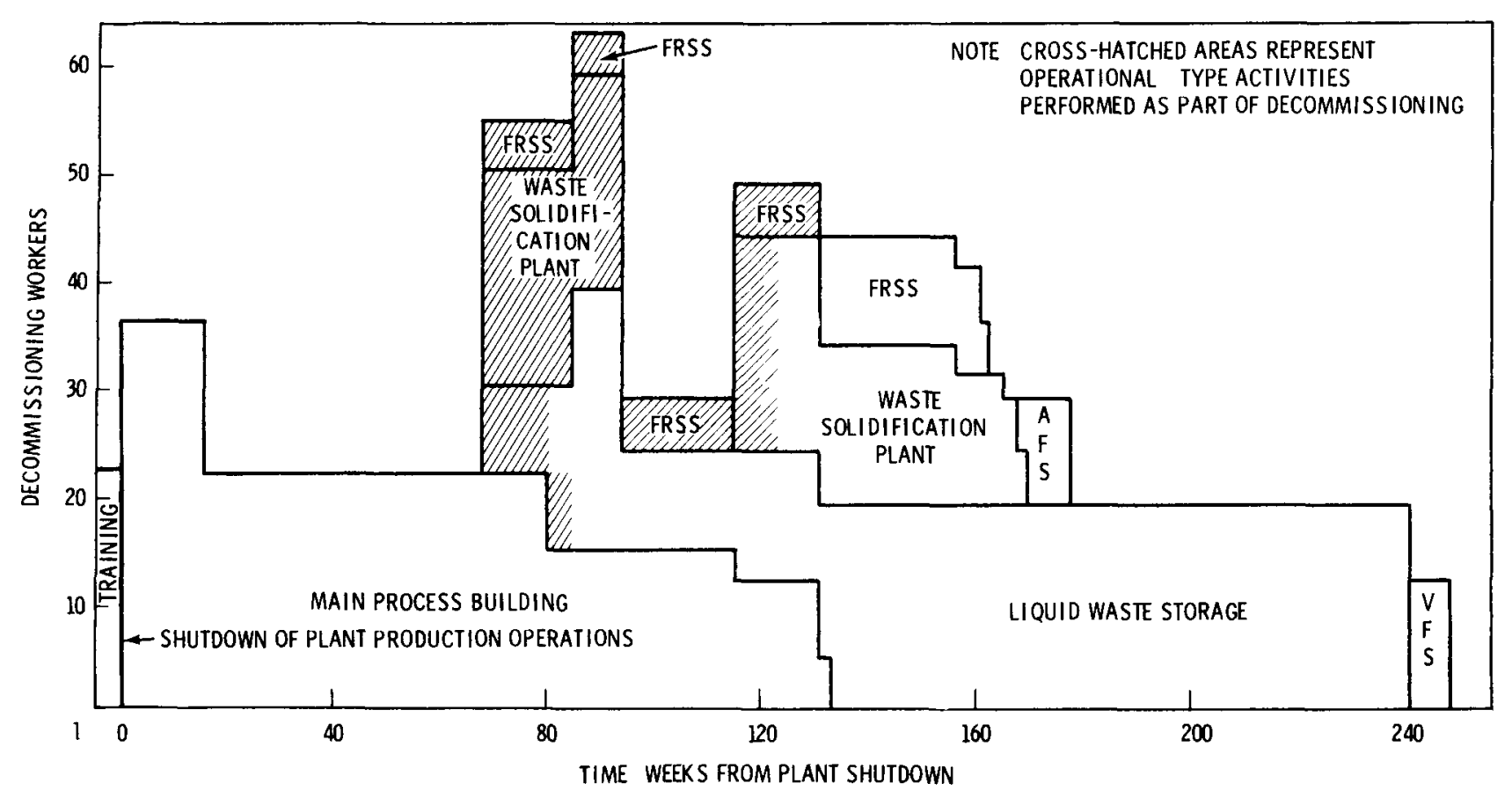

FIGURE 7.7-4. Summary of Estimated Decommissioning Worker Manpower Versus Time for Dismantlement of the Reference Fuel Reprocessing Pld 
Peaks occur in the manpower curves when solidification of residual process wastes in the WSP is completed and solidification of decommissioning chemical decontamination solutions begins. The crews performing these activities remain at their jobs, but their time is charged against decommissioning when they are processing the decontamination solutions. Similar circumstances occur in operation of the waste tank farm and the canister loadout facilities in the FRSS.

The dismantlement manpower curve (Figure 7.7-4) has two unique features. An allowance is included for specialized training of the decommissioning crews during the the final month preceding facility shutdown. This training is required because of the unique nature of many of the activities that are carried out during dismantlement and because familiarization is required with some of the specialized equipment that will be used, such as the shielded working cage. The dismantlement curve also has a valley between weeks 94 and 114. This valley occurs after most of the chemical decontamination wastes have been solidified, but before the WTEG is removed to permit the final flushes of the waste tanks to be completed. The WSP operating personnel are assumed to be employed by the facility owner in some other capacity during this period so that they are available to process the final waste tank flush solutions during months 26 through 30 .

\subsubsection{Labor Requirements During the Interim Care Period}

Activities carried out at the fuel reprocessing plant to assure the continued protection of the public health and safety during the interim care period following protective storage and layaway include:

- monitoring of operating equipment and alarm systems

- periodic radiation surveys of the facility

- periodic environmental surveys

- maintenance of operating equipment, alarm systems and protective barriers

- inspection of facility structures, protective barriers and operating equipment and alarm systems

- site and facility security

- fulfillment of regulatory requirements. 
The work force required to perform these activities during the interim care period following layaway is significantly larger than the work force for interim care following protective storage, because active environmental protection systems (e.g., the ventilation system) are operated and maintained following layaway. The organization and estimated manpower per year for the layaway interim care period are shown in Figure 7.7-7.

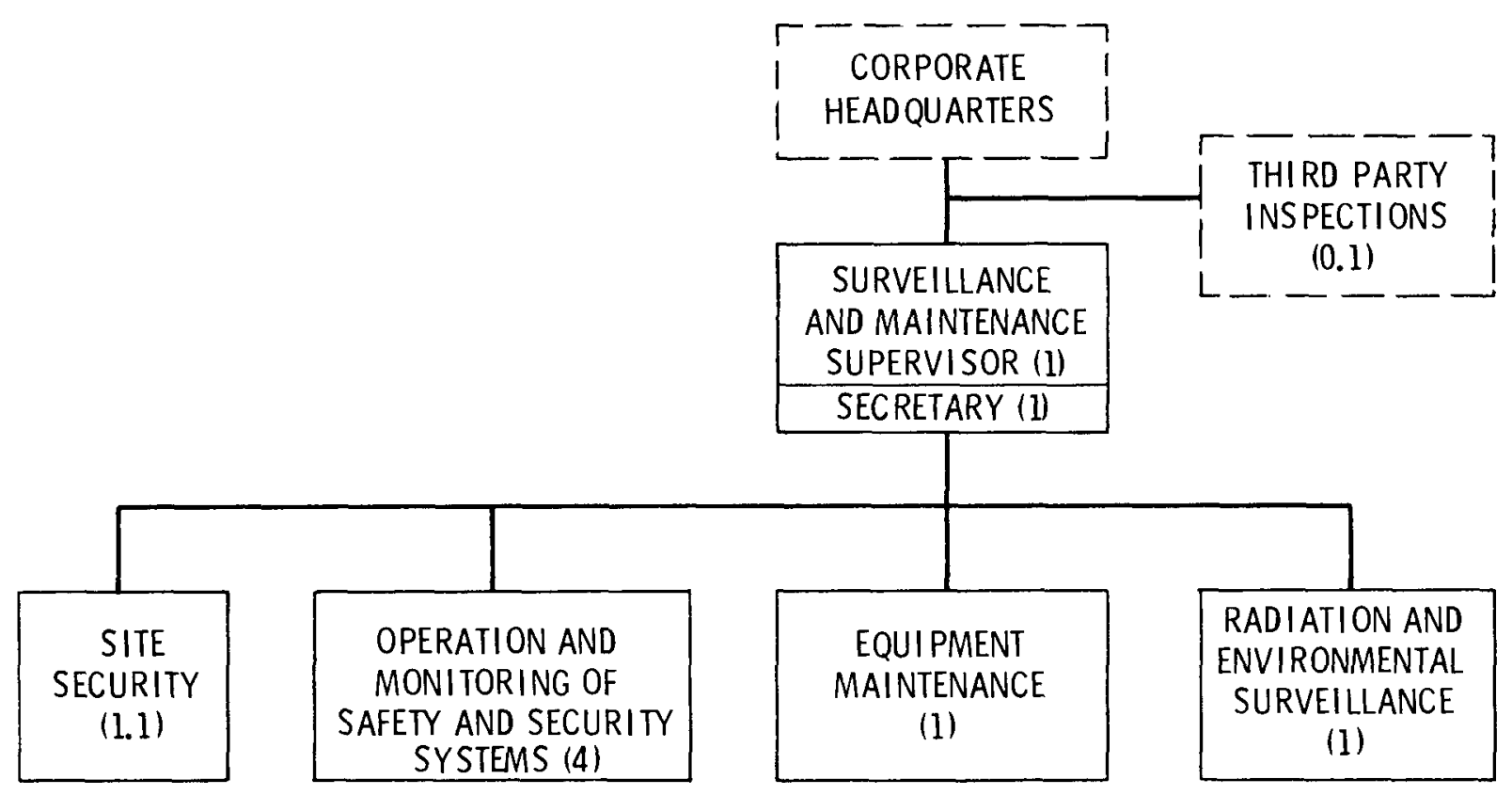

NOTE: EQUIVALENT MAN-YEARS / YR INDICATED IN PARENTHESES

FIGURE 7.7-7. Staff Organization and Estimated Manpower for Interim Care Following Layaway of the Reference Fuel Reprocessing Plant

The surveillance and maintenance activities are supervised by a full-time employee reporting directly to corporate headquarters. The surveillance and maintenance supervisor coordinates the personnel monitoring operation of the ventilation system and other operating safety systems; schedules routine and corrective maintenance and radiation and environmental surveys; performs routine physical inspections of the facility; arranges for third party inspections of facility structures and equipment; assures that all regulatory requirements are fulfilled, and makes routine reports to corporate headquarters and regulatory agencies. 
The main control room is assumed to be manned on all shifts during the interim care period to monitor the status of the ventilation system and radiation, fire and intrusion alarm systems.

The equivalent of one full-time employee is estimated to perform the radiation and environmental surveys at the facility. A security guard is assumed to be stationed at the main gate to the security protected area during the day shift. It was assumed that a contract with a local private security organization for periodic inspections of the site during the nights and weekends will cost the equivalent of 0.1 man-years of a security guard's time. Maintenance of facility equipment is estimated to require the equivalent of one full-time employee. An allowance of 0.1 man-years per year is also made for third party inspections of facility structures and equipment.

The assumed staff organization and estimated equivalent manpower requirements for the interim care period following protective storage are presented in Figure 7.7-8. The surveillance and maintenance activities are supervised by a full-time employee of the facility owner. It is estimated that these duties will require about $50 \%$ of his time. He will supervise radiation and environmental surveys; perform routine physical inspections of the facility; coordinate the personnel monitoring the fire, radiation and intruder alarms; schedule routine and preventative maintenance and third party inspections; assure that all regulatory requirements are fulfilled; and make routine reports to corporate headquarters and regulatory agencies. Maintenance, security and radiation monitoring personnel time is assumed to be purchased on a contract basis. The estimated equivalent man-years for security includes an allowance for continuous monitoring of alarm systems installed in the facility.

\subsubsection{Deferred Dismantlement Labor Requirements}

Labor requirements for deferred dismantlement following protective storage or layaway of the reference fuel reprocessing plant were estimated using the immediate dismantlement labor requirements as a basis. Adjustments were made to reflect the differences between immediate and deferred dismantlement as discussed in Sections 7.4.8 and 7.5.8. 


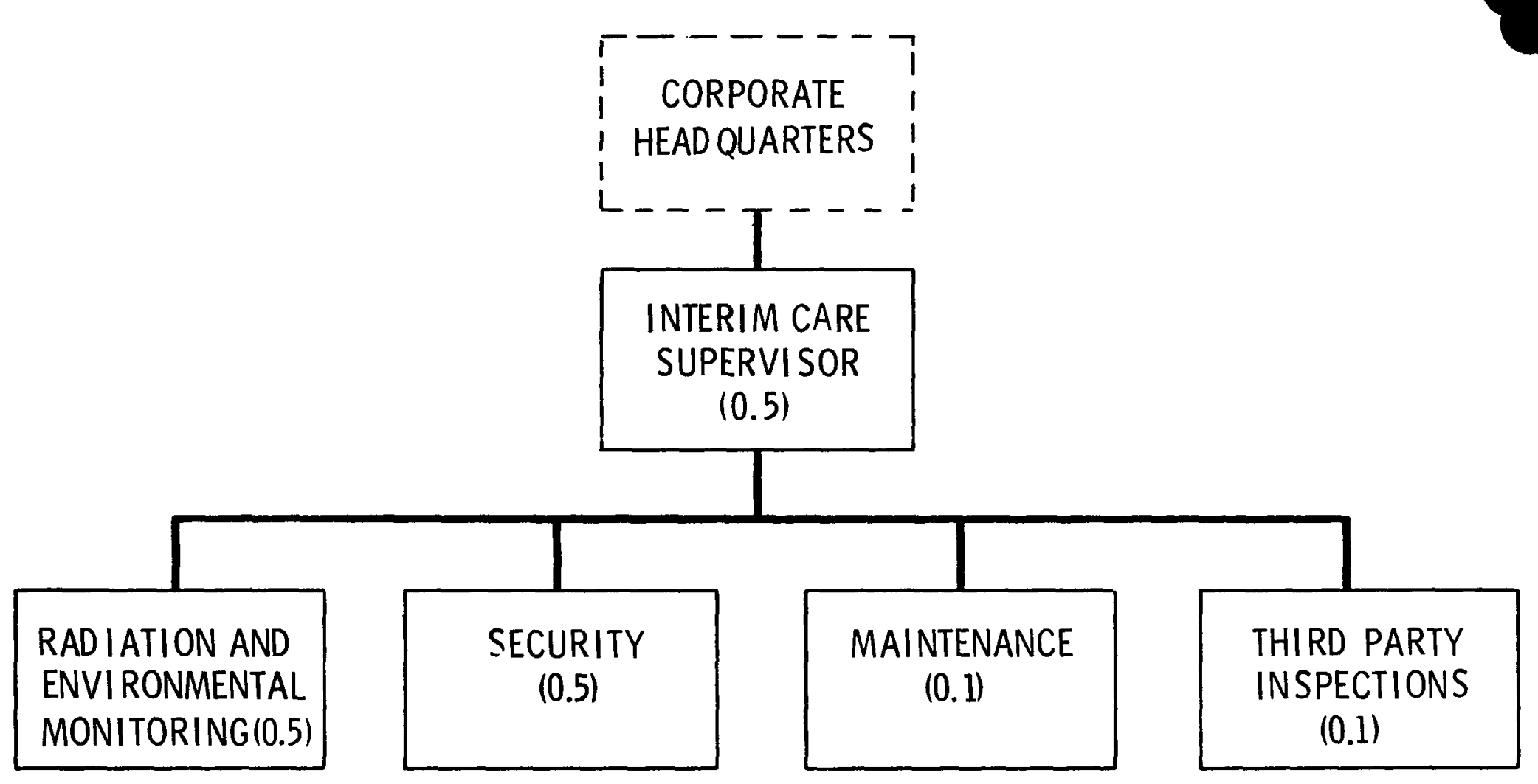

NOTE: EQUIVALENT MAN-YEARS / YR INDICATED IN PARENTHESES

FIGURE 7.7-8. Staff Organization and Estimated Manpower for Interim Care Following Protective Storage of the Reference Fuel Reprocessing Plant 
Estimated support staff labor requirements for deferred dismantlement the reference fuel reprocessing plant are presented in Table 7.7-7. It is assumed that deferred dismantlement is carried out after an extended interim care period (approximately 20 years or more) so that planning efforts for the deferred dismantlement are similar in scope to the planning efforts for immediate dismantlement. The same support staff labor requirements are used for the planning period preceding deferred dismantlement of a facility in layaway and in protective storage. The planning phase support staff labor requirements presented in the table are similar to those presented previously for immediate dismantlement. The primary differences are: 1) deletion of Special Nuclear Material accounting personnel since SNM accounting requirements are assumed to be terminated when chemical decontamination of the main process cells is completed during layaway and protective storage; 2) deletion of analytical laboratory personnel, since their functions are primarily related to chemical decontamination operations; and 3) addition of some man-years for training, since personnel familiar with the facility may not be available.

Graphs of the decommissioning worker manpower versus time for deferred dismantlement following protective storage and layaway of the reference fuel reprocessing plant are presented in Figures 7.7-9 and 7.7-10. Manpower requirements presented in the figures are based on the assumption that the decommissioning workers are experienced radiation workers, although they may not be familiar with the reference facility.

The manpower curves presented in Figures 7.7-9 and 7.7-10 are taken from the detailed immediate dismantlement manpower estimates presented in volume 2 , Appendix E.7. The primary differences reflected in the deferred dismantlement curves are: 1) deletion of chemical decontamination and associated waste solidification operations that were previously performed during layaway and protective storage; 2) addition of manpower to prepare effluent control systems, facility equipment and utilities for dismantlement; 3) changes in the dismantlement schedule permitted because liquid waste storage and solidification equipment is not required to be operated; and 4) addition of a three-month crew training period, since personnel familiar with the facility may not be available. 


\section{TABLE 7.7-7. Summary of Estimated Support Staff Labor for Deferred Dismantlement Following Protective Storage and Layaway of the Reference Reprocessing Plant}

\section{Employees (No.)}

Project Management Personnel

Project Manager

Quality Assurance Personnel

Quality Assurance Specialist

Assistant Quality Assurance Specialist

Quality Assurance Clerks (3)

Decommissioning Operations Personnel

Project Engineer

Decommissioning Operations Supervisors (3)

Operations and Maintenance Supervisor

Engineering Technicians (3)

Radroactive Waste Disposal Specialist

Marntenance Technicians (4)

Shift Supervisors (2)

Health and Safety Protection Personnel

Safety Review Committee

Health and Safety Supervisor

Radiation Safety Specialist

Industrial Safety Specialist

Safety Technicians (b)

Radiation Exposure Records Clerk

Safeguards and Security Personnel

Security Force Supervisor

Security Guards (5)

Support Services Personnel

Procurement Specialist

Procurement Clerk

Supply Clerks (2)

Custodians (2)

Accountant

Accounting Clerk

Secretaries (5)

TOTALS

\begin{tabular}{|c|c|c|}
\hline & & \\
\hline $\begin{array}{r}\mathrm{Pla} \\
\mathrm{Ph}\end{array}$ & $\begin{array}{c}\text { Deferred Dismantlement } \\
\text { Phase Follownng } \\
\text { Protective Storage }\end{array}$ & $\begin{array}{l}\text { Deferred } \\
\text { Dismantlement } \\
\text { Following Layo }\end{array}$ \\
\hline
\end{tabular}

$\begin{array}{lll}2.0 & 4.1 & 4.0\end{array}$

$\begin{array}{lll}2.0 & 4.1 & 4.0\end{array}$

$\begin{array}{lll}1.5 & 3.6 & 3.5\end{array}$

$\begin{array}{lll}0.6 & 7.9 & 7.6\end{array}$

$\begin{array}{rrr}2.0 & 4.1 & 4.0 \\ 54 & 12.3 & 12.0 \\ 0.3 & 1.7 & 1.6 \\ 3.0 & 10.8 & 10.5 \\ 15 & 3.6 & 3.5 \\ 1.2 & 6.8 & 6.4 \\ 1.2 & 6.8 & 6.4\end{array}$

(a)

(a)

(a)

2.0

4.1

4.0

2.0

4.1

4.0

2.0

4.1

4.0

0.2

$-$

$-$

0.3

4.1

4.0

0.3

4.1

40

--

20.5

20.0

1.0

3.5

34

1.0

3.2

3.1

0.4

7.2

7.0

--

7.2

7.0

2.0

4.1

4.0

15

41

4.0

100

$\underline{20 \quad 5}$

20.0

43

160

150

(a) Six members, meeting once per month throughout the planning and deferred dismantlement phases. This totals 144 man-days for planning and 288 man-days for deferred dismantlement that are charged to decommissioning.

(b)

Man-years listed here are for pre-dismantlement radiation surveys. Safety technician labor during deferred dismantlement is included in Figures 7.7-9 and 7.7-10. 


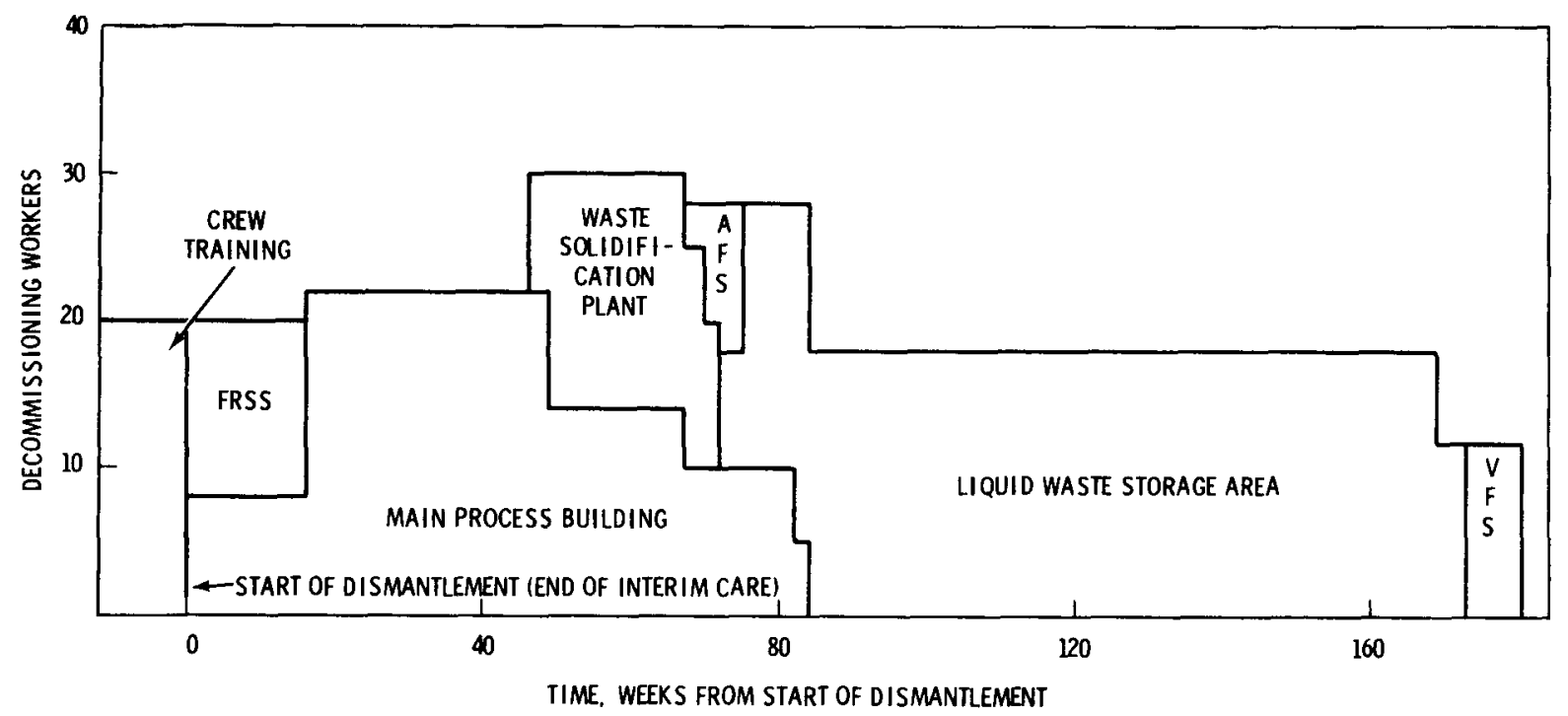

FIGURE 7.7-9. Estimated Decommissioning Worker Manpower vs. Time for Deferred Dismantlement Following Protective Storage of the Reference Fuel Reprocessing Plant

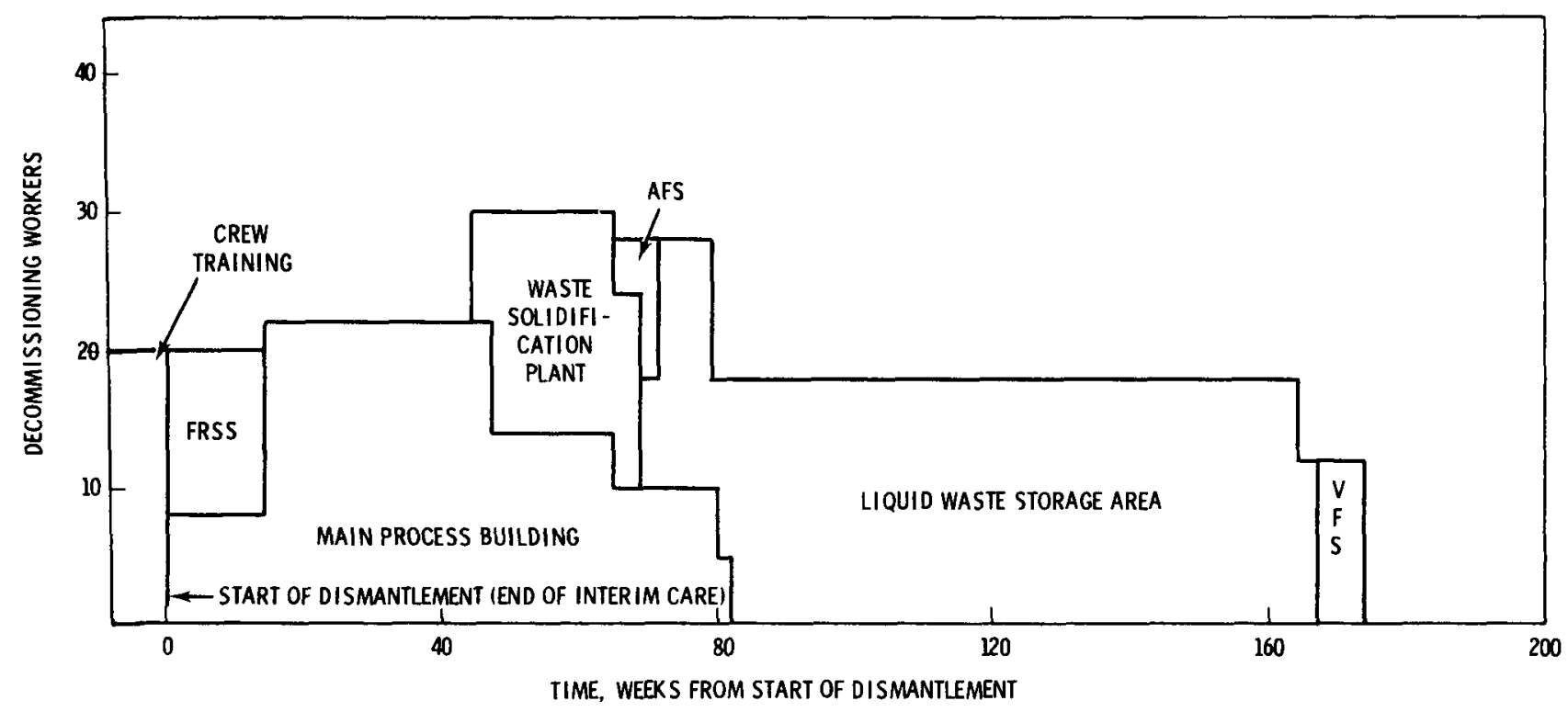

FIGURE 7.7-10. Estimated Decommissioning Worker Manpower vs. Time for Deferred Dismantlement Following Layaway of the Reference Fuel Reprocessing Plant 
Total decommissioning worker manpower for deferred dismantlement following protective storage is 4.8 man-years for crew training and 71.8 man-years for dismantlement activities. Total decommissioning worker manpower for deferred dismantlement following layaway is 4.8 man-years for crew training and 69.4 manyears for dismantlement activities. The makeup of the deferred dismantlement crews is similar to that presented previously for immediate dismantlement. 


\subsection{DECOMMISSIONING COSTS}

This section presents an estimate of the 1975 costs of decommissioning the reference fuel reprocessing plant by each of the three modes considered in this study. Costs are included for direct labor and subcontractor activities; equipment and materials; contaminated waste packaging, transportation and disposal; and utilities, services and other overheads. The costs are based on the decommissioning procedures presented in Sections 7.1 through 7.5, the waste disposal estimates presented in Section 7.6 and the manpower requirements presented in Section 7.7. Details of the bases for the cost estimates are presented in Volume 2, Appendix E.8. The cost of processing productiongenerated high level liquid wastes is not included in the decommissioning costs. These costs are considered to be an operating expense.

An allowance of $10 \%$ was added to the cost estimates to account for overhead costs of the facility owner that were not explicitly included in other cost categories. An overhead and profit rate of $25 \%$ was added to the basic costs of activities performed by subcontractors.

The basic cost estimates presented in this section assume relatively efficient performance of the decommissioning activities. A $25 \%$ contingency is added to the cost estimate totals presented in Section 7.8.7 as an allowance for unforeseen problems or scheduling delays that may arise during the decommissioning. The total costs presented are therefore believed to be representative of actual expenses that would be incurred to decommission the reference facility using the methods described in this report.

An independent review of the decommissioning costs has been performed by an architect-engineering firm (Vitro Engineering Corporation). The results of this review were used to refine the original cost estimates. These refinements are incorporated in the cost estimates presented in this section.

\subsubsection{Direct Labor and Subcontractor Costs}

Labor requirements and subcontractor activities for the three decommissioning modes were summarized in Section 7.7 and are presented in detail in Volume 2, Appendix E.7. Labor costs were calculated by estimating a pay scale for each type of employee used during the decommissioning. These pay scales. 
are presented in Table E.8-1 in Volume 2. Pay scales are based on Department of Labor statistics, (12) pay scales for similar occupations on the Hanford Atomic Reservation and labor rates for similar occupations in the construction trades. (13) Base pay rates for union (nonexempt) employees have been increased by $50 \%$ to include fringe benefits, taxes, insurance and other direct employer expenses. A 70\% increase was used for nonunion (exempt) employees. Key employees are paid a bonus of one week's pay for every three months worked as an incentive to stay until the decommissioning is completed.

\subsubsection{Support Staff Labor Costs}

The support staff consists of management, engineering, safety, maintenance, security, quality assurance and other personnel not involved directly with the decommissioning activities.

Support staff labor costs for immediate dismantlement, protective storage and layaway are presented in Tables 7.8-1,7.8-2 and 7.8-3. Support staff labor is grouped into the seven functional areas discussed in Section 7.7.1. The support staff labor costs incurred during the two year planning period preceeding decommissioning is also presented in the tables.

\section{TABLE 7.8-1. Estimated Support Staff Labor Costs for Immediate} Dismantlement of the Reference Fuel Reprocessing Plant

\begin{tabular}{|c|c|}
\hline Staff Function & $\begin{array}{l}\text { Planning } \\
\text { Phase }\end{array}$ \\
\hline Project Management & 120 \\
\hline Quality Assurance & 130 \\
\hline Decommissioning Operations & 460 \\
\hline Health and Safety Protection & 290 \\
\hline Safeguards and Security & 60 \\
\hline Support Services & 240 \\
\hline Subtota? & 1300 \\
\hline Incentive Pay & 80 \\
\hline Owner Overheads & 140 \\
\hline TOTAL & 1500 \\
\hline
\end{tabular}


TABLE 7.8-2. Estimated Support Staff Labor Costs for Placing the Reference Fuel Reprocessing Plant in Protective Storage

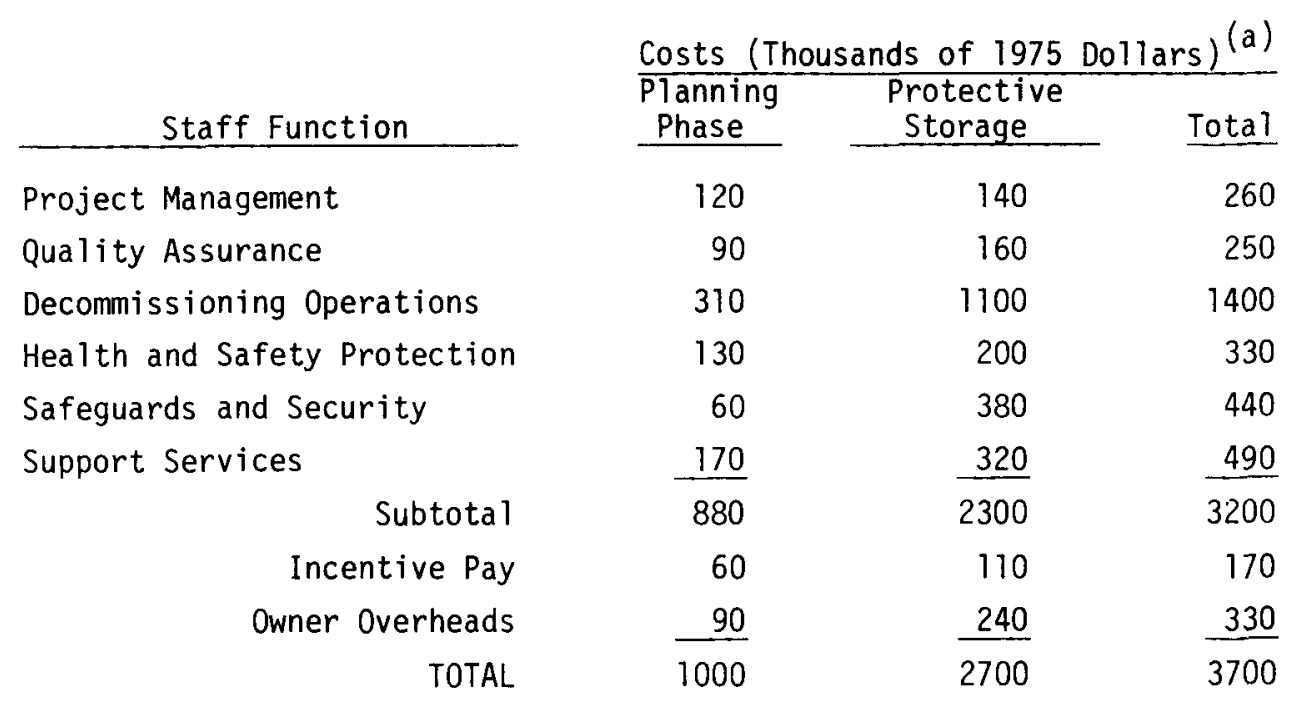

(a) All costs are rounded to two significant figures.

TABLE 7.8-3. Estimated Support Staff Labor Costs for Placing the Reference Fuel Reprocessing Plant in Layaway

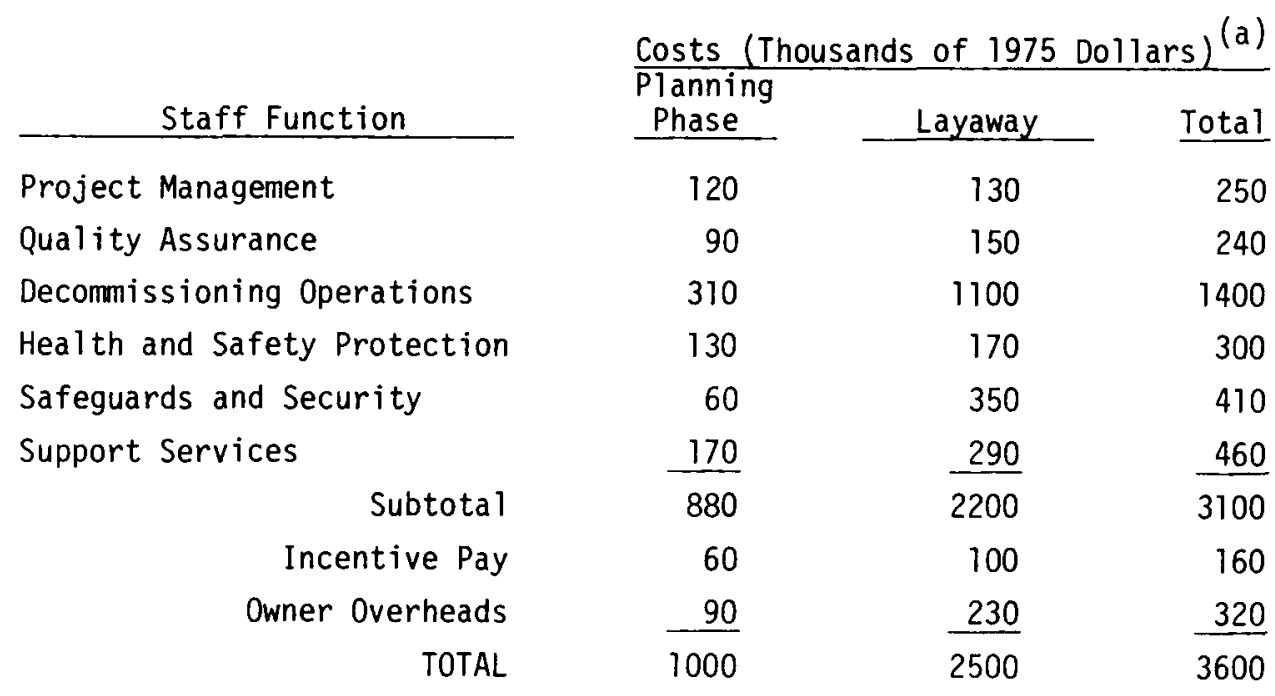

$\sqrt{(a)}$ All costs are rounded to two significant figures. 


\subsubsection{Decommissioning Worker Labor Costs}

The estimated costs of decommissioning worker labor for immediate dismantlement, protective storage and layway are presented in Tables 7.8-4 through 7.8-6. The costs are grouped by type of worker and portion of the facility in which the work takes place.

TABLE 7.8-4. Estimated Decommissioning Worker Labor Costs for Immediate Dismantlement of the Reference Fuel Reprocessing Plant

\begin{tabular}{|c|c|c|c|c|c|c|}
\hline \multirow[b]{2}{*}{ Employee } & \multicolumn{6}{|c|}{ Costs (Thousands of 1975 Dollars) $(a)$} \\
\hline & $\begin{array}{l}\text { Main } \\
\text { Process } \\
\text { Building }\end{array}$ & $\begin{array}{l}\text { Liquid } \\
\text { Waste } \\
\text { Storage }\end{array}$ & $\begin{array}{c}\text { Waste } \\
\text { Solidification } \\
\text { Plant } \\
\end{array}$ & FRSS & $\begin{array}{l}\text { Auxiliary } \\
\text { Facilities }\end{array}$ & Total \\
\hline Shift Supervisor (b) & 43 & 33 & 110 & -- & -- & 190 \\
\hline Foreman $^{(b)}$ & 160 & 180 & 43 & 36 & 10 & 420 \\
\hline Safety Technician (b) & 130 & 110 & 16 & 22 & 6 & 280 \\
\hline Decommissioning Technician(b) & 470 & 720 & 320 & 90 & 33 & 1600 \\
\hline Operating Technician (b) & 78 & 170 & 200 & 66 & -- & 510 \\
\hline Mechanical Technician & 78 & 24 & -- & -- & -- & 100 \\
\hline Analytical Technician & 52 & 2 & - & -- & -- & 50 \\
\hline Equipment Operator $(b)$ & 260 & 280 & 69 & 39 & 12 & 660 \\
\hline Pipefitter & 57 & 80 & 15 & 9 & 9 & 170 \\
\hline Welder & -- & 18 & 3 & -- & -- & 20 \\
\hline Electrician & 48 & 15 & 9 & 3 & 3 & 80 \\
\hline Other Skilled Labor & 99 & 60 & 33 & 6 & 6 & 200 \\
\hline Subtotal & 1500 & 1700 & 820 & 270 & 80 & 4400 \\
\hline Incentive Pay & 90 & 120 & 60 & 20 & 5 & 300 \\
\hline Owner Overheads & 160 & 180 & 90 & 30 & 10 & 500 \\
\hline TOTAL & 1800 & 2000 & 1000 & 300 & 100 & 5200 \\
\hline
\end{tabular}

\footnotetext{
(a) $A 11$ costs are rounded to two significant figures.

(b) Key employees receiving incentive pay.
} 
TABLE 7.8-5. Estimated Decommissioning Worker Labor Costs for Placing the Reference Fuel Reprocessing Plant in Protective Storage

\begin{tabular}{|c|c|c|c|c|c|c|}
\hline \multirow[b]{2}{*}{ Employee } & \multicolumn{6}{|c|}{ Costs (Thousands of 1975 Dollars) } \\
\hline & $\begin{array}{l}\text { Main } \\
\text { Process } \\
\text { Building }\end{array}$ & $\begin{array}{l}\text { Liquid } \\
\text { Waste } \\
\text { Storage }\end{array}$ & $\begin{array}{c}\text { Waste } \\
\text { Solidification } \\
\text { Plant } \\
\end{array}$ & FRSS & $\begin{array}{l}\text { Auxiliary } \\
\text { Facilities }\end{array}$ & Tota 1 \\
\hline Shift Supervisor (b) & 43 & 33 & 99 & -- & -- & 180 \\
\hline Foreman $(b)$ & 43 & 23 & 10 & 36 & 13 & 120 \\
\hline Safety Technician (b) & 46 & 14 & 6 & 22 & 8 & 100 \\
\hline Decommissioning Technician(b) & 110 & 60 & 200 & 72 & 24 & 470 \\
\hline Operating Technician ${ }^{(b)}$ & 100 & 170 & 180 & 69 & 3 & 530 \\
\hline Mechanical Technician & 90 & 36 & 3 & 3 & 3 & 140 \\
\hline Analytical Technician & 52 & 2 & -- & - & - & 50 \\
\hline Equipment Operator ${ }^{(b)}$ & 24 & 18 & 6 & 27 & 9 & 80 \\
\hline Welder & 33 & 15 & 6 & 6 & 9 & 70 \\
\hline Electrician & 21 & 12 & 6 & 3 & 6 & 50 \\
\hline Pipefitter & 30 & 36 & 6 & 3 & 6 & 80 \\
\hline Other Skilled Labor & 39 & 30 & - & -- & -- & 70 \\
\hline Subtotal & 630 & 450 & 530 & 240 & 80 & 1900 \\
\hline Incentive Pay & 30 & 30 & 40 & 20 & 5 & 120 \\
\hline Owner Overheads & 70 & 50 & 60 & 30 & 10 & 220 \\
\hline TOTAL & 730 & 530 & 630 & 290 & 100 & 2300 \\
\hline
\end{tabular}

\footnotetext{
(a) All costs are rounded to two significant figures.

(b) Key employees receiving incentive pay.
} 
TABLE 7.8-6. Estimated Decommissioning Worker Labor Costs for Placing the Reference Fuel Reprocessing Plant in Layaway

Employee

Shift Supervisor (b)

Foreman (b)

Safety Technician (b)

Decommissioning Technician (b)

Operatıng Technician (b)

Mechanical Technician

Analytical Technician

Equipment Operator (b)

Welder

Electrician

Pipefitter

Other Skilled Labor

$\begin{array}{rrr}\text { Labor } & \underline{39} & \underline{30} \\ \text { Subtotal } & 470 & 310 \\ \text { Incentive Pay } & 20 & 20 \\ \text { Owner Overheads } & \underline{50} & \underline{30} \\ \text { TOTAL } & 540 & 360\end{array}$

(a) A11 costs are rounded to two significant figures.

(b) Key employees receiving incentive pay.

\begin{tabular}{|c|c|c|c|c|c|}
\hline $\begin{array}{l}\text { Main } \\
\text { Process } \\
\text { Building }\end{array}$ & $\begin{array}{l}\text { Liquid } \\
\text { Waste } \\
\text { Storage }\end{array}$ & $\begin{array}{c}\text { Waste } \\
\text { Solidification } \\
\text { Plant }\end{array}$ & FRSS & $\begin{array}{l}\text { Auxiliary } \\
\text { Facilities }\end{array}$ & Total \\
\hline 43 & 33 & 99 & -- & -- & 180 \\
\hline 23 & 7 & 7 & 33 & 7 & 80 \\
\hline 36 & 4 & 4 & 22 & 4 & 70 \\
\hline 57 & 18 & 200 & 69 & 18 & 360 \\
\hline 90 & 170 & 180 & 69 & 3 & 520 \\
\hline 90 & 33 & 3 & 3 & -- & 130 \\
\hline 52 & 2 & -- & -- & -- & 50 \\
\hline 9 & 3 & 3 & 27 & 3 & 40 \\
\hline 6 & -- & 3 & 6 & -- & 20 \\
\hline 12 & 3 & 3 & 3 & 3 & 20 \\
\hline 15 & 3 & 3 & 3 & 3 & 30 \\
\hline 39 & 30 & -- & - & -- & 70 \\
\hline 470 & 310 & 500 & 240 & 40 & 1600 \\
\hline 20 & 20 & 40 & 20 & 3 & 100 \\
\hline$\underline{50}$ & 30 & 50 & 30 & 10 & 170 \\
\hline 540 & 360 & 590 & 290 & 50 & 1900 \\
\hline
\end{tabular}




\subsubsection{Costs of Subcontractor Activities}

The estimated costs of the dismantlement and protective storage activities carried out by subcontractors are summarized in Tables 7.8-7 and 7.8-8. An explanation of the bases for each of the items presented in the tables is given in Volume 2, Appendix E.8. The costs of routine construction-type activities were estimated using reference 13. Building demolition costs were estimated af.ter consultation with demolition experts. Other cost estimates were based on engineering judgment.

TABLE 7.8-7. Estimated Subcontractor costs for Immediate Dismantlement of the Reference Fuel Reprocessing Plant

Activity

Excavate to Top of 4 Waste Storage Tanks

Greenhouse Installation

Backfi11 4 Waste Tank Vaults

Lower 100 m Stack

Demolish Facility Structures

Main Process Building

Fuel Receiving and Storage Station

Waste Solidification Plant

Waste Tank Equipment Gallery

Backfill Building Cavities

Restore Site

Owner Overheads

TOTAL
Cost (Thousands of 1975 Dollars)(a)

30

62

57

25

1300

650

200

150

32

128

2600

260

2900

(a) All costs are rounded to two significant figures. 
TABLE 7.8-8. Estimated Subcontractor costs for Placing the Reference Fuel Reprocessing Plant in Protective Storage

Activities

Install Alarm Systems and Remote

Readout Capabilities

Excavate to Top of $3 \mathrm{HLLW}$ Tanks

Install Greenhouse

Inspect Welds

Change Facility Electrical Service

Subtotal

Owner Overheads

TOTAL
Cost (Thousands

of 1975 Dollars) (a)

36

8

5

25

20

94

$\underline{9}$

100

(a) A11 costs are rounded to two significant figures.

\subsubsection{Equipment and Material Costs}

Equipment and material requirements for immediate dismantlement, protective storage and layaway were determined by reviewing the decommissioning procedures presented in Sections 7.2 through 7.5. These equipment and material requirements for each mode and the estimated cost of each item are presented in Tables 7.8-9 through 7.8-11. The costs of specialized decommissioning equipment were estimated based on engineering judgment. Details of the bases for these estimates are given in Volume 2, Appendix E.8. The cost of equipment that can be purchased directly was determined from telephone quotes from suppliers. 
TABLE 7.8-9. Estimated Equipment Costs for Dismantlement of the Reference Fuel Reprocessing Plant

\section{Equipment Description}

Portable Plasma Torch and Power Supply

Track Drill

Modified Rock Splitters and Power

Supplies

Shielded Five-Ton Crane

Three-Ton Crane

Shielded Front-End Loader

Shielded Working Cage

Shielded Working Platform

Greenhouse Building

Adjustable Scaffolding

6 Jackhammers and 3 Compressors

Air Operated Rock Drill

Air Operated Hack Saw

Polyurethane Foam Generator

Mock-up and Training Facility

Radiation Detection and Analyzing

Equipment

Mist Eliminators

Flush Chemicals

Expendable Supplies

Ventilation Filter Replacement
Cost (Thousands

\begin{tabular}{ccr}
\multicolumn{4}{c}{ of 1975 Dollars)(a) } \\
\hline Quantity & Per Unit & Total \\
\cline { 2 - 3 } 5 & 50 & 250 \\
3 & 40 & 120 \\
8 & 8 & 64
\end{tabular}

(1)

100

100

1

13

13

1

1

1

(1)

(1)

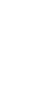

1

6

3

2

(2

(1)

1

$-$

$\begin{array}{ccr}8 & 2 & 16 \\ -- & -- & 170 \\ 50 & 15 / \text { month } & 750 \\ & & 100 \\ & \text { Subtotal } & 3500 \\ \text { Owner Overheads } & \underline{350} \\ \text { TOTAL } & 3800\end{array}$

$\overline{(a)}$ A11 costs are rounded to two significant figures. 
TABLE 7.8-10. Estimated Equipment Costs for Placing the Reference Fuel Reprocessing Plant in Protective Storage

Equipment Description

Modified Rock Splitter and Power Supply Air Operated Rock Drilis

Pneumatic Jackhammer and Compressor

Portable Plasma Torch and Power Supply Arc Welders

Paint Sprayers

Radiation Detection and Analyzing Equipment High Pressure Decontamination Sprayers Adjustable Height Mechanical Scaffold High Security Locks

Polysulfide Adhesive

3/8-in. 304L Stainless Steel Plate

Intrusion Alarm System

Ventilation Filters

Inorganic Absorbant

Temporary Greenhouse

Flush Chemicals

Mist Eliminators

Expendable Supplies
Cost (Thousands

\begin{tabular}{ccrr}
\multicolumn{2}{c}{ of 1975} & Dollars)(a) \\
\cline { 1 - 1 } \cline { 1 - 1 } Quantity & Per Unit & Total \\
\cline { 1 - 1 } 2 & 8 & 16 \\
2 & 1 & 2 \\
2 & -- & 10 \\
2 & 50 & 100 \\
2 & 1 & 2 \\
2 & 1 & 2
\end{tabular}

$\begin{array}{ccr}-- & -- & 75 \\ 4 & 2 & 8 \\ 1 & -- & 32 \\ -- & -- & 3 \\ 300 \mathrm{l} & -- & 2 \\ 65 \mathrm{~m}^{2} & -- & 8 \\ -- & -- & 100\end{array}$

20

0.1

2

4 MT

0.4

2

1

10

$\begin{array}{lll}-- & -- & 170\end{array}$

8

2

16

30 months $10 /$ month $\quad 300$

Subtotal 860

Owner Overheads $\quad$ 86

TOTAL 950

(a) All costs are rounded to two significant figures. 
TABLE 7.8-11. Estimated Equipment Costs for Placing the Reference Fuel Reprocessing Plant in Layaway

Equipment Description

Modified Rock Splitters and Power Supplies

Intrusion Alarm System

High Security Locks

Radiation Detection and Analyzing Equipment

Air Operated Rock Drills

Pneumatic Jackhammer with Compressor

Flush Chemicals

Expendable Equipment and Supplies

Mist El iminators

Ventilation Filter Replacement
Cost (Thousands

$\frac{\text { of } 1975 \text { Dollars)(a) }}{\text { Quantity Per Unit Total }}$

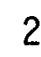

2

1

8

16

100

100

$\begin{array}{lll}-- & -- & 3\end{array}$

$-$

2

1

$--$

75

2

$-$

27 months

8

$\begin{array}{cr}2 & 16 \\ -- & 100 \\ \text { Subtotal } & 630 \\ \text { Owner Overheads } & \frac{63}{690} \\ \text { TOTAL } & 690\end{array}$

(a) $A 11$ costs are rounded to two significant figures.

7.8.3 Decommissioning Waste Packaging, Transportation and Disposal Costs

The basic data used to estimate the decommissioning waste management costs are presented in Table 7.8-12. The cost of high-level waste canisters is estimated from the materials and construction techniques that are currently expected to be used for the canisters utilized in the calciner/in-can-melter waste solidification process. The costs of other waste containers were estimated based on contacts with suppliers of similar containers that are currently available.

Freight charges for truck shipments are based on a representative rate for a 800-kilometer (500-mile) shipment of radioactive materials from Reference 14. Rail freight charges for a 2400-kilometer (1500-mile) shipment 
were extrapolated from data presented in Reference 15. Special train charges were also taken from Reference 4.

Charges for disposal of wastes in a shallow land burial ground are based on telephone quotes from operators of currently licensed burial grounds. The cost of deep geologic disposal of high-level waste is taken from Reference 16, and for low-level transuranic waste from Reference 17. The unit disposal costs for high-level wastes in Reference 16 were reduced by a factor of two for the lower heat generation rates in this study. The unit cost of disposal of intermediate-level wastes was estimated to be a factor of 10 lower than for the high-level waste disposal because the much lower heat generation from the intermediate-level wastes permits very close packing of the waste disposal containers in the repository.

For estimating waste management costs, it was assumed that four ATMX-600 railcars would be purchased to transport the wastes from dismantlement of the reference FRP. It was assumed that these cars could be resold at the end of the decommissioning. The net cost of the use of an ATMX car for the five year dismantlement period was estimated to be $\$ 100,000$. Two thousand dollars per day was been used as a representative rental charge for the cask used to ship canisters of high-level waste and one thousand dollars per day was used for the cask used to ship other decommissioning wastes that require shielding during transportation to the disposal site.

TABLE 7.8-12. Basic Decommissioning Waste Management Cost Data

\begin{tabular}{|c|c|}
\hline Expense I tem & Cost (1975 dollars) \\
\hline \multicolumn{2}{|l|}{ Container Costs } \\
\hline l $2 m \times 12 m \times 24 m$ Steel Box & 500 ed \\
\hline $12 m \times 12 m \times 12 m$ Steel $B 0 x$ & 350 ea \\
\hline Plywood Box & $40 / \mathrm{m}^{3}$ \\
\hline 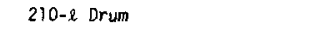 & 20 ea \\
\hline HLW Canister & $5000 \mathrm{ea}$ \\
\hline \multicolumn{2}{|l|}{ Freight Charges } \\
\hline Truck & 550 per truckload \\
\hline Rail & $11 / 100 \mathrm{~kg}$ \\
\hline Special Train Charges & $12 / \mathrm{km}$ \\
\hline \multicolumn{2}{|l|}{ Waste 0isposal costs } \\
\hline Surface Burial & $90 / \mathrm{m}^{3}$ \\
\hline \multicolumn{2}{|l|}{ Deep Geologic Disposal } \\
\hline Low-Level Waste & $2100 / \mathrm{m}^{3}$ \\
\hline Intermed late-Level waste & $7100 / \mathrm{m}^{3}$ \\
\hline High-Level Waste & $71,000 / \mathrm{m}^{3}$ \\
\hline \multicolumn{2}{|l|}{ Miscellaneous } \\
\hline ATMX Ra)lcars (Net Cost) & 100,000 ea \\
\hline \multicolumn{2}{|l|}{ Cask Rental Charges } \\
\hline High-Level Waste Cask & 2000/day \\
\hline $\begin{array}{l}\text { Intenined } 1 \text { ate-Level Waste } \\
\text { Cask }\end{array}$ & $1000 /$ day \\
\hline
\end{tabular}


The estimated costs of packaging, transporting and disposing of the was from dismantlement of the reference FRP are presented in Tables 7.8-13 and 7.8-14. Table 7.8-13 presents the costs for wastes requiring deep geologic disposal. Costs for wastes that can be disposed of in a shallow land burial ground are given in Table 7.8-14. Container costs presented in the tables include cask rental charges, where appropriate. Cask use charges are based on an estimated round trip time of 14 days for shipments to the deep geologic repository. The cost of purchasing the ATMX-600 railcars has been divided among the wastes shipped in these cars and is also included in the container cost column. Special train charges are shown for rail shipments. It was assumed that the empty cars are returned in normal train service.

TABLE 7.8-13. Estimated Packaging, Shipping and Waste Disposal Charges for Transuranic Wastes from Dismantlement of the Reference Fuel Reprocessing Plant

\begin{tabular}{|c|c|c|c|c|c|}
\hline \multirow[b]{2}{*}{ Waste Category. } & \multicolumn{5}{|c|}{ Cost (Thousands of 1975 Dollars) } \\
\hline & Container & $\begin{array}{l}\text { Freight } \\
\text { Charge }\end{array}$ & $\begin{array}{c}\text { Special } \\
\text { Train } \\
\text { Charge }\end{array}$ & Disposal & Total \\
\hline Concrete Rubble & 130 & 170 & 140 & 1,400 & 1,800 \\
\hline Stainless Steel Plate & 150 & 110 & 140 & 2,200 & 2,600 \\
\hline \multicolumn{6}{|l|}{ Equipment and Piping } \\
\hline Unshielded & 240 & 380 & 290 & 3,700 & 4,600 \\
\hline Shielded & 870 & 2,100 & 830 & 1,400 & 5,200 \\
\hline Waste Tank Sections & 70 & 53 & 64 & 1,100 & 1,300 \\
\hline \multicolumn{6}{|l|}{ HEPA and Roughing Filters } \\
\hline Unshielded & 4 & 2 & 4 & 40 & 50 \\
\hline Shielded & 30 & 72 & 28 & 36 & 120 \\
\hline Glove Boxes & 3 & 3 & 4 & 21 & 30 \\
\hline $\begin{array}{l}\text { Solidified Decontamination } \\
\text { Liquids }\end{array}$ & 980 & 1,100 & 310 & 2,500 & 4,900 \\
\hline Trash & 30 & 60 & 80 & 630 & 800 \\
\hline Subtotal & 2,500 & 4,000 & 1,900 & 13,000 & 27,000 \\
\hline Owner Overheads & 250 & 400 & 190 & 1,300 & 2,100 \\
\hline TOTAL & 2,800 & 4,400 & 2,100 & 14,000 & 23,000 \\
\hline
\end{tabular}

(a) $A 11$ costs are rounded to two significant figures. 
TABLE 7.8-14. Estimated Packaging, Shipping and Waste Disposal Costs for Low Level, Nontransuranic Wastes from Dismantlement of the Reference Fuel Reprocessing Plant

Waste Category

Concrete Rubble

Stainless Steel Plate

Equipment and Piping

Fuel Storage Racks

HEPA and Roughing Filters

Glove Boxes

Trash

$\begin{array}{rr}\text { Subtotal } & \frac{30}{400} \\ \text { Owner Overheads } & \frac{40}{440} \\ \text { TOTAL } & \end{array}$

\begin{tabular}{|c|c|c|c|}
\hline Container & Shipping & Disposal & Tota1 \\
\hline 164 & 32 & 75 & 270 \\
\hline 62 & 6 & 40 & 110 \\
\hline 110 & 24 & 70 & 210 \\
\hline 27 & 11 & 60 & 100 \\
\hline 1 & 1 & 3 & 5 \\
\hline 1 & 1 & 1 & 3 \\
\hline 30 & 12 & 27 & 70 \\
\hline 400 & 87 & 280 & 770 \\
\hline 40 & $\underline{9}$ & 28 & 77 \\
\hline 440 & 96 & 310 & 850 \\
\hline
\end{tabular}

(a) $A 11$ costs are rounded to two significant figures.

The estimated waste management costs for the layaway and protective storage modes are presented in Table 7.8-15. The majority of the costs for these modes results from packaging, transportation and disposal of the solidified liquids from chemical decontamination of the main process building and liquid waste storage tanks.

\subsubsection{Costs of Utilities, Taxes and Other Owner Expenses}

The estimated costs of utilities, taxes and other owner expenses for immediate dismantlement and layaway or protective storage are presented in Tables 7.8-16 and 7.8-17. The expenses included in the tables are:

- electricity and other utilities

- license fees paid to the Nuclear Regulatory Commission

- property taxes

- nuclear liability and conventional insurance premiums 
TABLE 7.8-15. Estimated Packaging, Shipping and Waste Disposal Costs for Low Leve1, Nontransuranic Wastes from Dismantlement of the Reference Fuel Reprocessing Plant

Waste Category

\begin{tabular}{|c|c|c|c|c|}
\hline Cost & (Thousar & $s$ of 197 & Dollars) & \\
\hline Container & $\begin{array}{l}\text { Freight } \\
\text { Charge }\end{array}$ & $\begin{array}{l}\text { Special } \\
\text { Train } \\
\text { Charge }\end{array}$ & Disposal & Total \\
\hline
\end{tabular}

TRU Wastes

HEPA and Roughing Filters

Shielded

Unshielded

Trash

Solidified Decontamination Liquids

Non-TRU Wastes

HEPA and Roughing Filters

Trash

\begin{tabular}{|c|c|c|c|c|c|}
\hline & 15 & 6 & - & 14 & 35 \\
\hline Subtotal & 1100 & 1300 & 400 & 3200 & 6000 \\
\hline Owner Overheads & 110 & 130 & 40 & 320 & 600 \\
\hline TOTAL & 1200 & 1400 & 440 & 3500 & 6600 \\
\hline
\end{tabular}

(a) All costs are rounded to two significant figures.

$\begin{array}{rrrrr}4 & 2 & 4 & 40 & 50 \\ 30 & 72 & 28 & 36 & 170 \\ 30 & 60 & 80 & 630 & 80 \\ 980 & 1100 & 310 & 2500 & 4900\end{array}$

\section{TABLE 7.8-16. Estimated Costs of Utilities,} Taxes and Other Owner Expenses During Dismantlement of the Reference Fuel Reprocessing Plant

\section{Expense Item}

License Fees

Electricity and Other Utilities

Taxes

Nuclear Liability and Other Insurance

TOTAL
Costs (Thousands of 1975 Dollars)

250

1400

150

500 
TABLE 7.8-17. Estimated Costs of Utilities, Taxes and Other Owner Expenses During Protective Storage or Layaway of the Reference Fuel Reprocessing Plant

\begin{tabular}{|c|c|}
\hline Expense Item & $\begin{array}{l}\text { Cost (Thousa } \\
\text { of } 1975 \quad \text { Doll }\end{array}$ \\
\hline License Fees & 250 \\
\hline Electricity and Other Utilities & 600 \\
\hline Taxes & 75 \\
\hline $\begin{array}{l}\text { Nuclear Liability and Other } \\
\text { Insurance }\end{array}$ & 250 \\
\hline TOTAL & 1200 \\
\hline
\end{tabular}

The primary use of electricity during decommissioning is to operate the ventilation system. The ventilation blowers consume about $850 \mathrm{~kW}$ of electricty. Using an electricity rate of $\$ 0.03 / \mathrm{kWh}$, the annual electricity cost is $\$ 225,000$. Total costs of electricity, other utilities and their maintenance are estimated to be double this amount or $\$ 450,000$ per year. For dismantlement, these costs are estimated to be reduced to $\$ 335,000$ during the third year of the dismantlement period and to $\$ 100,000$ per year during the last two years as the requirements for ventilation air and other electricity needs are reduced. For layaway and protective storage, utility costs are estimated to be reduced to $\$ 150,000$ per year after decommissioning activities in the main process building have been completed (approximately 40 weeks after plant shutdown).

The operating 1 icense fee for a reprocessing plant is currently set by the Nuclear Regulatory Commission at $\$ 250,000$ per year. (18) The amount of this fee that would have to be paid during the decommissioning period has not been determined. For estimating decommissioning costs, it has been assumed that the full fee would be paid until processing operations in the waste solidification plant are completed. The fee during the time that plant production wastes are being solidified is considered an operational expense and is not charged against decommissioning expenses. The fee for the year in which decommissioning waste liquids are processed is considered to be a decommissioning expense. The icense fee for a facility with a possession-only license is $\$ 600$ per year. 
This cost is used for the period following termination of the waste solidification operations. However, it is possible that some form of modified operating license would be required during this period, resulting in higher license fees.

Property taxes for the facility site are included as a decommissioning expense since use of the entire site is assumed to be restricted until decommissioning activities are completed. Taxes were computed based on a property value of $\$ 1000$ per hectare ( $\$ 2500$ per acre) and an assumed rate of a $10 \mathrm{mill}$ / $\$ 1000$ assessment rate. It is assumed that the radioactive portions of the facility have no property value.

The cost of nuclear liability insurance for a facility being decommissioned has also not been determined. An allowance of $\$ 100,000$ is included for the annual insurance premium for nuclear liability and conventional insurance.

\subsubsection{Interim Care Costs}

The annual costs of the activities carried out during the interim care period following protective storage and layaway of the reference FRP are presented in Tables 7.8-18 and 7.8-19. The bases for most of these costs are the same as those presented in the previous sections for similar costs. Labor costs are based on the manpower estimates presented in Section 7.7.3 and the labor cost schedules given in Volume 2, Table E.8-1. Equipment and material requirements are estimates based on engineering judgment. For protective storage taxes are computed for the exclusion area of the site only, since it is assumed for this study that the remainder of the site can be put to alternative uses by the owner. Layaway taxes are computed on the entire site. The license fee is for a possession-only license. (18) Insurance premiums are assumed to be $\$ 10,000$ per year because of the low probability of an accident with resultant low-consequence during the interim care period. Utilities for the interim care period following layaway are based on continued operation of the ventilation system at flow rates about half of those used during facility operation. A nominal utility charge to cover electricity for lighting and instrumentation is included for the interim care period following protective storage. 
TABLE 7.8-18. Estimated Annual Costs of the Interim Care Activities After Protective Storage of the Reference Fuel Reprocessing Plant

\section{Expense Item}

Annual Costs

(Thousands of

1975 Dollars)(a)

Labor

Interim Care Supervision

21

Radiation and Environmental Monitoring

Security

Maintenance

Inspections

Equipment and Materials

Utilities

Taxes

Insurance

10

License Fee

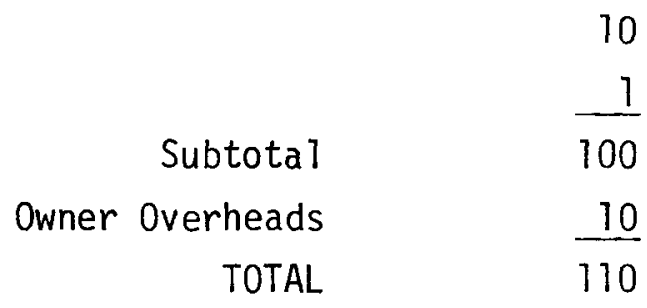

$\overline{(a)}$ A11 costs are rounded to two significant figures. 
TABLE 7.8-19. Estimated Annual costs of Interim Care Activities After Layaway of the Reference Fuel Reprocessing Plant

Expense Item

Annual cost

(Thousands of

\begin{tabular}{lr}
\multicolumn{1}{c}{ Expense Item } & \\
\cline { 1 - 2 } Labor & 42 \\
Interim Care Supervision & 12 \\
Secretarial & 20 \\
Security & 34 \\
Radiation and Environmental Monitoring & \\
Operation and Monitoring of Safety and & 120 \\
Security Systems & 30 \\
Equipment Maintenance & 10 \\
Inspections & 50 \\
Equipment and Materials & 1 \\
License Fee & 150 \\
Utilities & 15 \\
Taxes & $\frac{10}{490}$ \\
Insurance & $\frac{49}{540}$ \\
& Subtotal \\
(a) All costs are rounded to two significant figures.
\end{tabular}

\subsubsection{Deferred Dismantlement Costs}

The costs of dismantling the reference FRP at the end of the interim care periods following layaway and protective storage were estimated using the immediate dismantlement costs as a starting point. Adjustments in the costs were made to reflect the differences between the immediate dismantlement and deferred dismantlement activities as discussed in Sections 7.4.8 and 7.5.8. The bases for these adjustments are discussed in the following sections. The 
deferred dismantlement costs are believed to be relatively independent of the length of the interim care period for interim care periods ranging from 10-100 years.

\subsubsection{Deferred Dismantlement Labor and Subcontractor Cost}

Support staff labor costs for deferred dismantlement following protective storage of the reference FRP are presented in Table 7.8-20. These costs are based on the support staff manpower requirements presented in Section 7.7.4. Support staff costs for the planning period preceding deferred dismantlement for a facility in layaway are assumed to be the same as for protective storage. The support staff labor costs during the deferred dismantlement following layaway are estimated to be 4.3 million dollars (versus 4.5 million dollars for deferred dismantlement following protective storage) since these activities require about 6 weeks less time than deferred dismantlement following protective storage.

TABLE 7.8-20. Estimated Support Staff Labor Costs for Deferred Dismantlement Following Protective Storage of the Reference Fuel Reprocessing Plant

\section{Staff Function}

Project Management

Quality Assurance

Decommissioning Operations

Health and Safety Protection

Safeguards and Security

Support Services

Decommissioning Worker Training Subtotal

Owner Overheads

TOTAL

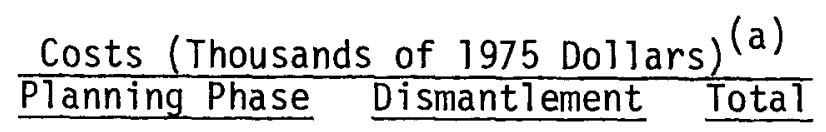

$\begin{array}{r}120 \\ 130 \\ 460 \\ 290 \\ 40 \\ 240 \\ 200 \\ \hline 1500 \\ 150 \\ \hline 1600\end{array}$
240 360 490 2700 930 520 960 720 $\frac{0}{4100} \quad \frac{200}{5600}$ $\frac{410}{4500}$ 560 6100

$\overline{(a)} \mathrm{A} 11$ costs are rounded to two significant figures. 
The costs of decommissioning worker labor is estimated from the manpower graphs presented in Section 7.7.4. Total decommissioning worker manpower for deferred dismantlement following protective storage is 77 man years and following layaway 74 man years. The average decommissioning worker labor cost for immediate dismantlement (including owner overheads) is $\$ 40,000$ per man year. Using this average decommissioning worker labor cost and the manpower totals presented above gives a decommissioning worker labor cost for deferred dismantlement of 3.1 million dollars following protective storage and 3.0 million dollars following layaway.

The estimated cost of the subcontractor activities associated with deferred dismantlement following protective storage and layaway are presented in Tables 7.8-21 and 7.8-22. Details of these estimates are presented in Volume 2, Appendix E.8.

TABLE 7.8-21. Estimated Subcontractor Costs for Deferred Dismantlement After Protective Storage of the Reference Fuel Reprocessing Plant

\section{Activity}

Dismantlement Activities from Table 7.8-7

Refurbish Ventilation and Emergency Electrical Systems

Install Larger Electrical Service to Plant

Refurbish Cranes

Install Temporary Electrical Service in Plant to Supply Dismantlement Equipment

Subtotal

Owner Overheads

TOTAL
Cost (Thousands of 1975 Dollars)
2600

150

(a) Costs are rounded to two significant figures. 


\section{TABLE 7.8-22. Estimated Subcontractor Costs for Deferred Dismantlement After Layaway of the Reference Fuel Reprocessing Plant}

Activity

Costs (Thousands

\begin{tabular}{|c|c|}
\hline Activity & of 1975 Doll \\
\hline $\begin{array}{l}\text { Dismantlement Activities from } \\
\text { Table 7.8-7 }\end{array}$ & 2600 \\
\hline Refurbish Cranes & 100 \\
\hline $\begin{array}{l}\text { Install Temporary Electrical Service } \\
\text { in Plant to Supply Dismantling } \\
\text { Equipment }\end{array}$ & 20 \\
\hline Subtotal & 2700 \\
\hline Owner Overheads & 270 \\
\hline TOTAL & 300 \\
\hline
\end{tabular}

(a) Costs are rounded to two significant figures.

\subsubsection{Deferred Dismantlement Equipment and Material Costs}

Equipment and material requirements for deferred dismantlement are very similar to the requirements for immediate dismantlement presented in Section 7.8.2. Some materials associated with chemical decontamination operations, e.g., flush chemicals, mist eliminators and radiation detection and analyzing equipment, are not required for deferred dismantlement. Subtracting these items from the cost totals presented in Table 7.8-10, gives equipment and material costs for deferred dismantlement of 3.5 million dollars.

\subsubsection{Deferred Dismantlement Waste Management Costs}

Waste disposal requirements for deferred dismantlement are essentially the same as for immediate dismantlement. Some wastes such as the solidified decontamination solutions included in Table 7.8-13 for immediate dismantlement will have been removed during protective storage or layaway operations. After adjusting for these cost differences, deferred dismantlement waste management costs are estimated to be 18 million dollars. 


\subsubsection{Deferred Dismantlement Utility Costs}

The estimated costs of utilities, taxes and other expenses for deferred dismantlement following protective storage or layaway are presented in Table 7.8-23. License fees assume a possession-only license is in effect during dismantlement. It is possible that a modified operating license would be required, resulting in higher license fees. Taxes are based on the exclusion area only for protective storage and the entire site for layaway. Insurance premiums are assumed to be twice the value used for the interim care period. The cost of electricity and other utilities are similar to those used for immediate dismantlement, adjusted for the reduced time required for deferred dismantiement.

TABLE 7.8-23. Estimated Cost of Utilities, Taxes and Other Owner Expenses During Deferred Dismantlement Following Layaway or Protective Storage of the Reference Fuel Reprocessing Plant

Expense Item

License Fees

Electricity and Other Utilities

Taxes

Insurance
Cost (Thousands of 1975 Dollars) (a)

2

1100

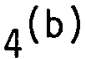

$\frac{80}{1200}$

(a) Cost totals are rounded to two significant figures.

(b) Taxes for deferred dismantlement following layaway are estimated to be $\$ 60,000$. This does not affect the cost total, to the accuracy shown.

\subsubsection{Cost Estimate Summaries}

Summaries of estimated costs for the three decommissioning modes are presented in Tables 7.8-24 through 7.8-26 from the costs developed in the preceding sections. A $25 \%$ contingency was added to the preceding costs. The cost totals are believed to be representative of the actual costs that would be incurred to decommission the reference FRP. 
TABLE 7.8-24. Summary of Cost Estimates for Immediate Dismantlement of the Reference Fuel Reprocessing Plant

Expense Item
Support Staff Labor
Decommissioning Worker Labor
Subcontractor Activities
Equipment and Materials
Shipping and Waste Disposal
Utilities, Taxes and 0ther Expenses
Cubtotal
Contingency
(a) All costs are rounded to two significant figures.
(b) Includes site restoration costs.

\begin{tabular}{|c|c|c|c|c|c|c|}
\hline Planning & $\begin{array}{c}\text { Main Process } \\
\text { Buitding } \\
\end{array}$ & $\begin{array}{c}\text { Liquid Waste } \\
\text { Storage }\end{array}$ & $\begin{array}{c}\text { Waste } \\
\text { Solidification } \\
\text { Plant }\end{array}$ & FRSS & $\begin{array}{r}\text { Auxiliary } \\
\text { Facilities } \\
\end{array}$ & Total \\
\hline \multirow[t]{6}{*}{1500} & 2300 & 2300 & 1200 & 490 & 110 & 7900 \\
\hline & 1800 & 2000 & 1000 & 300 & 100 & 5200 \\
\hline & 1400 & 350 & 220 & 730 & $140^{(b)}$ & 2900 \\
\hline & 1500 & 2000 & 140 & 100 & 50 & 3800 \\
\hline & 16000 & 6600 & 1100 & 290 & 44 & 24000 \\
\hline & 1000 & 400 & 650 & 100 & 100 & 2300 \\
\hline 1500 & 24000 & 14000 & 4300 & 2000 & 540 & 46000 \\
\hline 380 & 6000 & 3600 & 1100 & 500 & 140 & 12000 \\
\hline 1900 & 30000 & 18000 & 5400 & 2500 & 680 & 58000 \\
\hline
\end{tabular}

\section{TABLE 7.8-25. Summary of Cost Estimates for Protective Storage, Interim Care and Deferred Dismantlement of the Reference Fuel Reprocessing Plant}

\begin{tabular}{|c|c|c|c|}
\hline \multirow[b]{2}{*}{ Expense Item } & \multicolumn{3}{|c|}{ Cost (Thousands of 1975 Dollars) ${ }^{(a)}$} \\
\hline & $\begin{array}{c}\text { Protective } \\
\text { Storage } \\
\end{array}$ & $\begin{array}{l}\text { Inter im Care } \\
\text { (Per Year) }\end{array}$ & $\begin{array}{c}\text { Deferred } \\
\text { Dismantlement }\end{array}$ \\
\hline Support Staff Labor & 3700 & 44 & 6100 \\
\hline Decommissioning Worker Labor & 2300 & 22 & 3100 \\
\hline Subcontractor Activities & 100 & -- & 3200 \\
\hline Equipment and Materials & 950 & 16 & 3500 \\
\hline Shipping and Waste Disposal & 6600 & -- & 18000 \\
\hline Utilities, Taxes and Other Expenses & 1200 & 30 & 1200 \\
\hline Subtota 1 & 15000 & 110 & 35000 \\
\hline Contingency & 3700 & 28 & 8800 \\
\hline TOTAL & 19000 & 140 & 44000 \\
\hline
\end{tabular}

(a) 111 costs are rounded to two significant figures. 
Dismantlement costs for each major portion of the facility are given in Table 7.8-24. Decommissioning worker labor costs and the cost of subcontractor activities were assigned directly to a particular portion of the facility. Equipment costs were distributed according to their estimated usage in each portion of the facility. Support staff labor and utilities and other expenses were divided among the facilities according to the estimated fraction of the total dismantlement labor manpower in each facility. Shipping and waste disposal charges were taken from the waste management cost details presented in Volume 2, Appendix E.8.

Deferred dismantlement costs presented in Tables 7.8-25 and 7.8-26 are moderately lower than for immediate dismantlement. Most of the apparent cost reduction occurs because activities such as chemical decontamination and solidification of the resultant liquids are carried out during protective storage or layaway and do not have to be repeated for deferred dismantlement. Deferred dismantlement following layaway is slightly less costly than deferred dismantlement following protective storage.

TABLE 7.8-26. Summary of Cost Estimates for Layaway, Interim Care and Deferred Dismantlement of the Reference Fuel Reprocessing Plant

\begin{tabular}{|c|c|c|c|}
\hline \multirow[b]{2}{*}{ Expense Item } & \multicolumn{3}{|c|}{ Cost (Thousands of 1975 Dollars) (a) } \\
\hline & Layaway & $\begin{array}{l}\text { Interim Care } \\
\text { (Per Year) }\end{array}$ & $\begin{array}{c}\text { Deferred } \\
\text { Dismantlement }\end{array}$ \\
\hline Support Staff Labor & 3500 & 92 & 5900 \\
\hline Decommissioning Worker Labor & 1900 & 200 & 3000 \\
\hline Subcontractor Activities & & & 3000 \\
\hline Equipment and Materials & 690 & 55 & 3500 \\
\hline Shipping and Waste Disposal & 6600 & & 18000 \\
\hline Utilities, Taxes and Other Expenses & 1200 & 190 & 1200 \\
\hline Subtotal & 14,000 & 540 & 34,600 \\
\hline Contingency & 3,500 & 140 & 8,600 \\
\hline TOTAL & 18,000 & 680 & 43,000 \\
\hline
\end{tabular}

$($ a) $A 11$ cost totals are rounded to two significant figures. 
difference is primarily because the ventilation system must be reactiated for dismantlement following protective storage. Deferred dismantlement costs are apportioned among the various facilities in the plant in about the same way as for immediate dismantlement.

Waste management costs represent about $50 \%$ of the total costs for dismantlement of the reference FRP. Waste disposal costs for transuranic wastes, in turn, represent about $60 \%$ of the waste management costs. Since waste disposal costs are based on the volume of material placed in the deep geologic repository, reducing waste management costs has a significant effect in reducing decommissioning costs. For example, reduction of the volume of transuranic-contaminated equipment and piping by a factor of two would reduce waste disposal csots (including overheads and contingency) by $5.4 \mathrm{million}$ dollars. Significant economic incentives exist to develop volume reduction techniques for decommissioning wastes and to further investigate improved decommissioning techniques. For example, extensive use of electropolishing, which has the potential to decontaminate metallic wastes to releasable radioactive contamination levels or to levels that permit their disposal in shallow land burial grounds, may offer cost reductions.

Decommissioning support staff labor represents a significant percentage of the costs for all three decommissioning modes. These costs are approximately proportional to the total time required to complete the decommissioning activities. One method of reducing total decommissioning times would be to reduce inventories in the 1 iquid waste storage tanks to zero at plant shutdown. (a) This could be accomplished by judicious management of the waste solidification plant during the final years of facility operation. This activity has the potential to reduce support staff labor costs during immediate dismantlement by an estimated 2.4 million dollars; for layaway and protective storage, costs would be reduced by an estimated 1.5 million dollars. The total time for deferred dismantlement could be reduced by employing a larger crew of decommissioning workers and carrying on more dismantlement activities concurrently. Reducing the total deferrred dismantlement time by one year could reduce support staff labors costs by about 1.5 million dollars. Dismantlement costs were developed

Note that processing of production wastes after plant shutdown is not part of decommissioning. 
assuming that most work is done on day shift only. Multi-shift operations could also reduce total dismantlement time and reduce support staff costs.

The 1 iquid waste storage system represents about one-third of the total dismantlement costs. Alternative reprocessing plant designs might not employ large liquid waste storage systems. These designs would have a significant decommissioning cost advantage over the design of the reference plant.

It was assumed (see Section 7.3.7) that radioactive contamination levels on the site from routine releases during facility operation do not require extensive site cleanup operations during the dismantlement to meet the 1 imits for unrestricted use presented in Section 6. A preliminary estimate of the costs to perform these activities, should they be required, is $\$ 50,000$. This would not appreciable change the dismantlement cost totals presented in Tables 7.8-24 through 7.8-26. 


\section{REFERENCES}

1. W. E. Sande, et a1., Decontamination and Decommissioning of Nuclear Facilities - A Literature Search, BNWL-1917, Battelle, Pacific Northwest Laboratories, Richland, WA, May 1975.

2. Title 10, U.S. Code of Federal Regulations, Part 20.106 (Revised January 1, 1977).

3. J. F. Nemec and K. G. Anderson, Demolition of Radioactive and Contaminated Concrete and Structures by Use of Explosives, Presented at 1974 Annual Meeting of the American Nuclear Society, Philadelphia, PA, June 1974.

4. W. J. Bair, Pacific Northwest Laboratory Annual Report for 1976 to the ERDA Assistant Administrator for Environment and Safety, BNWL-2100 PT5, BattelTe, Pacific Northwest Laboratories, Richland, WA, June 1977, p. 26.

5. Proposed Rulemaking on Transuranic Waste Disposal. Published in Federal Register, Volume 39, No. 32922.

6. F. E. Adcock, ATMX-600 Railcar - A New Concept in Radioactive Waste Shipments, RFP-1590, The Dow Chemical Company, Rocky Flats Division, Golden, CO, April 1971.

7. F. E. Adcock, ATMX-600 Railcars for Radioactive Waste Shipments, RFP-1141, The Dow Chemical Company, Rocky Flats Division, Golden, CO, January 1970.

8. R. S. Merlini et al., "Radioactive Waste Package Development at the Rocky Flats Plant", IAEA-SR-10/26, presented at the International Seminar on the Design, Construction and Testing of Packaging for the Safe Transport of Radioactive Material, Vienna, Austria, August 1976.

9. P. L. Peterson and R. E. Rhoads, Conceptual Design of a Shipping Cask for Transporting High Level Waste by Railroad, BNWL-2244, Draft, Battelle, Pacific Northwest Laboratories, Richland, WA, September 1977.

10. Title 10, U.S. Code of Federal Regulations, Part 7.1.4 (a), Revised January 1, 1977.

11. AEC-Elk River Reactor Dismantling Plan, SS-836, Rural Cooperative Power Association, Elk River, MN, Revised, October 18, 1971, pp. 39-44.

12. Bureau of Labor Statistics Bulletin, March 1975, U.S. Department of Labor, Washington, DC.

13. R. S. Godfrey, ed., Building Construction Cost Data 1975, R. S. Means Co., Duxbury, MA, 1974. 
14. Local Commodity Tariff No. 1045-C, Docket MC-109397, Supplement 10, Tri-State Motor Transit Co., Joplin, M0, June 13, 1975.

15. W. V. Loscutoff, et al., A Safety and Economic Study of Special Trains for Shipment of Spent Fuel, BNWL-2263, Battelle, Pacific Northwest Laboratories, Richland WA, September 1977, pg A.1.

16. K. J. Schneider and A. M. Platt, Editors, High Level Radioactive Waste Management Alternatives, Report BNWL-1900, Battelle, Pacific Northwest Laboratories, Richland, WA, May 1974. p 3.73.

17. Final Generic Environmental Statement on the Use of Recycle Plutonium in Mixed Oxide Fuel in Light Water Reactors, NUREG-0002, U.S. NucTear Regulatory Commission, Washington, DC, August 1976. pg. XI-28.

18. Title 10, U.S. Code of Federal Regulations, Part 170.21, Revised January 1977 


\subsection{SAFETY OF DECOMMISSIONING A REFERENCE FUEL REPROCESSING PLANT}

A safety evaluation has been made of decommissioning a reference fuel reprocessing plant (FRP). Radiological and nonradiological safety impacts from normal operations and potential accidents were identified and evaluated for the dismantlement, protective storage, and layaway decommissioning modes. The safety areas examined include the radiation dose to the public from normal operations and potential accidents, occupational radiation exposure, industrial type accidents, and potential chemical pollutants. The approach used to assess the safety implications of a particular activity was generally conservative. The safety evaluation utilized current data and methodology, along with engineering judgment where necessary, to estimate the required input information and the resulting safety impacts.

\subsection{SCOPE OF THE SAFETY ANALYSIS}

The evaluation of each of the three decommissioning modes considered in this study (dismantlement, protective storage, and layaway) is reported separately. For this safety analysis, each decommissioning mode is divided into three sections: (1) decommissioning operations at the reference FRP; (2) transportation operations, and (3) interim care (if required).

Each decommissioning mode is examined to evaluate the safety impacts from both normal and potential accident conditions. The safety considerations are primarily those having potential for loss of radioactive material confinement and/or having the capability of exposing either the public or operating personnel to abnormally high radiation doses. Other safety factors investigated include the effect of chemical pollutants and construction/industrial-related lost-time injuries and fatalities. Radiationand nonradiation-related safety areas are discussed separately for each decommissioning mode. 
Releases of radionuclides from normal operations and potential accidents are postulated for the decommissioning methods summarized in Section 7 and detailed in Appendix E.

The consequences of radionuclide releases from normal decommissioning operations are calculated in terms of radiation dose to the maximum exposed member of the public and to the surrounding population. The consequences of radionuclide releases from potential accidents are calculated in terms of a radiation dose to a maximum exposed individual. An estimate of the frequency of occurrence is given for accidents as high ( $>10^{-2}$ per year), medium $\left(10^{-2}\right.$ to $10^{-5}$ per year), or 10 w $\left(<10^{-5}\right.$ per year) based on published values or engineering judgment and experience. A rigorous probabilistic risk assessment was beyond the scope of the study.

For radionuclide releases from normal decommissioning operations and potential accidents, the airborne release of radionuclides is assumed to be the dominant pathway to man. There are no planned liquid releases during the decommissioning operations. Inhalation of airborne radionuclides is assumed to be the dominant radiation exposure pathway to members of the public for accidental releases. Remedial action can be taken to mitigate important long term terrestrial and aquatic pathway consequences.

Direct worker radiation doses are estimated from the radiation levels in the FRP and the man-hour estimates for performing the decommissioning operations.

The nonradiation-related safety areas considered include potential chemical pollutants and construction/industrial accidents. The effects of chemical residues from plant operations, chemicals employed during decontamination, and nonradioactive fission products resulting from decay of residual isotopes are qualitatively examined. Occupational lost-time injuries and fatalities are estimated based on available statistics for construction/ operational activities and the man-hour estimates for each of these activities during decommissioning operations.

The transportation operations for each of the decommissioning modes are examined to evaluate the safety considerations for both normal operations 
and potential accidents. Potential radiation- and nonradiation-related transportation safety impacts are evaluated for the public and the worker.

\subsection{KEY ASSUMPTIONS/BASES USED IN THE SAFETY ANALYSIS}

Section 3.31 ists key study bases for the overall decommissioning study. In addition, the following list of assumptions and bases are essential to the safety analysis. The results of the safety evaluation are specific to these key assumptions/bases.

1. The storage and solidification of the inventory of stored liquid waste at plant shutdown are considered part of normal plant operations and are not considered in the decommissioning safety analysis. Decommissioning activities in various parts of the FRP main process building are assumed to result in no safety-related problems in waste storage and solidification operations.

2. The maximum potential radiological consequences of a decommissioning operation are assumed to be associated with performing the operation in the area of the FRP with the highest radionuclide inventory.

3. The maximum release for a specific type of decommissioning operation is conservatively assumed to apply to that operation whenever it is used in the facility. In performing the dose calculations for releases of radionuclides from normal operations, the estimated releases for the entire decommissioning period are summed and assumed to be released during a one-year period. Estimating the releases and their consequences in such a manner is conservative but a conservative estimate compensates for uncertainties in the analysis.

4. Inhalation of airborne radionuclides is assumed to be the dominant pathway to members of the public for radionuclide releases from potential accidents.

5. The dominant radiation exposure pathway to the decommissioning worker is assumed to be the external radiation exposure received during normal decommissioning operations. 
6. The radionuclide releases from normal operations and potential accidents for the case of dismantiement after an interim care period are assumed to be identical to those during immediate dismantlement but adjusted for radioactive decay during the interim care period.

7. The site information, facility description, initial inventory of radionuclides, decommissioning methods, and final contamination levels are all as described in the other respective sections and appendices of this report.

\subsection{DISMANTLEMENT MODE SAFETY ASSESSMENT}

The dismantlement operations for decommissioning the FRP are divided into five major stages:

- planning and preparation

- chemicar decontamination

- removal of contaminated equipment

- mechanical decontamination of structures

- structure demolition and site restoration

The procedures used in the above operations are presented in Section 7.3. Associated with the above dismantlement operations are the decommissioning waste handling and transportation activities. The contaminated waste materials from the dismantlement operations are treated where necessary and packaged for transport to the disposal site. Decommissioning wastes and waste disposal are discussed in Section 7.6.

In this safety analysis, the dismantlement mode was divided into two major portions: (1) dismantlement operations and (2) transportation.

\subsubsection{Dismantlement Operations Safety Assessment}

The dismantlement operations for the reference FRP were examined to evaluate the safety impacts of both normal decommissioning operations and potential accidents. Radiological and nonradiological safety impacts of dismantlement operations are described in this section. 


\subsubsection{Radiological Safety Impacts of Dismantlement Operations}

As is true for an operating fuel reprocessing plant, the primary safety considerations for decommissioning the reference FRP are those having the potential for loss of radioactive material confinement and/or having the capability of exposing either the general public or operating personnel to abnormally high radiation doses. Table 5.4-1 lists the anticipated radioactivity inventories in the major areas of the FRP at time of shutdown and after chemical decontamination. The estimated radioactivity levels are much lower than those of an operating fuel reprocessing plant. However, many operations performed in the dismantlement of an FRP offer a potential for release of radionuclides that is quite different than that of an operating FRP. The radiological effects from normal operations and potential accidents are estimated for the dismantlement of the reference FRP.

- Radiological Effects of Normal Dismantlement Operations

The radiological effects of normal operations in the dismantlement of the reference FRP include the radiation dose to the public from radioactive effluents and the occupational radiation exposure.

The primary sources of radioactive effluents from normal dismantlement operations are the release of contaminated liquid aerosols and chemical vapors during chemical decontamination operations, the release of condensed metal (and its associated radionuclide contamination) from equipment removal operations, and the release of contaminated concrete dust during the decontamination of concrete structures.

The consequences of radionuclide releases from normal decommissioning operations are calculated in terms of radiation dose to a maximum exposed individual and to the surrounding population. The maximum release for a specific type of decommissioning operation is conservatively assumed to apply to that operation whenever it is used in the facility.

Table 8.3-1 lists estimates of the release of radioactive effluents and the resulting radiation doses from normal dismantlement decommissioning operations. The development of the release terms is shown in detail in Appendix F.2.1. The bases for these radiation dose calculations are given in Appendix F.4. 


\section{TABLE 8.3-1. Estimated Radiation Dose to the Public From Release of Radionuclides}

During Normal Dismantlement Decommissioning Operations $(a)$

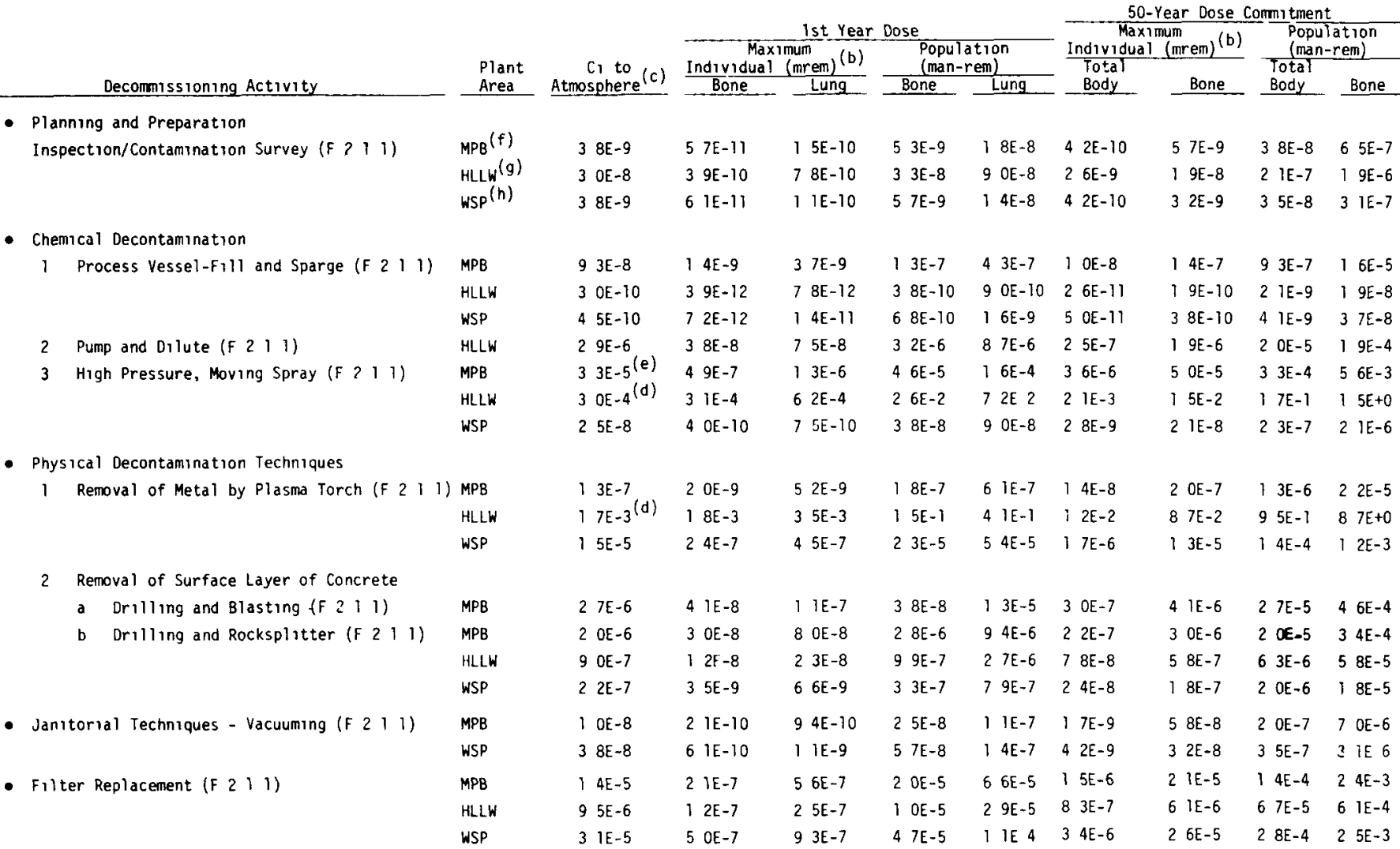

(a) Two significant figures shown for computational accuracy

(b) Maximum exposed individual is iccated one kilometer from the facility

(c) Release from 100 meter stack

(d) Release at ground level

(e) The release from chemical decontamination of the filter niche is included

(f) FRP Main Process Building

$(g)_{\text {High Level Waste Storage Areas }}$

(h) Waste Solidification Plant 
As seen from Table 8.3-1, the estimated releases are very sma 11 compared to those of an operating fuel reprocessing plant. Table C.9-1 gives the estimated radioactive effluents of an operating FRP.

The dismantlement operations with the highest release of radionuclides to the atmosphere occur in the high-level liquid waste storage area. This release is primarily from aerosol generation during spray decontamination of the high-level liquid waste tank internals and from the condensed metal vapors formed during plasma torch cutting operations on the waste tank internals.

The radiation doses given in Table 8.3-1 are all very small compared to the background radiation exposure received by members of the public. The radionuclide releases and radiation doses are low, largely because of care in designing and implementing dismantlement procedures, the greatly reduced inventory of radionuclides, and the utilization of efficient process and ventilation filtration systems.

The occupational radiation exposure is the other primary radiological impact from normal dismantlement operations. Direct worker radiation doses are estimated from the radiation levels in the various areas of the FRP and the man-hour estimates for performing the dismantlement operations in these areas. Table 8.3-2 gives the estimated occupational external radiation exposure by facility area for the total FRP decommissioning staff and for the decommissioning technicians only. The information presented in this table is derived from Table F.2-3 in Appendix F.2.2, which provides a detailed breakdown of estimated occupational dose for each dismantlement operation by facility area and type of decommissioning worker.

The total estimated occupational radiation dose for dismantlement is 512 man-rem. The dismantlement activities in the FRP main process building and the liquid waste storage area are the main contributors to this total. The specific dismantlement activities that result in the highest worker radiation doses are: (1) cut up and package operations for the liquid waste storage area, (2) cut up and package operations for the main process building, and (3) equipment removal in the High Leve1 Cell. 
TABLE 8.3-2. Estimated 0ccupational Radiation Doses From Dismantlement ${ }^{(a)}$

\begin{tabular}{|c|c|c|c|c|c|c|}
\hline \multirow[b]{2}{*}{ Facility Area } & \multicolumn{3}{|c|}{ Decommissioning Technicians (b) } & \multicolumn{3}{|c|}{$\begin{array}{l}\text { Total for All FRP } \\
\text { Decommissioning Staff }(b)\end{array}$} \\
\hline & $\begin{array}{l}\text { Man } \\
\text { Years }\end{array}$ & $\begin{array}{c}\text { Dose } \\
\text { Man-Rem } \\
\end{array}$ & $\begin{array}{l}\text { Average Worker Dose } \\
\text { Man-Rem/Quarter }\end{array}$ & $\begin{array}{l}\text { Man } \\
\text { Years }\end{array}$ & $\begin{array}{l}\text { Dose } \\
\text { Man-Rem }\end{array}$ & $\begin{array}{l}\text { Average Worker Dose } \\
\text { Man-Rem/Quarter }\end{array}$ \\
\hline Main Process Building & 45.1 & 219 & 1.21 & 51.4 & 241 & 1.17 \\
\hline Liquid Waste Storage & 45.5 & 183 & 1.00 & 51.8 & 197 & 0.95 \\
\hline Waste Solidification Plant & 22.4 & 46.8 & 0.52 & 27.1 & 51.2 & 0.47 \\
\hline Fuel Receiving and Storage & 8.2 & 18.6 & 0.57 & 9.3 & 19.8 & 0.53 \\
\hline Auxiliaries & $\underline{2.4}$ & $\underline{3.14}$ & $\underline{0.33}$ & $\underline{2.1}$ & $\underline{3.25}$ & $\underline{0.30}$ \\
\hline TOTALS (rounded) & 124 & 471 & $0.95^{(c)}$ & 142.3 & 512 & $0.90^{(d)}$ \\
\hline
\end{tabular}

(a) Major assumptions for the calculations:

- All personnel are experienced radiation zone workers

- Technicians available for work in zones for six hours/shift

- Technicians only spend $50 \%$ available time in high radiation fields

- Foreman and safety technicians spend $20 \%$ of their time in high radiation fields

- Cutup and packaging crews work at an average integrated exposure rate of $8 \mathrm{mR} /$ hour, using shielding (portable and fixed) to reduce the dose rate when handling high exposure materials

(b) Three significant figures shown for computational accuracy

(c) Average for all decommissioning technicians

(d) Average for all decommissioning staff 
The average worker quarterly radiation dose estimates given in Table 8.3-2 are for the same work crew performing the dismantlement operations in the given area. Operations in the main process building result in the highest average worker quarterly radiation dose. The average worker radiation dose is below 1.25 man-rem per quarter.

Since the average worker's dose for the dismantlement operations in the different areas of the FRP is typically below $1.25 \mathrm{rem} /$ quarter, no potential problems are expected in keeping below $1.25 \mathrm{rem} /$ quarter for the actual case of a worker performing dismantlement operations in several areas of the facility. Administrative controls are assumed to be in place that keep radiation records for each individual and assure that no one individual is assigned dismantlement tasks that result in exceeding 1.25 man-rem per quarter.

The estimates of the occupational radiation exposure are sensitive to management philosophy and to the decommissioning methods utilized. The above estimates are based on dismantlement methods that utilize specialized shielding devices and highly trained technicians. Different basic assumptions or dismantlement procedures may change the worker radiation dose estimates significantly.

- Radiological Effects of Potential Dismantlement Accidents

The primary radiological effect of dismantlement accidents is the potential release of radioactive material and the resulting radiation dose to the public. The dominant radiation pathway to the decommissioning worker is assumed to be the external radiation exposure obtained during normal dismantlement operations. Carefully designed dismantlement radiation working procedures including the use of respiratory protection (e.g., masks, fresh air suits) in contaminated areas minimize the potential for inhalation of radioactivity by the decommissioning worker.

The dismantlement procedures were examined and potential accidents were postulated that could lead to the release of radioactive materials. The consequences of radionuclide releases from potential accidents are calculated in terms of radiation dose to a maximum exposed individual. 
The wide spectrum of postulated accidents for decommissioning the refer FRP is given in Appendix F.2.1.2 along with the detailed calculations and assumptions for developing the estimates of the release terms. Table 8.3-3 lists the higher consequence accidents postulated for dismantlement and the resulting radiation doses. The bases for the radiation dose calculations are given in Appendix F.4.

The dominant accident identified for dismantlement operations is a severe earthquake occuring during the equipment decontamination phase of the high-level waste tanks. The tank containment integrity is diminished by a large penetration as part of the decommissioning activity. At this stage of the dismantlement operations, the radionuclide inventory is orders of magnitude less than immediately after the HLLW tanks are emptied and flushed. The radioactivity is firmly attached to the metal surfaces. The earthquake is postulated to destroy the greenhouse surrounding the tank penetration and result in a release of approximately 3 curies of radioactivity directly to the atmosphere. The probability of this accident is estimated to be in the low range.

The largest radiation dose to the maximum exposed individual from a postulated operations related accident is the failure of the ventilation system HEPA filter during the high-level waste tank chemical decontamination operations. Approximately $60 \mathrm{mCi}$ of radioactivity are assumed to be released directly to the atmosphere. This release results in a first-year dose of 14 mrem to the lung and a fifty-year dose commitment of $160 \mathrm{mrem}$ to the bone of the maximum exposed individual.

Population dose calculations were not performed for the postulated dismantlement accidents. A conservative upper limit can be placed on the expecte population dose by comparing Table 8.3-1 and Table 8.3-3. For a release of the same type and quantity of radionuclides, the ratio of the dose to the maxi exposed individual for an accidental release and a release from normal operations can be obtained. An upper limit for an accidental release population dose is this ratio times the population dose for the release from normal operations. The actual population dose for an accidental release is expected to be considerably below this upper limit. 
TABLE 8.3-3. Estimated Radiation Dose to the Public from Accidental Release of Radionuclides during Dismantlement Decommissioning Operations(a)

\begin{tabular}{|c|c|c|c|}
\hline & & 1st Year Dose & 50-Year Dose Commitment \\
\hline & $\mathrm{Ci}$ to & $\begin{array}{c}\text { Maximum } \\
\text { Individual }(\mathrm{b}) \text { (mrem) }\end{array}$ & Maxjpum \\
\hline Accident & Atmosphere & Bone Lung & Bone \\
\hline
\end{tabular}

- Main Process Building

Segmentation by Plasma Torch of Equipment not Chemically Decontaminated

$\begin{array}{llllll}1.7 \mathrm{E}-6^{(\mathrm{C})} & 7.5 \mathrm{E}-6 & 2.4 \mathrm{E}-5 & 5.1 \mathrm{E}-4 & 3.2 \mathrm{E}-5 & \text { Medium } \\ 4.0 \mathrm{E}-4^{(\mathrm{C})} & 1.8 \mathrm{E}-3 & 5.6 \mathrm{E}-3 & 1.2 \mathrm{E}-1 & 7.6 \mathrm{E}-3 & \text { Medium }\end{array}$

Filter Failure During Chemical Decontamination

(2)

$\begin{array}{llllll}1.9 E-3^{(d)} & 1.3 E-1 & 4.4 E-1 & 5.1 E+0, & 5.1 E-1 & \text { High } \\ 1.9 E-2^{(d)} & 1.3 E+0 & 4.4 E+0 & 5.1 E+1 & 5.1 E+0 & \text { Medium } \\ 2.8 E-2^{(d)} & 1.9 E+0 & 6.5 E+0 & 7.5 E+1 & 7.5 E+0 & \text { Low } \\ 6.0 E-2^{(d)} & 4.1 E+0 & 1.4 E+1 & 1.6 E+2 & 1.6 E+1 & \text { Medium } \\ 3.3 E+0^{(d)} & 2.3 E+2 & 7.7 E+2 & 8.8 E+3 & 8.8 E+2 & \text { Low }\end{array}$

- Liquid Waste Storage Area

Loss of Contamination Control System-Plasma Torch

Segmentation by Plasma Torch of Equipment not Chemically Decontaminated

Tornado

Filter Fallure During Chemical Decontamination Severe Earthquake

- Waste Solidification Plant (WSP)

Filter Failure During Chemical Decontamination

\begin{tabular}{|c|c|c|c|c|c|}
\hline $5.0 \mathrm{E}-6^{(c)}$ & $1.5 E-5$ & $4.8 E-5$ & $6.0 E-4$ & $5.5 E-5$ & Mediun \\
\hline $1.3 E-5^{(c)}$ & $3.9 E-5$ & 1. $2 E-4$ & $1.6 \mathrm{E}-3$ & $1.4 E-4$ & High \\
\hline $7.5 E-5^{(c)}$ & 2. $3 E-4$ & 7. $2 E-4$ & $9.0 \mathrm{E}-3$ & $8.3 E-4$ & Medium \\
\hline
\end{tabular}

Loss of Filtration During Vacuuming

$$
7.5 E-5^{(c)}
$$

2. $3 E-4$

$1.2 E-4$

(9. -3

(a) Two significant figures shown for computational accuracy.

(b) Maximum exposed individual is located one kilometer from the facility.

(c) Release from $100 \mathrm{~m}$ stack.

(d) Release at ground level.

(e) High greater than IE-2 per year; medium $1 E-2$ to $1 E-5$ per year; low less than $1 E-5$ per year. 
As seen in Table 8.3-3 and Appendix F.2.1.2, the radiation dose to the maximum exposed individual for the accidents postulated for dismantlement operations is typically smaller than that received from natural background radiation exposure. The potential accidental radionuclide releases and radiation doses are low largely because of the relatively low residual radionuclide inventories after chemical decontamination, the efficiency of the facility ventilation treatment systems, and the dilution of the airborne releases in the atmosphere.

\subsubsection{Nonradiological Safety Impacts of Dismantlement}

The primary nonradiation related safety impacts from dismantlement operations include the effect of chemical pollutants and construction/ industrial-related lost-time injuries and fatalities.

- Potential Chemical Pollutants

Potential chemical pollutants that could be released during dismantlement operations were examined and found to be insignificant. Appendix F.2.3 presents a discussion of potentially hazardous chemicals from three sources: (1) residua from FRP production operations, (2) chemicals employed during chemical decontamination operations, and (3) nonradioactive fission products resulting from decay of residual radionuclides. The small quantities of hazardous chemicals and the low likelihood of their dispersal into the environs indicate that potential chemical pollutants from dismantlement operations do not pose a significant public hazard.

\section{- Construction/Industrial Accidents}

As is the case for any industrial operation, the potential exists for worker injuries and fatalities as a result of dismantlement operations. Proper management attention and industrial safety procedures in the dismantlement operations will minimize the potential for worker injuries and fatalities. Table F.2-5 in Appendix F.2.4 provides a summary of accident experience for the United States Atomic Energy Commission in the period 1943-1970. Estimates 
are given for worker injury and fatality frequencies for heavy construction, light construction, and operations activities. Using these accident rates estimates were made of potential worker injuries and fatalities from dismantlement operations. These are summarized in Table 8.3-4. As seen from the Table, a potential of 1.7 lost-time injuries and 0.009 fatalities would be expected to occur during the 5 years of dismantlement operations.

TABLE 8.3-4. Estimated Worker Lost-Time Injuries and Fatalities from Dismantlement Operations(a)

\begin{tabular}{|c|c|c|c|c|c|}
\hline \multirow[b]{2}{*}{ Activity } & \multirow[b]{2}{*}{ Man-Hr. } & \multicolumn{2}{|c|}{$\begin{array}{c}\text { Frequency }(b) \\
\text { Accidents } / 10^{6} \text { Man-Hr. }\end{array}$} & \multicolumn{2}{|c|}{$\begin{array}{c}\text { Occupational Safety } \\
\text { Accidents/Dismantlement }\end{array}$} \\
\hline & & $\begin{array}{l}\text { Lost-Time } \\
\text { Injuries }(c) \\
\end{array}$ & Fatalities & $\begin{array}{l}\text { Lost-Time } \\
\text { Injuries }\end{array}$ & Fatalities \\
\hline Heavy Construction & 100,000 & 10 & $4.2 E-2$ & 1.0 & $4.2 E-3$ \\
\hline Light Construction & 93,000 & 5.4 & $3.0 E-2$ & .50 & $2.8 E-3$ \\
\hline Operations & 91,000 & 2.1 & $2.3 E-2$ & .19 & $2.1 E-3$ \\
\hline TOTAL & 284,000 & & & 1.7 & $9.1 E-3$ \\
\hline
\end{tabular}

(a) Two significant figures shown for computational accuracy

(b) Accident frequency data from Table F.2-5

(c) Lost-time injuries are as defined in American National Standards Institute Method of Recording and Measuring Work Injury Experience - ANSI Z16.1-1967 (Revision of Z16.1-1964)

\subsubsection{Dismantlement Transportation Safety}

Radioactive wastes generated during the dismantlement of a FRP must be packaged and shipped offsite for disposal. These wastes include transuranic contaminated (TRU) wastes that are shipped by rail to a Federal repository and non-TRU wastes that are shipped by truck to a commercial burial ground.

The procedures and standards for the packaging and transport of radioactive wastes are discussed in Appendix F.3.1. Federal regulations prescribe shipping container requirements, limitations on package contents, and packaging and handling procedures. Their purpose is to ensure that radioactive material shipments pose minimum risks to the public and to transportation workers. 


\subsubsection{Radiological Transportation Safety Impacts}

The radiological effects of dismantlement transportation operations include the external radiation exposure to the transportation worker and the public from normal transportation operations and the radiation exposures to the public from the potential release of radioactive material from transportation accidents.

- Radiological Effects of Normal Transportation Operations

Estimated routine radiation doses from rail and truck transport of radioactive wastes from dismantlement of a FRP are shown in Tables 8.3-5 and 8.3-6. Dose calculations are based on maximum allowable dose rates for shipment in exclusive-use vehicles and are therefore conservative. Information on the number of rail and truck shipments and on shipping distances is taken from Section 7.6.

TABLE 8.3-5. Estimated Routine Radiation Dose from Rail Transport of Radioactive Wastes from Dismantlement

\begin{tabular}{|c|c|c|}
\hline Group & $\begin{array}{c}\text { Dose per Rail Shipment } \\
\text { (man-rem) }\end{array}$ & $\begin{array}{c}\text { Total Radiation Dose } \\
\text { for Ail Shipments } \\
\text { (man-rem) }\end{array}$ \\
\hline Brakeman & 0.1 & 5 \\
\hline Onlookers & 0.01 & 0.5 \\
\hline $\begin{array}{l}\text { Other General } \\
\text { Public }\end{array}$ & 0.1 & 5 \\
\hline
\end{tabular}

TABLE 8.3-6. Estimated Routine Radiation Dose from Truck Transport of Radioactive Wastes from Dismantlement

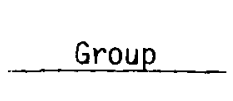

Truck Drivers Garagemen Onlookers Other General Public

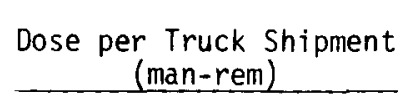

0.1

0.001

0.01

0.01

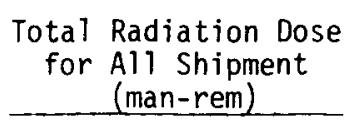

15

0.15

1.5

1.5 
The method and assumptions used in estimating the radiation dose from normal transportation operations is given in Appendix F.3.2. As seen from Tables 8.3-5 and 8.3-6 the estimated routine radiation dose is 20 man-rem to the transportation workers and 9 man-rem to the general public for the dismantlement transportation operations.

- Radiological Effects of Potential Accidents

The primary radiological effect of dismantlement transportation accidents is the potential release of radioactive material and the resulting radiation dose to the public. Estimated frequencies, release quantities, and maximum individual radiation doses for selected accidents involving rail and truck transport of radioactive wastes from FRP dismantlement are shown in Table 8.3-7. Accident severities are based on vehicle speed and fire duration as defined in Appendix F.3.2. Frequency calculations are based on probability data from Appendix F.3.2 combined with shipment data from Section 7.6. ATMX rail cars are assumed to transport an average radioactive inventory of 200 curies per car. The average radioactive inventory per truck shipment is assumed to be 100 curies per car. Rail casks are assumed to transport an average inventory of $10^{6}$ curies in the form of vitrified decontamination liquids sealed inside stainless steel canisters.

The radiation dose calculations are based on the same assumptions used for dismantlement operations accidents given in Appendix F.4. A maximum individual is assumed to be located at $100 \mathrm{~m}$ from the point of release. The radionuclide distribution is assumed to be the same as that of the remote process cell given in Appendix F.4.

As seen from Table 8.3-7 the more probable transportation accidents result in no release or a very small release. For a severe truck accident a hypothetical maximum individual located at 100 meters could receive a 50 year dose commitment to the bone of $11 \mathrm{rem}$. 
TABLE 8.3-7. Estimated Frequencies and Radioactivity Releases for Selected Accidents Involving Rail and Truck Transport of Radioactive Wastes from Dismantlement

Accident Description.

\section{Rail Transport}

Moderate severity accident with ATMX rail car

Severe accident with ATMX rail car

$\frac{\infty}{\sigma}$
Moderate severity accident with cask

Severe accident with cask

Truck Transport

Minor accident with closed van

Moderate accident with closed van

Severe accident with closed van

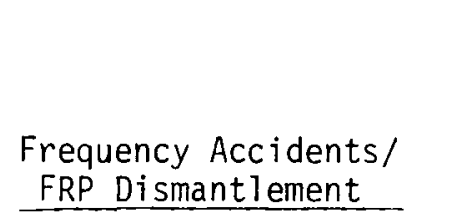

$1 E-2$

$2 E-4$

$1 E-2$

$2 E-4$

$1 E-1$

$2 E-2$

$6 E-4$

$E-2$

$$
2 E-4
$$

$1 E-4$

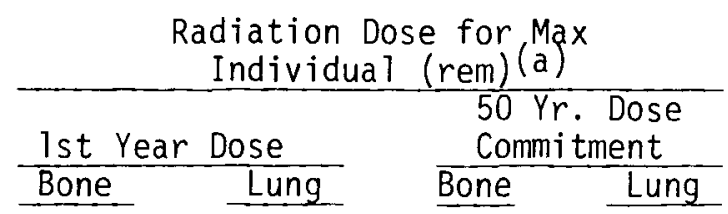

No Release

3. $3 E-3$

0.01

0.22

0.014

No Release

No Release

No Release

$1.6 \mathrm{E}-3$

$5.2 E-3$

0.11

7. $1 E-3$

0.16

0.52

11.2

0.71

\footnotetext{
(a) Maximum exposed individual is assumed at 100 meters
} 


\subsubsection{Nonradiological Transportation Safety Impacts}

The primary nonradiation-related safety impacts for dismantlement operations include the potential effect of chemical pollutants and nonradiation transportation accident injuries and fatalities.

- Potential Chemical Pollutants

The typical chemical effluents for rail and truck transportation include sulfur oxides, nitrogen oxides, hydrocarbons, and particulates. The number of train and truck shipments for transporting wastes generated from the dismantlement of a FRP is a miniscule portion of the total U.S. train and truck shipments. Negligible safety impacts are expected.

- Nonradiation Transportation Accident Injuries and Fatalities

As is the case for typical transportation activities, the potential exists for injury or death from dismantlement transportation operations. Table 8.3-8 provides estimates for potential injuries and fatalities for dismantlement transportation operations.

As shown in Table 8.3-8, potentially 0.2 injuries and 0.01 fatalities could be expected to occur as a result of dismantlement transportation operations.

TABLE 8.3-8. Estimated Injuries and Fatalities from Dismantlement Transportation Accidents

\begin{tabular}{|c|c|c|c|c|c|}
\hline \multirow[b]{2}{*}{ Mode } & \multirow[b]{2}{*}{ Kilometers } & \multicolumn{2}{|c|}{$\begin{array}{c}\text { Frequency }(\mathrm{a}) \\
\text { Accidents/106 kilometers }\end{array}$} & \multicolumn{2}{|c|}{$\begin{array}{l}\text { Transportation } \\
\text { Nonradiation Accident } \\
\text { Impact for Dismantlement }(c)\end{array}$} \\
\hline & & Injuries & Fatalities & Injuries & Fatalities \\
\hline Truck & 126,000 & 0.54 & 0.032 & 0.068 & 0.0040 \\
\hline Train (b) & 111,000 & 0.94 & 0.069 & 0.10 & 0.0077 \\
\hline TOTALS & & & & 0.17 & 0.012 \\
\hline
\end{tabular}

(a) Frequencies from Table F.3-3 in Appendix F.3.

(b) Train accident frequencies multiplied by 4 because the value in Table F.3-3 is per rail car and each train has four cars.

(c) Two significant figures shown for computational accuracy. 


\subsection{PROTECTIVE STORAGE MODE SAFETY ASSESSMENT}

The protective storage operations for decommissioning the FRP are divided into six major steps:

- planning and preparation

- chemical decontamination

- mechanical decontamination and fixing of residual contamination

- equipment deactivation

- isolation of contaminated areas

- final preparation for surveillance and maintenance

The procedures used in the above operations are presented in Section 7.4. Waste handling and transportation activities associated with the above protective storage operations are presented in Section 7.6.

For this safety analysis, the protective storage mode was divided into three major portions: (1) protective storage operations, (2) transportation, and (3) interim care.

\subsubsection{Protective Storage Operations Safety Assessment}

Protective storage operations for decommissioning the reference FRP were examined to evaluate the radiological and nonradiological safety impacts of both normal decommissioning operations and potential accidents.

\subsubsection{Radiological Safety Impacts of Protective Storage Operations}

The radiological effects of protective storage operations include the radiation dose to the public from radioactive effluents, occupational radiation exposure and the radiation dose to the public from potential accidental release of radioactive material.

\section{- Radiological Effects of Normal Protective Storage Operations}

Many of the procedures used in the protective storage decommissioning operations are identical to those used in the dismantlement mode. These include the chemical decontamination activities and use of selected physical decontamination methods. No major physical decontamination operations are done in protective storage. Table 8.4-1 lists estimates of the release of radioactive effluents and the resulting radiation doses from normal protective storage operations. The development of these release terms is shown in detail in Appendix F.2.1. The bases for the radiation dose calculations are given in Appendix F.4. 
TABLE 8.4-7. Estimated Radiation Dose to the Public from Release of Radionuclides During Normal Protective Storage Decommissioning Operations(a)

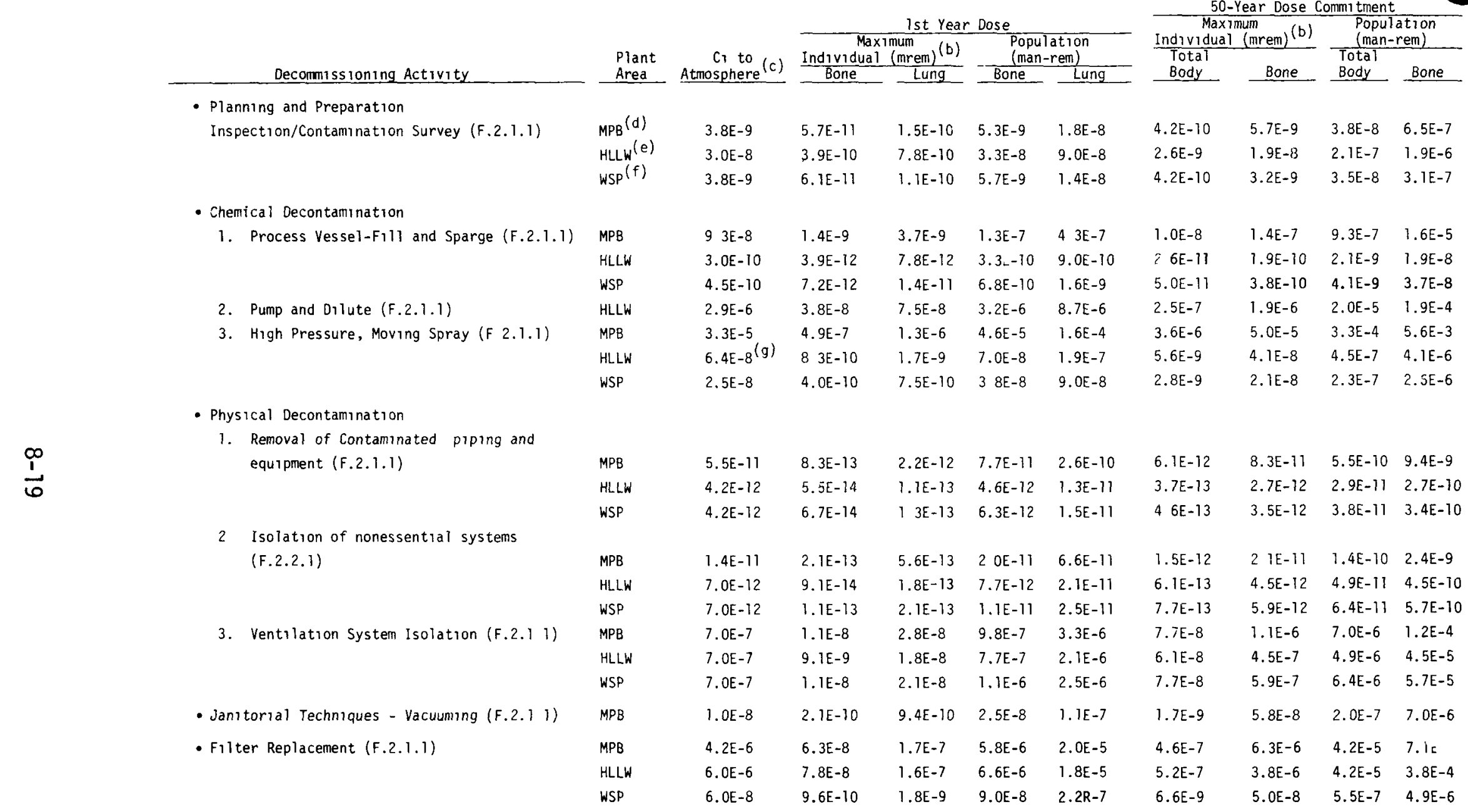

(a) Two significant figures shown for computational accuracy

(b) Maximum exposed individual is located one kilometer from the facility

(c) Release from 100 meter stack

(d) FRP Main Process Building

(e) High Level Liquid Waste Storage Area

(f) Waste Solidification Plant.

(g) Chemical decontamination of the WTEG/WTDC is used as the reference case 
Since no spray decontamination and equipment removal operations are performed in the high-level waste tanks, the operation with the highest release is the high-pressure-spray chemical decontamination of the FRP main process building. The radiation doses given in Table 8.4-1 are lower than those for the dismantlement mode and similarly are very small compared to natural background radiation exposure.

The occupational radiation exposure estimates for protective storage operations are given in Table 8.4-2. The information presented in this table is derived from Table F.2-3 in Appendix F.2.2 utilizing the decommissioning activities that are specific to protective storage operations. Most protective storage decommissioning operations are performed in FRP areas of low radiation levels and essentially no operations are performed in the highty contaminated zone: . The total estimated worker radiation exposure is 81 man-rem for protective storage operations.

TABLE 8.4-2. Estimated 0ccupational Radiation Dose from Protectjue Storage for all Decommissioning
Staff $(a)$

\begin{tabular}{|c|c|c|c|}
\hline Facility Area & Man-years & $\begin{array}{c}\text { Dose } \\
\text { man-rem }\end{array}$ & $\begin{array}{l}\text { Average Worker Dose } \\
\text { man-rem/quarter }\end{array}$ \\
\hline Main Process Building & 22.4 & 27.8 & 0.31 \\
\hline Liquid Waste Storage Area & 15.2 & 18.8 & 0.31 \\
\hline Waste Solidification Plant & 17.3 & 20.8 & 0.30 \\
\hline Fuel Receiving and Storage Area & 8.3 & 9.63 & 0.29 \\
\hline Auxiliaries & 2.8 & 3.7 & $\underline{0.33}$ \\
\hline Totals & 66 & 80.7 & $0.31^{(b)}$ \\
\hline
\end{tabular}


Radiological Effects of Potential Protective Storage Accidents

The protective storage procedures were examined and potential accidents were postulated that could lead to the release of radioactive materials. A wide spectrum of postulated accidents for decommissioning the reference FRP is given in Appendix F.2.1.2 along with the detailed calculations and assumptions for developing the estimates of the release terms. Table 8.4-3 lists the higher consequence postulated accidents for protective storage operations and the estimated radiation doses.

As seen from Table 8.4-3 the dominant accident identified is the failure of the first stage of HEPA filters during chemical decontamination in the main process building. The resulting radiation dose to the maximum individual is a first year dose of .006 mrem to the lung and a fifty year dose commitment of $0.12 \mathrm{mrem}$ to the bone. The radiation doses to the maximum exposed individual for the accidents postulated for the protective storage operations are smaller than those received from natural background radiation exposure.

\subsubsection{Nonradiological Safety Impacts of Protective Storage}

As with dismantlement, the primary nonradiation-related safety impacts of protective storage include the effect of chemical pollutants and construction/industrial-related lost-time injuries and fatalities.

- Potential Chemical Pollutants

The potential chemical pollutants from dismantlement operations are discussed in Section 8.3.1.2. As with dismantlement, chemical pollutants from protective storage operations do not pose a significant public hazard.

- Construction/Industrial Accidents

Table 8.4-4 provides estimates for potential worker injuries and fatalities from protective storage operations. As seen from the table, potentially 0.4 lost-time injuries and 0.003 fatalities could be expected to occur during the 2.5 years of protective storage operations. 
TABLE 8.4-3. Estimated Radiation Dose to the Public from Accidental Release of
Radionuclides During Protective Storage Decommissioning Operations

Accident

- Main Process Building

Mixing of Incompatible Chemicals

Fire in Ventilation During Welding

Filter Failure During Chemical Decontamination

- Liquid Waste Storage Area

Fire in Ventilation Duct During Welding

Filter Failure During Chemical Decontamination

- Waste Solidification Plant

Filter Failure During Chemical Decontamination

Fire in Ventilation Duct During Welding

Curies released
to atmosphere(c)

1st-Year Dose

Maximum Individual(b)

Bone (mrem)

Lung

50-Year Dose Commitment

Maximum Individual(b)

Bone (mrem)

Estimated

Frequency $(d)$

$\begin{array}{lllll}1.5 E-6 & 6.6 E-6 & 2.1 E-5 & 4.5 E-4 & 2.9 E-5\end{array}$

$1.8 \mathrm{E}-4$

$7.9 E-4$

$2.2 E-3$

$5.4 \mathrm{E}-2$

$3.4 E-3$

Medium

$4.0 E-4$

$1.8 \mathrm{E}-3$

$5.6 E-3$

1. $2 E-1$

7. $6 \mathrm{E}-3$

Medium

$1.8 E-4$

4. $3 E-4$

1. $5 E-3$

1. $7 E-2$

1. 7E-3

Medium

$1.2 E-5^{(e)}$

2. $9 E-5$

9. $7 E-5$

1. $1 E-3$

1. $1 E-4$

Medium

\section{5. $0 \mathrm{E}-6$}

1. $5 E-5$

4. $8 E-5$

6. $0 \mathrm{E}-4$

$5.5 E-5$

Medium

1. $8 E-4$

$1.7 E-3$

2. $2 E-2$

$2.0 \mathrm{E}-3$

Medium

(a) Two significant figures shown for computational accuracy.

(b) Maximum exposed individual is located at one kilometer from the facility.

(c) Release from 100 meter stack.

(d) High greater than $1 E-2$ per year; medium $1 E-2$ to $1 E-5$ per year; low less than $1 E-5$ per year.

(e) Waste tank equipment gallery/waste tank diverter cell chemical decontamination release used as source term. 
TABLE 8.4-4. Estimated Worker Lost-Time Injuries and Fatalities from Protective Storage Operations

\begin{tabular}{|c|c|c|c|c|c|}
\hline \multirow[b]{2}{*}{ Activity } & \multirow[b]{2}{*}{ Man-hr } & \multicolumn{2}{|c|}{$\begin{array}{c}\text { Frequency }(\mathrm{a}) \\
\text { Accidents } / 10^{6} \text { Man-hr }\end{array}$} & \multicolumn{2}{|c|}{$\begin{array}{c}\text { Occupational Safety } \\
\text { Accidents/Protective } \\
\text { Storage Operation }\end{array}$} \\
\hline & & $\begin{array}{l}\text { Lost-time } \\
\text { Injuries (b) }\end{array}$ & Fatalities & $\begin{array}{l}\text { Lost-time } \\
\text { Injuries(b) }\end{array}$ & Fatalities \\
\hline Heavy Construction & 8,200 & 10 & $4.2 E-2$ & 0.082 & $3.4 E-4$ \\
\hline Light Construction & 27,000 & 5.4 & $3.0 \mathrm{E}-2$ & 0.15 & $8.1 E-4$ \\
\hline Operations & 87,000 & 2.1 & $2.3 E-2$ & 0.18 & $2.0 \mathrm{E}-3$ \\
\hline Totals & 122,200 & & & 0.41 & $3.2 E-3$ \\
\hline
\end{tabular}

\footnotetext{
(a) Accident frequency data from Table F.2-5.

(b) Lost-time injuries are as defined in American National Standards Institute Method of Recording and Measuring Work Injury Experience - ANSI Z16.1-1967 (Revision of 216.1-1964).

(c) Two significant figures shown for computational accuracy.
}

\subsubsection{Protective Storage Transportation Safety}

Approximately one-sixth as many truck and rail shipments are required for protective storage as are required for dismantlement. Protective storage waste shipments include both truck and rail shipments of filter media and combustible and noncombustible trash, and rail shipments of vitrified decontamination liquids. Procedures and standards for the packaging and transport of radioactive wastes are discussed in Appendix F.3. The number of shipments and the type of packaging used for the transport of radioactive wastes from FRP protective storage operations are given in Section 7.6.

\subsubsection{Radiological Transportation Safety Impacts}

The radiological effects of protective storage transportation operations include the potential external radiation exposure of the transportation worker and the general public from normal transportation operations, and the radiation exposure to the public from the potential release of radioactive material from transportation accidents. 
- Radiological Effects of Normal Transportation Operations

Estimated routine radiation doses from rail and truck transport of radioactive wastes from FRP protective storage operations are shown in Tables 8.4-5 and 8.4-6. Dose calculations are based on maximum allowable dose rates for shipment in exclusive use vehicles and are therefore conservative. Information on the number of rail and truck shipments for protective storage and on shipping distances is taken from Section 7.6. Additional assumptions made in deriving estimated routine radiation doses are listed in Appendix F.3.

TABLE 8.4-5. Estimated Routine Radiation Dose from Rail Transport of Radioactive Wastes from FRP Protective Storage

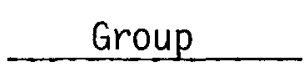

Brakeman

Onlookers

General Public
Dose per Rail Shipment (man-rem)

0.1

0.01

0.1
Total Radiation Dose for A11 Shipments (man-rem)

1

0.01

1

TABLE 8.4-6. Estimated Routine Radiation Dose from Truck Transport of Radioactive Wastes from FRP Protective Storage

Group

Truck Drivers

Garagemen

Onlookers

General Public
Dose per Truck Shipment (man-rem)

0.1

0.001

0.01

0.01
Total Radiation Dose for All Shipments, (man-rem)

2

0.02

0.2

0.2

As seen from Tables 8.4-5 and 8.4-6 the estimated routine radiation dose from protective storage transportation operations is 3 man-rem to the transportation workers and 1.4 man-rem to the general public. 
- Radiological Effects of Potential Transportation Accidents

Estimated frequencies, release quantities, and maximum individual radiation doses for selected accidents involving rail and truck transport of radioactive wastes from FRP protective storage operations are shown in Table 8.4-7. Accident severities are based on vehicle speed and fire duration as defined in Appendix F.3.2. Frequency calculations are based on probability data from Table F.3-2 combined with shipment data from Section 7.6. The radioactive inventories for each type of shipment and the radiation dose calculations are identical to those described in Section 8.3.2.1 for dismantlement transportation operations.

The estimated consequences of the postulated protective storage transportation accidents are the same as those for dismantlement. The frequency is smaller for protective storage because of the smaller number of shipments.

\subsubsection{Nonradiological Transportation Safety Impacts}

The primary nonradiation-related safety impacts for protective storage include the potential effect of chemical pollutants and nonradiation transportation accident injuries and fatalities.

- Potential Chemical Pollutants

The conclusion that chemical pollutants from dismantlement transportation operations do not pose a significant public hazard given in Section 8.3.2.2 applies to the protective storage transportation operations.

- Nonradiation Transportation Accident Injuries and Fatalities

Table 8.4-8 provides estimates for potential injuries and fatalities for protective storage transportation operations. As seen from the tabie, 0.03 potential injuries and 0.002 fatalities could be expected to occur as a result of protective storage transportation operations.

\subsubsection{Interim Care Safety Impacts of Protective Storage}

Following the completion of protective storage activities, the facility is placed in interim care. This time period is characterized by surveillance and maintenance activities designed to assure that the facility remains in a condition that poses minimum risks to the public. The activities included 
TABLE 8.4-7. Estimated Frequencies, Releases and Radiation Doses for Selected Accidents Involving Rail and Truck Transport of Radioactive Wastes from FRP Protective Storage

Accident Description

\section{Rail Transport}

Moderate severity accident with ATMX rail car

Severe accident with ATMX raij car

Moderate severity accident with cask

Severe accident with cask

Truck Transport

Minor accident with closed van

Moderate accident with closed van

Severe accident with closed van

\section{Frequency Accidents/} FRP Protective Storage

$1 \mathrm{E}-3$

$2 E-5$

$3 E-3$

$5 E-5$

$1 E-2$

$3 E-3$

TE-4

(a) Maximum exposed individual is assumed at 100 meters

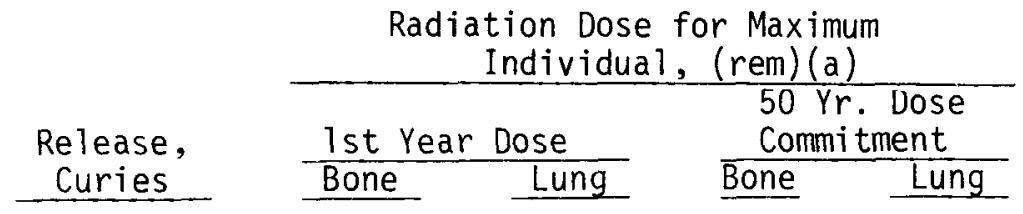

No Release

$2 E-4$

3. $3 E-3$

0.01

0.22

0.014

No Release

No Release

No Release

IE-4

$1.6 \mathrm{E}-3$

$5.2 E-3$

0.11

7. $1 \mathrm{E}-3$

$1 E-2$

0.16

0.52

11.2

0.71 
TABLE 8.4-8. Estimated Injuries and Fatalities from Protective Storage Trünsportation Accidents

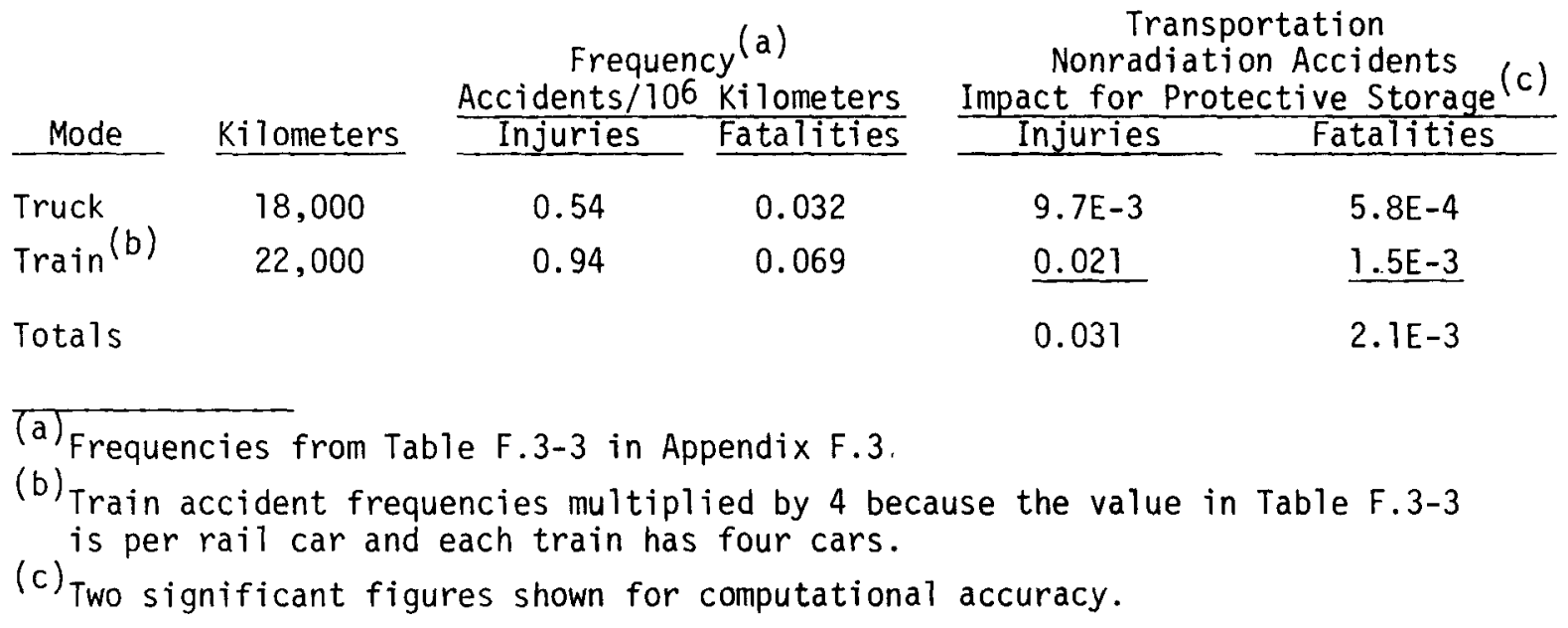

in this phase are monitoring and maintenance of operating safety systems, inspection and maintenance of physical barriers, and performing a radiation and environmental monitoring program.

This section examines the radiological and nonradiological safety impacts of interim care following protective storage. A discussion of the interim care operations following protective storage is presented in Section 7.4.7.

\subsubsection{Radiological Effects of Interim Care Activities}

Radiological effects of interim care activities include potential radionuclide releases from normal operations, occupational radiation exposure, and radionuclide releases from potential accidents.

- Radiological Effects of Normal Interim Care Activities

The release of radionuclides from normal interim care operations is expected to be negligible compared to those during the protective storage operations phase, Because of the rugged construction of the FRP plant areas that contain radioactivity, the erection of rigid barriers, and the surveillance and maintenance activities, radionuclide releases from normal interim care activities are expected to be extremely small and the radiological effects on the public would be negligible. 
The surveillance and maintenance staff will be exposed to the background radiation level of the FRP areas throughout the interim care period. During the interim care period the radiation will be continuously declining by radioactive decay. The inventory of radionuclides in the FRP at shutdown is given in Appendix $B$. For external radiation exposure, ${ }^{137} \mathrm{Cs}$ is the dominant isotope. Thus the external radiation levels are expected to reduce on the basis of an overall half-life of approximately 30 years. Table 8.4-9 gives estimated occupational radiation exposures at various time periods for interim care following protective storage. As seen from the table the accumulated radiation dose is estimated to be 1.8 man-rem after 10 years and 8.6 man-rem after 100 years.

TABLE 8.4-9. Estimated Occupational Radiation Doses from Interim Care Following Protective Storage

Interim Care

Time Period

First Year

10 Years

30 Years

100 Years
Surveillance and Maintenance Man-Years of Labor

$$
1.7
$$

17

51

170

\section{Accumulated Dose}

Man-Rem

0.2

1.8

4.4

8.6

\section{- Radiological Effects of Interim Care Accidents}

Chemical decontamination is performed in the FRP during the protective storage operations phase. Thus, the contamination remaining during interim care is fixed firmly in place and should not be readily available for entrainment. The FRP is almost entirely passive (no operating components except for monitoring systems) in the protective storage interim care period. Only low probability events with causes external to the plant (e.g., a large earthquake) or certain man-related events (e.g., abandonment of the facility or intrusion) appear to have the potential to release radioactive material. The combination of the low probability of the initiating events and the immobility of the FRP radionuclide inventory minimizes the effect of potential accidents during the interim care period. 


\subsubsection{Nonradiological Effects of Interim Care Activities}

Estimates of the expected number of injuries and fatalities to the surveillance and maintenance staff from industrial-related accidents is given in Table 8.4-10. As seen from the table, 0.8 lost-time injuries and 0.008 fatalities could be expected to occur after 100 years of protective storage interim care.

\section{TABLE 8.4-10. Nonradiological 0ccupational Accidents} During Protective Storage Interim Care

(a) Accident frequency rates from Table $F$ 2-5 in Appendix F.2

(b) Lost-time injuries are as defined in American National Standards Institute Method of Recording and Measuring Work Injury Experience - ANSI 216.1-1967 (Revision of 216 1-1964).

(c) Two significant figures shown for computational accuracy
}

\subsubsection{Safety Assessment of Deferred Dismantlement} Following Protective Storage

To obtain release of the site on an unrestricted basis, all radioactive materials above disposition criteria levels must be removed. Dismantlement of the facility following the interim care period is done using the techniques described in Section 7.3, with minor exceptions. Activities common to the dismantlement and protective storage modes are not repeated. A brief discussion of deferred dismantlement is given in Section 7.4.8.

This section examines the radiological and nonradiological safety impacts of final dismantlement operations following protective storage. The dismantlement operations and transportation activities are discussed separately. 


\subsubsection{Safety Effects of Final Dismantlement Operations Following Protective Storage}

The discussion of deferred dismantlement parallels that for immediate dismantlement. One principal difference is the elimination of the decommissioning activities common to both the immediate dismantlement and the protective storage modes. The second is the consideration of the decay of the radionuclides in the FRP. The amount of radioactivity and the radiation levels in the FRP will decrease during the interim care period.

- Radiological Effects of Final Dismantlement Operations

\section{Following Protective Storage}

A simplifying assumption is made that the radionuclide releases from normal operations and potential accidents for deferred dismantlement following an interim care period are identical to those for immediate dismantlement but are adjusted for radioactive decay.

Graphs showing the first-year and fifty-year radiation dose commitments to several organs in humans for various FRP radionuclide inventories as a function of time are given in Appendix F.4.4. The ratio of these values can be applied to the normal and accidental releases given in Section 8.3.1.1 to account for radioactive decay. Correction factors for the fifty-year dose commitment to the bone at various times are given in Table 8.4-11.

\section{TABLE 8.4-11. Correction Factors for Inhalation Radiation} Dose to Account for Radioactive Decay

Radionuclide Inventory in Plant Area Shown

Main Process Building

High-Level Liquid Waste Storage Area Waste Solidification Plant
Correction Factor for 50-Year Dose Commitment to Bone at Given Years After FRP Shutdown

0 Years 10 Years 30 Years 100 Years

1

0.9

0.7

0.5$$
1
$$

0.8

0.5

0.2

1

0.7

0.5

0.2 
As discussed in Section 8.4.3.1, external radiation exposure is expected to decrease at a rate approximating an overall half-life of 30 years. Consequently, if the identical dismantlement procedures are used in deferred dismantlement as were used in immediate dismantlement, the occupational radiation exposure will be reduced on the basis of an overall half-life of 30 years. This may not be true in cases where the procedures used in deferred dismantlement are changed to take advantage of the reduced radiation exposure levels.

In this study, for the case of deferred dismantlement after 10, 30, and 100 years, it is assumed that the procedures used are identical to those used in immediate dismantlement and the occupational exposure is reduced on the basis of an overall half-life of 30 years. It is assumed that the occupational dose from rebuilding and installing previously removed systems is small. Table 8.4-12 gives the estimated occupational radiation exposure for final dismantlement following protective storage. As seen from the table, the estimated occupational dose is 345 man-rem for final dismantlement operations after 10 years of protective storage and 43 man-rem after 100 years.

\begin{tabular}{|c|c|}
\hline ABLE $8.4-12$. & $\begin{array}{l}\text { Estimated Occupational Radiation } \\
\text { Exposures for Deferred Dismantlement } \\
\text { Following Protective Storage }\end{array}$ \\
\hline $\begin{array}{l}\text { Years After } \\
\text { FRP Shutdown }\end{array}$ & $\begin{array}{c}\text { Estimated Occupational } \\
\text { Exposure for Deferred } \\
\text { Dismantlement Activities } \\
\text { Man-Rem } \\
\end{array}$ \\
\hline 10 & 345 \\
\hline 30 & 216 \\
\hline 100 & 43 \\
\hline
\end{tabular}

- Nonradiological Effects of Final Dismantlement Following Protective Storage

Estimates of the expected number of injuries and fatalities from industrial/construction-related accidents for deferred dismantlement after protective storage are given in Table 8.4-13. As seen from the table, 1.5 lost-time injuries and 0.007 fatalities could be expected for deferred ismantlement after protective storage. 
TABLE 8.4-13. Estimated Worker Lost-Time Injuries and Fatalities for Deferred Dismantlement Following Protective Storage

\begin{tabular}{|c|c|c|c|c|c|}
\hline \multirow[b]{2}{*}{ Activity } & \multicolumn{3}{|c|}{$\begin{array}{c}\text { Frequency }(a) \\
\text { Accidents } / 10^{6} \text { Man-Hr }\end{array}$} & \multicolumn{2}{|c|}{$\begin{array}{l}\text { Occupational Safety } \\
\text { Accidents/Dismantlement }\end{array}$} \\
\hline & $\mathrm{Man}-\mathrm{Hr}$ & $\begin{array}{l}\text { Lost-Time }(\mathrm{b} \\
\text { Injuries } \\
\end{array}$ & Fatalities & $\begin{array}{l}\text { Lost-Time (b) } \\
\text { Injuries } \\
\end{array}$ & Fatalities \\
\hline Heavy Construction & 100,000 & 10 & $4.2 E-2$ & 1.0 & $4.2 E-3$ \\
\hline Light Construction & 96,000 & 5.4 & 3. $0 E-2$ & 0.52 & $2.9 E-3$ \\
\hline Operations & 3,200 & 2.1 & $2.3 E-2$ & $6.7 \mathrm{E}-3$ & $\underline{7.4 E-5}$ \\
\hline Totals & 200,000 & & & 1.5 & $7.2 E-3$ \\
\hline
\end{tabular}

\footnotetext{
(a) Accident frequency data from Table F.2-5.

(b) Lost-time injuries are as defined in American National Standards Institute Method of Recording and Measuring Work Injury Experience - ANSI 216.1-1967 (Revision of 216.1-1964).

(c) Two significant figures shown for computational accuracy.
}

\subsubsection{Transportation Safety for Deferred Dismantlement Following Protective Storage}

The deferred dismantlement transportation discussion parallels that for immediate dismantlement given in Section 8.3.2. As is the case for deferred dismantlement operations, the two principal differences are the elimination of transportation operations already performed for protective storage and the consideration of radioactive decay in the radiation doses.

- Radiological Effects of Final Dismantlement

Following Protective Storage Transportation Operations

The radiation dose from normal immediate dismantlement transportation operations is considered in Section 8.3.2.1. External radiation dose estimates were based on the maximum dose rates allowed by transportation regulations. As discussed in Section 8.4.4.1, the external radiation exposure is expected to decrease at a rate approximating an overall half-life of 30 years. Table 8.4-14 provides factors to obtain the external radiation doses from transportation operations after various times of interim care. Table 8.4-15 
provides the estimated truck and rail distances for immediate and deferred dismantlement. The factors given in Tables 8.4-14 and 8.4-15 can be used to adjust the values given in Section 8.3.2.1 for external radiation doses from normal immediate dismantlement transportation operations to apply to deferred dismantiement.

\section{TABLE 8.4-14. Correction Factors for External Radiation Doses from Normal Transportation Operations to Account for Radioactive Decay}

Time After FRP

Shutdown, Years Correction Factor

$\begin{array}{rl}0 & 1 \\ 10 & 0.8 \\ 30 & 0.5 \\ 100 & 0.1\end{array}$

TABLE 8.4-15. Estimated Truck and Rail Total Shipment Kilometers Immediate and Deferred Dismantlement After Protective Storage

\begin{tabular}{|c|c|c|c|}
\hline $\begin{array}{l}\text { Transportation } \\
\text { Mode }\end{array}$ & $\begin{array}{l}\text { Total Shipment } \\
\text { Kilometers } \\
\text { for Immediate } \\
\text { Dismantlement } \\
\end{array}$ & $\begin{array}{l}\text { Total Shipment } \\
\text { Kilometers } \\
\text { for Deferred } \\
\text { Dismantlement } \\
\end{array}$ & $\begin{array}{c}\text { Ratio of Deferred to } \\
\text { Immediate Dismantlement } \\
\text { Total Shipment } \\
\text { Kilometers }\end{array}$ \\
\hline Truck & 126,000 & 107,000 & .9 \\
\hline Train & 111,000 & 89,000 & .8 \\
\hline
\end{tabular}

The potential release of radioactive material and the resulting radiation doses from immediate dismantiement transportation accidents are discussed in Section 8.3.2.1. Utilizing the same assumptions for deferred dismantlement operations given in Section 8.4.4.1, Table 8.4-11 can be used to adjust the postulated transportation doses given in Section 8.3.2.1 to account for radioactive decay of the FRP inventory during the interim care period. The transportation accident frequencies should be adjusted by the ratios in Table 8.4-15. 
- Nonradioactive Effects of Final Dismantlement Following

Protective Storage Transportation Operations

Section 8.3.2.2 discusses the potential nonradiation transportation accident injuries and fatalities for immediate dismantlement. The ratios given in Table 8.4-15 are used to adjust the values to apply to deferred dismantlement.

\subsection{LAYAWAY MODE SAFETY ASSESSMENT}

The layaway operations for decommissioning the FRP are divided into the following five phases:

- planning and preparation

- chemical decontamination

- mechanical decontamination and fixing of residual contamination

- equipment deactivation

- final preparation for surveillance and maintenance.

The procedures used in the above operations are presented in Section 7.5. Waste handling and transportation activities associated with the above layaway operations are presented in Section 7.6.

For this safety analysis, the layaway mode was divided into three major portions: (1) layaway mode operations, (2) transportation, and (3) interim care.

\subsubsection{Layaway Operations Safety Assessment}

Layaway operations for decommissioning the reference FRP were examined to evaluate the radiological and nonradiological safety impacts of both normal decommissioning operations and potential accidents.

\subsubsection{Radiological Safety Impacts of Layaway Operations}

The radiological effects of layaway operations include the radiation dose to the public from radioactive effluents, occupational radiation exposure, and the radiation dose to the public from the potential accidental release of radioactive materials. 
Radiological Effects of Normal Layaway Operations

Many of the procedures used in the layaway decommissioning operations are identical to those used in the protective storage mode. Table 8.5-1 lists estimates of the releases of radioactive effluents and the resulting doses from normal layaway operations. No ventilation system isolation activities are performed during layaway operations and none of the FRP areas are isolated by the erection of barriers. Otherwise, the normal releases are identical to those for the protective storage mode, and the discussion given in Section 8.4.1.1 generally applies to layaway operations.

The occupational radiation exposure estimates for layaway operations are given in Table 8.5-2. The information presented in this table is derived from Table F.2-3 in Appendix F.2.2, utilizing the decommissioning activities that are specific to layaway operations. Most layaway decommissioning operations are performed in FRP areas with low radiation levels, and a minimal amount of operations are performed in the highly contaminated zones. The total estimated worker radiation exposure is 69 man-rem for layaway operations.

- Radiological Effects of Potential Layaway Accidents

The layaway procedures were examined and potential accidents were postulated that could lead to the release of radioactive materials. A wide spectrum of postulated accidents for decommissioning the reference FRP is given in Appendix F.2.1.2 along with the detailed calculations and assumptions for developing the estimates of the release terms. Table 8.5-3 1ists the higher consequence postulated accidents for layaway operations and the estimated radiation doses.

No ventilation system isolation and welding operations are performed in layaway operations. Otherwise, the accidents postulated in Table 8.5-3 are identical to those for the protective storage operations, and the discussion given in Section 8.4.1.1 for protective storage accidental releases applies to layaway operations. 
TABLE 8.5-1. Estimated Radiation Dose to the Public from Release of Radionuclides during Normal Layaway Decommissioning Operations $(a)$

\begin{tabular}{|c|c|c|c|c|c|c|c|c|c|c|c|}
\hline \multirow{3}{*}{\multicolumn{2}{|c|}{ Decommissioning Activity }} & \multirow[b]{3}{*}{$\begin{array}{l}\text { Plant } \\
\text { Area }\end{array}$} & \multirow[b]{3}{*}{$\begin{array}{c}\mathrm{C}_{1} \text { to } \\
\text { Atmosphere } \\
\text { Ac) }\end{array}$} & \multirow{2}{*}{\multicolumn{4}{|c|}{ 1st Year Dose }} & \multicolumn{4}{|c|}{ 50-Year Dose Commitment } \\
\hline & & & & & & & & \multirow{2}{*}{\multicolumn{2}{|c|}{$\begin{array}{c}\text { Maximum } \\
\frac{\text { Individual (mrem) }}{\text { Total }}\end{array}$}} & \multicolumn{2}{|c|}{$\begin{array}{l}\begin{array}{l}\text { Population } \\
\text { (man-rem) }\end{array} \\
\end{array}$} \\
\hline & & & & \multicolumn{2}{|c|}{$\begin{array}{l}\text { Maximum } \\
\text { Individual (mrem) } \\
\text { Bone }\end{array}$} & \multicolumn{2}{|c|}{$\begin{array}{l}\text { Population } \\
\text { (man-rem) }\end{array}$} & & & $\begin{array}{l}\text { Total } \\
\text { Body } \\
\end{array}$ & Bone \\
\hline \multicolumn{12}{|c|}{ - Planning and Preparation } \\
\hline \multirow{3}{*}{\multicolumn{2}{|c|}{ Inspection/Contamination Survey ( $F \quad 2 \quad 1 \quad i)$}} & $M P B(d)$ & 3 SE 9 & $57 E-11$ & $15 \mathrm{E}-10$ & $53 E-9$ & $18 \mathrm{E}-8$ & $42 E-10$ & $57 E-9$ & $38 \mathrm{E}-8$ & $65 \mathrm{E}-7$ \\
\hline & & HLLW $(e)$ & 3 OE-8 & $39 \mathrm{E}-10$ & $78 \mathrm{E}-10$ & $33 \mathrm{E}-8$ & $9 \mathrm{OE}-8$ & $26 \mathrm{E}-9$ & $19 E-8$ & $2 \mathrm{IE}-7$ & $19 E-6$ \\
\hline & & WSP $(f)$ & $38 \mathrm{E}-9$ & $61 E-11$ & $11 E-10$ & $57 \mathrm{E}-9$ & $14 E-8$ & $42 E-10$ & $32 \mathrm{E}-9$ & $35 \mathrm{E}-8$ & $31 E-7$ \\
\hline \multicolumn{12}{|c|}{ - Chemical Decontamination } \\
\hline \multirow{7}{*}{$\begin{array}{l}2 \\
3\end{array}$} & Process Vessel-F111 and Sparge ( $\left.\begin{array}{llll}F & 2 & 1 & 1\end{array}\right)$ & MPB & $93 E-8$ & $14 E-9$ & $37 \mathrm{E}-9$ & $13 E-7$ & $43 E-7$ & $10 \mathrm{E}-8$ & $14 \mathrm{E}-7$ & $93 \mathrm{E}-7$ & $16 \mathrm{E}-5$ \\
\hline & & HLLW & $30 E-10$ & $39 E-12$ & $78 E-12$ & $38 \mathrm{E}-10$ & $90 E-10$ & $26 \mathrm{E}-11$ & $19 E-10$ & $2 \mathrm{IE}-9$ & $19 \mathrm{E}-8$ \\
\hline & & WSP & $45 E-10$ & $72 \mathrm{E}-12$ & $14 \mathrm{E}-11$ & $68 \mathrm{E}-10$ & $16 E-9$ & $50 E-11$ & $38 \mathrm{E}-10$ & $4 \mathrm{IE}-9$ & $37 \mathrm{E}-8$ \\
\hline & Pump and Dilute $\left(\begin{array}{llll}F & 2 & 1 & 1\end{array}\right)$ & HLLW & $29 E-6$ & $38 E-8$ & $75 E-8$ & $32 E-6$ & $87 E-6$ & $25 E-7$ & $19 \mathrm{E}-6$ & $20 \mathrm{E}-5$ & $9 \mathrm{E}-4$ \\
\hline & High Pressure, Moving Spray ( $\left(\begin{array}{llll}2 & 2 & 1 & 1\end{array}\right)$ & MPB & $33 E-5$ & $49 E-7$ & $3 \mathrm{E}-6$ & $46 \mathrm{E}-5$ & $16 \mathrm{E}-4$ & $36 \mathrm{E}-6$ & $5 O E-5$ & $33 \mathrm{E}-4$ & $56 \mathrm{E}-3$ \\
\hline & & HLLW & $64 E-8(g)$ & $83 E-10$ & $7 \mathrm{E}-9$ & $70 E-8$ & $19 \mathrm{E}-7$ & $56 \mathrm{E}-9$ & $41 E-8$ & $45 \mathrm{E}-7$ & $41 E-6$ \\
\hline & & WSP & $25 E-8$ & $40 E-10$ & $75 E-10$ & $38 \mathrm{E}-8$ & $9 \mathrm{OE}-8$ & $28 \mathrm{E}-9$ & $21 \mathrm{E}-8$ & $23 E-7$ & $27 E-6$ \\
\hline \multicolumn{12}{|c|}{ - Physical Decontamination } \\
\hline \multirow{3}{*}{1} & equipment $\left(\begin{array}{llll}F & 2 & 1\end{array}\right)$ & MPB & $55 E-12$ & $83 E-13$ & $22 E-12$ & $77 \mathrm{E}-11$ & $26 \mathrm{E}-10$ & $61 E-12$ & $83 E-11$ & $55 E-10$ & $94 E-9$ \\
\hline & & HLLW & $42 \mathrm{E}-12$ & $56 \mathrm{E}-14$ & $11 E-13$ & $46 E-12$ & $13 \mathrm{E}-11$ & $37 \mathrm{E}-13$ & $27 E-12$ & $29 \mathrm{E}-11$ & $27 \mathrm{E}-10$ \\
\hline & & WSP & $42 E-12$ & $67 E-14$ & $13 \mathrm{E} 13$ & $63 E-12$ & $15 E-11$ & $46 \mathrm{E}-13$ & $35 \mathrm{E}-12$ & $38 \mathrm{E}-11$ & $34 \mathrm{E}-10$ \\
\hline \multicolumn{12}{|c|}{2 Isolation of nonessential systems } \\
\hline & $\left(\begin{array}{llll}F & 2 & 2 & 1\end{array}\right)$ & MPB & $14 E-12$ & $21 E-14$ & $56 \mathrm{E}-14$ & $2 O E-12$ & $66 \mathrm{E}-12$ & $15 E-13$ & $21 \mathrm{E}-12$ & $14 E-11$ & $24 \mathrm{E}-10$ \\
\hline & & HLLW & $70 \mathrm{E}-13$ & $91 \mathrm{E}-15$ & $18 E-14$ & $77 \mathrm{E}-13$ & $2 \mathrm{IE}-12$ & $61 E-14$ & $45 E-13$ & $49 E-12$ & $45 \mathrm{E}-11$ \\
\hline & & WSP & $70 \mathrm{E}-13$ & $11 E-14$ & $21 \mathrm{E}-14$ & $17 \mathrm{E}-12$ & $25 \mathrm{E}-12$ & $77 \mathrm{E}-14$ & $59 \mathrm{E}-13$ & $64 \mathrm{E}-12$ & $57 E-11$ \\
\hline - Jan & torial Techniques - Vacuuming (F 2 l 111$)$ & MPB & $1 \mathrm{OE}-8$ & $21 E-10$ & $94 \mathrm{E}-10$ & $24 E-8$ & $1 \mathrm{IE}-7$ & $17 \mathrm{E}-9$ & $58 \mathrm{E}-8$ & $20 \mathrm{E}-7$ & $70 E-6$ \\
\hline \multirow{3}{*}{\multicolumn{2}{|c|}{ - Filter Replacement ( $\left.\begin{array}{llll}2 & 2 & 1 & 1\end{array}\right)$}} & MPB & $42 E-6$ & $63 E-8$ & $17 E-7$ & $59 E-6$ & $2 O E-5$ & $46 \mathrm{E}-7$ & $63 \mathrm{E}-6$ & $42 E-5$ & $72 \mathrm{E}-4$ \\
\hline & & HLLW & $60 \mathrm{OE}-6$ & $78 \mathrm{E}-8$ & I $6 \mathrm{E}-7$ & $84 \mathrm{E}-6$ & $28 \mathrm{E}-5$ & $52 \mathrm{E}-7$ & $38 \mathrm{E}-6$ & $6 \mathrm{OE}-5$ & $10 \mathrm{E}-3$ \\
\hline & & WSP & 6 OE -8 & $96 \mathrm{E}-10$ & $18 \mathrm{E}-9$ & $90 E-8$ & $22 \mathrm{E}-7$ & $66 \mathrm{E}-9$ & $50 \mathrm{O}-8$ & $55 E-7$ & $49 \mathrm{E}-6$ \\
\hline
\end{tabular}

(a) Two significant figures shown for computational accuracy

(b) Maximum exposed individual is located one kilometer from the facility

(c) Release from 100 meter stack

(d) FRP Ma in Process Building

(e) High Level Liquid Waste Storage Area

(f) Waste Solidification Plant

$(g)$ Chemical decontamination of the WTEG/WTDC is used as the reference case 


\section{TABLE 8.5-2. Estimated Occupational Radiation Dose from Layaway for all Decommissioning Staff(a)}

\begin{tabular}{|c|c|c|c|}
\hline Facility Area & Staff Man-Years & Dose Man-Rem & $\begin{array}{l}\text { Average Worker } \\
\text { Man Rem/Quarter }\end{array}$ \\
\hline Main Process Building & 170 & 218 & 032 \\
\hline Liquid Waste Storage Area & 103 & 148 & 036 \\
\hline Waste Solidification Plant & 164 & 203 & 031 \\
\hline Fuel Recerving and Storage Area & 81 & 100 & 031 \\
\hline Auxiliaries & 14 & 157 & $0 \quad 28$ \\
\hline Totals & 532 & 685 & $032^{(b)}$ \\
\hline
\end{tabular}

\section{TABLE 8.5-3. Estimated Radiation Dose to the Public from Accidental Release of Radionuclides during Layaway Decommissioning Operations (a)}

Accident

- Main Process Burlding

Mixing of Incompatible Chemicals

Filter Fallure During Chemical

Decontamination

- Liquid Waste Storage Area Filter Fallure During Chemical Decontaminatıon

- Waste Solidification Plant Filter Fallure During Chemical Decontaminatior

Curies released
to atmosphere (c)

Ist-Year Dose Maximum Individual(b)

Bone (mrem)

50-Year Dose Commitment Maximum Individual(b)

(mrem) Estrmated

Bone Lung

Frequency $(d)$

$\begin{array}{llllll}15 \mathrm{E}-6 & 66 \mathrm{E}-6 & 2 \mathrm{IE}-5 & 45 \mathrm{E}-4 & 29 \mathrm{E}-5 & \text { High } \\ 40 \mathrm{E}-4 & 18 \mathrm{E}-3 & 56 \mathrm{E}-3 & 12 \mathrm{E}-1 & 76 \mathrm{E}-3 & \text { Medium }\end{array}$

$12 E-5^{(e)}$

$29 E-5$

$97 \mathrm{E}-5$

$11 E-3$

$1 \mathrm{IE}-4$

Medium

$50 E-6$

$6 O E-4$

$55 \mathrm{E}-5$

Medium

(a) Two significant figures shown for computational accuracy

(b) Maximum exposed individual is located at one kilometer from the facility

(c) Release from 100 meter stack

(d) High greater than $1 E-2$ per year, medium $1 E-2$ to $1 E-5$ per year, low less than $1 E-5$ per year

(e) Waste tank equipment gallery/waste tank diverter cell chemical decontamination release used as source term 


\subsubsection{Nonradiological Safety Impacts of Layaway}

As with dismantlement and protective storage, the primary nonradiationrelated safety impacts of layaway include the effect of chemical pollutants and construction/industrial-related lost-time injuries and fatalities.

- Potential Chemical Pollutants

The potential chemical pollutants from dismantlement operations are discussed in Section 8.3.1.2. As with dismantlement, chemical pollutants from layaway operations do not pose a significant public hazard.

- Construction/Industrial Accidents

Table 8.5-4 shows estimates for potential worker injuries and fatalities from layaway operations. As seen from the table, potentially 0.3 lost-time injuries and .002 fatalities could be expected to occur during the 2.3 years of layaway operations.

TABLE 8.5-4. Estimated Worker Lost-Time Injuries and Fatalities from Layaway Operations

\begin{tabular}{|c|c|c|c|c|c|}
\hline \multirow[b]{2}{*}{ Activity } & \multirow[b]{2}{*}{ Man-hr } & \multicolumn{2}{|c|}{$\begin{array}{c}\text { Frequency (a) } \\
\text { Accidents/106 Man-hr }\end{array}$} & \multicolumn{2}{|c|}{$\begin{array}{c}\text { Occupational Safety } \\
\text { Accidents/ (c) } \\
\text { Dismantlement }\end{array}$} \\
\hline & & $\begin{array}{l}\text { Lost-time } \\
\text { Injuries (b) }\end{array}$ & Fatalities & $\begin{array}{l}\text { Lost-time } \\
\text { Injuries (b) }\end{array}$ & Fatalities \\
\hline Heavy Construction & 0 & 10 & $4.2 E-2$ & -- & -- \\
\hline Light Construction & 12,000 & 5.4 & $3.0 \mathrm{E}-2$ & 0.065 & $3.6 \mathrm{E}-4$ \\
\hline Operations & 86,000 & 2.1 & $2.3 E-2$ & 0.18 & $2.0 \mathrm{E}-3$ \\
\hline Totals & 98,000 & & & 0.25 & $2.4 \mathrm{E}-3$ \\
\hline \multicolumn{6}{|c|}{$\begin{array}{l}\text { (a) Accident frequency data from Table F.2-5. } \\
\text { (b) Lost-time injuries are as defined in American National Standards Institute } \\
\text { Method of Recording and Measuring Work Injury Experience - ANSI Z16.1-1967 } \\
\text { (Revision Of Z16.1-1964). }\end{array}$} \\
\hline
\end{tabular}




\subsubsection{Layaway Transportation Safety}

The layaway transportation operations are essentially identical to those of the protective storage decommissioning mode discussed in Section 8.4.2.

\subsubsection{Interim Care Safety Impacts of Layaway}

Following completion of layaway activities, the facility is placed in a period of surveillance and maintenance designed to assure that it remains in a condition that poses minimum risks to the public. This phase includes routine inspections, preventive and corrective maintenance on operating equipment and a regular program of radiation, effluent, and environmental monitoring. The status of all safety-related equipment is monitored continually during the surveillance period.

This section examines the radiological and nonradiological safety impacts of interim care operations following layaway of the FRP. A discussion of the interim care operations following layaway is presented in Section 7.5.7.

\subsubsection{Radiological Effects of Layaway Interim Care Activities}

Radiological effects for interim care activities include potential radionuclide releases from normal operations, occupational radiation exposure, and radionuclide releases from potential accidents.

- Radiological Effects of Normal Layaway Interim Care Activities

As discussed in Section 8.4.3.1, the releases of radionuclides from normal interim care activities are expected to be negligible.

The operations, surveillance, and maintenance staff will be exposed to the background radiation level of the FRP areas throughout the layaway interim care period. The background discussion given in Section 8.4.3.1 also applies to layaway interim care occupational exposure. Table 8.5-5 gives the estimated occupational radiation exposures for various time periods of layaway interim care. As seen from the table, the accumulated radiation dose is estimated to be 12.8 man-rem after 10 years and 61.4 manrem after 100 years. 
TABLE 8.5-5. Estimated Occupational Radiation Doses

for Interim Care Following Layaway

\begin{tabular}{cccc}
$\begin{array}{c}\text { Layaway Interim Care } \begin{array}{c}\text { Time Period } \\
\text { Years }\end{array} \\
y\end{array}$ & $\begin{array}{c}\text { Operating, Surveillance, } \\
\text { and Maintenance Labor } \\
\text { Man-Years }\end{array}$ & $\begin{array}{c}\text { Accumulated Dose } \\
\text { Man-Rem }\end{array}$ \\
\cline { 2 - 3 } 1 & 8 & 1.4 \\
30 & 80 & 12.8 \\
100 & 240 & 31.4 \\
& 800 & 61.4
\end{tabular}

\section{- Radiological Effects of Interim Care Following Layaway}

As discussed for protective storage in Section 8.4.3.1, the combination of the low probability of potential initiating events that could release substantial amounts of radioactivity and the relative immobility of the radionuclide inventory minimizes the effect of potential accidents during the layaway interim care period.

\subsubsection{Nonradiological Effects of Layaway Interim Care Activities}

Estimates of the expected number of injuries and fatalities to the operating, surveillance, and maintenance staff from industrial accidents is given in Table 8.5-6. As seen from the table, 4 lost-time injuries and 0.04 fatalities could be expected to occur after 100 years of interim care following layaway.

\subsubsection{Safety Assessment of Deferred Dismantlement Following Layaway}

To release the site for unrestricted use, all radioactive material above disposition criteria levels must be removed. Dismantlement of the facility following interim care will be carried out using the techniques described in Section 7.3, with minor exceptions. Activities common to both the dismantlement and 1ayaway modes will not be repeated. A brief discussion of deferred dismantlement following layaway is given in Section 7.5.8.

The safety impacts of deferred dismantlement operations after protective storage and after layaway are very similar. Small differences are believed to be within the uncertainty and the assumptions that were made in Section 8.4.4. The safety impacts identified in Section 8.4.4 are assumed to apply to deferrad dismantlement operations following layaway. 


\section{TABLE 8.5-6. Nonradiological Occupational Accidents during Layaway}

Interim Care

\begin{tabular}{|c|c|c|c|c|c|c|c|c|c|}
\hline \multirow{3}{*}{ Operation } & \multirow{3}{*}{$\begin{array}{l}\text { Estimated } \\
\text { Man-Hr/Yr }\end{array}$} & \multirow{2}{*}{\multicolumn{2}{|c|}{$\begin{array}{c}\text { Frequency }(\mathrm{a}) \\
\text { No. Accidents/ } \\
106 \mathrm{Man}-\mathrm{Hr}\end{array}$}} & \multicolumn{6}{|c|}{$\begin{array}{c}\text { Occupational Safety } \\
\text { No. Accidents/Surveillance Period (c) }\end{array}$} \\
\hline & & & & & lears & 30 & ears & 100 & Years \\
\hline & & $\begin{array}{l}\text { Lost-Time(b) } \\
\text { Injuries }\end{array}$ & Fatalities & Lost-Time & Fatalities & Lost-Time & Fatalities & Lost-Time & Fatalities \\
\hline Surveillance ${ }^{(a)}$ & 14,000 & 2.1 & $2.3 \mathrm{E}-2$ & 0.29 & $3.2 E-3$ & 0.88 & $9.7 \mathrm{E}-3$ & 2.9 & $3.2 E-2$ \\
\hline Maintenance & 2,000 & 5.4 & $3.0 E-2$ & 0.11 & $6.0 E-4$ & 0.32 & $1.8 \mathrm{E}-3$ & 1.1 & $6 E-3$ \\
\hline $\begin{array}{l}\text { Accumulated Total } \\
\text { for Time Period }\end{array}$ & & & & 0.40 & $3.8 \mathrm{E}-3$ & 1.2 & $1.2 \mathrm{E}-2$ & 4.0 & $3.8 E-2$ \\
\hline $\begin{array}{l}\text { (a) Accident Freque } \\
\text { (b) Lost-time injur } \\
\text { Method of Recor } \\
\text { (Revision of } \mathrm{Zl} \\
\text { (c) TWo significant }\end{array}$ & $\begin{array}{l}\text { cy Rates fr } \\
\text { es are as c } \\
\text { ing and Mea } \\
.7-1967) \\
\text { figures sho }\end{array}$ & $\begin{array}{l}\text { Table F.2- } \\
\text { ined in Ame } \\
\text { ring Work I } \\
\text { for comput }\end{array}$ & $\begin{array}{l}\text { an Nation } \\
\text { rry Experi } \\
\text { ional accur }\end{array}$ & $\begin{array}{l}\text { Standards } \\
\text { e - ANSI Z }\end{array}$ & $\begin{array}{l}\text { nstitute } \\
6.1-1967\end{array}$ & & & & \\
\hline
\end{tabular}


ฯ 


\subsection{COMPARISON OF ALTERNATIVE DECOMMISSIONING APPROACHES}

The alternative courses of action that can be taken in decommissioning a fuel reprocessing plant have been identified and defined in Section 3 and have been examined in detail in Section 7. The purpose of this section is to identify and compare the key parameters to use in making a choice between these decommissioning alternatives.

\subsection{PARAMETERS FOR USE IN COMPARISON OF ALTERNATIVES}

A major parameter for comparison is the cost. Which decommissioning approach will minimize the direct cost of the undertaking to the facility owner and alternately to the electrical power consumer? This question can not be answered easily because the expenditure of funds may be distributed over time periods ranging in length from 5 years to perhaps over 100 years, and some means must be devised to permit evaluation of these expenditures on a common basis.

One approach is to compute and sum up the present dollar values of all of the future expenditures for each decommissioning alternative, and compare these sums. The present value of a future expenditure of money is given by:

$$
P_{b}=\frac{S_{b}}{(1+k)^{b}}
$$

where

$P_{b}$ is the present value of an expenditure $S_{b}$ made $b$ years from now, with $k$ being the discount rate appropriate for the corporation involved. Definitions of discount rate, interest rate, and inflation rate together with rationale for selecting certain values of these rates are given in Appendix G. Thus, in the case of immediate dismantlement, the present value cost of that alternative is given by:

$$
P_{D}=\sum_{a=1}^{n} \frac{D_{a}}{(1+k)^{a}}
$$

where $D_{a}$ is the estimated dismantlement cost, in current dollars, for the $a^{\text {th }}$ year. This expression is valid only when there is no inflation. When 
inflation is included, the present value cost becomes:

$$
P_{D}=\sum_{a=1}^{n} \frac{D a(1+j)^{a}}{(1+k)^{a}}
$$

where $j$ is the annual inflation rate.

For the case of layaway or protective storage with deferred dismantlement, the present value cost is given by:

$$
P_{L D}=\sum_{a=1}^{1} \frac{L a(1+j)^{a}}{(1+k)^{a}}+\sum_{b=\ell}^{m} S_{b} \frac{(1+j)^{b}}{(1+k)^{b}}+\sum_{c=m}^{n} D c \frac{(1+j)^{c}}{(1+k)^{c}}
$$

where La is the estimated layaway cost, in current dollars, for $a^{\text {th }}$ year.

$S_{b}$ is the estimated maintenance and surveillance cost, in current dollars, for the $b^{\text {th }}$ year; and

$D_{C}$ is the estimated dismantlement cost, in current dollars, for the $c^{\text {th }}$ year.

The layaway effort takes place over years 1 to $\ell$, the maintenance and surveillance effort takes place over years $\ell$ to $m$, and the deferred dismantlement takes place over years $m$ to $n$.

A similar expression applies for the case of protective storage, with La replaced by $\mathrm{Pa}$, the protective storage cost, in current dollars, for the $a^{\text {th }}$ year.

The present value approach is useful for comparisons over the near future (1-20 years), but becomes less meaningful for time periods approaching 100 years. For example, the present value of one dollar expended 50 years from now, with a discount rate of $10 \%$ and no inflation, is less than one cent. Thus, it always appears advantageous to delay major expenditures as long as possible when using uninflated present values for comparisons.

Another parameter of interest is the amount of land committed and for how long. This parameter is related to cost in that the land occupied by a retired 
nuclear facility has a finite value that cannot be realized as long as it cannot be used for other purposes. This value depends on the assessed value of the land and the need of the owner for such property during the time period under consideration. Basically, the value of the property is just what it would cost the owner to obtain a comparable property, or what he could receive if he sold the property. Consideration must also be given to the cost of property taxes and liability insurance on the retired facility during any interim care period.

Other key parameters for consideration are:

1) the value of materials expended or recovered,

2) the amount of labor expended,

3) the amount of occupational radiation exposure received by the decommissioning work force,

4) the potential for radiation exposure to the general public as a result of selecting a particular decommissioning approach,

5) the potential for industrial accidents during the decommissioning effort, and

6) the impact (cultural and aesthetic) of the decommissioning program on the surrounding community.

Items (1) and (2) are implicitly included in the total cost calculations. No universally accepted method has been developed for relating occupational radiation exposure to dollar values. Therefore, in these comparisons of decommissioning approaches, the As Low As Reasonably Achievable doctrine will prevail as the criterion. Similarly, the radiation exposure to the public as a result of decommissioning activities should be kept low. The decommissioning approach that minimizes the probability and the consequences of industrial accidents and injuries is, of course, the desirable approach to take. The cultural and aesthetic impacts of the decommissioning activities on the surrounding community are very difficult to quantify, and no attempt is made to do so. These latter impacts are mentioned only to point out that social 
pressures may be brought to bear on the facility owner by the community to complete the decommissioning program (including deferred dismantlement) at the earliest feasible time.

\subsection{COMPARISON OF ALTERNATIVE APPROACH PARAMETERS}

The values of the quantifiable parameters, as estimated in this study, are given in Table 9.2-1. As indicated in Section 9.1, some of these parameters are not easily relatable to each other. It seems clear that if one decommissioning approach resulted in minimizing all of these parameters simultaneously, that approach would be the most desirable choice. Unfortunately this condition does not occur, and a certain amount of subjectivity is unavoidable when deciding which parameters are most important for selecting a decommissioning approach.

The time distribution of expenditures for the various decommissioning alternatives are illustrated in Figure 9.2-1 where the accumulated costs are plotted as a function of the time after facility shutdown. Deferred dismantlement is shown to take place after 10,30 and 100 years. The costs shown are in constant 1975 dollars. These same costs are converted to present value costs and are displayed in Figure 9.2-2, for an assumed inflation rate of $6 \%$ and discount rate of $10 \%$. This latter figure clearly illustrates why it appears economically advantageous, when using present value cost comparisons, to delay expenditures as far into the future as possible.

Figure 9.2-1 also shows that it is not cost effective to place a facility in layaway for more than about ten years, since the total layaway costs exceed the total protective storage costs beyond that time.

\subsection{CONCLUSIONS}

It seems likely that non-technical and non-economic factors, which are not within the scope of this study, will determine actual decommissioning schedules, and that these schedules will require dismantlement in the 10-30 year time frame. However, if the preceeding conjecture is ignored and an examination of technical results in Table 9.2-1 and Figures 9.2-1 and 9.2-2 is made, one is lead to the following conclusions: 
TABLE 9.2-1. Values of Parameters for Alternative Decommissioning Approach Comparisons

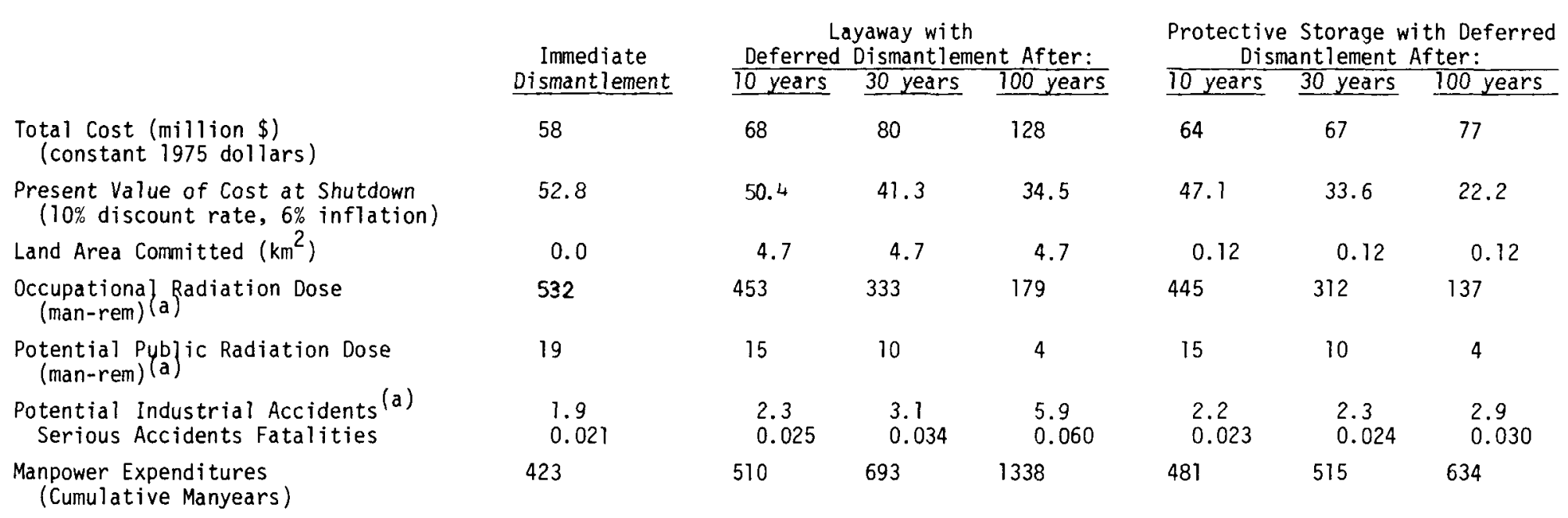

(a) Includes decomissioning operations, interim care, and transportation where applicable. 


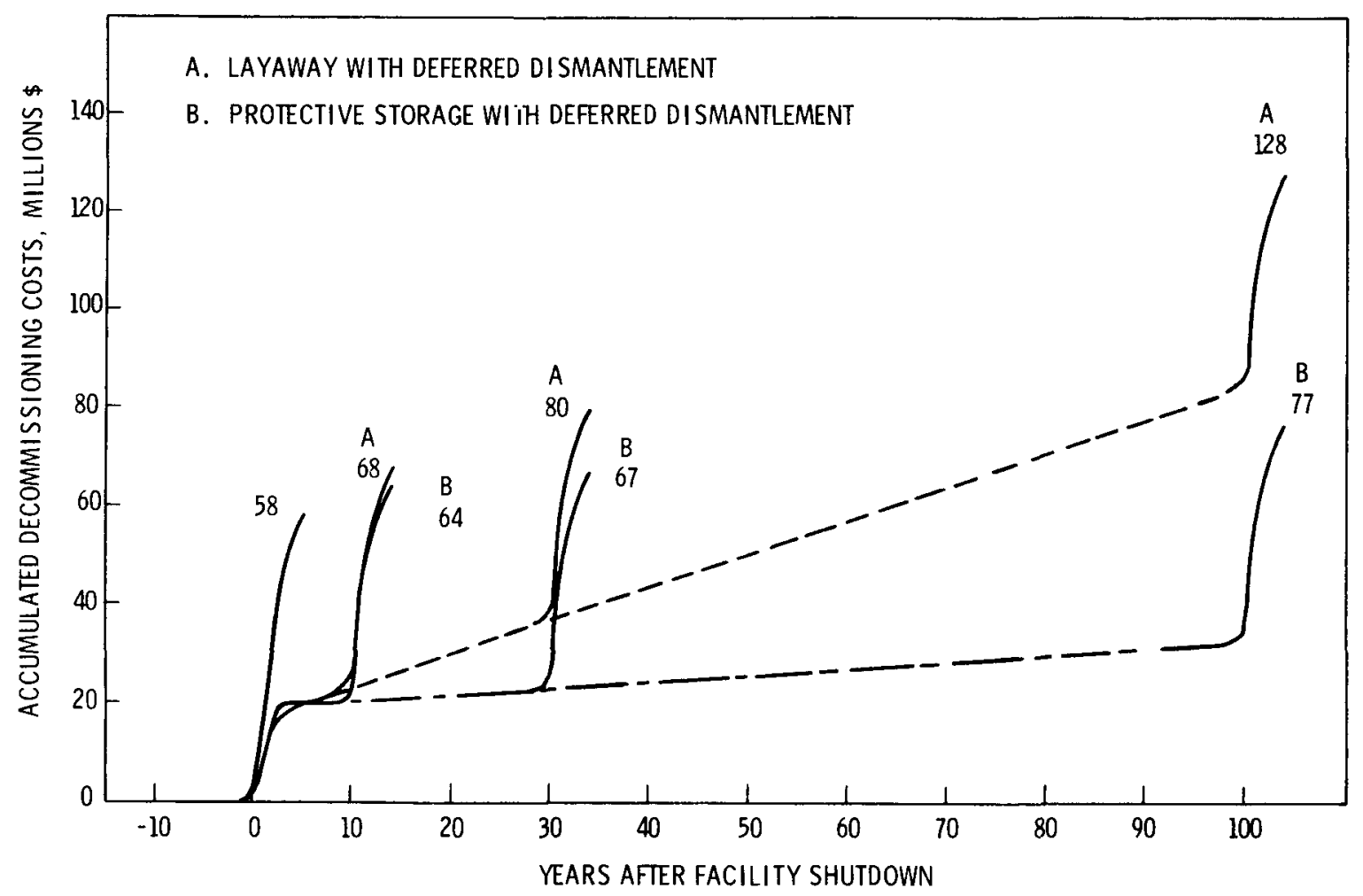

FIGURE 9.2-1. Accumulated Decommissioning Costs in Constant 1975 Dollars

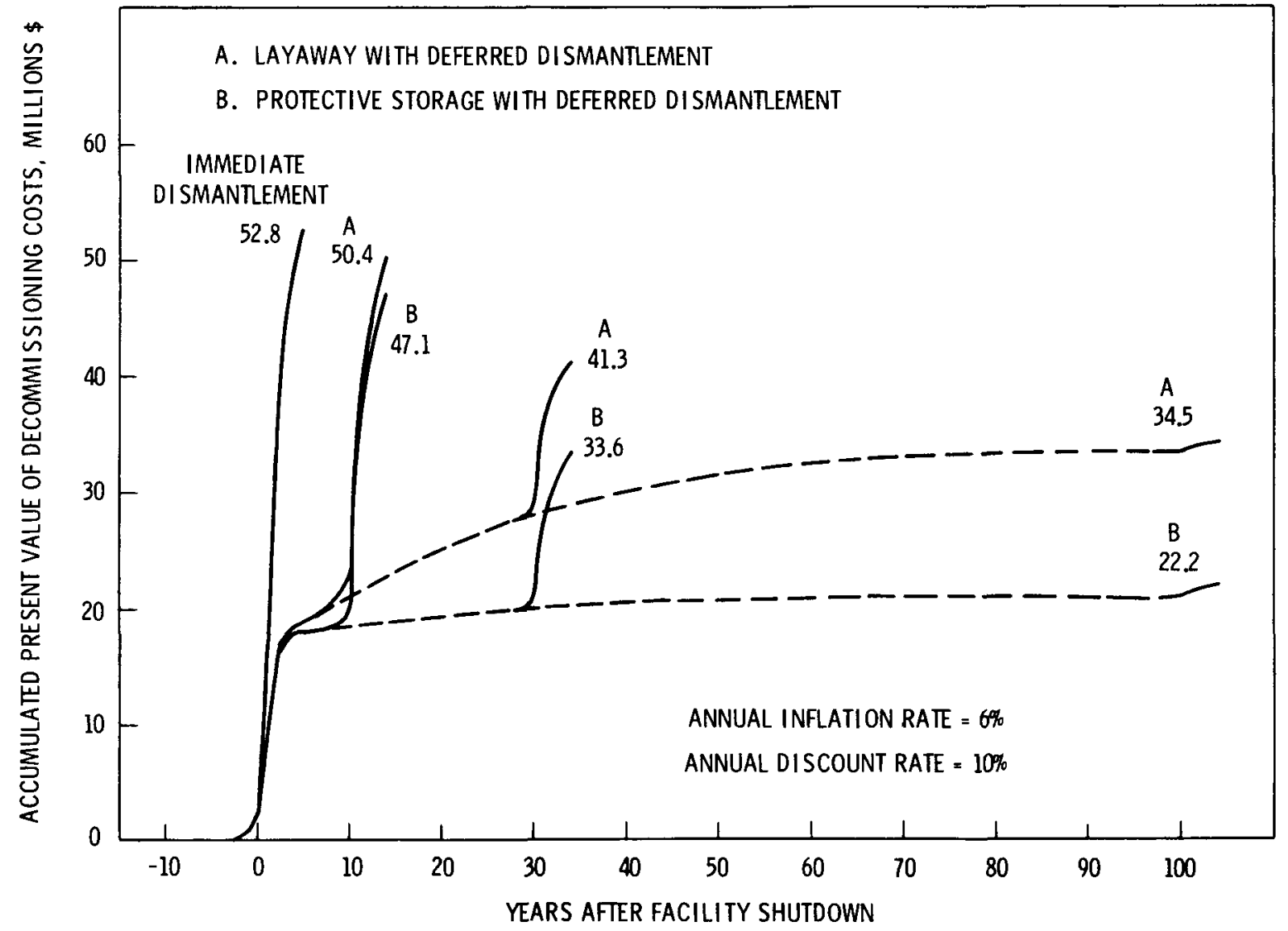

FIGURE 9.2-2. Accumulated Present Value of Decommissioning Costs, Adjusted for Inflation 
(1) Immediate dismantlement is more costly (in present value cost) and requires more occupational radiation dose than any other option, and would probably not be selected for implementation unless the site was needed badly for other use or unless socio-political pressures become the governing factor. (2) Layaway is probably a better choice than protective storage if dismantlement is scheduled to take place within 10 to 12 years after the facility has been shutdown.

(3) Protective storage is a better choice than layaway if dismantlement is scheduled to take place more than 10 to 12 years after the facility has been shutdown.

(4) Deferring the dismantlement effort for as long as possible results in the occupational radiation dose and the present value of cost being steadily reduced with time. Unfortunately, the approximately 30 year half-life of the residual radionuclide inventory deposited throughout the plant is too long to achieve large reductions in occupational radiation dose via decay of the radionuclides in time spans that are comparable with lifetimes of our institutional and governmental agencies. 


\subsection{ALTERNATIVE APPROACHES TO FINANCING DECOMMISSIONING}

The purpose of this section is to identify alternative approaches to financing the decommissioning of nuclear fuel cycle facilities and preliminarily examine the relative advantages and disadvantages of the approaches.

It is assumed, for this discussion, that the owners and/or operators of a nuclear facility will be responsible for the decommissioning costs. If the federal government were to pay all costs, whether or not it owned the facility, the financing problem would be simplified, but the solution may not be acceptable to taxpayers and their elected representatives who did not benefit from the operation of the nuclear facility.

Before discussing the available financing approaches, it is useful to first identify the ownership possibilities for fuel cycle facilities. The four basic categories of ownership are: publicly-owned utilities, investorowned utilities, nonutility corporations, and government (federal or state). Ownership combinations within each category are common (e.g., often several public or several investor-owned utilities will jointly own a nuclear power plant). Ownership combinations by entities within different categories are generally rare, al though joint ownership of power reactors by combinations of public and investor-owned utilities is no longer uncommon. Current fuel reprocessing plants in the U.S. are owned by nonutility corporations.

The principal options for funding decommissioning activities are: pay the costs when they are incurred, (2) establish a sinking fund that will be increased by annual payments during a facility's expected life which can then be used to pay decommissioning costs, and (3) collect the present value of the estimated future decommissioning costs before the facility begin to operate, a pre-payment sinking fund. Various combinations of these options could also be utilized.

The first option, paying costs when they are incurred, is clearly the simplest choice. No separate entity is needed to collect and disburse funds. Facility owners would treat decommissioning costs as an additional expense in the year the costs are incurred. These costs would probably be funded through 
the corporation's long-term debt structure. The second option, estabiishment of an annual payment sinking fund sufficient to cover all decommissioning costs, would assure that adequate funds were available when needed assuming no premature facility shutdown. The third option, pre-payment of the present value of the anticipated decommissioning costs into a single payment sinking fund, would assure that adequate funds were available even if the facility should terminate operations prematurely.

\subsection{OPTION I: PAYMENT OF COSTS UHEN INCURRED}

Delaying the commitment of funds for paying decommissioning costs until the work actually takes place has several disadvantages from the viewpoint of protecting the public safety and the public coffers. The first problem may be that of getting the obligated party to actually perform the work and pay the costs. If legal proceed is $t$ :came necessary to fix responsibility, many additional years and dollars could be expended in achieving that determination. Even if the owner's responsibility is established and accepted, the owner may not have sufficient financial strength to pay for the work, i.e., the corporation might be in bankruptcy or be otherwise financially incapacitated. This problem is not too likely to occur if the facility owner is a regulated utility since presumably the state public utility commission will consider decommissioning as a legitimate operating expense and allow appropriate rate adjustments to pay these expenses. Similarly, if the facility is owned by a governmental body, the necessary funds can be raised through that body's taxing authority.

One solution to this problem would be to require any corporation planning to build and operate a nuclear facility to purchase a surety bond or an insurance policy which would assure the availability of adequate funds for decommissioning when needed. This approach is not unprecedented in that many states require bonds from coal-mining companies to ensure reclamation of strip-mined land. It is complicated in the case of nuclear facilities due to the large amount of money involved and the long time span from startup to shutdown (in the order of 30 years). There is some uncertainty whether or not a sufficiently solvent and stable surety could be found to assure payment of the decommissionins 
xpenses. An alternative to individual bonds or insurance policies for the operating corporations could be an insurance pool analogous to the three insurance pools established in 1956 to provide liability and property damage insurance for commercial nuclear power reactors. Because the pool would have many members, an individual bankruptcy would not materially impair the ability of the pool to pay a claim.

One additional problem with the Pay When Incurred option is that it is inequitable to those future rate payers or taxpayers who will have to pay the decommissioning costs for a facility without having enjoyed the benefits of that facility's operation. While such intergenerational subsidies are not unknown in the U.S., (a) it is arguably more equitable to require that those who enjoy the products of the nuclear facilities also bear the decommissioning expenses.

\subsection{OPTION II: CREATION OF AN ANNUAL PAYMENT SINKING FUND}

One alternative to paying decommissioning costs as they are incurred is the establishment of an annual payment sinking fund to generate enough funds during the life of a facility to pay these anticipated costs. Separate sinking funds could be established for each fuel cycle facility. Alternatively, each organization might have a single fund to cover all its facilities.

The sinking fund could be set up by estimating future costs in current dollars of the year of facility startup. An amount would be paid into the fund per unit of product so that the payments, plus compound interest earned by investing the fund during and after the plant's operating life, would be sufficient to pay all anticipated decommissioning expenses.

The annual payments into the sinking fund should increase at the same rate that the estimated costs increase. Reestimating this cost in detail each year would be tedious. An escalation index weighted to reflect the percentage

(a) One example of an intergenerational subsidy is the social security system. Certain persons who had little or no opportunity to earn work credits are still eligible for benefits. Workers who began their working career after the social security system was initiated are not eligible for this special benefit. 
of labor and materials required can perhaps be constructed to update the cost estimate for the decommissioning activities. Alternatively, a proxy index such as a construction cost escalation index can probably be used.

The alternative to increasing the annual payment with cost escalations is to provide for a constant annual payment into the sinking fund. Although this alternative facilitates bookkeeping and computations, it is inequitable for consumers during early years of the facility's lifetime. Later consumers would be making the annual payment in cheaper dollars unless the U.S. economy returns to a period of deflation.

In reality, the annual sinking fund payment will have to be changed regularly, probably every year, to account for factors other than expected escalation of the decommissioning costs. This is true because the many variables that are used to calculate the required annual payment will change with time. For example, the expected rate of cost escalation and the rate-ofreturn achieved by the fund stewards will most certainly change. The load factor for the facility will not be completely constant over time. The ultimate decommissioning cost can also be expected to change over time because of technological innovations and new regulatory requirements. It is also likely that the expected life of a plant will change. All of these changes can be periodically accounted for by adjustments in the annual payment to the sinking fund. If such changes are reflected annually in the sinking fund payment, the value of the sinking fund should be close to the needed funds when the facility is retired. The procedure for calculating annual sinking fund payments plus some illustrative calculations are shown in Appendix G.

A variety of entities could be designated to provide stewardship for the sinking fund. Possibilities include state government, the federal government, or a private organization such as a bank. An independent "Decommissioning Assurance Agency" could also be chartered by each state or by the federal government to retain and invest the sinking fund and perhaps oversee activities and disperse payments to those conducting the activities. Such an agency would act in a fiduciary capacity for the public. Its governing board might be composed of representatives of the public, government, power-consuming 
industries, and power-producing industries. By including various interest groups, tendencies to overestimate or underestimate costs and the annual payments needed to fund the costs should be minimized.

One advantage of the annual payment sinking fund approach is that it should help to ensure that decommissioning activities actually occur. When funds set aside to cover decommissioning expenses, the question of who should pay the expenses is alleviated and arguments about responsibility are less likely to occur.

A second important advantage of the Annual Payment Sinking Fund option is that it should encourage desirable economic choices when power generating options are being considered by a utility. Currently, future decommissioning and waste management costs are hardly reflected in the electricity prices paid by consumers. If all nuclear fuel cycle facilities were required to create sinking funds to provide for future decommissioning and waste management expenses, their anticipated costs would be passed on and be reflected in the utilities' and consumer's power bills. Presumably utilities would be influenced to incorporate these costs when selecting, for example, between nuclear and coal-fired thermal power plants.

A final advantage of the sinking fund approach is that it is equitable. If a cost escalation indexing approach is utilized, all consumers should pay their approximately proportional share of costs in constant dollars. Exact sharing of costs would be virtually impossible because of changes in the operational life of facilities and changes in expected decommissioning cost caused by technological innovation and/or new regulatory requirements.

Several potential difficulties associated with the sinking fund option should be recognized. The first of these relates to the care and investment of the fund itself. Professional management of the fund would be required. Controls on the investments made by the fund would also be desirable. Perhaps the fund could be limited to investment in federal notes and bonds, and state or private bonds with sufficiently high rating, e.g., AA or higher. The fund steward will be faced with the same problem other investors are: i.e., how can assets be invested to earn a return that at least matches the rate of 
inflation? If the fund is not able to match inflation, the payments to the fund (in year of startup dollars) will have to be increased over time at a rate which exceeds the rate of inflation. The possibility of such an increase would have to be initially acknowledged by all parties.

The sinking fund would probably have to be made subject to the control of some type of board of trustees. The size, composition, and method of designating such a board would undoubtedly be controversial.

It must also be recognized that establishment and control of a sinking fund would, by its nature, create more administrative complexity and problems in general than the pay-when-expenses-are-incurred approach. In addition to the problems of fund management and control, the existing fund could result in an additional government or quasi-government agency to oversee the operation of the numerous fuel cycle facility sinking funds.

A final potential problem with the sinking fund approach is that in the event of an unexpected and premature shutdown of the facility, insufficient funds would have been collected and compounded to pay the decommissioning costs. To provide for this possibility, a bonding or insurance arrangement could be utilized, with the premiums reduced in proportion with the reduced potential liability as the sinking fund increases.

\subsection{OPTION III: PREPAYMENT OF COSTS}

A third alternative to funding as sioning expenses would be to require nuclear fuel cycle facilit. swn : ay the estimated costs in current dollars into some type of trur: as:c: nt at the time of facility startup. The trustees of the account would manage the monies until the funds were needed. A variety of entities could manage such a fund, as discussed previously.

Additional payments into or refunds from the trust account would be made annually as required to assure that the fund changes sufficiently to keep up with inflation and to cover changes in costs due to technological innovation and/or new regulatory requirements. 
The principal advantage of this option is the high assurance it provides that decommissioning will actually occur. This assurance is even greater than with the Annual Payment Sinking fund because sufficient money should be available even if the facility ceases operation suddenly or unexpectedly.

The Prepayment option will also require that decommissioning costs be considered when utilities are comparing the economics of coal versus nuclear power production. Under the Pay When Incurred option, the costs are so far in the future that they have little effect on the decision. (a) Under the Annual Payment Sinking Fund, the costs occur throughout the facility's lifetime and must be considered. Under the Prepayment option the costs are incurred as a lump sum at the beginning of facility life and can be considered as part of the capital cost of the facility. For a corporation using a return on investment strategy to make capital investment decisions, the initial cost required by this option will clearly make the return less attractive and may affect the decision of whether or not to build the facility.

In addition to the preceding consideration, there are several disadvantages to the Prepayment option. First, it is somewhat inequitable because future power consumers may not pay their fair share of the decommissioning costs, depending on their time of consumption. If the facility owners pay the present value of the expected decommissioning costs out of retained earnings, the future consumers will only have to pay for adjustments to the fund such as for new regulatory requirements. The facility owner is more likely to fund the cost from equity and long-term debt financing. In this case, future consumers will be ultimately charged through the pricing mechanism a sufficient amount to retire the interest and principal of the debt. The term of the debt financing will probably be less than the facility life. Thus, during the period when the debt is being retired, the consumers may pay as much or possibly even more to fund decommissioning than consumers under the Annual Payment option. When the debt is retired, consumers would pay less.

\footnotetext{
(a) The present value of $\$ 1$ payable in 30 years with a discount rate of $10 \%$ is less than $6 \notin$.
} 
A second potential disadvantange of the Prepayment option is that it will make it more difficult for the small owner to build a facility. Initial payment of decommissioning costs could increase out-of-pocket costs before startup as much as $10 \%$. For a corporation, this may alter the economics of the investment as noted above. Even for a publicly-owned utility, this additional cost before startup may cause selection of an alternative power generating system.

\subsection{COMPARISON OF TOTAL COSTS}

One factor affecting the relative desirability of the three options that has not yet been discussed is cost. Although each option ultimately provides sufficient funds for decommissioning, the funds are generated over different tim periods. Consequently, the total cost of each of the options discounted to present value is different. Meaningful comparison of the present value costs is complex because assumptions regarding the appropriate discount rate, the rate of cost escalation, and the rate of interest obtainable from invested funds must be made. Nevertheless, reasonable assumptions can be made and the costs compared.

A convincing argument can be made that, for purposes of comparing the three options, the appropriate discount rate to use is between $6 \%$ and $10 \%$, and is probably near the high end of this range. The specific rate depends on whether the facility owner is a private corporation, an investor-owned utility, or a publicly-owned utility. Definitions for the terms "interest rate," inflation rate," and discount rate," and the rationale for selecting the values used in the cost comparisons presented are contained in Appendix G.

Table 10.4-1 contains comparative present value cost information for the three options under various assumptions. Annual compounding of interest is used in all cases. All costs are based on estimated total decommissioning cost (1975 dollars) of $\$ 56$ million and a 30-year plant life. If the estimated cost in current dollars is $S$, the expected interest rate obtainable on invested funds'is $i$, the anticipated rate of inflation is $j$, and the discount rate (the rate of return that could have been realized from alternative investments) is 
$k$, then, for the Pay When Incurred option, the present value $P$ of the monies to be expended $n$ years hence will be given by:

$$
P_{I}=\frac{s(1+j)^{n}}{(1+k)^{n}}
$$

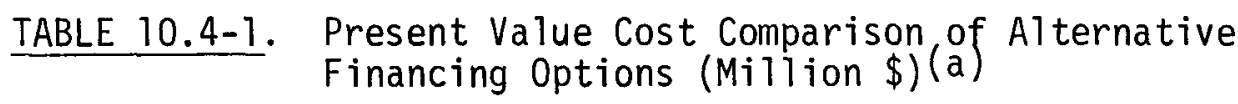

\begin{tabular}{|c|c|c|}
\hline Case & $\begin{array}{r}\text { Interest (i) } \\
\text { Inflation }(j) \\
\end{array}$ & Option \\
\hline A & $\begin{array}{l}i=4 \% \\
j=4 \%\end{array}$ & $\begin{array}{r}\text { I } \\
\text { I I } \\
\text { I I I }\end{array}$ \\
\hline B & $\begin{array}{l}i=6 \% \\
j=6 \%\end{array}$ & $\begin{array}{r}\text { I } \\
\text { I I } \\
\text { I I I }\end{array}$ \\
\hline C & $\begin{array}{l}j=8 \% \\
j=8 \%\end{array}$ & $\begin{array}{r}\text { I } \\
\text { I I } \\
\text { I I }\end{array}$ \\
\hline D. & $\begin{array}{l}i=8 \% \\
j=6 \%\end{array}$ & $\begin{array}{r}\text { I } \\
\text { I I } \\
\text { I I }\end{array}$ \\
\hline \multicolumn{3}{|c|}{ (a) $\begin{aligned} n & =30 \text { years } \\
\mathrm{S} & =\$ 56 \text { million } \\
\text { I } & =\text { Pay When Incurred } \\
\text { II } & =\text { Annual Payment Sinking Fund } \\
\text { III } & =\text { Prepayment Sinking Fund }\end{aligned}$} \\
\hline
\end{tabular}

For the Annual Payment option the present value of the sinking fund is:

$$
P_{I I}=\left\{\frac{s(1+j)^{n}}{\sum_{a=1}^{n}(1+j)^{a-1}(1+i)^{n-a}}\right\} \sum_{b=1}^{n} \frac{(1+j)^{b-1}}{(1+k)^{b}}
$$


For the Prepayment option, the present value of the initial payment, with annual adjustments to compensate for surpluses or deficits due to differences in interest and inflation rates is:

$$
P_{\text {III }}=s\left\{1+(j-i) \sum_{a=1}^{n} \frac{(1+j)^{a-1}}{(1+k)^{a}}\right\}
$$

The expressions given above for the present value of each option are derived in Appendix G.

The costs of bonding or insurance payments associated with the first and second options and the costs of administering the trust accounts for the second and third options have been neglected in computing the present values given in Table 10.4-1.

It is presently not clear just what the costs of bonding or insurance might be, since these costs are related to the amount of money at risk, the assets of the company being bonded or insured, and the probability that the bonding or insurance company would have to pay for decommissioning as a result of the financial incapacity of the owner. Also, there is virtually no experience upon which the insurance company could base its expectations of owner default. Therefore, it is assumed for this study that an annual fee equal to a percentage of the amount of money at risk would be paid to the bonding or insurance company. The amount of money at risk is the estimated decommissioning cost, adjusted for inflation, minus the funds accumulated in the sinking fund, if any. In the Pay When Incurred Case, the amount of risk increased steadily with time, assuming the inflation rate is greater then zero. In the Annual Payment Sinking Fund Case, the amount at risk increases initially and then decreases as the fund grows, reaching zero after 30 years. The effect of this additional cost item on the present value cost comparisons is shown in Table 10.4-2, for likely conditions of interest, inflation discount, and for a range of values of the insurance fee rate.

The results are very sensitive to the size of the insurance fee, as might be expected. The Pay When Incurred Plan is the least costly until the insurance fee rate exceeds about 1.7\%, when the Annual Payment Sinking Fund becomes least costly. The Prepaid Sinking Fund becomes the least costly only when the annual insurance fee exceeds about $2 \%$ of the amount at risk. 
TABLE 10.4-2. Effect of Insurance Fees on Present Value Cost Comparisons(a)

Present Value Costs (Millions \$) for Annual

Option

\begin{tabular}{|c|c|c|c|c|}
\hline $0(\mathrm{~b})$ & 0.5 & 1.0 & 1.5 & 1.9 \\
\hline 18.432 & 23.411 & 28.390 & 33.369 & 37.352 \\
\hline 24.978 & 28.064 & 31.149 & 34.235 & 36.703 \\
\hline 37.225 & 37.225 & 37.225 & 37.225 & 37.225 \\
\hline
\end{tabular}

Pay When Incurred

Annual Payment Fund

Prepayment Fund

37.225

37.225

37.225

37.225

37.225

(a) Interest $=8 \%$

Inflation $=6 \%$

Discount $=10 \%$

Dismantlement $=56$ million $\$$

(b) Values from Table 10.4-1.

Plant Life $=30$ years

\subsection{SUMMARY AND CONCLUSIONS}

Three options for financing future decommissioning costs are discussed in this section: (I) Payment of Costs as they are Incurred, (II) Creation of an Annual Payment Sinking Fund to Pay the Anticipated Costs, and (III) Prepayment of the Present Value of Anticipated Costs. Each option has advantages and disadvantages relative to each other.

Five criteria that might be used to rank the desirability of these options are:

1. The extent to which decommissioning is financially assured,

2. The present value cost of the option,

3. The extent to which the beneficiaries of the nuclear fuel cycle facility pay its decommissioning costs,

4. The extent to which the option provides for consideration of decommissioning costs when selecting among alternative power generation options, and

5. The ease of administering the option. 
These criteria clearly have different importance weights. For this study, the relative importance of the criteria is assumed to be approximately the order shown in Table 10.5-1.

Examination of Table 10.5-1 reveals that, with the weighting assumed for the criteria, the options appear to rank II, III, I in order of overall desirability. An indepth examination of all of the details involved in each option would be required before a particular financing option should be selected for implementation.

TABLE 10.5-1. Relative Desirability of Decommissioning Financing Options(a)

\begin{tabular}{|c|c|c|c|c|c|}
\hline \multirow[b]{2}{*}{$\begin{array}{l}\text { Option } \\
\text { Rating } \\
\end{array}$} & \multicolumn{5}{|c|}{ Criterion } \\
\hline & $\begin{array}{l}\text { Financial } \\
\text { Assurance of } \\
\text { Performance } \\
\end{array}$ & $\begin{array}{l}\text { Present } \\
\text { Value } \\
\text { Cost } \\
\end{array}$ & $\begin{array}{c}\text { Equity to } \\
\text { Beneficiaries } \\
\end{array}$ & $\begin{array}{c}\text { Proper } \\
\text { Consideration } \\
\text { of Costs } \\
\text { in Decision } \\
\text { Making } \\
\end{array}$ & $\begin{array}{c}\text { Ease of } \\
\text { Administration } \\
\end{array}$ \\
\hline \multirow{2}{*}{$\begin{array}{l}\text { Most } \\
\text { Desirable }\end{array}$} & III & I & II & II & I \\
\hline & II & I I & II I & I I I & I I I \\
\hline $\begin{array}{l}\text { Least } \\
\text { Desirable }\end{array}$ & I & I I I & I & I & I I \\
\hline
\end{tabular}
(a) I = Pay When Incurred
II = Annual Payment Sinking Fund III = Prepayment Sinking Fund.




\subsection{DESIGN CONSIDERATIONS TO ENHANCE DECOMMISSIONING}

In the design of nuclear facilities currently in operation in the United States, little consideration has been given to the problems of decommissioning a facility at the end of its useful life. The present study describes a set of activities and procedures that can be used to conceptually decommission a reference fuel reprocessing plant. With this study as a basis, insights have been gained as to plant design characteristics that would simplify the task of decommissioning. This section summarizes some of these potential plant design features.

It is recognized that some of the considerations intended to enhance decommissioning may not always be compatible with those plant characteristics that are desirable for normal production operations. Some of the characteristics may also be prohibitively expensive. However, the aim of this discussion is to point out design characteristics that would expedite and simplify the decommissioning task. These findings regarding desirable features for decommissioning are presented with no attempt to rank their relative importance, or to determine impacts on the rest of the plant designs, on plant production operations, or plant process performance. These, insights are aimed only at areas that present obvious complexity or difficulty to decommissioning a FRP; they are not all inclusive, and do not consider details, side effects, or variations of the alternatives. Such an analysis would require an in-depth study beyond the scope of this report.

The general criteria used in selecting design features for consideration are based on the effect they might be expected to have on decreasing decommissioning cost, improving occupational or public safety, reducing total decommissioning time, creating less radioactive waste, and the general ease of performing the decommissioning. In evaluating new design features for future decommissioning application, appropriate balance must be maintained between designs that meet these criteria and potential negative effects on plant construction and operating costs and operating characteristics. For the considerations offered, qualitative comments are made about the possible effects a given design feature might have in satisfying the selection criteria. 


\section{- Remote Maintenance}

The capability to maintain and manipulate equipment within a highly radioactive process cell without requiring entry of personnel into the cell is highly advantageous to decommissioning. This capability makes easier the functions of chemical and mechanical decontamination, it reduces costs of equipment removal, sectioning and packaging, it reduces occupational radiation exposure and reduces requirements for decontamination before other activities are undertaken. Lack of this remote handling capability, even in process cells with low to modest radiation levels, increases occupational radiation exposure in the decommissioning of an FRP.

\section{- Compartmentation of Process Functions}

Compartmentation of process functions with comparable unit operations and with comparable radioactivity levels in each compartment (i.e., process cell) is desirable for decommissioning. With this design feature, high radioactive contamination levels in one set of process equipment does not affect significantly the decommissioning of equipment with lower contamination levels. Application of this feature is expected to ease decommissioning efforts, reduce occupational radiation exposure, and reduce costs. A potential disadvantage of compartmentation is that more surface areas are present (from more wa11s), and more piping is required.

\section{- Process Cell Liners}

Conventional stainless steel cell liners (i.e., thin liners anchored in many places to the concrete) appear to have a net benefit to decommissioning. Stainless steel can be decontaminated relatively effectively, thus reducing the decontamination efforts required to allow personnel entry into a process cell to complete the decommissioning. On the other hand, the many anchors securing the liner to the concrete make the job of removing the liner quite difficult. Liners that are sufficiently rigid to be free standing and are connected to the concrete only at the interface seals between the liner and the concrete would appear to offer more advantages to decommissioning than the 
conventionally-anchored liners. In addition, covering more wall area with stainless steel liners in the process cells (depending on process equipment location and function) should ease decommissioning. Less radioactive concrete rubble as waste may also result from using this concept. These comments generally apply also to liners in fuel and waste canister storage pools.

- Protective Coatings

Protective coatings on cell concrete can reduce the amount of radioactive contamination absorbed in the concrete and assist in obtaining good chemical clean-up of the cell concrete. However, to be fully effective, these protective coatings should maintain high integrity over the life of the plant, and should resist deterioration caused by radiation and by process and decontamination chemicals. It is believed that the presently utilized coatings can not achieve the desired degree of assurance. Thus, it appears desirable to develop materials and application methods that would provide the assurance of higher performance. Recoating the exposed concrete surfaces periodically during the life of the plant may accomplish the same objective. Employment of this feature is expected to ease decommissioning efforts, reduce occupational radiation exposure, and reduce costs.

- High-Level Liquid Waste Storage

Decommissioning of high-level and intermediate-level liquid waste storage tanks was found to be one of the most difficult tasks in this study. Consequently, it is clearly undesirable from the standpoint of decommissioning to have interim storage of these liquid wastes. This storage could be eliminated by solidifying the wastes as they are generated in the mainline process.

Alternatively, if such waste storage is incorporated into the plant design, it would be preferable to incorporate the following features:

- Locate the waste storage tanks such that ready access is provided to the total area above the tanks. This access could be obtained by locating the tanks below a canyon-type structure. Having no structure at all above the 
tanks would be preferred to the design concept in the reference plant studied in this report wherein service areas (i.e., the Waste Tank Equipment Gallery) are located above the tanks.

- Include capability for inserting nozzles for chemical decontamination sprays into many locations within the tanks.

- Provide built-in capability to remove all liquid in the tanks except for liquid films clinging to surfaces.

- Provide a system for waste heat removal that eliminates or reduces the amount of piping inside the tanks. An example of a method for doing this is to allow the tanks to boil and remove the heat from the vapors in external heat exchangers, with return of the condensate to the tanks. The heat exchangers would be exposed to solutions with radioactivity levels 0.001 to 0.0001 times those in the waste tanks, thus would be easier to decontaminate.

- Locate the waste solidification process equipment in the main process building in remotely operated cells. This design feature provides for more effective use of existing service facilities. Complementary to this feature would be the elimination of some of the waste solidification off-gas treatment equipment by routing the off gases to comparable capabilities that exist in the main process building. This feature would reduce the amount of process equipment and process cell space that needs decommissioning.

- Decrease the amount of irregular surface areas on the outside of the tanks (e.g., eliminate stiffener ribs on the sides and top, and the numerous support ribs under the tank bottom in the reference plant). Using this feature should render chemical decontamination more effective.

- Access to Process Equipment

Ready access to all contaminated process equipment is highly desirable. One technique for accomplishing this feature is to have a canyon-type facility 
above all process cells with removable cell ceilings that are above most of the equipment. Access could perhaps also be provided from the side walls of the process cells. This access could have some combination of large openings and ports through which decontamination equipment or chemicals could be passed.

A parallel feature is to have remotely-operated crane access to the process equipment. This feature would reduce occupational exposure by reducing the need for personnel entry into the cell, and would minimize the need to use special equipment or innovative techniques to decommission the process cells.

Good access to process equipment is expected to provide improvements in all the areas presented in the criteria listed earlier in this section.

\section{- Built-in Provisions for Chemical Decontamination}

The reference facility has a number of built-in provisions for chemical decontamination within process cells. However, additional capability in some areas (e.g., the high-level cell and similar process cells) is desirable. This capability would allow for more effective chemical decontamination, thus less occupational radiation exposure, lower costs, and possibly less decommissioning wastes. Examples of desirable features from the standpoint of decommissioning are to provide the capability to completely fill all vessels and their components, and piping with decontaminating chemicals; and to pretreat the equipment surface areas (such as by electropolishing) before operation to permit easier decontamination.

\section{- Capability to Process Low-Level Wastes}

Capability beyond that in the reference plant for treating, handling, and packaging low-level wastes would be desirable. Such capability need not necessarily be installed during production operations, but provisions for its installation during decommissioning would be highly desirable. Examples of this capability are: volume reduction of combustible waste (e.g., incineration, digestion, compaction), sectioning or compaction of removed noncombustible materials, and electropolishing for decontamination of contaminated metallic equipment. Use of this capability should decrease waste management costs significantly. 
- Isolation of Sections of the Ventilation System

During decommissioning, isolation of sections of the process area ventilation systems is required to provide for better confinement of radioactivity during selected decommissioning activities. Decommissioning could be expedited by providing built-in capability for ventilation system changes, especially in areas where the ventilation equipment is not readily accessible.

- Process Equipment Sizing

The plutonium nitrate storage tanks in the reference reprocessing plant are large slab-shaped tanks. These tanks are larger than the currently planned access portal at the geologic repository for transuranic-containing waste. Thus, the tanks in the reference plant (and their neutron shields) require a considerable amount of sectioning to meet disposal packaging requirements. A modified tank design, such as small cylinders or moderately-sized annular cylinders, would allow for packaging without sectioning. This would reduce occupational exposure, reduce the potential for unplanned plutonium releases during decommissioning, and accelerate the removal of the plutonium nitrate tanks. (a)

Other places where attention to equipment sizing could be beneficially employed are heat exchangers, tube bundles, waste calciners and vitrifiers, and other process vessels.

- Stainless Steel Liners in Pipe Trenches

Stainless steel liners in pipe trenches, particularly those trenches small enough to make human access difficult, are difficult and cumbersome to chemically and mechanically decontaminate. An example of an alternative approach would be leave the trench unlined and place each pipe or a group of pipes inside another larger pipe for double containment. This feature, in combination with built-in capability to section and "pull out" the pipes

(a) Alternatively, decommissioning could be aided by increasing the access portal size at the geologic disposal site. 
from one or both ends of the trench, would expedite decommissioning of these areas, reduce costs, and reduce occupational exposure.

\section{- Built-in Capability for Mechanical Decontamination}

Removal of contaminated concrete in process areas is one of the more laborious and time-consuming activities in decommissioning a FRP. The methods used in this study require drilling and use of explosives and rock splitters. These methods could be carried out much more quickly and with less cost if holes were built into the concrete surfaces (but sealed from process materials) for placement of explosives, etc., for removal of concrete surfaces. Built-in provisions for other techniques, such as spalling of the concrete by heat or electric current, might also be employed.

\section{- Colocation of Fuel Cycle Facilities}

Colocation of a fuel reprocessing plant with other nuclear fuel cycle facilities would offer some advantages to decommissioning. First, decommissioning costs would be reduced somewhat because of the shared costs for services and utilities; secondly, decommissioning costs and time would be reduced because of the greater flexibility and availability of onsite staff (which would also tend to reduce the need for "incentive pay" to keep a decommissioning staff intact until the work was completed); and thirdly, costs would be reduced for surveillance and maintenance during the interim care period following layaway or protective storage activities, because of sharing of utilities and services. 



\section{$1,2.0$ GLOSSARY}

Abbreviations, terms, definitions, and symbols directly related to decommissioning work and related technology are defined and explained in this section. It is divided into two parts with the first part containing the abbreviations and Greek letters, and the second part containing terms, and definitions (including those used in a special sense for this work.) Common terms covered adequately in standard dictionaries are not included.

\subsection{GLOSSARY-ABBREVIATIONS}

ABS Analytical Blower Station

AFS Analytical Filter Station

AGNS A7lied General Nuclear Services

ALARA As Low As Reasonably Achievable $\mathrm{e}^{(a)}$

AMG Aqueous Makeup Gallery

APS Atmospheric Protection System

ATMX Army Transport Mobile For Explosives(a)

AVOS Analytical Viewing and Operating Station

BNFP Barnwell Nuclear Fuel Plant

BS Blower Station

BWR Boiling Water Reactor

CCS Cold Chemical Station

CDC Canister Decontamination Cubicle

CEMG Crane and Equipment Maintenance Gallery

CERS Contact Equipment Removal Station

CFR Code of Federal Regulations (a)

Ci Curie ${ }^{(a)}$

CLRA Change and Lunch Room Area

CLS Cask Loading Station

$C P$ Cooling Pond (Beacon Pond)

CRA Control Room Area

CSA Chemical Storage Area

(a) See Section 12.2 for additional information or explanation. 


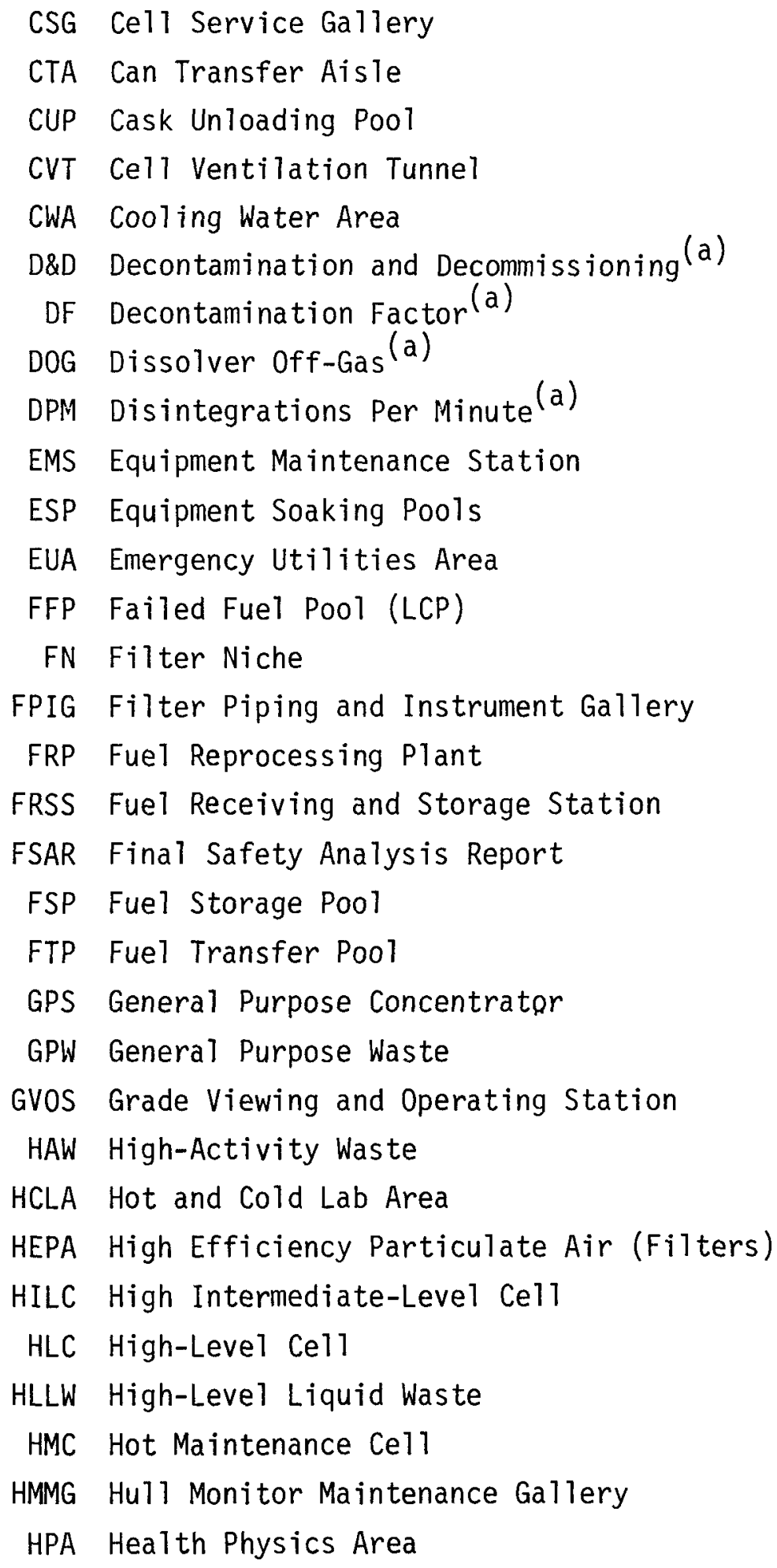

(a) See Section 12.2 for additional information or explanation. 
HPLA Health Physics Laboratory Area

HPS Health Physics Section

HPT Hot Pipe Trench

HTG Head Tank Gallery

HVAC Heat Ventilation and Air Conditioning

ILC Intermediate Level Cel1

ILLW Intermediate Level Liquid Waste

LA Lab Aisles

LAA Lower Access Aisles

LAW Low Activity Waste

LCP Leaker Can Pool (FFP)

LEMUF Limits of Error Material Unaccounted For

LPIG Lower Piping and Instrument Gallery

LVOS Lower Viewing and Operating Station

LWR Light Water Reactor

mrad Millirad (a)

mr Milliroentgen $(a)$

MRS Manipulator Repair Station

MS Maintenance "hop

MT Metric Tor. (.)

MTHM Metric Ton Heavy Meta ${ }^{(a)}$

MUF Material Unaccounted For

MW/MTU Thermal Megawatts Per Metric Ton of Uranium

MWd/MTU Thermal Megawatt-day Per Metric Ton of Uranium, the Burnupla)

MOX Mixed Oxide

NFS Nuclear Fuel Services

NRC Nuclear Regulatory Commission

OG Operating Gallery

OGTC Off Gas Treatment Cell

PEG Pulser Equipment Gallery

PNC Plutonium Nitrate Storage Cells

PNCA Plutonium Nitrate Control Area

${ }^{(a)}$ See Section 12.2 for additional information or explanation. 
PNOS Plutonium Nitrate Operating Station

PNSL Plutonium Nitrate Storage Load-out

PPC Plutonium Product Cell

$\mathrm{PuO}_{2}$ Plutonium Dioxide

PWR Pressurized Water Reactor

Q.A. Quality Assurance (a)

Q.C. Quality Control (a)

$R$ Roentgen (a)

rad Radiation Absorbed Dose ${ }^{(a)}$

rem Roentgen Equivalent Man (a)

RMSC Remote Maintenance and Scrap Ce11

RPC Remote Process Ce11

SAC Sample and Analytical Cells

SCG Service Concentrator Gallery

SC/ICM Spray Calciner/In-Can fielter

SNM Special Nuclear Materizi "

SS Stainless Steel

TAA Top Access Aisle

TBP Tributyl Phosphate

TPIG Top Piping and Instrument Gallery

TRU Transuranic (a)

TVOS Top Viewing and Operating Station

$T_{1 / 2}, T_{R}$ Half Life, Radiological $(a)$

UA Utility Area

UPC Uranium Product Cell

VFS Ventilation Filter Station

VOG Vessel off Gas

VSA Ventilation Supply Area

WOG Waste Off Gas

WSG Warm Service Gallery

WSP Waste Solidification Plant

(a) See Section 12.2 for additional information or explanation. 

WTC Waste Tank Cells
WTDC Waste Tank Diverter Cell
WTEG Waste Tank Equipment Gallery
WTOG Waste Tank Off Gas
WTPV Waste Tank Pipe Vault
WTSC Waste Tank Sample Cell
WVC Waste Vitrification Cel1

\title{
Greek Letters:
}

\author{
$\alpha$ Alpha Radiation(a) \\ B Beta Radiation (a) \\ $\gamma$ Gamma Radiation(a) \\ $x$ Chi, Concentration, $\mathrm{Ci} / \mathrm{m}^{3}$ \\ Q Released Quantity of Radioactive Material, Ci/sec \\ Q' Release Rate of Radioactive Material, Ci/sec \\ $\bar{x} / Q^{\prime}$ Chi-bar/Q prime, normalized average air concentration $\left(\mathrm{Ci} / \mathrm{m}^{3}\right.$ \\ per $\mathrm{Ci} / \mathrm{sec}$ released, also written $\mathrm{sec} / \mathrm{m}^{3}$ ). Also called the \\ annual average atmospheric dilution factor.
}

\subsection{GLOSSARY-DEFINITIONS}

Abnormal Environmental Occurrence:

An event that 1) results in noncompliance with, or is in violation of, an Environmental Technical Specification, or 2) results in uncontrolled or unplanned releases of chemical, radioactive, or other discharges from the plant in excess of Federal, State, or local regulations.

Absorbed Dose:

When ionizing radiation passes through matter, some of its energy is imparted to the matter. The amount absorbed per unit mass of irradiated material is called the absorbed dose: it is measured in rems and rads.

(a) See Section 12.2 for additional information or explanation. 
Actinides:

Activity:

Airborne Radioactive Material:

Air Lift:

Air Lift Circulator:

ALARA:

Alpha Decay:

Alpha Particle:

Alpha Emitter:
A series of heavy radioactive metallic elements of increasing atomic number ( $Z$ ) beginning with actinium (89) or thorium (90) and ending with element hehnium of a tomic number 105.

Sometimes used for the term "radioactivity"

Radioactive particulates, mists, fumes, and/ or gases, air.

A device used for transferring liquid from one place to another by metering air into the lower end of a liquid column. The airliquid mixture is lighter than liquid alone, and travels upward in the column, above the liquid level.

A device for raising (circulating) liquid by introducing compressed air into the liquid near the bottom of a pipe. The air-liquid mixture, being lighter than liquid alone, rises in the submerged pipe, causing flow of liquid.

A philosophy to maintain exposures to radiation As Low As is Reasonably Achievable.

Radioactive decay in which an alpha particle is emitted. This transformation lowers the atomic number of the nucleus by two and its mass number by four.

A positively charged particle emitted by certain radioactive materials. It is made up of two neutrons and two protons, hence is identical with the nucleus of a helium atom. It is the least penetrating of the three common types of radiation (alpha, beta, gamma) emitted by radioactive material.

A radionuclide that undergoes transformation by emission of alpha particles. 
ATMX:

Atomic Number $(Z)$ :

Background:

Ballast Tank Circulators:

Beta Decay:

Beta Particle:

Burial Grounds:
Railcars that are effectively used in transporting large quantities of low-level waste; specially reinforced, they have interior dimensions of $2.74 \mathrm{~m}(9 \mathrm{ft}) \times 2.74 \mathrm{~m}(9 \mathrm{ft})$ $x 15.24 \mathrm{~m}(50 \mathrm{ft})$ with a useful load of $45,813 \mathrm{~kg}(101,000 \mathrm{1b})$. The Army Transport Mobile Explosives units were originally used by the U.S. Army for the transport of conventional explosives. The cars used for transporting nuclear materials are modified versions of the standard car.

The number of protons in the nucleus of an atom; also its positive charge. Each chemical element has its characteristic a tomic number, and the a tomic numbers of the known elements form a complete series from 1 (hydrogen) to 105 (hehnium).

That level of radioactivity from external sources existing without the presence of a nuclear plant, adjusted for any change occurring during the lifetime of a nuclear facility such as might result from atmospheric weapons testing.

A device to circulate liquids by periodic pulsing of air through a chamber. The submerged pressure chamber has a compressed air supply, a bleed-off orifice at the top, and a bottom discharge leg. Pulsed air drives liquid out the bottom with sufficient velocity to scour the area below it and resuspend particulate matter. The orifice allows the chamber to vent the air and to refill with liquid from the next pulse of air.

Radioactive decay in which a beta particle is emitted or in which an orbital electron capture occurs.

An electron, of either positive or negative charge, which has been emitted by an atomic nucleus in a nuclear transformation.

Areas designated for storage of containers of packaged radioactive wastes in nearsurface soils. 
Burnup, Specific:

Calcine:

Cask:

Chemical Limits:

Chemical Reprocessing:

Code of Federal Regulations (CFR):

Contact Maintenance:
The total energy released per unit mass of a nuclear fuel. It is commonly expressed in megawatt-days per ton. (Also called fuel irradiation level.)

To heat a substance to a high temperature, but below its melting point, causing loss of volatile constituents such as moisture. Also a noun.

A heavily shielded shipping container for radioactive materials. Some casks weigh as much as 100 tons.

Maximum concentrations or quantities imposed upon chemical releases in gaseous or liquid effluents discharged from a facility, and consistent with known air or water quality standards.

Operations involved in the recovery of fissile material from irradiated fuel assemblies by chemical treatment. Chemical processing usually is done by dissolving the fuel in liquids and performing separation of products ( $U$ and $\mathrm{Pu}$ ) from wastes by chemical differences in the liquid phase. Chemical reprocessing includes such operations as dissolving fuel, solvent extraction, heating or transferring process solutions, and adjusting chemical composition of process solutions.

The Code of Federal Regulations is a codification of the general rules by the Executive departments and agencies of the Federal Government. The Code is divided into 50 titles that represent broad areas subject to Federal regulation. Each title is divided into Chapters that usually bear the name of the issuing agency. Each Chapter is further subdivided into Parts covering specific regulatory areas.

"Hands-on", or maintenance performed by direct contact of personnel with the equipment. Most nonradioactive maintenance is contact maintenance. 
Contamination:

Critical:

Critical Mass:

Curie:

Decay, Radioactive:

Decommissioning:

Decontamination:
Radioactive material or materials that have been deposited on the surfaces of structures or equipment or that have been mixed with another material.

A condition wherein a medium is capable of sustaining a nuclear chain reaction. The system has an effective multiplication factor equal to or greater than unity.

Prompt critical is being capable of sustaining a chain reaction without the aid of delayed neutrons.

The mass of fissionable material that will support a self-sustaining chain reaction under stated conditions.

The special unit of activity. One curie equals $3.7 \times 1010$ nuclear transformations per second. (Abbreviated $\mathrm{C} i$ ). Several fractions of the curie are in common usage:

- Millicurie. One-thousandth of a curie Abbreviated $\mathrm{mCi}$.

- Microcurie. One-millionth of a curie Abbreviated $\mu \mathrm{Ci}$.

- Nanocurie. One-billionth of a curie Abbreviated $\mathrm{nCi}$.

- Picocurie. One-millionth of a microcurie Abbreviated $\mathrm{pC} i$; replaces the term $\mu \mu \mathrm{c}$.

A spontaneous nuclear transformation in which a particle, gamma radiation, or $x$ radiation are emitted following orbital electron capture or spontaneous fission of the nucleus.

The execution of a program to reduce the radioactivity levels in a nuclear facility to reduce the potential health and safety impact on the public.

Those activities employed to reduce the levels of contamination in or on structures and equipment. 
Decontamination Agents:

Decontamination Factor (DF):

De minimus Level:

Design Basis Accident:

Discount Rate:

Disintegration, Nuclear:

Disintegration Rate:

Dispersion:

Disposal:

Dissolver Off-Gas System (DOG): The vapor treatment system for the fuel

dissolvers in a fuel reprocessing plant.

Those chemical materials used to effect decontamination.

The ratio of the initial concentration of an undesired material to the final concentration resulting from a treatment pro. cess. The term may also be used as a ratio of quantities.

That level of contamination acceptable for unrestricted public use or access.

A postulated accident believed to have the most severe expected impacts on a facility. It is used as the basis for safety and structural design.

The rate of return on capital that could have been realized in alternative investments, if the money were not committed to the plan being evaluated, i.e., the opportunity cost of alternative investments. This cost is equivalent to the weighted average cost of capital. (1)

Spontaneous nuclear transformation (radioactivity) characterized by the emission of energy and/or mass from the nucleus. The process is characterized by a definite half-life.

The rate at which disintegrations occur, characterized in units of time; i.e. disintegrations per minute $(\mathrm{dpm})$, etc.

A process of mixing one material within a larger quantity of another. For example, the mixing of material released to the atmosphere with air causes a reduction in concentration with distance from the source.

The disposition of materials with the intent that the materials will not enter man's environment in sufficient amounts to cause a health hazard. 
Dose, Absorbed:

Dose, Equivalent:

Dose, Occupational:

Dose, Radiation:

Dose Rate:

Dosimeter:

Enrichment:

Exposure:

Facility:
The mean energy imparted to matter by ionizing radiation per unit mass of irradiated material at the place of interest. The unit of absorbed dose is the rad. One rad equals 0.01 Joules/kilogram in any medium (100 ergs per gram.)

Expresses the amount of effective radiation, in man, expressed in rems, when modifying factors have been considered. The product of absorbed dose multiplied by a a quality factor multiplied by a distribution factor.

The exposure of an individual to radiation above background as imposed by his employment.

As commonly used, it is the quantity of radiation absorbed in a unit mass of a medium, frequently a human organ.

The radiation dose delivered per unit time and measured, for instance, in rems per hour.

A device, such as a film badge or ionization chamber, that measures radiation dose.

The ratio (usually expressed as a percentage) of fissile isotope to the total amount of the element (e.g., the $\%$ of $235 \mathrm{U}$ in uranium.)

A measure of the ionization produced in air by $x$ or gamma radiation. It is the sum of the electrical charges on all ions of one sign produced in air when all electrons liberated by photons in a volume element of air are completely stopped in air, divided by the mass of the air in the volume element. The special unit of exposure is the roentgen. (See Roentgen.)

The physical complex of buildings and equipment within a site. 
Fission:

Fission Products:

Food Chain:

Fuel Assembly:

Fuel Cycle:

Fue1 Element:

Fuel Pool Cooling System:

Fuel Reprocessing:

Fuel Storage Pool:
The splitting of a heavy nucleus into two lighter parts (nuclides of lighter elements), accompanied by the release of a relatively large amount of energy and generally one or more neutrons. Fission can occur spontaneously, but usually it is caused by nuclear absorption of gamma rays, neutrons, or other particles.

The lighter nuclides (fission fragments) formed by the fission of heavy elements. It also refers to the nuclides formed by the fission fragments' radioactive decay.

The pathways by which any material (such as radioactive material from fallout) passes through man's environment through edible plants and/or animals to man.

A grouping of fuel elements that supply the nuclear heat in a nuclear reactor. A fuel element is the smallest structurally discrete part of a reactor or fuel assembly that has nuclear fuel as its principal constituent.

The series of steps involved in supplying fuel for nuclear power reactors.

Head end: Mining, milling, enrichment, and fabrication of fuel.

Back end: Includes reactors, spent fue] storage, spent fuel reprocessing, mixed-oxide fuel fabrication and waste management.

A rod, tube, plate, or other form into which nuclear fuel is fabricated for use in a reactor.

The system that cools and purifies the water in the fuel storage pool.

Same as chemical reprocessing.

A large concrete box full of water that provides storage and servicing facilities for nuclear fuel elements. 
Gamma Rays:

Gaseous:

Greenhouse:

Guard:

Half-Life Biological:

Half-Life Effective:

Ha]f-Life Radioactive:
High-energy, short-wavelength, electromagnetic radiation. Gamma radiation frequently accompanies alpha and beta emissions and always accompanies fission. Gamma rays are very penetrating and are best stopped or shielded against by dense materials such as lead or depleted uranium. The rays are similar to $x$-rays, but are usually more energetic, and are nuclear in origin; i.e. they originate from within the nucleus of the atom.

Material in the vapor or gaseous state, but can include entrained liquids and solids. A gas will completely fill its container regardless of container shape or size.

A temporary structure, frequently constructed of wood and plastic, used to provide a confinement barrier between a radioactive work area and the environs.

An individual whose primary duty is the guarding and protection of material against theft and/or the protection of the facility against industrial sabotage.

The time required for a biological system, such as a man or animal, to eliminate, by natural processes, half the amount of a substance (such as a radioactive material) that has entered it.

The time required for a radionuclide containes in a biological system, such as a man or animal, to reduce its radioactivity by half as a combined result of radioactive decay and biological elimination.

The time in which half the atoms of a particular radioactive substance disintegrates to another nuclear form. Each radionuclide has a unique half-life.

Measured half-lives vary from millionths of a second to billions of years. 
Health Physicist:

Health Physics:

Heel:

High-Level Radioactive Waste:

Hot Spots:

Immobilization:

Interim Care Period:

Interim Storage:

Intrusion Alarm:
A person trained to perform radiation surveys, oversee radiation monitoring, estimate the degree of radiation hazard, and advise on radiation hazards.

The science concerned with recognition, evaluation, and control of health hazards from ionizing radiation.

The material (e.g., liquid waste) left in a vessel from the previous emptying. Special means must usually be provided to minimize the heel in a vessel.

It is radioactive waste separated from the nuclear fuel reprocessing from the firstcycle solvent extraction system, or equivalent, and other concentrated wastes, or equivalent. It also applies generally to highly radioactive wastes of other origins.

Areas of radioactive contamination of a concentration higher than the average.

Treatment and/or emplacement of materials (e.g., radioactive contamination) so as to impede its movement.

A period of time starting after the decommissioning activities cease and wherein periodic surveillance and maintenance takes place. The duration of time can vary from a few years to more than 100 years; also called the continuing care period.

Storage operations for which a) monitoring and human control are provided and b) subsequent action in which final disposition is expected.

Concepts for interim storage include bulk or compartmented storage of solid, liquid, and gaseous wastes.

A secure electrical, electro-mechanical, electro-optical, electronic, mechanical or similar device capable of detecting intrusion by individuals into a protected area by means of visible or audible alarmed signal. 
Ion Exchange:

Jetting:

Licensed Material:

Liquid Radioactive Waste:

Long-Lived Nuclides:

Low-Level Waste:

Management (Waste):

Man-rem:

Mass Numbers:
A chemical process involving the absorption or desorption of various chemical ions in a solution onto a solid material, usually a plastic or resin. The process is used to separate and purify chemicals, such as fission products or hardness in water (i.e., water softening).

A technique for pumping a liquid or a gas by use of high pressure air, steam or water through especially designed nozzles. "Jet" is short for ejector.

Source material, special nuclear material, or by-product material received, possessed, used, or transferred under a license issued by the Nuclear Regulatory Commission.

Solutions, suspensions, and mobile sludges, contaminated with radioactive materials.

For this study, radioactive isotopes with long half-lives typically taken to be greater than about 10 years. Most nuclides of interest to waste management have halflives on the order of one year to millions of years.

Wastes containing types and concentrations of radioactivity such that no shielding or relatively little shielding to minimize personnel exposure is required.

The planning, execution, and surveillance of essential functions related to radioactive waste, including treatment, solidification, interim or long-term storage, transportation and disposal.

Used as a measure of population dose and it is calculated by summing the dose equivalent in rem received by each person in the population. Also, it is used as the absorbed dose of one rem by one person with no rate of exposure inferred.

The number of nucleons (protons and neutrons) in the nucleus of an atom. (Symbol: A). 
Maximum Individual:

Megawatt-day per metric ton:

Millirad:

Milliroentgen:

Monitoring:

MOX:

MT:

MTHM:

MW/MTU:

MWd/MTU:

Normal Operating Conditions:

Nuclear Reaction:

Offsite:

Onsite:

Operable:
A hypothetical individual in the general population who is located at the highest ground level and is subject to the greatest concentration of the material that is discharged from the plant.

A unit for expressing the burnup of fuel in a reactor; specifically, the number of megawatt-days of heat output per metric ton of fuel in the reactor.

A unit of absorbed dose (one thousandth of a rad.) (See absorbed dose.)

A submultiple of the roentgen, equal to one-thousandth of a roentgen. (See Roentgen.)

Taking measurements or observations for recognizing adequacy, significant changes in, conditions or performance of a facility or area.

An acronym for mixed oxide. A mixture of uranium and plutonium dioxide.

Metric Ton. See Tonne.

Metric ton of heavy metal $(U+P u)$. (See also specific power.)

Thermal megawatts per metric ton of uranium.

Thermal megawatt-days per metric ton of uranium; also called burnup. (See also specific power.)

Operation (including startup, shutdown, and maintenance) of systems within the normal range of applicable parameters.

A reaction involving a change in an atomic nucleus, such as fission, fusion, or particle capture, or radioactive decay.

Beyond the boundary line marking the limits of plant property.

Within the boundary line marking the limits of plant property.

Capable of performing the required function. 
Overpack:

Package:

Packaging:

Possession-0nly License:

Present Value of Money:

Primary Wastes:

Process Cêlls:

Process Equipment:

Protective Clothing:
Secondary (or additional) external containment for packaged nuclear waste.

The packaging plus the contents of radioactive materials.

The assembly of radioactive material in a container and other components necessary to assure compliance with prescribed regulations.

A license issued to a nuclear facility owner by the NRC entitling the licensee to own a nuclear facility but not operate jt.

When different business activities require disbursement of funds over different time frames, it is difficult to compare the actual cost of each activity to the sponsoring organization. One generally accepted method of placing these various disbursements on a common bas is is to compute the value of those disbursements in terms of current dollars, i.e., the present value of money to be paid out or received at some time other than the present. For an investor, "the present value of a future payment or series of payments is the present investment necessary to secure the promise of that future payment or series of payments, with interest at a given rate." $(2)$

Wastes that are generated as part of a primary operation. Secondary wastes are generated from a supporting operation, such as waste treatment.

Heavily shielded rooms housing radioactive systems.

The functional equipment items or systems associated directly with the operation of a chemical or mechanical operation.

Special clothing worn by a person in a radioactively contaminated area to prevent contamination of his body or personal clothing. 
Protective Survey:

Q-Designated Items:

Quality Assurance:

Quality Control:

Rad:

Radiation:
An evaluation of the radiation and its hazards incidental to the production, use or existence of radioactive materials. It normally includes a physical survey of the arrangement and use of equipment and measurements of the radiation dose rates under expected conditions of use. Also called protection survey.

The safety-related characteristics of those structures, systems, and components, both active and passive, that prevent or mitigate the consequence of postulated accidents that could cause undue risk to the health and safety of the public. Items defined as "Q" require the implementation of Quality Assurance Programs as set forth in Appendix B of 10 CFR Part 50. (See Safety Related also.) These items will withstand Design Basis Earthquakes or Design Basis Tornadoes.

The systematic actions necessary to provide adequate confidence that a material, component, system, process, or facility performs satisfactorily or as planned in service.

The quality assurance actions that control the attributes of the material, process, component, system, or facility in accordance with predetermined quality requirements.

The unit of absorbed dose. The energy imparted to matter by ionizing radiation per unit mass of irradiated material at the place of interest. One rad equals 0.01 Joules/kilogram of absorbing material.

(1) The emission and propagation of radiant energy: for instance, the emission and propagation of electromagnetic waves, or of sound and elastic waves. (2) The energy propagated through space or through a material medium; for example, energy in the form of alpha, beta, and gamma emissions from radioactive nuclei. 
Radiation Area:

Radiation Background:

Radiation Leakage (Direct):

Radiation Scattered:

Radiation Stray:

Radioactive Material:

Radioactivity:

Radioactivity Artificial:

Radioactivity Induced:

Radioactivity Natural:
Any area, accessible to personnel, in which there exists radiation at such levels that a major portion of the body could receive in any one hour a dose in excess of 2 millirem, or in any 7 consecutive days a dose in excess of 100 millirems.

See Background.

Al1 radiation coming from a source housing except the useful beam.

Radiation that has been deviated in direction during its passage through a sub-

stance. It may also have been modified by a decrease in energy.

The sum of leakage and scattered radiation; also called "shine".

Any material or combination of materials which spontaneously emits ionizing radiation and which has a specific activity in excess of 0.002 microcuries per gram of material. (49 CFR 173.389(e)).

The property of certain nuclides of spontaneously emitting particles or gamma radiation or of emitting $x$ radiation. Often shortened to "activity".

Manmade radioactivity produced by particle bombardment or electromagnetic irradiation, as opposed to natural radioactivity.

Radioactivity produced in a substance after bombardment with neutrons or other particles. The resulting radioactivity is "natural radioactivity" if formed by nuclear reactions occurring in nature, and "artificial radioactivity" if the reactions are caused by man.

The property of radioactivity exhibited by more than fifty naturally occurring radionuclides. 
Radioactive Series:

Radiological Protection:

Red 0i1:

Regulatory Guides:

Rem:

Remote Maintenance:
A succession of nuclides, each of which transforms by radioactive disintegration into the next until a stable nonradioactive nuclide results.

The first member is called the "parent", the intermediate members are called "daughters", and the final stable member is called the "end product."

Protection against the effects of internal and external human exposure to radiation and to radioactive materials.

A term used to designate an explosive nitrated organic liquid. A potentially dangerous phase which may form if organic materials such as tributyl phosphate (TBP) are heated in the presence of heavy metals in solution. Red oil is highly temperature sensitive. A rapid reaction cannot be initiated at temperatures below $135^{\circ} \mathrm{C}$.

Regulatory Guides are issued to describe and make available to the public, methods acceptable to the NRC staff for implementing specific parts of the NRC's regulations, to delineate techniques used by the staff in evaluating specific problems or postulated accidents, or to provide other guidance to applicants for nuclear operations. Guides are not substitutes for regulations and compliance with them is not explicitly required. Methods and solutions different from those set out in the guides are acceptable if they provide a basis for the findings requisite to the issuance or continuance of a permit or license by the NRC.

(Acronym for Roentgen Equivalent Man). A unit of dose equivalent. The dose equivalent in rems is numerically equal to the absorbed dose in rads multiplied by the quality factor, the distribution factor, and any other necessary modifying factors.

Maintenance by remote means; i.e., the human is separated from the item being maintained by a shielding wall. 
Repository (Federal):

Restricted Area:

Roentgen:

Safety-Related:

Scarfing:

Secondary Wastes:

Security Officer:

Shield:
A site owned and operated by the Federal Government for long-term storage or disposal of radioactive materials.

Any area to which access is controlled for protection of individuals from exposure to radiation and radioactive materials.

A unit of exposure to ionizing radiation. It is that amount of gamma or $X$ rays required to produce ions carrying one electrostatic unit of electrical charge (either positive or negative) in one cubic centimeter of dry air under standard conditions. One roentgen equals $2.58 \times$ $10^{-4}$ coulomb per kilogram of air. (See also Exposure.)

Structures, systems, and components, whose functions tend to prevent or mitigate the exceeding of safety limits, as defined in Regulatory Guide 3.6, and set forth in Technical Specifications which are part of the Operating License for a nuclear power plant. Quality Assurance Programs as defined in Appendix B of 10 CFR Part 50 are not required for safety-related items except those defined also as "Q".

A removal technique used to mechanically decontaminate concrete by chipping, cutting, jackhammering, or blasting the surface 1ayer(s) away.

Forms and quantities of a 11 wastes that result from treatment of primary wastes or effluents.

A guard or watchman whose primary duty is the protection of material and property.

A body of material used to reduce the passage of particles or radiation. A shield may be designated according to what it is intended to absorb (as a gamma ray shield or neutron shield), or according to the kind of protection it is intended to give (as a background, biological, or thermal shield). 
Short-Lived Radionuclides:

Shutdown:

Site:

Solid Radioactive Waste:

Solidification:

Sparging:

Special Nuclear Material:

Specific Power (of Fue] Assemblies):

Surface Contamination:
It may be required for the safety of personnel or to reduce radiation enough to allow use of counting instruments for research or for locating contamination or airborne radioactivity.

For this study, those radioactive isotopes with half-lives less than about 10 years.

The time during which a site is not in production operation.

The geographic area upon which the facility is located and which is subject to controlled public access by the facility licensee (includes the restricted area as designated in the NRC liscense).

Material that is essentially solid and dry but may contain sorbed radioactive fluids in sufficiently small amounts as to be immobile.

Conversion of radioactive wastes (gases or liquids) to dry, stable solids.

To stir a liquid by introduction of a gas near the bottom of the containing vessel.

Plutonium, uranium enriched in the isotope, 233 or 235 , and any other material as defined in 10CFR51 by the NRC.

Commonly expressed in units of thermal megawatts per metric ton of uranium (MW/MTU). It represents the rate at which thermal energy is extracted from the fuel; burnup, commonly expressed in thermal megawattdays per metric ton of uranium (MWd/MTU), represents the total integrated energy extracted. For MOX fuel, the unit of fuel is a metric ton of heavy metal (MTHM); i.e., a metric ton of $(U+P u)$.

The deposition and attachment of radioactive materials to a surface. 
Survei11ance:

Survey:

Tonne:

Track Dri11:

Transuranic Elements:

Transuranic Waste:

Underground Solid Waste Storage Area:

Waste, Radioactive:

$X$ Ray:
Those activities necessary to assure that the site remains in a safe condition (including periodic inspection and monitoring of the site, maintenance of barriers to access to radioactive materials left on the site, and prevention of activities on the site which might impair these barriers).

An evaluation of the radiation hazards incident to the production, use, release, disposal or presence of radioactive materials or other sources of radiation under a specific set of conditions.

A metric ton, or $1000 \mathrm{~kg}$, or $2204.6 \mathrm{lb}$.

A self-propelled, air operated drill rig with an extendible boom capable of drilling 60 foot deep vertical holes in concrete and lifting the boxed material back to the surface.

Elements with atomic number ( $Z$ number) greater than 92 .

Any waste material measured or assumed to contain more than a specified concentration (e.g., presently proposed as 10 nanocuries of alpha emitters per gram of waste) of transuranic elements.

Area within an exclusion area where radioactive solid waste is stored by burial.

Equipment and materials (from nuclear operations) that are radioactive and for which there is no further use.

A penetrating form of electromagnetic radiation emitted either when the inner orbital electrons of an excited atom return to their normal state (characteristic $X$ rays) or when a metal target is bombarded with high speed electrons. $X$ rays are always non-nuclear in origin; i.e., they originate external to the nucleus of the atom. 


\section{REFERENCES}

1. R. W. Johnson, Capital Budgeting, Wadsworth Publishing Co. Inc., Belmont, CA pp 48, 1970.

2. E. L. Grant, W. G. Ireson and R. S. Leavenworth, Principles of Engineering Economy, 6th edition, The Ronald Press Co., New York, 1976.

\section{GENERAL REFERENCES}

American National Standard Glossary of Terms In Nuclear Science and Technology. Published by the American Nuclear Society, Hinsdale, IL, 60527, 1976.

McGraw-Hill Dictionary of Scientific and Technical Terms. McGraw-Hi11, Inc., 1976.

Radiological Health Handbook. Public Health Service Publication No. 2016, U.S. Government Printing Office, Washington, DC 20402, Revised Edition, January 1970.

Glossary of Nuclear Industry Terms. Prepared by Standards and Specifications Atomic Power Equipment Department, General Electric Company, San Jose, CA, September 1969. 